WSRC-TR-2003-00205, REVISION 0

SRT-RPP-2003-00086, REVISION 0

\title{
COMPOSITING AND CHARACTERIZATION OF SAMPLES FROM HANFORD TANK 241-AY-102/C-106
}

OCTOBER 2003

\section{SAVANNAH RIVER TECHNOLOGY CENTER}

Westinghouse Savannah River Company Savannah River Site Aiken, SC 29808

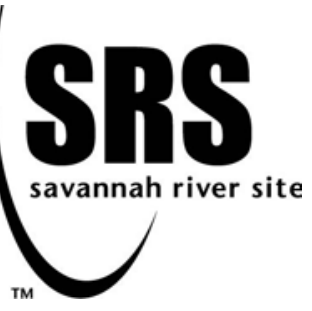


This document was prepared in conjunction with work accomplished under Contract No. DE-AC09-96SR18500 with the U. S. Department of Energy.

\section{DISCLAIMER}

This report was prepared as an account of work sponsored by an agency of the United States Government. Neither the United States Government nor any agency thereof, nor any of their employees, makes any warranty, express or implied, or assumes any legal liability or responsibility for the accuracy, completeness, or usefulness of any information, apparatus, product or process disclosed, or represents that its use would not infringe privately owned rights. Reference herein to any specific commercial product, process or service by trade name, trademark, manufacturer, or otherwise does not necessarily constitute or imply its endorsement, recommendation, or favoring by the United States Government or any agency thereof. The views and opinions of authors expressed herein do not necessarily state or reflect those of the United States Government or any agency thereof.

This report has been reproduced directly from the best available copy.

Available for sale to the public, in paper, from: U.S. Department of Commerce, National Technical Information Service, 5285 Port Royal Road, Springfield, VA 22161, phone: (800) 553-6847, fax: (703) 605-6900

email: orders@ntis.fedworld.gov

online ordering: http://www.ntis.gov/help/index.asp

Available electronically at http://www.osti.gov/bridge

Available for a processing fee to U.S. Department of Energy and its contractors, in paper, from: U.S. Department of Energy, Office of Scientific and Technical Information, P.O. Box 62, Oak Ridge, TN 37831-0062,

phone: (865)576-8401,

fax: (865)576-5728

email: $\underline{\text { reports@ adonis.osti.gov }}$ 
WSRC-TR-2003-00205, REVISION 0

SRT-RPP-2003-00086, REVISION 0

Key Words:

Sludge Composition

Supernatant Composition

Sample Analysis

Envelope D

Retention:

Permanent

Key WTP R\&T References:

Test Specification 24590-WTP-TSP-RT-01-014, Rev 0

Task Plan WSRC-TR-2001-00601, Rev. 0

Test Exceptions

24590-WTP-TEF-RT-02-022

24590-WTP-TEF-RT-02-031

24590-WTP-TEF-RT-02-047

24590-WTP-TEF-RT-03-048

\section{COMPOSITING AND CHARACTERIZATION OF SAMPLES FROM HANFORD TANK 241-AY-102/C-106}

\section{J. Coleman, SRTC/ADS \\ M. S. Hay, SRTC/WPT \\ K. B. Martin, SRTC/WPT}

OCTOBER 2003

Westinghouse Savannah River Company

Savannah River Site

Aiken, SC 29808

Prepared for the U.S. Department of Energy Under Contract Number DE-AC09-96SR18500

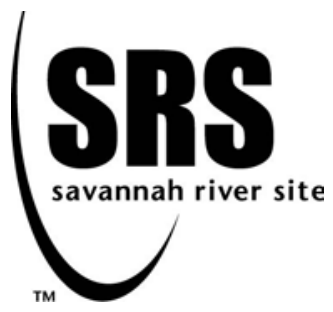




\section{TABLE OF CONTENTS}

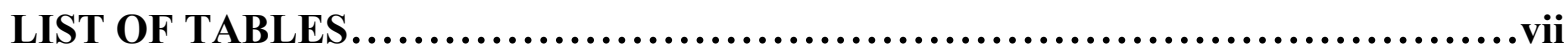

LIST OF ACRONYMS.....................................................

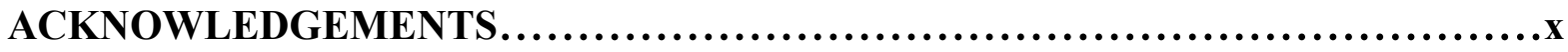

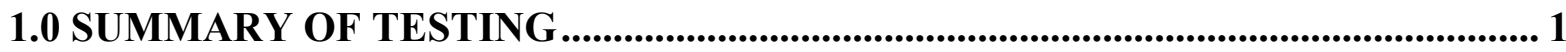

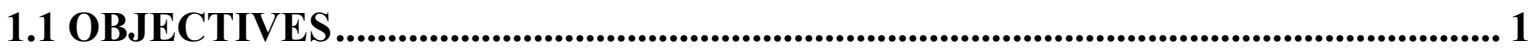

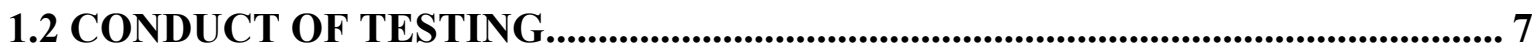

1.3 RESULTS AND PERFORMANCE AGAINST OBJECTIVES ................................. 7

1.4 QUALITY REQUIREMENTS................................................................................ 7

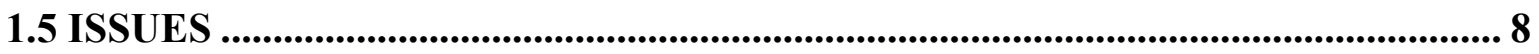

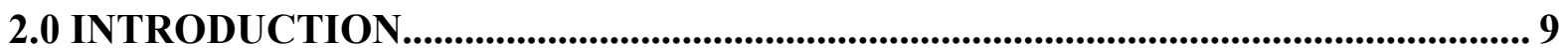

2.1 GENERAL DISCUSSION OF DATA TABLES .......................................................... 10

3.0 SAMPLE RECEIVING AND COMPOSITING - VISUAL DESCRIPTION OF THE

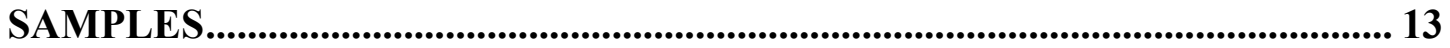

3.1 MEASURED WEIGHT OF AY-102/C-106 SLUDGE IN THE NINE GLASS JARS

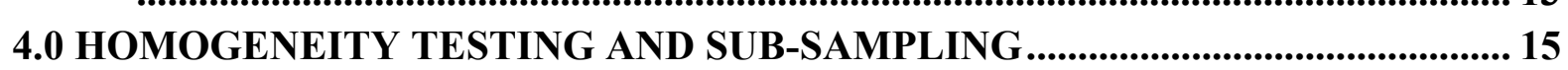

4.1 INITIAL HOMOGENEITY TEST............................................................................ 15

4.2 SECOND HOMOGENEOUS TEST............................................................................ 16

5.0 PHYSICAL PROPERTY MEASUREMENTS OF AY-102/C-106 SLUDGE .......... 19

6.0 CHEMICAL AND RADIONUCLIDE ANALYSIS OF THE SUPERNATANT

FRACTION FROM AY-102/C-106.......................................................................... 25

6.1 SUPERNATANT PRETREATMENT PRIOR TO ANALYSES ............................. 25

6.2 CHEMICAL ANALYSES OF THE SUPERNATANT FRACTION FROM AY-

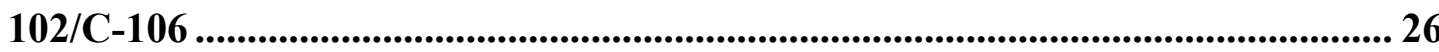

6.3 CHEMICAL COMPOSITION OF AS-RECEIVED AY-102/C-106 FILTERED

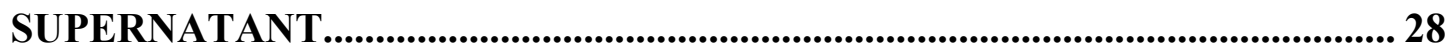

6.4 DISCUSSION OF QC FLAGS FOR TABLE 6-1 ...................................................... 32

6.5 RADIONUCLIDE ANALYSES OF THE AY-102/C-106 FILTERED

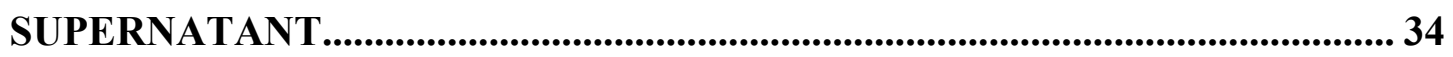

6.5.1 Determinations of ${ }^{3} \mathrm{H}$ in AY-102/C-106 Filtered Supernatant ............................. 35

6.5.2 Determinations of ${ }^{14} \mathrm{C}$ in $\mathrm{AY}-102 / \mathrm{C}-106$ Filtered Supernatant ............................36

6.5.3 Determinations of ${ }^{60} \mathrm{Co}$ in AY-102/C-106 Filtered Supernatant......................... 37

6.5.4 Determinations of ${ }^{79} \mathrm{Se}$ in AY-102/C-106 Filtered Supernatant.......................... 37

6.5.5 Determinations of ${ }^{90} \mathrm{Sr}$ in $\mathrm{AY}-102 / \mathrm{C}-106$ Filtered Supernatant.......................... 38

6.5.6 Determinations of ${ }^{99} \mathrm{Tc}$ (Total) in AY-102/C-106 Filtered Supernatant.............39

6.5.7 Determinations of ${ }^{99} \mathrm{Tc}$ (as the Pertechnetate Ion) in AY-102/C-106 Filtered Supernatant.

6.5.8 Determinations of ${ }^{125} \mathrm{Sb}$ in $\mathrm{AY}-102 / \mathrm{C}-106$ Filtered Supernatant ........................ 40

6.5.9 Determinations of ${ }^{126} \mathrm{Sb}+{ }^{126} \mathrm{Sn}$ in $\mathrm{AY}-102 / \mathrm{C}-106$ Filtered................................ 41

6.5.10 Determinations of ${ }^{129} I$ in AY-102/C-106 Filtered Supernatant........................ 42 
WSRC-TR-2003-00205, REVISION 0

SRT-RPP-2003-00086, REVISION 0

6.5.11 Determinations of ${ }^{137} \mathrm{Cs}$ in AY-102/C-106 Filtered Supernatant . 43

6.5.12 Determinations of ${ }^{154} \mathrm{Eu},{ }^{155} \mathrm{Eu},{ }^{231} \mathrm{~Pa}$ in AY-102/C-106 Filtered Supernatant43

6.5.13 Determinations of ${ }^{238} \mathrm{Pu},{ }^{239-240} \mathrm{Pu},{ }^{241} \mathrm{Pu}$ in $\mathrm{AY}-102 / \mathrm{C}-106$ Filtered Supernatant 44

6.5.14 Determinations of ${ }^{241} \mathrm{Am},{ }^{243} \mathrm{Am},{ }^{242} \mathrm{Cm},{ }^{243 / 244} \mathrm{Cm}$ in AY-102/C-106 Filtered Supernatant. 45

6.5.15 Total Alpha Determinations of the AY-102/C-106 Filtered Supernatant...... 46

6.5.16 Sum of Transuranic Isotopic Measurements in AY-102/C-106 Filtered

Supernatant.................................................................................................46

6.6 DISCUSSION OF THE QC FLAGS FOR TABLE $6-4$......................................... 49

6.7 COMPARISON OF MEASURED CHEMICAL ANALYTES IN AY-102/C-106

FILTERED SUPERNATANT VS. SPECIFICATION 7 FOR ENVELOPE A, B,

AND C LOW-ACTIVITY WASTE

51

6.8 COMPARISON OF MEASURED RADIONUCLIDES AY-102/C-106 FILTERED

SUPERNATANT FRACTION VERSUS SPECIFICATION 7 FOR ENVELOPE

A, B, AND C LOW-ACTIVITY WASTE. 55

7.0 CHEMICAL AND RADIONUCLIDE ANALYSIS OF THE SOLID FRACTION

FROM AY-102/C-106 .............................................................................................. 57

7.1 SOLIDS FRACTION PRETREATMENT PRIOR TO ANALYSES .................... 57

7.1.1 Warm Water Leach .......................................................................................... 57

7.1.2 Hot Aqua Regia Digestion ...........................................................................58

7.1.3 KOH/KNO $\mathrm{KN}_{3}$ Fusion ................................................................................... 59

7.1.4 Hot HF-HNO $\mathrm{H}_{3}-\mathrm{HCl}-\mathrm{H}_{3} \mathrm{BO}_{3}$ Digestion .........................................................59

7.2 CHEMICAL ANALYSES OF THE SOLIDS FRACTION FROM AY-102/C-10660

7.3 ANION, TIC/TOC, AMMONIA ANALYSES OF THE SOLIDS FRACTION

FROM AY-102/C-106

7.4 ANION, TIC/TOC, AND AMMONIA ANALYSES OF THE SOLIDS FRACTION FROM AY-102/C-106 ON BOTH WET SOLIDS AND DRY SOLIDS BASIS.. 64

7.5 DISCUSSION OF QC FLAGS OF THE SOLIDS FRACTION FROM AY-102/C-

106 65

7.6 ELEMENTAL ANALYSES OF THE AY-102/C-106 SOLIDS FRACTION FOLLOWING DIGESTION WITH HOT AQUA REGIA 66

7.7 ELEMENTAL COMPOSITION OF THE AS-RECEIVED AY-102/C-106 SOLIDS FOLLOWING DIGESTION WITH HOT AQUA REGIA_ON BOTH WET SOLIDS AND DRY SOLIDS BASIS 69

7.8 QC FLAGS FOR ELEMENTAL ANALYSES OF THE 102/C-106 SOLIDS FRACTION FOLLOWING DIGESTION WITH HOT AQUA REGIA............ 73

7.9 ELEMENTAL ANALYSES OF THE AY-102/C-106 SOLIDS FRACTION FOLLOWING DIGESTION WITH KOH/KNO 3 FUSION 74

7.10 ELEMENTAL COMPOSITION OF THE AS-RECEIVED AY-102/C-106 SOLIDS

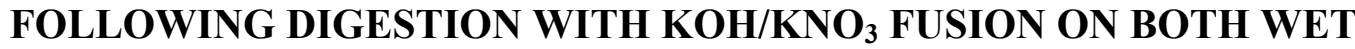
SOLIDS AND DRY SOLIDS BASIS 77

7.11 DISCUSSION OF QC FLAGS FOR TABLE 7-8 81 
7.12 ELEMENTAL ANALYSES ON THE AY-102/C-106 SOLIDS FRACTION FOLLOWING DIGESTION WITH HOT HF-HNO $-\mathrm{HCL}_{3}-\mathrm{H}_{3} \mathrm{BO}_{3}$

7.13 ELEMENTAL COMPOSITION OF THE AS-RECEIVED AY-102/C-106 SOLIDS FOLLOWING DIGESTION WITH HOT HF-HNO ${ }_{3}-\mathrm{HCL}_{-} \mathrm{H}_{3} \mathrm{BO}_{3} \mathrm{ON}$ BOTH WET SOLIDS AND DRY SOLIDS BASIS 84

7.14 DISCUSSION OF QC FLAGS FOR TABLE 7-11 ............................................ 85

7.15 COMPARISON OF ELEMENTAL ANALYSES OF THE AY-102/C-106 SOLIDS FRACTION FROM THE THREE DIGESTION METHODS USED. 86

7.16 ELEMENTAL COMPOSITION OF AY-102/C-106 SOLID FRACTION BASED ON SELECTION OF PREFERRED DIGESTION METHOD FOR EACH ELEMENT.

7.17 RADIONUCLIDE ANALYSES OF THE AY-102/C-106 SOLIDS FRACTION 94

7.17.1 Determinations of ${ }^{3} \mathrm{H}$ in $\mathrm{AY}-102 / \mathrm{C}-106$ Solids Fraction 95

7.17.2 Determinations of ${ }^{14} \mathrm{C}$ in $\mathrm{AY}-102 / \mathrm{C}-106$ Solids Fraction .................................. 96

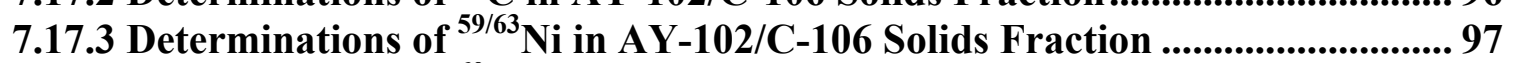

7.17.4 Determinations of ${ }^{60} \mathrm{Co}$ in $\mathrm{AY}-102 / \mathrm{C}-106$ Solids Fraction..............................98

7.17.5 Determinations of ${ }^{79} \mathrm{Se}$ in AY-102/C-106 Solids Fraction................................. 99

7.17.6 Determinations of ${ }^{90} \mathrm{Sr}$ in AY-102/C-106 Solids Fraction.............................. 100

7.17.7 Determinations of ${ }^{99} \mathrm{Tc}$ (Total) in AY-102/C-106 Solids Fraction.................. 101

7.17.8 Determinations of ${ }^{125} \mathrm{Sb},{ }^{126} \mathrm{Sb}-{ }^{126} \mathrm{Sn}$ in AY-102/C-106 Solids Fraction ........ 102

7.17.9 Determinations of ${ }^{129} \mathrm{I}$ in AY-102/C-106 Solids Fraction ................................ 102

7.17.10 Determinations of ${ }^{137} \mathrm{Cs}$ in $\mathrm{AY}-102 / \mathrm{C}-106$ Solids Fraction ............................. 104

7.17.11 Determinations of ${ }^{151} \mathrm{Sm}$ in AY-102/C-106 Solids Fraction ........................... 104

7.17.12 Determinations of ${ }^{152} \mathrm{Eu},{ }^{154} \mathrm{Eu},{ }^{155} \mathrm{Eu},{ }^{231} \mathrm{~Pa}$ in AY-102/C-106 Solids Fraction

7.17.13 Determinations of ${ }^{238} \mathrm{Pu},{ }^{239-240} \mathrm{Pu},{ }^{241} \mathrm{Pu}$ in $\mathrm{AY}-102 / \mathrm{C}-106$ Solids Fraction 106

7.17.14 Determinations of ${ }^{241} \mathrm{Am},{ }^{243} \mathrm{Am},{ }^{242} \mathrm{Cm},{ }^{243 / 244} \mathrm{Cm}$ in AY-102/C-106 Solids Fraction ......................................................................................................... 107

7.17.15 Total Beta Determinations of the AY-102/C-106 Solids Fraction............... 108

7.17.16 Total Alpha Determinations of the AY-102/C-106 Solids Fraction ............ 108

7.17.17 Sum of Transuranic Isotopic Measurements in AY-102/C-106 Solid Fraction 109

7.18 RADIONUCLIDE COMPOSITION OF AY-102/C-106 SOLIDS ON BOTH WET SOLIDS FRACTION AND DRY SOLIDS BASIS ......................................... 112

7.19 QC FLAGS FOR RADIONUCLIDE MEASUREMENTS ON THE AY-102/C-106 114

8.0 COMPARISON OF MEASURED ANALYTES IN UNWASHED AY-102/C-106 SOLIDS TO SPECIFICATION 8, HIGH-LEVEL WASTE ENVELOPE IN WTP CONTRACT. 117

9.0 COMPARISON OF INHIBITED WATER LEACH, PLANT LEACH PROCEDURE, AND SPECIFICATION 12 LEACH PROCEDURE......................................... 125

9.1 0.01 M NaOH WASH OF AY-102/C-106 SOLID FRACTION .......................... 126

9.2 ELEMENTAL AND ANION ANALYSIS OF THE WASH SOLUTIONS AFTER 4 TRIALS OF THE 0.01 M NaOH WASH PROCEDURE 127 
9.3 ELEMENTAL ANALYSIS OF THE RESIDUAL WET SOLIDS AFTER 4 TRIALS OF THE 0.01 M NaOH WASH PROCEDURE

9.4 PLANT LEACH PROCEDURE OF AY-102/C-106 SOLID FRACTION ........... 131

9.5 PLANT LEACH PROCEDURE WASH AND LEACH SOLUTIONS.................. 134

9.6 ELEMENTAL ANALYSIS OF THE RESIDUAL WET SOLIDS AFTER THE PLANT LEACH PROCEDURE 136

9.7 SPECIFICATION 12 LEACH PROCEDURE ........................................................ 138

9.8 SPECIFICATION 12 LEACH PROCEDURE WASH AND LEACH SOLUTIONS 139

9.9 ELEMENTAL ANALYSIS OF THE RESIDUAL SOLIDS AFTER THE SPECIFICATION 12 LEACH PROCEDURE 141

9.10 COMPARISON OF ELEMENTAL ANALYSIS OF THE UNWASHED WET AY-102/C-106 SOLIDS WITH THE RESIDUAL WET SOLIDS AFTER THREE PRETREATMENT PROCEDURES 143

9.11 SUMMARY OF RESULTS OF WASH/LEACH PROCEDURE TESTS ......... 145 APPENDIX A - TANK AY-102 CORE SAMPLES. 147

APPENDIX B - AY-102 “AS-RECEIVED” SHIELDED CELLS RHEOLOGY RESULTS 151 APPENDIX C - PARTICLE SIZE DETERMINATIONS OF AY-102/C-106 DRIED SLUDGE 163 APPENDIX D - CALORIMETRY MEASUREMENTS OF HEAT CAPACITY OF DRY AY-102/C-106 SOLID FRACTION 167 


\section{LIST OF TABLES}

Table 3-1. Comparison of SRTC Measured Net Weight of AY-102/C-106 Sludge vs. Hanford

Reported Net Weight............................................................................................. 14

Table 4-1. Results of the Initial Homogeneity Test for As-Received AY-102/C-106 ............. 17

Table 4-2. Results of the Second Homogeneity Test for As-Received AY-102/C-106 …....... 17

Table 5-1. Physical Properties of AY-102/C-106 .............................................................. 23

Table 6-1. Instrumental Analysis Methods Used For Analyzing AY-102/C-106 Supernatant

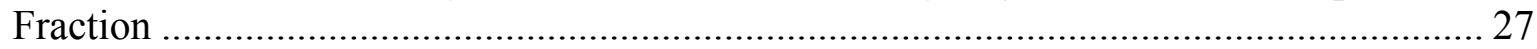

Table 6-2. Chemical Composition of the AY-102/C-106 Filtered Supernatant ...................... 29

Table 6-3. QC Flags for Chemical Composition Measurements on the Filtered Supernatant

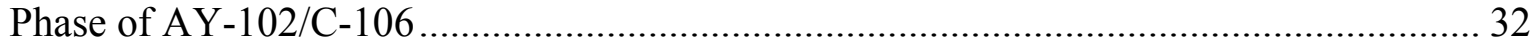

Table 6-4. Radionuclide Composition of AY-102/C-106 Filtered Supernatant ...................... 47

Table 6-5. QC Flags for Radionuclide Measurements on the Filtered Supernatant Phase of

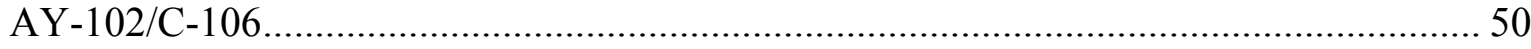

Table 6-6. Comparison of Measured Chemical Analyte/Na Molar Ratios in AY-102/C-106

Supernatant Fraction vs. Maximum Chemical Analyte/Na Molar Ratios .......................... 52

Table 6-7. Comparison of Measured Chemical Analyte/Na Molar Ratios in AY-102/C-106

Supernatant Fraction vs. Maximum Chemical Analyte/Na Molar Ratios .......................... 53

Table 6-8. Comparison of Measured Chemical Analyte/Na Molar Ratios in AY-102/C-106

Supernatant Fraction vs. Maximum Chemical Analyte/Na Molar Ratios ......................... 54

Table 6-9. Comparison of Measured Becquerels of Radionuclide per Mole of Na in

Supernatant Fraction vs. Maximum Becquerels of Radionuclide per Mole of Na ............. 55

Table 6-10. Comparison of Measured Becquerels of Radionuclide per Mole of Na in

Supernatant Fraction vs. Maximum Becquerels of Radionuclide per Mole of Na ............ 56

Table 6-11. Comparison of Measured Becquerels of Radionuclide per Mole of Na in

Supernatant Fraction vs. Maximum Becquerels of Radionuclide per Mole of Na .............56

Table 7-1. Instrumental Analysis Methods Used for Analyzing AY-102/C-106 Solid Fraction

Table 7-2. Anion, TIC/TOC, and Ammonia Composition of the As-Received AY-102/C-106 Solids Fraction Following a Warm Water Leach to Separate the Water-Soluble Analytes from the Solids and Dilution To $50 \mathrm{~mL}$

Table 7-3. Anion, TIC/TOC, and Ammonia Composition of the As-Received AY-102/C-106

Solids Following a Warm Water Leach and Dilution to $50 \mathrm{~mL}$ on Both Wet Solids Basis

and Dry Solids Basis

Table 7-4. QC Flags for Anion, TIC/TOC, and Ammonia Measurements on the Solid Fraction of AY-102/C-106

Table 7-5. Elemental Composition of the As-Received AY-102/C-106 Solids Following

Digestion with Hot Aqua Regia 66

Table 7-6. Elemental Composition of AY-102/C-106 Solids Fraction Following Digestion with Hot Aqua Regia on Both Wet Solids Basis and Dry Solids Basis .............................. 70

Table 7-7. QC Flags for Elemental Analyses on the AY-102/C-106 Solids Fraction Following

Digestion with Hot Aqua Regia .................................................................................... 73

Table 7-8. Elemental Composition of the As-received AY-102/C-106 Solids Following

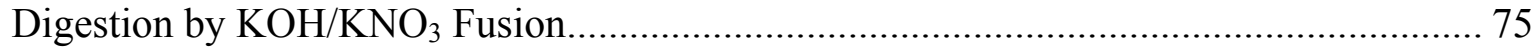


Table 7-9. Elemental Composition of AY-102/C-106 Solids Fraction Following Digestion with $\mathrm{KOH} / \mathrm{KNO}_{3}$ on Both Wet Solids Basis and Dry Solids Basis

Table 7-10. QC Flags for Elemental Analyses on the AY-102/C-106 Solids Fraction Following Digestion with $\mathrm{KOH} / \mathrm{KNO}_{3}$

Table 7-11. Elemental Composition of the As-Received AY-102/C-106 Solids Following Digestion with Hot $\mathrm{HF}-\mathrm{HNO}_{3}-\mathrm{HCl}-\mathrm{H}_{3} \mathrm{BO}_{3}$

Table 7-12. Elemental Composition of AY-102/C-106 Solids Fraction Following Digestion with Hot $\mathrm{HF}-\mathrm{HNO}_{3}-\mathrm{HCl}-\mathrm{H}_{3} \mathrm{BO}_{3}$ on Both Wet Solids Basis and Dry Solids Basis ........... 84

Table 7-13. QC flags for Elemental Analyses on the AY-102/C-106 Solids Fraction Following Digestion with $\mathrm{Hot} \mathrm{HF}-\mathrm{HNO}_{3}-\mathrm{HCl}-\mathrm{H}_{3} \mathrm{BO}_{3}$

Table 7-14. Comparison of Elemental Analyses of AY-102/C-106 Solids Fraction from the Three Digestion Methods Used: Hot Aqua Regia, KOH Fusion, and Hot $\mathrm{HF}-\mathrm{HNO}_{3}-\mathrm{HCl}-$ $\mathrm{H}_{3} \mathrm{BO}_{3}$

Table 7-15. Elemental Composition of AY-102/C-106 Solids Fraction Based on Selection of Preferred Digestion Method for Each Element on Both Wet Solids Basis and Dry Solids Basis

Table 7-16. Comparison of Elemental Analysis of the Analytical Reference Glass-1

Following Digestion with Hot Aqua Regia or $\mathrm{KOH} / \mathrm{KNO}_{3}$ Fusion.

Table 7-17. Radionuclide Composition of AY-102/C-106 Solids Fraction

Table 7-18. Radionuclide Composition of AY-102/C-106 Solids Fraction on Both Wet Solids Basis and Dry Solids Basis

Table 7-19. QC flags for Radionuclide Measurements on the AY-102/C-106 Solids Fraction

Table 8-1. Comparison of Measured Concentration of Non-Volatile Elements in AY-102/C106 Unwashed Solids vs. Maximum Concentration Per Hanford Specification 8 ........... 118

Table 8-2. Comparison of Measured Concentration of Volatile Components in AY-102/C-

106 Unwashed Solids vs. Maximum Concentration Per Hanford Specification 8 .......... 120

Table 8-3. Comparison of Measured Concentration of Radionuclides in AY-102/C-106

Unwashed Solids vs. Maximum Concentration Per Hanford Specification 8 ................ 121

Table 8-4. Comparison of Measure Concentration of Non-Volatile Elements in AY-102/C-

106 Unwashed Solids vs. Maximum Recommended Concentration Per Hanford

Specification 8

Table 9-1. Weights of Liquid and Solid Fractions in Inhibited Water Wash

Table 9-2. Elemental and Anion Analysis of the Wash Solutions after 4 Trials of the $0.01 \mathrm{M}$

$\mathrm{NaOH}$ Wash Procedure

Table 9-3. Elemental Analysis of the Residual Wet Solids After 4 Trials of the Inhibited

Water Wash Procedure

Table 9-4. Weights of Residual Solids and Wash Solutions in the Plant Leach Procedure

Performed on AY-102/C-106 Solid Fraction ................................................................ 133

Table 9-5. Plant Leach Procedure Wash and Leach Solutions .......................................... 135

Table 9-6. Elemental Analysis of the Residual Wet Solids after the Plant Leach Procedure 137

Table 9-7. Weights of Residual Solids and Wash Solutions in the Specification 12 Leach

Procedure Performed on AY-102/C-106 Solids Fraction .......................................... 139

Table 9-8. Elemental and Anion Composition of the Five $0.01 \mathrm{M} \mathrm{NaOH}$ Washes and the Hot

Caustic Leach Solution of the Specification 12 Leach Procedure 
WSRC-TR-2003-00205, REVISION 0

SRT-RPP-2003-00086, REVISION 0

Table 9-9. Elemental Analysis of the Residual Wet Solids after the Specification 12 Leach

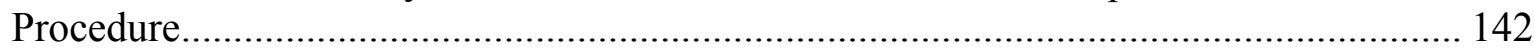

Table 9-10. Comparison of Elemental Analysis of the Unwashed Wet AY-102/C-106 Solids with the Residual Wet Solids after Three Pretreatment Procedures 0.01 M NaOH Wash

Procedure; Plant Leach Procedure; and Specification 12 Leach Procedure 144

\section{LIST OF ACRONYMS}

Bechtel National, Inc./Washington Group International (BNI/WGI)

Laboratory Control Standard (LCS)

Matrix Spike (MS)

Quality Control Acceptance Criteria (QCAC)

Relative Standard Deviation (RSD)

River Protection Project-Waste Treatment Plant (RPP-WTP)

Savannah River Technology Center (SRTC)

Total Inorganic Carbon (TIC) 


\section{ACKNOWLEDGEMENTS}

The report authors gratefully acknowledge the following contributors to the AY-102/

C-106 characterization effort for their excellent work:

Martha Holmes, Dennis Lewis, Monica Jenkins

June Hart, Frank Pennebaker, Loretta Farrow

Mira Malek, Bill Boyce, Frank Pennebaker, Pam

Waller

David DiPrete, Ceci DiPrete, Teresa Eddy, Gina

Robbins, Robin Wainwright, Dan Walker,

Beverly Adams, Yvonne Tilley, Kathy Smith

Robert Ray, Thomasina Robinson

Wilson Smith

Fernando Fondeur

Mike Whitaker, Sharon Gleaton

Bob Hochel, John Young, Amy Ekechukwu

Erich Hansen and Terri Fellinger

Jon Kuhns, Leigh Brown, Joe Spears, Marti

Finney, Beverly Burch, Angela Bowman

Damon Click

Mimi Jones

Aruna Arakali, Keith Abel
Shielded Cell Operations

ICP-AES Analyses

ICP-MS Analyses

Radiochemical Analyses

Ion Chromatography Analyses

Particle Size Analyses

Calorimetry Analyses

Atomic Absorption Analyses

Total Organic and Inorganic Carbon Analyses; Potentiometric Titration Analyses

Rheology Measurements

Sample Management

Technical Reviewer

Technical Editor

Hanford Waste Treatment Plant Technical/Editorial Help and Feedback 


\subsection{SUMMARY OF TESTING}

As part of the program to provide waste characterization and pretreatment data to support the Waste Treatment Plant WTP mission to treat Hanford tank waste, a $\sim 3.8$ L sample of waste from Hanford Tank 241-AY-102/C-106 was received at the Savannah River Technology Center (SRTC). The waste sample was characterized to provide feed for pretreatment testing. The characterization data provides a basis for rational development of pretreatment processes, determination of reagent requirements, and development of physical design parameters for the pretreatment plant.

\subsection{OBJECTIVES}

The main objectives of this work as defined by the test specification and approved task plan were to:

- Prepare a composite sample from the multiple samples of AY-102/C-106

- Verify the homogeneity of the composite sample

- Analyze the composite sample for physical properties

- Separate the composite sample into solid and supernatant phases

- Analyze both the supernatant and solid phases for physical, chemical, and radiochemical properties

- Prepare samples and coordinate the determination of selected analytes by BWX Technologies (BWXT)

- Compare analytical measurements of the AY-102/C-106 filtered supernatant phase to the Low-Activity Waste (LAW) feed specifications per Hanford Specification 7 for Envelopes A, B, and C LAW.

- Compare analytical results of the AY-102/C-106 solid fraction to the High-Level Waste (HLW) feed specifications per Hanford Specification 8

- Perform washing and leaching tests on the AY-102/C-106 solids fraction and characterize the residual solids and wash/leach solutions

- Report analytical results

The major goals set forth in the Test Specification (including any Test Exceptions) were met. The amount of sludge provided was insufficient to measure the suite of physical properties on the solid fraction after a 2-3 week settling time and again after 6 months without impacting the Cells Unit Filter (CUF) and Vitrification Programs. The decision was made to perform physical property measurements only on freshly suspended material. The following discussion lists the goals stipulated in the Test Specification and provides a brief narrative of the results. 


\section{- Prepare a composite sample from the multiple samples of AY-102/C-106}

Result: Nine 500-mL jars of 241-AY-102/C-106 tank waste were received at SRTC and combined into an 8-L carboy.

Details are discussed in Section 3.0, with results shown in Table 3-1.

\section{- Verify the homogeneity of the composite sample}

Result: Homogeneity tests were performed by removing 12 sub-samples with a volume of approximately $230 \mathrm{~mL}$ and allowing the solids to settle in $250-\mathrm{mL}$ graduated cylinders. The volume \% settled solids of the 12 sub-samples were used to assess homogeneity of the slurry. The initial homogeneity test indicated that the mixing rate was inadequate to achieve a homogeneous mixture. During the first homogeneity test, one of the graduated cylinders was dropped and broken, spilling the entire contents. The homogeneity test was repeated using the same equipment, but with the mixing rate increased to achieve a strong vortex to the bottom of the carboy. Close agreement in the volume percent settled solids of the 12 sub-samples indicated that a homogeneous mixture was achieved with these mixing conditions. Two of the 12 sub-samples were then combined for characterization and pretreatment studies, two sub-samples were combined for rheology measurements, and two sub-samples were combined for archival purposes. The remaining six subsamples were returned to the carboy, which was then set aside for pretreatment and filtration studies. A portion was set aside for 6 months to check for formation of a third phase (that is, an organic phase). No phases other than the aqueous and solid phases were perceived through the shielded cell window.

Details are discussed in Section 4.0 with results shown in Table 4-1 and Table 4-2.

\section{- Analyze the composite sample for physical properties}

Result: Physical property measurements, including the rheology measurements, were performed in the SRTC shielded cells with no difficulties. No analytical re-work was required in the SRTC shielded cells except for measurements of the calcined solids in the supernatant phase. A second set of three determinations was required to achieve the precision objectives.

Details are discussed in Section 5.0, with results shown in Table 5-1. The rheology measurements are discussed in detail in a separate report by E.K. Hansen and T.L. Fellinger of the Immobilization Technology Section of SRTC (Appendix B of this report). 
Explanatory Note: Work performed versus work scope stipulated in the Test Specification.

The Test Specification in Section 6.2.2.2 and Section 6.2.2.3 stipulates that the solid fraction after settling for 2-3 weeks and 150-180 days, respectively, will be separated from liquid phase by decanting and the entire suite of physical property measurements (including rheology) will be performed. Since a significant fraction of the $460 \mathrm{~mL}$ of as-received slurry designated for analyses was consumed in the physical property measurements, we were concerned that insufficient sludge was available to perform all the analytical measurements on the settled solid phase and still have enough residual sludge to perform the filtration and vitrification studies in the contract. Therefore, physical property measurements were made only on the freshly suspended material. Rheological measurements were made as described in Appendix B.

Enough material was set aside to make physical observations of the settled solids as a function of settling period. No unusual heterogeneous phases were observed in the 2-3 week and 6 month settled solids versus the solids that were observed after 24 hours of settling as part of the homogeneity tests. Moreover, none of the settled solids appeared significantly different than the settled solids in the $500 \mathrm{~mL}$ grab sample bottles from Hanford that were left undisturbed for approximately 9 months in the SRTC shielded cell facility prior to starting analytical work.

\section{- Separate the composite sample into solid and supernatant phases}

Result: A benchtop centrifuge was used to separate the composite sample into solid and supernatant phases. Good precision in the analyses of the supernatant and solid fractions indicated that the phase separation was accomplished without difficulty.

- Analyze both the supernatant and solid phases for physical, chemical, and radiochemical properties

Result: The requested analyses were performed with good overall precision and accuracy. Most determinations met the quality control goals in terms of replicate precision and successful analyses of laboratory control standards and matrix spikes. Those determinations that did not meet the quality control goals were generally only slightly outside the Quality Control Objective (QCO) as set forth in the Task Plan. For most QC flags, we did not repeat analyses if we felt the data quality was reasonable considering the level of analytical complexity, analyte concentration, etc. We also looked at the data quality from the viewpoint of how it would be used. If the analytical quality was adequate for most waste treatment plant process control applications and for waste compliance regulatory purposes, we felt that it was more useful to report the data obtained on the initial set of analyses than to perform multiple sets of analyses. Many of the analytes for which the analyses were flagged for a QC failure were trace components near the detection limit. In most of these cases, the Minimum Reportable Quantities (MRQ) were so low in concentration that failure to meet the MRQ will have minimal consequence for waste processing. 
Physical properties were measured on the as-received slurry. The slurry was then separated into solid and supernatant phases by centrifugation and filtration. Physical properties were then measured on each phase. These measurements, in general, went very smoothly and met the QCO on the first attempt.

A portion of the supernatant fraction was removed from the cells for ion, inorganic and organic carbon, free hydroxide and total alkalinity determinations. Most of these determinations met the QCO. However, the matrix spike QCO failed for nitrite, citrate, acetate, glycolate, and inorganic and total organic carbon. The \% RSD QCO failed for citrate and total organic carbon.

Another portion of the supernatant fraction was heated with nitric acid and hydrogen peroxide in sealed Teflon containers as the sample preparation step prior to elemental and radionuclide determinations. Most of these determinations met the QCO. Determinations that failed to meet the QCO were for $\mathrm{As}, \mathrm{Hg}$, and $\mathrm{Se}$ (matrix spike failure and failure to meet the MRQ), thorium (\% RSD failure), uranium (matrix spike failure), and tungsten (matrix spike failure). Note that even though SRTC had two QCO failures with the $\mathrm{Hg}$ determinations, BWXT met the MRQ (partially because this laboratory analyzed the undiluted, undigested supernatant) and analyzed the matrix spike to meet the QCO. Therefore, the BWXT determinations of $\mathrm{Hg}$ in the supernatant are preferred in this case.

Data quality was in general very good for the radionuclide determinations on the supernatant fraction. Eight radionuclide measurements did not meet the QCO, usually because the low concentrations of the radionuclides manifested themselves as either failure to meet the MRQ $\left({ }^{231} \mathrm{~Pa}\right)$, failure to meet the $15 \%$ RSD precision QCO $\left({ }^{3} \mathrm{H},{ }^{79} \mathrm{Se},{ }^{241} \mathrm{Am}\right.$, ${ }^{243,244} \mathrm{Cm}$ ), or failure to meet the maximum blank level criterion the blank measurement QCO $\left({ }^{241} \mathrm{Am},{ }^{243,244} \mathrm{Cm}\right)$. The \% RSD QCO also was not met for total alpha because of imperfect separation of interfering radionuclides. Uranium isotopic determinations by Inductively Coupled Plasma-Mass Spectrometry had QCO failures for a laboratory control standard $\left({ }^{235} \mathrm{U}\right)$ or a matrix spike $\left({ }^{238} \mathrm{U}\right)$.

The wet solids that remained after centrifugation and decanting off the supernatant phase were treated with four primary sample preparation techniques prior to removing the solutions from the shielded cells for instrumental analysis. Hot aqua regia $(3: 1, \mathrm{v} / \mathrm{v}$, concentrated hydrochloric acid and concentrated nitric acid) in a sealed Teflon pressure vessel was used to dissolve the solids for elemental and radionuclide determinations. Wet solids were also dissolved with a mixture of nitric acid, hydrochloric acid, hydrofluoric acid, and boric acid for elemental determinations. Dried solids were dissolved with a potassium hydroxide fusion for elemental analysis. Ion determinations were obtained on solutions after leaching the solids with warm de-ionized water. Additional specific sample preparation techniques were used in the analysis of ${ }^{14} \mathrm{C},{ }^{59,63} \mathrm{Ni},{ }^{129} \mathrm{I}$, and ${ }^{79} \mathrm{Se}$. 
Most elemental and ion analyses of the solid fraction of AY-102/C-106 met the QCO. The only QC failures in the determinations of any element of significant concentration in the $\mathrm{KOH}$ fusion were for $\mathrm{Na}$. The \% RSD was $8 \%$ versus the QC objective of $3.5 \%$, and the laboratory control standard and matrix spike recoveries were $86 \%$ and $83 \%$, respectively, versus the QC objectives of 90-110\%. However, data obtained for $\mathrm{Na}$ were considered typical for analysis of sludge dissolved in a shielded cell. We also used the hot mixed acid procedure (nitric, hydrofluoric, boric, and hydrochloric acids) to confirm the $\mathrm{Na}$ concentration since this element is important for all aspects of waste processing.

A significant number of the radionuclide determinations of the solid fraction did not meet the QCO. Most QCO failures were for not meeting the precision requirements of $15 \%$ RSD as opposed to serious lapses in laboratory quality control. Many of the QC failures were for RSDs in the range of 15-30\%. Since these determinations included shielded cell digestions, and since the high-level waste matrix required very stringent separation methods to remove the high concentrations of ${ }^{90} \mathrm{Sr}$ and ${ }^{137} \mathrm{Cs}$, the precision of the radionuclide measurements was good.

The supernatant analyses are discussed in Section 6.1 and 6.2 with results shown in Table 6-2 through Table 6-5.

The solid fraction analyses are discussed in Section 7.0 with results shown in Tables 7-2 through Table 7-18.

- Prepare samples and coordinate the determination of selected analytes by BWX Technologies (BWXT)

Result: Samples of both the supernatant fraction and solid fraction of the AY-102 were prepared in the SRTC shielded cells and sent to BWXT for determination of cyanide, mercury, and ammonia. This program was successful with no major problems encountered. Mercury was at a measurable concentration in the solid phase. SRTC and BWXT obtained good agreement on mercury determinations.

BWXT results are discussed in this report and also in "Data Package for AY-102/ C-106," SRT-RPP-2003-00077, D.M. Ferrara and C.J. Coleman, issued April 21, 2003.

- Compare analytical measurements of the AY-102/C-106 filtered supernatant phase to the Low-Activity Waste (LAW) feed specifications per Hanford Specification 7 for Envelope A, Envelope B, and Envelope C LAW.

Result: The ratio of the mole of analyte/mole of sodium in the supernatant was calculated. All analytes were below the maximum for Envelopes A, B, and C LAW in Specification 7 except for total inorganic carbon (as carbonate), which was $123 \%$ of the maximum ratio for all three LAW Envelopes. 
Also, the ratio of the Becquerels of certain radionuclides in the feed specification $/ \mathrm{mole} \mathrm{Na}$ was calculated. The ratio of transuranic (TRU) radionuclides in Becquerels/mole Na exceeded the maximum ratio for Envelopes A and B LAW by about $2 \%$. The ratio of TRU Becquerels/mole Na did not exceed the maximum ratio for Envelope C LAW. All other radionuclides in Becquerels/mole $\mathrm{Na}$ were below the maximum for all three LAW Envelopes.

Details of the comparison of analytical measurements with maximum values for the three LAW Envelopes are discussed in Sections 6.7 and 6.8, with results shown in Table 6-6 through Table 6-11.

- Compare analytical results of the AY-102/C-106 solid fraction to the High-Level Waste (HLW) feed specifications per Hanford Specification 8

Result: The measured concentrations of all 54 analytes were below the maximum permitted as per Hanford HLW feed specifications. Specification 8 also lists 22 elements for which a recommended, but not required, maximum concentration is listed. The measured $\mathrm{Na}$ value slightly exceeded the recommended maximum concentration $(115 \%$ of the recommended maximum).

Details are discussed in Section 8.0 with results shown in Table 8.1 through Table 8.4.

- Perform washing and leaching tests on the AY-102/C-106 solids fraction and characterize the residual solids and wash/leach solutions

Result: The composition of the unwashed AY-102 solids was compared with the composition of the residual solids after washing with $0.01 \mathrm{M} \mathrm{NaOH}$, performing the Plant Leach Procedure, and performing the Specification 12 Leach Procedure. The major conclusions were:

1. The Plant Leach Procedure and Specification 12 Leach Procedure both significantly reduce the amount of $\mathrm{Al}$ in the washed AY-102/C-106 solid fraction compared with Fe. The Al reduction resulting from the wash/leach procedures was manifested by changes in the $\mathrm{Fe} / \mathrm{Al}$ elemental ratio:

$$
\begin{array}{ll}
\text { Unwashed AY-102/C-106 sludge; } & \mathrm{Fe} / \mathrm{Al}=2.24 \\
\text { Plant Leach Procedure; } & \mathrm{Fe} / \mathrm{Al}=3.96 \\
\text { Specification } 12 \text { Leach Procedure; } & \mathrm{Fe} / \mathrm{Al}=3.73
\end{array}
$$

Since the Plant Leach Procedure and Specification 12 Leach Procedure removed no significant quantity of $\mathrm{Fe}$, the approximate amount of $\mathrm{Al}$ removed from these procedures was $43 \%$ for the Plant Leach Procedure and $40 \%$ for the Specification 12 Leach Procedure. 
2. The Plant Leach Procedure and the Specification 12 Leach Procedure produced essentially the same solid residue as measured by elemental analysis.

3. The Specification 12 Leach Procedure is much easier to perform in a shielded cell environment.

4. Analyses of the wash solutions from all three wash/leach procedures were consistent in general with expectations based on simple dilutions of the interstitial supernatant in the unwashed AY-102/C-106 solid fraction.

Details are discussed in Section 9.0 with results shown in Table 9.1 through Table 9.10.

\section{- Report analytical results}

Result: Full analytical results are contained in the tables and narratives in this report.

\subsection{CONDUCT OF TESTING}

All physical property measurements were performed in the SRTC shielded cells. Chemical and radionuclide measurements were made primarily on diluted samples, usually after digesting either the supernatant or solid fraction. The digested samples were then removed from the shielded cells and analyzed with Analytical Development Section approved methods. Most analyses were performed in triplicate so that the $\%$ relative standard deviation of three measurements could be calculated. Blanks were also analyzed to check for crosscontamination (especially important for radionuclide determinations). Laboratory control standards and matrix spikes were also analyzed concurrently with the samples for most methods. The determinations were then compared with the Data Quality Objectives set forth in the Task Technical and Quality Assurance Plan for this work. Those determinations that did not meet the Data Quality Objectives were flagged in the data tables and the nature of the QC failures were discussed in this report.

\subsection{RESULTS AND PERFORMANCE AGAINST OBJECTIVES}

This information is discussed in Section 1.1.

\subsection{QUALITY REQUIREMENTS}

This work was conducted in accordance with the RPP-WTP-QA requirements specified for work conducted by SRTC as identified in DOE IWP MOSRLE60. SRTC has provided matrices to WTP demonstrating compliance of the SRTC QA program with the requirements specified by WTP. Specific information regarding the compliance of the SRTC QA program with RW-0333P, Revision 10, NQA-1 1989, Part 1, Basic and Supplementary Requirements and NQA-2a 1990, Subpart 2.7 is contained in these matrices. 
This work was also performed according to a specific Task Technical and Quality Assurance Plan for Compositing, Homogenizing, and Characterizing Samples from Hanford 241-AY-102. Authors: C.J. Coleman, M.S. Hay, K.B. Martin; Reference numbers: WSRC-TR-2001-00601, Rev.0, and SRT-RPP-2001-00232, Rev.0. Issue Date: March 15, 2002.

The work was also performed according to an internal analytical study plan: Analytical Study Plan for the Characterization of Hanford High-Level Waste from Tank AY-102/C-106 to Support the River Protection Program; Author: C.J. Coleman; Reference numbers: WSRC-RP2002-00179; Rev.0 and SRT-RPP-2002-00067, Issue Date: March 12, 2002.

\subsection{ISSUES}

None 


\subsection{INTRODUCTION}

The Savannah River Technology Center (SRTC) has been contracted to provide pretreatment development and testing services to support the River Protection Project-Waste Treatment Plant (RPP-WTP) mission to treat Hanford tank waste. As part of the program, SRTC received actual radioactive Hanford tank waste samples to allow characterization of these samples and subsequent testing of the pretreatment processes. The first step in this program entails detailed characterization of the radioactive waste samples. The waste tank samples shall be characterized for physical, chemical, and radionuclide properties for determining that the feed meets the specification requirements, for supporting WTP environmental activities, establishment of the WTP Authorization Basis, for process verification testing, and product qualification. In addition, the characterization of waste tank samples provides a basis for rational development of pretreatment processes, determination of reagent requirements, and development of physical design parameters for the pretreatment plant.

The characterization portion of the SRTC program was conducted under an approved task and quality assurance plan based on a test specification issued by Bechtel National, Inc./ Washington Group International (BNI/WGI). The results and the associated uncertainties presented provide a description of the sample received at SRTC. The highly radioactive nature of the samples adds complexity to the analysis. Sub-sampling, large dilutions, and remote handling potentially add error to the analytical accuracy. Replicate sample analysis, matrix spike and laboratory control standards, and submission of blanks allow some definition of the magnitude of this error. However, the error associated with obtaining small samples from large non-homogenized waste tanks will be significant. Recent experience at SRS indicates a combined sampling and analytical error on the order of $15-20 \%$ associated with obtaining small samples from a well-mixed waste tank.

The data presented in this report documents the physical, chemical, and radiological characterization of a $\sim 3.8 \mathrm{~L}$ sample from Hanford waste tanks AY-102/C-106. The objectives of this work were to:

- Prepare a composite sample from the multiple AY-102/C-106 samples

- Verify the homogeneity of the composite sample

- Analyze the composite sample, including separate sets of analyses on both the supernatant and solid phases, for physical, chemical, and radiological properties

- Compare the determinations of the filtered supernatant phase to the Low-Activity Waste (LAW) feed specifications for Envelopes A, B, and C

- Compare the determinations of the unwashed solid phase to the High-Level Waste (HLW) feed specifications

- Perform the washing and/or caustic leaching experiments with the solid phase to determine if caustic leaching pretreatment would be appropriate for this sludge

- Report analytical results 


\subsection{GENERAL DISCUSSION OF DATA TABLES}

Most data tables show the:

- Analyte including the analytical method used to make the determinations

- Results of each of three replicate analyses

- Average of these three analyses

- Percent relative standard deviation (\% RSD)of the three determinations

- Results of the blank analysis

- Percent recovery of the Laboratory Control Standard (LCS)

- Percent recovery of the matrix spike (MS)

- QC flag, if any

For determinations below the detection limit, a less than symbol $(<)$ is shown along with the detection limit. The detection limit may be slightly different for three replicate analyses because of slight differences in sample size and dilution factors. Our policy is to report the highest detection limit in the column Average Analysis to be conservative.

The QC flags pertain to the various ways that the data failed to meet the QC Objective (QCO) or the Minimum Reportable Quantity (MRQ) as stipulated in the Test Specification. These QC flags are also redundantly listed and briefly explained at the bottom of the tables in recognition that data tables are often separated from the main report. The QC flags are:

\section{- = meets all QC requirements}

A dash is used in the tables to indicate that no QC flag was required.

$\mathbf{U}_{\mathbf{R}}=$ fails \%RSD requirement

The \% RSD of the three analyses did not fall within the QCO. For most analytes, the QCO is $15 \%$ RSD. The QCO range was stipulated in the Test Specification as $3.5 \%$ for Na because of the importance of this element in all phases of waste processing. On the other hand, the QCO range is slightly wider (per the Task Plan) for a few radionuclide measurements that SRTC experience indicates may have more variability.

$\mathbf{U}_{\mathrm{M}}=$ fails min. reportable quantity

The detection limit exceeded the Minimum Reportable Quantity (MRQ).

$\mathbf{U}_{\mathbf{B}}=$ blank exceeds $5 \%$ of sample concentration

The blank analysis exceeds $5 \%$ of the average analysis of the corresponding analyte in the AY-102/C-106 material.

\section{$\mathrm{U}_{\mathrm{L}}=$ fails \% Recovery of LCS}

The percent recovery of the laboratory control standard (LCS) did not fall within the QCO. For most analytes, the QCO for the LCS is $85-115 \%$ of the standard value. However, the QCO range is $90-110 \%$ for $\mathrm{Na}$ and slightly wider for a few radionuclide measurements for the reasons discussed with $U_{R}$. 
$\mathrm{U}_{\mathrm{S}}=$ fails \% Recovery of MS

The percent recovery of the matrix spike did not fall within the QCO. For most analytes, the QCO is $85-115 \%$ recovery of the matrix spike. However, the QCO range is $90-110 \%$ for $\mathrm{Na}$ and slightly wider for a few radionuclide measurements for the reasons discussed with $U_{R}$.

\section{$\mathrm{U}_{\mathrm{O}}=$ Outlier omitted in reported average analysis}

The outlier analysis was omitted in the average of the three analyses. For the purpose of this report, an outlier is defined as a measurement that differs from the average of the other two replicate measurements by at least a factor of five. This QC flag was only invoked for the analysis of ${ }^{129} \mathrm{I}$ in the solid fraction and the Ti determination on the aqua regia digestion of the solid fraction.

\section{N/A - Not Applicable}

Though technically not a QC flag, this acronym is included in the QC flag list. N/A is usually applied when, at the technical discretion of the analytical method custodian, alternatives to laboratory control standards or matrix spikes were used, or when the average analysis and $\%$ RSD could not be computed because of determinations below the detection limit. 
WSRC-TR-2003-00205, REVISION 0 SRT-RPP-2003-00086, REVISION 0

This page intentionally left blank. 


\subsection{SAMPLE RECEIVING AND COMPOSITING - VISUAL DESCRIPTION OF THE SAMPLES}

A total of nine 500-mL glass jars of 241-AY-102/C-106 tank waste were received at SRTC in July 2001. The 500-mL grab samples were obtained from Core Samples 289 and 290 of the 241-AY-102 waste tank in March 2001. (See Appendix A for additional information on sample history.)

Visual inspection at SRTC showed each jar contained a clear liquid phase with approximately $15-20$ volume \% very dark solids on the bottom. No organic layer (a distinct separate phase in the aqueous supernatant phase) was observed in any of the jars.

\subsection{MEASURED WEIGHT OF AY-102/C-106 SLUDGE IN THE NINE GLASS JARS}

The slurries in each of the nine jars were combined into an 8-L polyethylene carboy to create a composite sample. The slurries were passed through a $1 / 8$ " by $1 / 8^{\prime \prime}$ mesh screen set in the mouth of the carboy. Considerable amounts of solids initially were collected on the screen. However, by using the supernatant phase to rinse these solids and by gently tapping the solids with a plastic bottle, all the solids passed through the screen. We judged that the solids that initially did not pass through the screen were an aggregate of friable particles. No evidence of refractory material that would resist breaking up was found.

The jars were weighed before and after emptying to obtain the weight of slurry in each jar at the time of creating the composite sample. Table 3-1 shows the jar and lab IDs taken from each jar, the measured net weight based on the full and empty weight of each jar, and the reported net weight of each jar from the chain of custody documentation (Appendix A). The volume of sample in the carboy after emptying all of the sample jars was $\sim 3.85 \mathrm{~L}$ based on graduations added to the carboy and the measured slurry density $(1.20 \mathrm{~g} / \mathrm{mL})$. The total weight of sample added to the carboy was $4.622 \mathrm{Kg}$, based on the measured net weight of the slurry in each jar. A total difference of $144 \mathrm{~g}$ was found in the reported net weight of sample in the nine jars as measured by Hanford versus the net weight as measured by SRTC. 
Table 3-1. Comparison of SRTC Measured Net Weight of AY-102/C-106 Sludge vs. Hanford Reported Net Weight

\begin{tabular}{|c|c|c|}
\hline & $\begin{array}{c}\text { SRTC } \\
\text { Jar ID }\end{array}$ & $\begin{array}{c}\text { Hanford } \\
\text { Reported Net Wt. (g) }\end{array}$ \\
\hline 18421 & 490.0 & 521.3 \\
\hline 18422 & 510.5 & 531.5 \\
\hline 18423 & 523.5 & 522.8 \\
\hline 18774 & 516.5 & 529.2 \\
\hline 18777 & 516.5 & 534.2 \\
\hline 18780 & 528.0 & 532.7 \\
\hline 18783 & 519.5 & 533.5 \\
\hline 18784 & 505.0 & 526.9 \\
\hline 18785 & 512.5 & 533.9 \\
\hline Total & $\mathbf{4 6 2 2}$ & $\mathbf{4 7 6 6}$ \\
\hline
\end{tabular}




\subsection{HOMOGENEITY TESTING AND SUB-SAMPLING}

The 8-L carboy was equipped with a mechanical stirrer and a steel dip leg (3/8" ID) connected with tubing (3/8" ID) to a peristaltic pump for sampling purposes. The steel dip leg could be raised or lowered to collect sample from any height in the carboy. A homogeneity test was conducted to ensure that the agitation and sampling system could provide representative samples of the slurry. Twelve 230- or 240-mL sub-samples were obtained and collected in graduated cylinders. The sub-samples were obtained from the top, bottom, or midpoint of the original sample height in the 8-L carboy.

After about 7 sub-samples had been removed, the depth of sludge remaining in the carboy was insufficient to continue to adjust the sampling height. Therefore, all subsequent samples were taken at the bottom position. The 12 sub-samples were capped to prevent evaporation and set aside for 24 hours. The volume of settled solids in each of the 12 graduated cylinders was measured and the volume \% settled solids calculated.

As stipulated in the AY-102/C-106 Test Specification, two criteria must be met for the composite batch to be considered homogeneous:

- The standard deviation for the entire volume $\%$ settled solids data set must not exceed $5 \%$.

- The volume \% settled solids data is to be plotted versus the sample collection order. The best-fit line must not show a trend of greater than 5 volume $\%$ over the range.

\subsection{INITIAL HOMOGENEITY TEST}

During the initial homogenization tests, the stirrer ceased just before taking the $8^{\text {th }}$ sample. It was determined that the most likely cause of the cessation of stirring was inadequate mixing which allowed solids to concentrate in the bottom and eventually stop the stirrer. At this point, the stirring speed was increased to provide enough torque to re-suspend the solids and the next five samples were collected to complete the homogeneity test, even though it was clear that the samples were unlikely to be homogeneous.

Table 4-1 shows the results of the initial homogeneity test on the as-received AY-102/C-106 sample. The average volume \% settled solids of the 12 sub-samples was $26 \%$, with $13 \%$ RSD. The best fit line shown in Figure 4-1 also shows a clear trend of increasing volume $\%$ settled solids from 22 volume \% settled solids in the first sample to as high as 31 volume \% settled solids for the last samples. Therefore, the first homogeneity test failed both the standard deviation and the trend tests, indicating that slurry homogeneity had not been achieved.

For the record, one of the graduated cylinders containing $230 \mathrm{ml}$ of slurry was dropped during the first homogeneity test, resulting in sample loss. The sludge in the remaining 11 graduated cylinders was transferred back to the 8-L carboy. 


\subsection{SECOND HOMOGENEOUS TEST}

The second homogeneity test was performed with the stirrer speed increased to near maximum rate to achieve a strong vortex that extended to the bottom of the carboy. Table 4-2 shows that the average volume $\%$ settled solids of the twelve sub-samples was $39 \%$ with a $\%$ RSD of $2 \%$. The much higher volume $\%$ settled solids in the second homogeneity test versus the first test also indicates that the solids were not completely suspended by the stirrer in the first test. The graphical presentation of the data shown in Figure 4-1 also shows no trend of greater than 5 volume \% settled solids for the 12 sub-samples. Therefore, the second homogeneity test passed both of the required tests as stipulated in the Test Specification.

Six of the twelve 230-mL sub-samples were returned to the carboy. Two of the samples were combined and later used for physical, chemical, and radionuclide determinations; two of the sub-samples were combined and used for rheology measurements; and two sub-samples were combined and set aside as the archived sample. The $460 \mathrm{~mL}$ of slurry to be used for analytical work was further divided while being mixed vigorously into 8 sub-samples to guard against a catastrophic spill that would lose or corrupt the entire sample. 
WSRC-TR-2003-00205, REVISION 0 SRT-RPP-2003-00086, REVISION 0

Table 4-1. Results of the Initial Homogeneity Test for As-Received AY-102/C-106

\begin{tabular}{|c|c|c|c|c|}
\hline $\begin{array}{c}\text { Cylinder } \\
\text { No. }\end{array}$ & $\begin{array}{c}\text { Sampling } \\
\text { Height in } \\
\text { Slurry }\end{array}$ & $\begin{array}{c}\text { Volume of Sample } \\
\mathbf{( m L )}\end{array}$ & $\begin{array}{c}\text { Volume of Settled } \\
\text { Solids after } \\
\mathbf{2 4} \text { hrs. (mL) }\end{array}$ & $\begin{array}{c}\text { Volume \% Solids } \\
\text { after Settling for } \\
\mathbf{2 4} \text { hrs. }\end{array}$ \\
\hline 1 & Top & 230 & 50 & 22 \\
\hline 2 & Middle & 230 & 54 & 24 \\
\hline 3 & Bottom & 240 & 55 & 23 \\
\hline 4 & Top & 230 & 54 & 24 \\
\hline 5 & Middle & 230 & 55 & 24 \\
\hline 6 & Bottom & 230 & 58 & 25 \\
\hline 7 & Top & 230 & 58 & 26 \\
\hline 8 & Bottom & 230 & 59 & 28 \\
\hline 9 & Bottom & 230 & 64 & 30 \\
\hline 10 & Bottom & 230 & 70 & 31 \\
\hline 11 & Bottom & 230 & 72 & 30 \\
\hline 12 & Bottom & 230 & 70 & Avg. $=\mathbf{2 6}$ vol.\% \\
\hline
\end{tabular}

Table 4-2. Results of the Second Homogeneity Test for As-Received AY-102/C-106

\begin{tabular}{|c|c|c|c|c|}
\hline $\begin{array}{c}\text { Cylinder } \\
\text { No. }\end{array}$ & $\begin{array}{c}\text { Sampling } \\
\text { Height in } \\
\text { Slurry }\end{array}$ & $\begin{array}{c}\text { Volume of Sample } \\
(\mathbf{m L})\end{array}$ & $\begin{array}{c}\text { Volume of Settled } \\
\text { Solids after } \\
\mathbf{2 4} \text { hrs. (mL) }\end{array}$ & $\begin{array}{c}\text { Volume \% Solids } \\
\text { after Settling for } \\
\mathbf{2 4} \text { hrs. }\end{array}$ \\
\hline 1 & Bottom & 230 & 90 & 39 \\
\hline 2 & Top & 230 & 88 & 38 \\
\hline 3 & Middle & 230 & 88 & 38 \\
\hline 4 & Top & 230 & 88 & 38 \\
\hline 5 & Middle & 230 & 88 & 38 \\
\hline 6 & Bottom & 230 & 88 & 38 \\
\hline 7 & Top & 230 & 90 & 38 \\
\hline 8 & Middle & 230 & 90 & 39 \\
\hline 9 & Bottom & 230 & 90 & 39 \\
\hline 10 & Bottom & 230 & 90 & 40 \\
\hline 11 & Bottom & 230 & 92 & 40 \\
\hline 12 & Bottom & 230 & 92 & Avg. $=\mathbf{3 9}$ vol.\% \\
\hline $\mathbf{9 S D}$ RSD
\end{tabular}




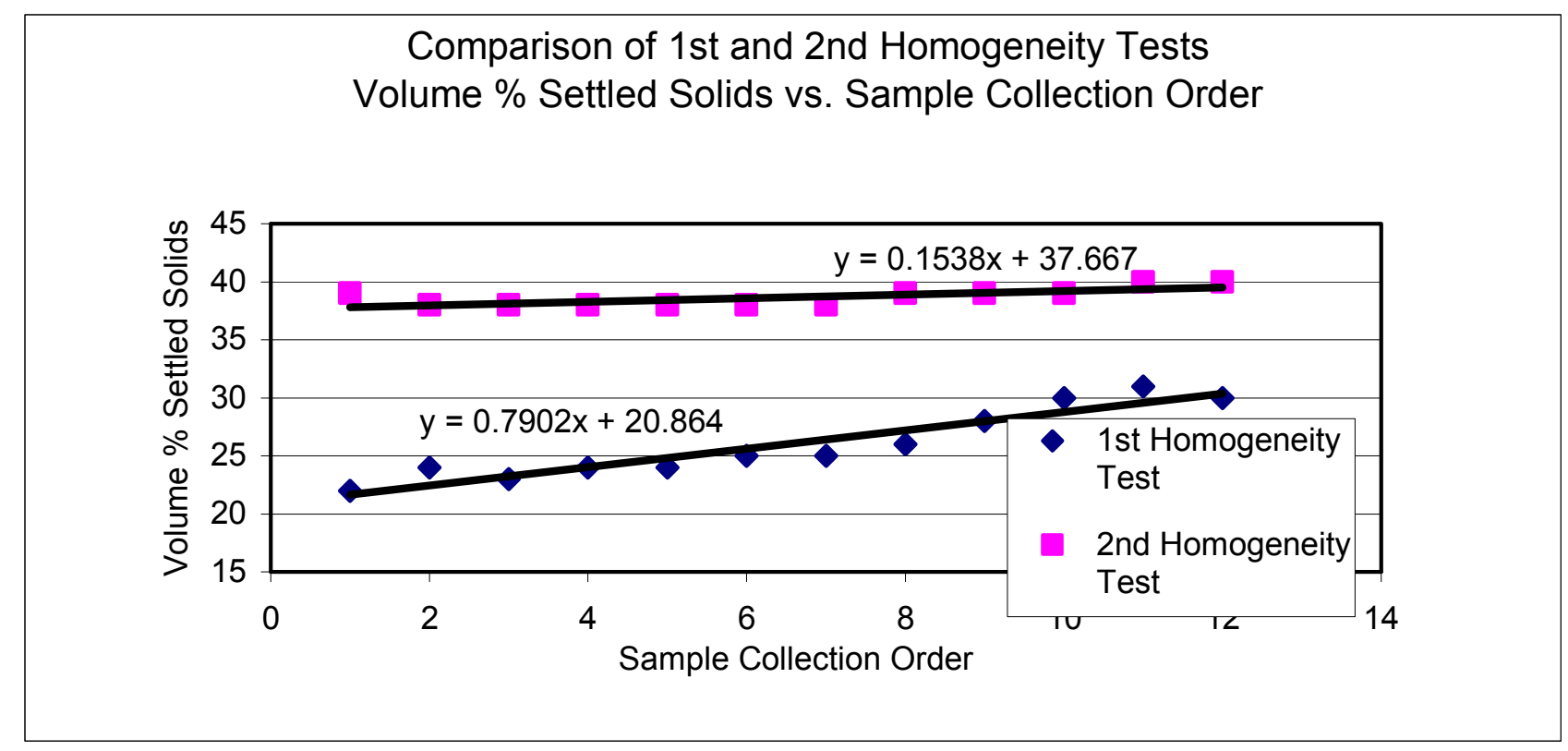

Figure 4-1. Comparison of $1^{\text {st }}$ and $2^{\text {nd }}$ Homogeneity Tests Volume $\%$ Settled Solids vs. Sample Collection Order 


\subsection{PHYSICAL PROPERTY MEASUREMENTS OF AY-102/C-106 SLUDGE}

Explanatory Note: This note is intentionally redundant, also shown in Section 1.1, in recognition that readers usually only focus on the section of interest to them at the time. This note pertains to a significant difference in the physical property measurements made on the AY-102/C-106 material versus the work scope stipulated in the Test Specification.

The Test Specification in Section 6.2.2.2 and Section 6.2.2.3 stipulates that the solid fraction after settling for 2-3 weeks and 150-180 days, respectively, will be separated from liquid phase by decanting and the entire suite of physical property measurements (including rheology) will be performed. Since a significant fraction of the $460 \mathrm{~mL}$ of as-received slurry designated for analyses was consumed in the physical property measurements, we were concerned that there was insufficient sludge to perform all the analytical measurements on the settled solid phase and still have enough residual sludge to perform the filtration and vitrification studies in the contract. Therefore, physical property measurements were made only on the freshly suspended material. Rheological measurements were made as described in Appendix B.

Enough material was set aside to make physical observations of the settled solids as a function of settling period. No unusual heterogeneous phases were observed in the 2-3 week and 6-month settled solids versus the solids that were observed after 24 hours of settling as part of the homogeneity tests. Moreover, none of the settled solids appeared significantly different than the settled solids in the $500 \mathrm{~mL}$ grab sample bottles from Hanford that were left undisturbed for approximately 9 months in the SRTC shielded cell facility prior to starting analytical work.

All physical property measurements, with the exception of particle size, were performed in the SRTC Shielded Cells using written instructions and procedures provided by the principal investigators (documented in the research notebook, WSRC-NB-2001-00200). Rheology measurements were performed by E.K. Hansen and T.L. Fellinger of the Immobilization Technology Section of SRTC. The rheology report and accompanying flow curves comprise Appendix B. Particle size measurements were made by W.M. Smith of the Analytical Development Section of SRTC. Micrographs from which particle sizes were deduced are shown in Appendix C. Calorimetry measurements were performed by F. Fondeur of the Liquid Waste Processing Section of SRTC. Calorimetry curves are shown in Appendix D.

The physical property data are summarized in Table 5-1. These measurements were accomplished smoothly with no QC flags. Rheology, density, and weight \% total solids were measured on the as-received slurry. Remaining measurements were made on either the liquid supernatant phase or the wet solids. Separations were accomplished by using a bench top centrifuge to spin the samples in $10 \mathrm{~mL}$ graduated glass centrifuge tubes at approximately 8000 rpm for one hour. The supernatant fraction was decanted from the solid fraction and passed through a 0.45 -micron porosity paper filter before analysis. The filters were pretreated by passing about $50 \mathrm{~mL}$ of de-ionized water through the filter to minimize the risk of contamination from impurities in the commercial filter. The filters were air-dried prior to use. 
Density measurements for the as-received slurry and the supernatant phase were made with volumetric ware and a balance in the shielded cell. The density of the wet centrifuged solids was measured by reading the volume of solids in a graduated glass centrifuge tube after centrifugation and then weighing these solids.

Volume \% centrifuged liquid and volume \% centrifuged solids were made by reading the volume in the graduated centrifuge tube of each phase after centrifugation.

Weight $\%$ wet centrifuged solids was measured by weighing the as-received slurry in centrifuge tubes, centrifuging the tubes to effect separation, and weighing the wet solids left after the liquid fraction was decanted.

The total weight \% solids (both insoluble solids and soluble salts) were measured by heating sub-samples of the as-received slurry at $115 \pm 5^{\circ} \mathrm{C}$ until a constant dry weight was achieved. The samples were dried at $115^{\circ} \mathrm{C}$ rather than $105^{\circ} \mathrm{C}$ listed in the Test Specification because we have observed that this temperature is better for achieving a stable dry weight for samples with high dissolved salt content.

The weight $\%$ insoluble solids and weight $\%$ soluble solids were calculated after measuring the weight $\%$ total solids in the slurry and the weight $\%$ soluble solids in a filtered portion of the supernatant. This technique is used for determining the weight $\%$ insoluble solids rather than collecting and measuring the insoluble solids directly for two reasons: (1) it is less prone to experimental errors; and (2) it includes the water-soluble salts that would be dissolved during the water rinse of the solids to remove interstitial supernatant. The expression used for calculating the insoluble solids is:

$\mathrm{IS}=\mathrm{TS}-(100-\mathrm{TS}) \times(\mathrm{FS} / 100)$

$(1-\mathrm{FS} / 100)$

where:

IS $=$ weight $\%$ insoluble solids in the slurry

$\mathrm{TS}=$ weight $\%$ total solids in the slurry

$\mathrm{FS}=$ weight $\%$ soluble solids in the filtered supernatant

The weight \% soluble solids in the as-received slurry (SS) was then calculated from the difference in measured total weight \% solids in the slurry (TS) and the calculated weight \% insoluble solids (IS):

$\mathrm{SS}=\mathrm{TS}-\mathrm{IS}$

Note that we have distinguished between the weight \% soluble solids in the filtered supernatant (FS) and the weight \% soluble solids in the as-received slurry (SS). Since both of these values may be of process interest, they are both included in Table 5-1. 
The weight $\%$ solids in the solids fraction was measured by first centrifuging the as-received slurry and decanting the supernatant fraction. The wet solids that remained were weighed and dried to constant weight.

The weight $\%$ calcined solids in the supernatant fraction was measured by sequentially heating portions of the filtered supernatant to constant weight. The supernatant was first heated to simple dryness at $115^{\circ} \mathrm{C}$, and then heated to $1050^{\circ} \mathrm{C}$ to calcine these solids. The percent of calcined solids in the solids after simple drying is reported in Table 5-1.

The weight $\%$ calcined solids in the solid fraction was measured by sequentially heating portions of the unwashed wet solids to constant weight. The wet solids were first heated to simple dryness at $115^{\circ} \mathrm{C}$, and then heated to $1050{ }^{\circ} \mathrm{C}$ to calcine these solids. The percentage of calcined solids in the solids after simple drying is reported in Table 5-1.

Particle size measurements were made with a contained scanning electron microscope. The radioactivity of the solids was too high to permit removing enough of the solids (about $300 \mathrm{mg}$ ) to perform particle size analysis by laser scattering techniques. About $10 \mathrm{mg}$ of solids were removed from the cells and examined by scanning electron microscope. The dry solids contained a few large aggregates in range of 400-500 micrometers in diameter. However, these particles were clearly comprised of particles less than 10 micrometers. The average particle size in the entire sample was less than 10 micrometers. Pertinent micrographs from which the particle sizes were measured are shown in Appendix C.

Calorimetry measurements were measured on three sub-samples of the AY-102/C-106 sludge that had been dried to remove free water to measure the cal $/ \mathrm{g}{ }^{\circ} \mathrm{C}$ as a function of temperature. The conversion factor of $4.1876 \mathrm{~J} / \mathrm{cal}$ was used to express the calorimetry measurements in terms of $\mathrm{J} / \mathrm{g}{ }^{\circ} \mathrm{C}$. The average value of $2.87 \mathrm{~J} / \mathrm{g}{ }^{\circ} \mathrm{C}$ was obtained with excellent precision and is included in Table 5-1. Plots of heat capacity as a function of temperature for the AY-102/C106 sludge fraction are shown in Appendix D. 
Table 5-1. Physical Properties of AY-102/C-106

\begin{tabular}{|c|c|c|c|c|c|c|c|}
\hline Property & Unit & $\begin{array}{c}1^{\text {st }} \\
\text { Analysis }\end{array}$ & $\begin{array}{c}2^{\text {nd }} \\
\text { Analysis }\end{array}$ & $\begin{array}{c}3^{\text {rd }} \\
\text { Analysis }\end{array}$ & $\begin{array}{l}\text { Average } \\
\text { Analysis }\end{array}$ & $\begin{array}{l}\text { RSD } \\
\text { (\%) }\end{array}$ & $\begin{array}{l}\text { QC } \\
\text { Flag }\end{array}$ \\
\hline $\begin{array}{l}\text { Density of } \\
\text { As-Received Slurry }\end{array}$ & $\mathrm{g} / \mathrm{mL}$ & 1.20 & 1.19 & 1.20 & 1.20 & $1 \%$ & - \\
\hline $\begin{array}{l}\text { Density of Filtered } \\
\text { Supernatant }\end{array}$ & $\mathrm{g} / \mathrm{mL}$ & 1.15 & 1.14 & 1.16 & 1.15 & $1 \%$ & - \\
\hline $\begin{array}{l}\text { Density of Wet } \\
\text { Centrifuged Solids }\end{array}$ & $\mathrm{g} / \mathrm{mL}$ & 1.36 & 1.35 & 1.40 & 1.37 & $2 \%$ & - \\
\hline $\begin{array}{l}\text { Vol. \% Centrifuged } \\
\text { Solids }\end{array}$ & $\%$ & 18 & 18 & 18 & 18 & $0 \%$ & - \\
\hline $\begin{array}{l}\text { Vol. \% Centrifuged } \\
\text { Liquid }\end{array}$ & $\%$ & 82 & 82 & 82 & 82 & $0 \%$ & - \\
\hline $\begin{array}{l}\text { Wt. \% Wet } \\
\text { Centrifuged Solids } \\
\text { in the as-received } \\
\text { slurry }\end{array}$ & $\%$ & 20.1 & 20.3 & 20.8 & 20.4 & $2 \%$ & - \\
\hline $\begin{array}{l}\text { Wt. \% Total Dried } \\
\text { Solids (measured) }\end{array}$ & $\%$ & 21.3 & 21.2 & 21.1 & 21.2 & $2 \%$ & - \\
\hline $\begin{array}{l}\text { Wt. \% soluble } \\
\text { solids in the filtered } \\
\text { supernatant } \\
\text { (experimentally } \\
\text { measured) }\end{array}$ & $\%$ & 16.2 & 16.4 & 16.4 & 16.3 & $2 \%$ & - \\
\hline $\begin{array}{l}\text { QC Flags: - - meets all QC } \\
U_{B} \text { - blank exceeds } 5 \% \text { of } s \\
U_{O^{-}} \text {Outlier omitted in the }\end{array}$ & $\begin{array}{l}\text { nple cono } \\
\text { erage ana }\end{array}$ & & $\begin{array}{l}\text { - fails \% RS } \\
\text { - fails \% Rec } \\
\text { - not applic } \\
\end{array}$ & $\begin{array}{l}\text { criteria } \\
\text { ery of LCS }\end{array}$ & \multicolumn{3}{|c|}{$\begin{array}{l}\mathrm{U}_{\mathrm{M}} \text { - fails min. reportable quantity } \\
\mathrm{U}_{\mathrm{S}} \text { - fails \% Recovery of MS }\end{array}$} \\
\hline
\end{tabular}


Table 5-1. Physical Properties of AY-102/C-106 - page 2 of 2

\begin{tabular}{|c|c|c|c|c|c|c|c|}
\hline Property & Unit & $\begin{array}{c}1^{\text {st }} \\
\text { Analysis }\end{array}$ & $\begin{array}{c}2^{\text {nd }} \\
\text { Analysis }\end{array}$ & $\begin{array}{c}3^{\text {rd }} \\
\text { Analysis }\end{array}$ & $\begin{array}{l}\text { Average } \\
\text { Analysis }\end{array}$ & $\begin{array}{l}\text { RSD } \\
(\%)\end{array}$ & $\begin{array}{l}\text { QC } \\
\text { Flag }\end{array}$ \\
\hline $\begin{array}{l}\text { Wt \% soluble } \\
\text { solids in the } \\
\text { AY-102/C-106 } \\
\text { slurry (calculated } \\
\text { by difference in } \\
\text { total solids and } \\
\text { insoluble solids) }\end{array}$ & $\%$ & $\begin{array}{c}15.4 \\
\text { (average) }\end{array}$ & $\begin{array}{c}15.4 \\
\text { (average) }\end{array}$ & $\begin{array}{c}15.4 \\
\text { (average) }\end{array}$ & 15.4 & N/A & - \\
\hline $\begin{array}{l}\text { Wt. \% insoluble } \\
\text { solids } \\
\text { (calculated from } \\
\text { average total solids } \\
\text { \& dissolved solids) }\end{array}$ & $\%$ & $\begin{array}{c}5.85 \\
\text { (average) }\end{array}$ & $\begin{array}{c}5.85 \\
\text { (average) }\end{array}$ & $\begin{array}{c}5.85 \\
\text { (average) }\end{array}$ & 5.85 & N/A & - \\
\hline $\begin{array}{l}\text { Wt. \% total solids } \\
\text { in the centrifuged } \\
\text { solids fraction }\end{array}$ & $\%$ & 45.7 & 45.5 & 45.3 & 45.5 & $1 \%$ & - \\
\hline $\begin{array}{l}\text { Wt. \% calcined } \\
\text { solids in liquid } \\
\text { fraction } \\
\text { (g oxide/g dry } \\
\text { solids) }\end{array}$ & $\%$ & 93.1 & 91.4 & 90.7 & 91.7 & $1 \%$ & - \\
\hline $\begin{array}{l}\text { Wt. \% calcined } \\
\text { solids in dry solids } \\
\text { (g oxide/g dry } \\
\text { solids) }\end{array}$ & $\%$ & 73.7 & 75.5 & 76.2 & 75.1 & $2 \%$ & - \\
\hline \multirow{2}{*}{$\begin{array}{l}\text { Particle size by } \\
\text { SEM } \\
\text { (See Appendix C) }\end{array}$} & \multirow{2}{*}{$\begin{array}{l}\text { Micro } \\
\text { meters }\end{array}$} & $<10$ & $<10$ & $<10$ & $<10$ & \multirow[t]{2}{*}{ N/A } & \multirow[t]{2}{*}{ - } \\
\hline & & \multicolumn{4}{|c|}{$\begin{array}{l}\text { The dry solids contained a few large } \\
\text { aggregates in range of } 400-500 \text { micrometers } \\
\text { in diameter. However, these particles were } \\
\text { clearly comprised of particles less than } 10 \\
\text { micrometers. The average particle size in the } \\
\text { entire sample was less than } 10 \text { micrometers. }\end{array}$} & & \\
\hline $\begin{array}{l}\text { Calorimetry } \\
\text { (measured on dry } \\
\text { solids) } \\
\text { (See Appendix D) }\end{array}$ & $\mathrm{J} / \mathrm{g}{ }^{\circ} \mathrm{C}$ & 2.87 & 2.88 & 2.87 & 2.87 & $1 \%$ & - \\
\hline \multicolumn{3}{|c|}{$\begin{array}{l}\text { QC Flags: - - meets all QC } \\
\mathrm{U}_{\mathrm{B}} \text { - blank exceeds } 5 \% \text { of sample concentration } \\
\mathrm{U}_{\mathrm{O}^{-}} \text {Outlier omitted in the average analysis }\end{array}$} & $\begin{array}{l}I_{R}-\text { fails } \% \text { RSD } \\
L \text { - fails \% Reco } \\
\text { /A - not applica }\end{array}$ & $\begin{array}{l}\text { criteria } \\
\text { very of LCS } \\
\text { le }\end{array}$ & \multicolumn{3}{|c|}{$\begin{array}{l}U_{M} \text { - fails min. reportable quantity } \\
U_{S} \text { - fails \% Recovery of MS }\end{array}$} \\
\hline
\end{tabular}


WSRC-TR-2003-00205, REVISION 0 SRT-RPP-2003-00086, REVISION 0

This page intentionally left blank. 


\subsection{CHEMICAL AND RADIONUCLIDE ANALYSIS OF THE SUPERNATANT FRACTION FROM AY-102/C-106}

\subsection{SUPERNATANT PRETREATMENT PRIOR TO ANALYSES}

The supernatant fraction was separated from the solids by using a bench top centrifuge to spin the samples at approximately $8000 \mathrm{rpm}$ for one hour in $30-\mathrm{mL}$ Teflon centrifuge tubes. The supernatant fraction was decanted and passed through a 0.45 -micrometer porosity cellulose filter before analysis. The filters were pretreated (to minimize the risk of the filters contaminating the samples) by passing about $50 \mathrm{~mL}$ of de-ionized water through the filter, then air-dried before use. The wet solids fraction left in the centrifuge tube was used for chemical and radionuclide determinations discussed in Section 7.

Determinations of anions, inorganic carbon, total organic carbon, total alkalinity, free hydroxide, ${ }^{14} \mathrm{C}$, and ${ }^{79} \mathrm{Se}$ were made without any pretreatment other than dilution with deionized water. The activity of the as-received filtered supernatant fraction allowed approximately 4-5 $\mathrm{mL}$ of the undiluted supernatant to be brought from the cells for analysis in unshielded fume hoods and still be below SRTC exposure limits of $<10 \mathrm{mrem} / \mathrm{hr} @ 30 \mathrm{cms}$ and $<1000 \mathrm{mrem} / \mathrm{hr}$ extremity for samples to be placed in unshielded radiohoods.

All elemental and most radionuclide determinations of the supernatant fraction were performed after pretreatment with concentrated $\mathrm{HNO}_{3}$ and $30 \% \mathrm{H}_{2} \mathrm{O}_{2}$ at $115^{\circ} \mathrm{C}$ in a sealed, pressurized Teflon container.

The digestion procedure used was an adaptation of the Hanford Analytical Services procedure LA-505-112, "Acid Digest Preparation of Sediments, Sludges, and Solids in 11A Hot Cells for Metal Analysis by ICP-MS, ICP-AES, GFAA, FLAA," issued by R. Akita and R.W.

Schroeder, Rev-Mod B-0, released 02/05/2001.

Although there were no solids in the filtered supernatant, this pretreatment was indicated to help digest organic species in the waste that could affect subsequent analyses. Organic carbon content was not measured on the acid-treated supernatant fraction to test for completeness of digestion. However, chemical separation techniques and instrumental analyses were performed with no indication of interference from organics. The digestion procedure resulted in approximately $5 \mathrm{~mL}$ of the supernatant diluted to a final volume of $100 \mathrm{~mL}$ to produce an approximate 20 -fold dilution. The actual volumes used for the three digestions based on weighing the sample aliquots and using the density factor of $1.15 \mathrm{~g} / \mathrm{mL}$ to convert to volume were:
Trial $1=4.81 \mathrm{~mL}$
Trial $2=4.76 \mathrm{~mL}$
Trial $3=4.58 \mathrm{~mL}$ 


\subsection{CHEMICAL ANALYSES OF THE SUPERNATANT FRACTION FROM AY-102/C-106}

Analytical Development Section (ADS) general instrumental analysis methods were applied to the supernatant fraction from AY-102/C-106. In many cases, specific instructions for analyzing the supernatant samples were supplied by ADS chemists. Additional QA/QC used for these samples included the concurrent analyses of blanks, laboratory control standards, and matrix spikes stipulated in the Test Specification. Table 6-1 lists the instrumental methods including the ADS procedure reference, and the analytes measured with this method. Our abbreviation of the method is included in parentheses and this same abbreviation is used to identify the analytical method in the data tables. 
Table 6-1. Instrumental Analysis Methods Used For Analyzing AY-102/C-106 Supernatant Fraction

\begin{tabular}{|c|c|c|c|}
\hline Analytical Method & $\begin{array}{l}\text { ADS } \\
\text { Method } \\
\text { Number }\end{array}$ & $\begin{array}{l}\text { Issue or } \\
\text { Last Rev } \\
\text { Date }\end{array}$ & $\begin{array}{l}\text { Analytes } \\
\text { Measured With } \\
\text { This Method }\end{array}$ \\
\hline $\begin{array}{l}\text { Ion Chromatography (IC) } \\
\text { "Analysis of Solutions by Ion Chromatography" }\end{array}$ & 2306 & $1 / 30 / 98$ & $\begin{array}{l}\mathrm{NO}_{3}^{-}, \mathrm{NO}_{2}^{-}, \mathrm{PO}_{4}^{3-} \\
\mathrm{SO}_{4}^{2-}, \mathrm{C}_{2} \mathrm{O}_{4}{ }^{2-}, \mathrm{Cl}^{-} \\
\mathrm{Br}^{-}, \mathrm{F}^{-}, \mathrm{CHO}_{2}^{-}\end{array}$ \\
\hline $\begin{array}{l}\text { Ion Exclusion Chromatography (Ion Exclusion } \\
\text { Chro.) } \\
\text { "Determination of Low Molecular Weight } \\
\text { Organic Acids by Ion Exclusion } \\
\text { Chromatography" }\end{array}$ & 2459 & $10 / 14 / 99$ & $\begin{array}{l}\text { citrate, acetate, } \\
\text { glycolate }\end{array}$ \\
\hline $\begin{array}{l}\text { Potentiometric Titrations (T) } \\
\text { "Titrametric Analysis Using the TIM } 900 \\
\text { System." Free Hydroxide is determined from the } \\
\text { first inflection point of the titration. The molarity } \\
\text { of the free hydroxide is converted to } \mathrm{mg} / \mathrm{L} \mathrm{OH}^{-} \\
\text {for reporting in Table } 6-2 \text {. Total Alkalinity is } \\
\text { determined by titration to } \mathrm{pH} 7 \text {. Since multiple } \\
\text { bases may contribute to the total alkalinity, the } \\
\text { concentration is reported in Table } 6-2 \text { as molarity } \\
\text { instead of } \mathrm{mg} / \mathrm{L} \text {. }\end{array}$ & 1206 & $9 / 24 / 02$ & $\begin{array}{l}\text { free hydroxide, total } \\
\text { alkalinity }\end{array}$ \\
\hline $\begin{array}{l}\text { Carbon Analyzer by Furnace Oxidation (CA) } \\
\text { "DC-190 High Temperature TOC Analyzer with } \\
\text { Remote Sampling Bay" }\end{array}$ & 2255 & $1 / 31 / 99$ & $\begin{array}{l}\text { total inorganic } \\
\text { carbon, total } \\
\text { organic carbon }\end{array}$ \\
\hline $\begin{array}{l}\text { Inductively Coupled Plasma-Atomic Emission } \\
\text { Spectroscopy (ICP-AES) } \\
\text { "Contained Inductively Coupled Plasma Emission } \\
\text { Spectrometer" }\end{array}$ & 1564 & $9 / 27 / 01$ & $\begin{array}{l}\mathrm{Ag}, \mathrm{Al}, \mathrm{B}, \mathrm{Ba}, \mathrm{Ca} \\
\mathrm{Cd}, \mathrm{Ce}, \mathrm{Cr}, \mathrm{Fe}, \mathrm{La} \\
\mathrm{Li}, \mathrm{Mg}, \mathrm{Ni}, \mathrm{P}, \mathrm{Pb}, \mathrm{S} \\
\mathrm{Si}, \mathrm{V}, \mathrm{Zn}, \mathrm{Zr}\end{array}$ \\
\hline $\begin{array}{l}\text { Inductively Coupled Plasma-Mass } \\
\text { Spectrometry (ICP-MS) } \\
\text { "Inductively Coupled Plasma- Mass } \\
\text { Spectrometer" }\end{array}$ & 1543 & $9 / 15 / 02$ & $\begin{array}{l}{ }^{133,135} \mathrm{Cs} \text { (contributing } \\
\text { along with }{ }^{137} \mathrm{Cs} \text { from } \\
\text { counting to total } \mathrm{Cs} \text { ) } \\
\mathrm{Cu}, \mathrm{Rb}, \mathrm{Th}, \mathrm{U}, \mathrm{W}\end{array}$ \\
\hline $\begin{array}{l}\text { Atomic Absorption Spectrometry (AAS) } \\
\text { "Procedure for Vapor/Hydride Generation Atomic } \\
\text { Absorption" }\end{array}$ & 1557 & $12 / 15 / 02$ & $\mathrm{As}, \mathrm{Hg}, \mathrm{Se}$ \\
\hline $\begin{array}{l}\text { Atomic Absorption Spectrometry (AAS) } \\
\text { "Procedure for Operating the Varian Spectraa-880 } \\
\text { Atomic Absorption Spectrometer" }\end{array}$ & 1554 & $12 / 15 / 02$ & $\mathrm{~K}, \mathrm{Na}$ \\
\hline
\end{tabular}




\subsection{CHEMICAL COMPOSITION OF AS-RECEIVED AY-102/C-106 FILTERED SUPERNATANT}

Analysis of filtered supernatant was relatively straightforward. The precision of the determinations was generally better than $10 \%$ RSD and relatively few QC flags were required on the analyses. We were surprised at the large preponderance of nitrite over nitrate, but this was borne out by our personal inspections of the chromatograms that clearly showed the nitrite peak as much larger than the nitrate peak. Moreover, this nitrite/nitrate ratio was also approximately maintained in the analysis of the wet solid fraction after a warm water strike (Table 7.2). Since the composition of the wet solids is over $50 \%$ interstitial supernatant, this analysis serves as independent confirmation that the nitrite/nitrate ratio in the supernatant fraction is reasonable.

All measurements in Table 6-2 were performed by the Analytical Development Section of SRTC, except for $\mathrm{CN}^{-}$and $\mathrm{NH}_{3}$ that were measured at BWXT on samples of supernatant prepared in the SRTC Shielded Cells. SRTC either has no method for these analytes or problems were encountered in the analysis. Mercury was analyzed by both SRTC and BWXT, but neither laboratory detected mercury in the caustic supernatant fraction. SRTC also has no method to reliably measure stable iodine at the Minimum Reportable Quantity stipulated in the Test Specification. Background contamination of iodine that may be incurred in ICP-MS measurements makes iodine determinations suspect at this concentration. 
Table 6-2. Chemical Composition of the AY-102/C-106 Filtered Supernatant

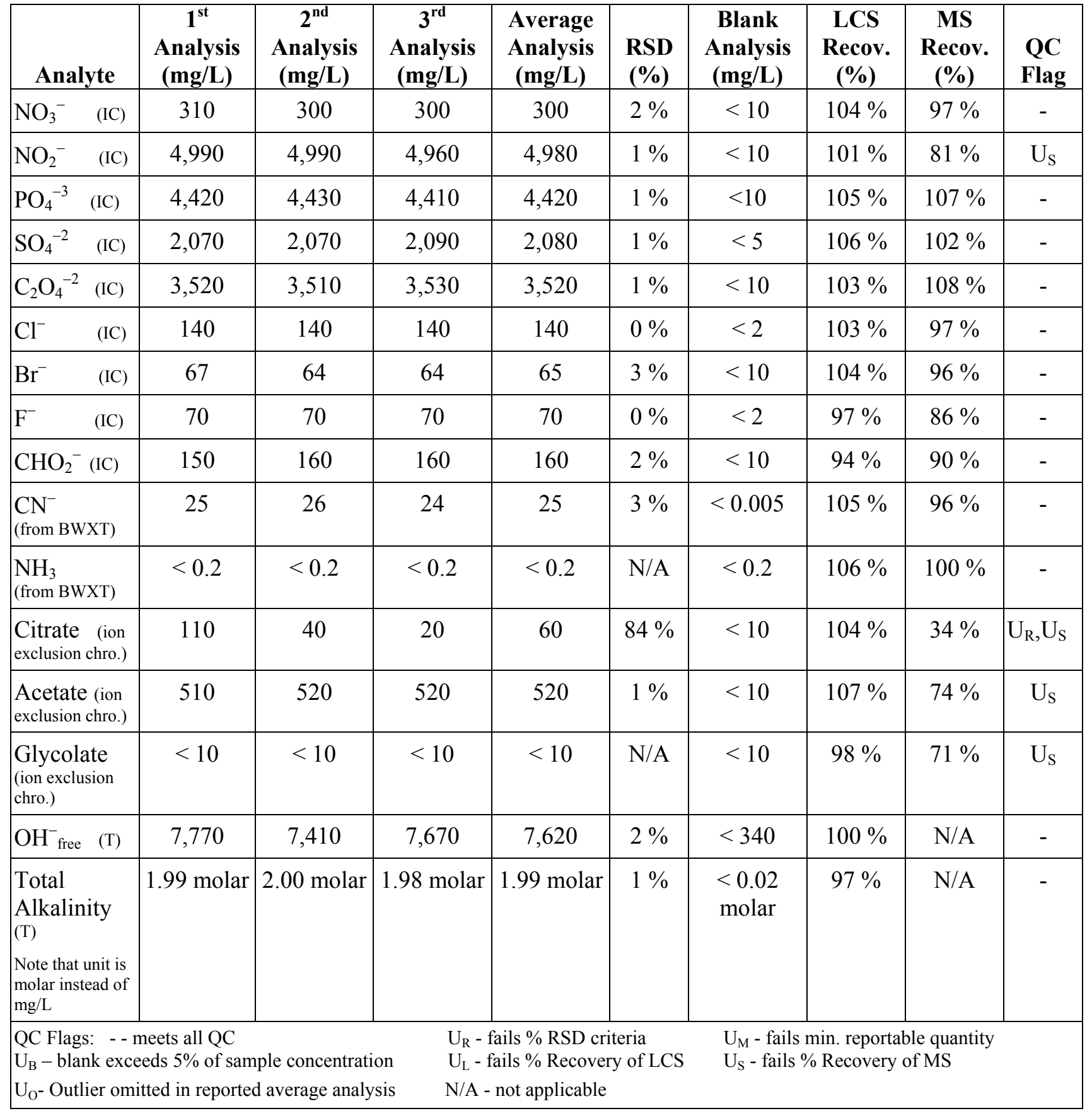


WSRC-TR-2003-00205, REVISION 0

SRT-RPP-2003-00086, REVISION 0

Table 6-2. Chemical Composition of the AY-102/C-106 Filtered Supernatant - page 2 of 3

\begin{tabular}{|c|c|c|c|c|c|c|c|c|c|}
\hline Analyte & $\begin{array}{c}1^{\text {st }} \\
\text { Analysis } \\
(\mathrm{mg} / \mathrm{L})\end{array}$ & $\begin{array}{c}2^{\text {nd }} \\
\text { Analysis } \\
(\mathrm{mg} / \mathrm{L})\end{array}$ & $\begin{array}{c}3^{\text {rd }} \\
\text { Analysis } \\
(\mathrm{mg} / \mathrm{L})\end{array}$ & $\begin{array}{c}\text { Average } \\
\text { Analysis } \\
(\mathrm{mg} / \mathrm{L})\end{array}$ & $\begin{array}{l}\text { RSD } \\
(\%)\end{array}$ & $\begin{array}{c}\text { Blank } \\
\text { Analysis } \\
(\mathrm{mg} / \mathrm{L})\end{array}$ & $\begin{array}{c}\text { LCS } \\
\text { Recov. } \\
(\%)\end{array}$ & $\begin{array}{c}\text { MS } \\
\text { Recov. } \\
(\%)\end{array}$ & $\begin{array}{l}\text { QC } \\
\text { Flag }\end{array}$ \\
\hline $\begin{array}{l}\text { Total } \\
\text { Inorganic } \\
\text { Carbon (CA) }\end{array}$ & 15,400 & 15,600 & 12,100 & 14,400 & $14 \%$ & 2 & $99 \%$ & $120 \%$ & $\mathrm{U}_{\mathrm{S}}$ \\
\hline $\begin{array}{l}\text { Total } \\
\text { Organic } \\
\text { Carbon (CA) }\end{array}$ & 6,510 & 5,740 & 6,680 & 6,310 & $8 \%$ & $<250$ & $97 \%$ & $81 \%$ & $\mathrm{U}_{\mathrm{S}}$ \\
\hline Ag (ICP-AES) & 4 & 5 & 4 & 4 & $11 \%$ & $<2$ & $101 \%$ & N/A & - \\
\hline As (AAS) & $<1$ & $<1$ & $<1$ & $<1$ & $\mathrm{~N} / \mathrm{A}$ & $<1$ & $99 \%$ & $138 \%$ & $\mathrm{U}_{\mathrm{S}}, \mathrm{U}_{\mathrm{M}}$ \\
\hline $\mathrm{Al}$ (ICP-AES) & 4,260 & 4,420 & 4,440 & 4,370 & $2 \%$ & $<13$ & $99 \%$ & $\mathrm{~N} / \mathrm{A}$ & - \\
\hline $\mathrm{B}$ (ICP-AES) & $<7$ & $<7$ & $<7$ & $<7$ & $\mathrm{~N} / \mathrm{A}$ & $<7$ & $99 \%$ & $\mathrm{~N} / \mathrm{A}$ & - \\
\hline $\mathrm{Ba}$ (ICP-AES) & $<2$ & $<2$ & $<2$ & $<2$ & $\mathrm{~N} / \mathrm{A}$ & $<2$ & $99 \%$ & $100 \%$ & - \\
\hline $\mathrm{Ca}$ (ICP-AES) & $<6$ & $<6$ & $<6$ & $<6$ & $\mathrm{~N} / \mathrm{A}$ & $<6$ & $101 \%$ & $94 \%$ & - \\
\hline $\mathrm{Cd}$ (ICP-AES) & $<1$ & $<1$ & $<1$ & $<1$ & $\mathrm{~N} / \mathrm{A}$ & $<1$ & $99 \%$ & $97 \%$ & - \\
\hline $\mathrm{Ce}$ (ICP-AES) & $<7$ & $<7$ & $<7$ & $<7$ & N/A & $<7$ & $99 \%$ & N/A & - \\
\hline $\mathrm{Cr}$ (ICP-AES) & 80 & 84 & 84 & 83 & $3 \%$ & $<2$ & $100 \%$ & $96 \%$ & - \\
\hline $\begin{array}{l}\text { Cs }-133 \\
\text { (stable Cs) } \\
\text { (ICP-MS) }\end{array}$ & 1.0 & 1.1 & 1.0 & 1.0 & $3 \%$ & $<0.06$ & N/A & N/A & - \\
\hline $\begin{array}{l}\text { Cs-135 } \\
\text { (ICP-MS) }\end{array}$ & 0.22 & 0.23 & 0.21 & 0.22 & $5 \%$ & $<0.06$ & N/A & N/A & - \\
\hline $\begin{array}{l}\text { Cs-137 } \\
\text { (counting) }\end{array}$ & 0.27 & 0.28 & 0.28 & 0.28 & 0.28 & $<9.4 \mathrm{E}-4$ & N/A & & \\
\hline \begin{tabular}{|l|} 
Cs (total) \\
Sum of Cs- \\
$133,135,137$ \\
\end{tabular} & 1.5 & 1.6 & 1.5 & 1.5 & $4 \%$ & $<0.12$ & $102 \%$ & $100 \%$ & - \\
\hline $\mathrm{Cu}$ (ICP-MS) & $<1.2$ & $<1.2$ & $<1.3$ & $<1.3$ & $\mathrm{~N} / \mathrm{A}$ & $<1.3$ & $99 \%$ & N/A & - \\
\hline $\mathrm{Fe}$ (ICP-AES) & $<22$ & $<22$ & $<22$ & $<21$ & N/A & $<22$ & $101 \%$ & $97 \%$ & - \\
\hline \multicolumn{6}{|c|}{$\begin{array}{l}\text { QC Flags: - - meets all QC } \\
\mathrm{U}_{\mathrm{B}} \text { - blank exceeds } 5 \% \text { of sample concentration }\end{array}$} & \multicolumn{4}{|c|}{$\begin{array}{l}U_{M} \text { - fails min. reportable quantity } \\
U_{S} \text { - fails \% Recovery of MS }\end{array}$} \\
\hline
\end{tabular}


Table 6-2. Chemical Composition of the AY-102/C-106 Filtered Supernatant - page 3 of 3

\begin{tabular}{|c|c|c|c|c|c|c|c|c|c|}
\hline Analyte & $\begin{array}{c}1^{\text {st }} \\
\text { Analysis } \\
(\mathrm{mg} / \mathrm{L})\end{array}$ & $\begin{array}{c}2^{\text {nd }} \\
\text { Analysis } \\
(\mathrm{mg} / \mathrm{L})\end{array}$ & $\begin{array}{c}3^{\text {rd }} \\
\text { Analysis } \\
(\mathrm{mg} / \mathrm{L})\end{array}$ & $\begin{array}{c}\text { Average } \\
\text { Analysis } \\
(\mathrm{mg} / \mathrm{L})\end{array}$ & $\begin{array}{l}\text { RSD } \\
(\%)\end{array}$ & $\begin{array}{c}\text { Blank } \\
\text { Analysis } \\
(\mathrm{mg} / \mathrm{L})\end{array}$ & $\begin{array}{c}\text { LCS } \\
\text { Recov. } \\
(\%)\end{array}$ & $\begin{array}{c}\text { MS } \\
\text { Recov. } \\
(\%) \\
\end{array}$ & $\begin{array}{c}\text { QC } \\
\text { Flag }\end{array}$ \\
\hline $\begin{array}{l}\mathrm{Hg} \text { (determined } \\
\text { by SRTC on acid } \\
\text { digested and } \\
\text { diluted sample } \\
\text { by AAS) }\end{array}$ & $<2.3$ & $<2.3$ & $<2.3$ & $<2.3$ & $\mathrm{~N} / \mathrm{A}$ & $<2.3$ & $92 \%$ & $84 \%$ & $\mathrm{U}_{\mathrm{M}}, \mathrm{U}_{\mathrm{S}}$ \\
\hline $\begin{array}{l}\mathrm{Hg} \text { (determined } \\
\text { by BWXT on } \\
\text { undigested, } \\
\text { undiluted sample } \\
\text { by AAS) }\end{array}$ & $<0.0002$ & $<0.0002$ & $<0.0002$ & $<0.0002$ & $\mathrm{~N} / \mathrm{A}$ & $<0.0002$ & $97 \%$ & $97 \%$ & - \\
\hline $\begin{array}{l}\text { I-127 } \\
\text { (stable I) }\end{array}$ & \multicolumn{9}{|c|}{ No SRTC method for stable Iodine at the Minimum Reportable Quantity level. } \\
\hline $\mathrm{K} \quad$ (AAS) & 400 & 410 & 410 & 410 & $2 \%$ & 0.06 & $102 \%$ & $97 \%$ & - \\
\hline La (ICP-AES) & $<2$ & $<2$ & $<2$ & $<2$ & N/A & $<2$ & $99 \%$ & N/A & - \\
\hline Li (ICP-AES) & $<14$ & $<14$ & $<14$ & $<14$ & N/A & $<14$ & $101 \%$ & N/A & $\mathrm{U}_{\mathrm{M}}$ \\
\hline $\mathrm{Mg}$ (ICP-AES) & $<1$ & $<1$ & $<1$ & $<1$ & N/A & $<1$ & $100 \%$ & N/A & - \\
\hline $\mathrm{Na} \quad$ (AAS) & 72,400 & 75,800 & 75,200 & 74,500 & $2 \%$ & $<5$ & $99 \%$ & $98 \%$ & - \\
\hline $\mathrm{Ni}$ (ICP-AES) & $<3$ & $<3$ & $<3$ & $<3$ & N/A & $<3$ & $100 \%$ & $92 \%$ & - \\
\hline $\mathrm{P} \quad$ (ICP-AES) & 1,570 & 1,650 & 1,660 & 1,630 & $3 \%$ & $<16$ & $99 \%$ & N/A & - \\
\hline $\mathrm{Pb}$ (ICP-AES) & $<8$ & $<8$ & $<8$ & $<8$ & N/A & $<8$ & $99 \%$ & N/A & - \\
\hline $\mathrm{Rb}$ (ICP-MS) & 1.4 & 1.5 & 1.4 & 1.4 & $4 \%$ & $<0.005$ & $102 \%$ & $102 \%$ & - \\
\hline $\mathrm{S}$ (ICP-AES) & 770 & 810 & 820 & 800 & $3 \%$ & $<6$ & $101 \%$ & N/A & - \\
\hline Si (ICP-AES) & 59 & 62 & 65 & 62 & $5 \%$ & $<4$ & $104 \%$ & N/A & - \\
\hline $\mathrm{Se} \quad$ (AAS) & $<1$ & $<1$ & $<1$ & $<1$ & N/A & $<1$ & $114 \%$ & $119 \%$ & $\mathrm{U}_{\mathrm{S}}, \mathrm{U}_{\mathrm{M}}$ \\
\hline Th (ICP-MS) & 0.1 & 0.1 & 0.1 & 0.1 & $17 \%$ & $<0.01$ & $105 \%$ & N/A & $\mathrm{U}_{\mathrm{R}}$ \\
\hline $\begin{array}{lr}\mathrm{U} & \text { (ICP-MS) } \\
\text { Sum } & \text { of Isotopes }\end{array}$ & 38 & 38 & 40 & 39 & $4 \%$ & 0.03 & $99 \%$ & $118 \%$ & $\mathrm{U}_{\mathrm{S}}$ \\
\hline V (ICP-AES) & $<2$ & $<2$ & $<2$ & $<2$ & N/A & $<2$ & $100 \%$ & N/A & - \\
\hline W (ICP-MS) & 97 & 100 & 107 & 101 & $5 \%$ & $<0.01$ & $111 \%$ & $161 \%$ & $\mathrm{U}_{\mathrm{S}}$ \\
\hline Zn (ICP-AES) & $<1$ & $<1$ & $<1$ & $<1$ & N/A & $<1$ & $97 \%$ & N/A & - \\
\hline $\mathrm{Zr}$ (ICP-AES) & $<6$ & $<6$ & $<6$ & $<6$ & N/A & $<6$ & $100 \%$ & N/A & - \\
\hline $\begin{array}{l}\text { QC Flags: - - n } \\
U_{\mathrm{B}}-\text { blank exce } \\
\mathrm{U}_{\mathrm{O}} \text { - Outlier omi }\end{array}$ & $\begin{array}{l}\text { eets all QC } \\
\text { eds 5\% of san } \\
\text { thed in reporte }\end{array}$ & $\begin{array}{l}\text { le concentrat } \\
\text { average anal }\end{array}$ & $\begin{array}{l}\mathrm{U}_{\mathrm{R}}-1 \\
\mathrm{U}_{\mathrm{L}}-1 \\
\mathrm{~N} / \mathrm{A}\end{array}$ & $\begin{array}{l}\text { ils \% RSD cr } \\
\text { ils \% Recove } \\
\text { tot applicable }\end{array}$ & $\begin{array}{l}\text { ria } \\
\text { of LCS }\end{array}$ & $\begin{array}{l}U_{M}-\text { fai } \\
U_{S}-\text { fail }\end{array}$ & $\begin{array}{l}\text { in. reporta } \\
\text { Recovery }\end{array}$ & $\begin{array}{l}\text { quantity } \\
\text { MS }\end{array}$ & \\
\hline
\end{tabular}




\subsection{DISCUSSION OF QC FLAGS FOR TABLE 6-1}

As shown in Table 6-2, 13 of the 51 analyses of chemical components were QC flagged for not meeting one or more of the data quality objectives. For each analyte with QC flags, we provide the following comments/explanations.

Table 6-3. QC Flags for Chemical Composition Measurements on the Filtered Supernatant Phase of AY-102/C-106

\begin{tabular}{|c|c|c|c|}
\hline \multicolumn{4}{|c|}{ QCO = Quality Control Objective } \\
\hline Analyte & QC Flag & \multicolumn{2}{|c|}{ Comments on QC Flag } \\
\hline $\mathrm{NO}_{2}^{-} \quad$ (IC) & $\mathrm{U}_{\mathrm{S}}$ & \multicolumn{2}{|c|}{ The matrix spike recovery was $81 \%$ versus the QCO of $85-115 \%$. } \\
\hline $\begin{array}{l}\text { Citrate } \\
\text { (ion exclusion } \\
\text { chro.) }\end{array}$ & $\mathrm{U}_{\mathrm{R}}, \mathrm{U}_{\mathrm{S}}$ & \multicolumn{2}{|c|}{$\begin{array}{l}\text { The precision and the matrix spike were both poor, a reflection of } \\
\text { the difficulties of getting clean separations and measurements of } \\
\text { organic acids in this matrix. However, the measured average value } \\
\text { was below the MRQ. The low concentration of analyte also affected } \\
\text { data quality. }\end{array}$} \\
\hline $\begin{array}{l}\text { Acetate (ion } \\
\text { exclusion chro.) }\end{array}$ & $\mathrm{U}_{\mathrm{S}}$ & \multicolumn{2}{|c|}{ The matrix spike recovery was $74 \%$ versus the QCAC of $85-115 \%$. } \\
\hline $\begin{array}{l}\text { Glycolate } \\
\text { (ion exclusion } \\
\text { chro.) }\end{array}$ & $\overline{U_{S}}$ & \multicolumn{2}{|c|}{$\begin{array}{l}\text { The matrix spike recovery was } 71 \% \text { versus the QCAC of } 85-115 \\
\% \text {. No glycolate was detected in the sample, and the detection limit } \\
\text { was } 10 \mathrm{mg} / \mathrm{L} \text { versus the MRQ of } 150 \mathrm{mg} / \mathrm{L} \text {. }\end{array}$} \\
\hline $\begin{array}{l}\text { Total } \\
\text { Inorganic } \\
\text { Carbon } \\
\text { (CA) }\end{array}$ & $\mathrm{U}_{\mathrm{S}}$ & \multicolumn{2}{|c|}{ The matrix spike recovery was $120 \%$ versus the QCO of $85-115 \%$. } \\
\hline $\begin{array}{l}\text { Total } \\
\text { Organic } \\
\text { Carbon } \\
\text { (CA) }\end{array}$ & $\mathrm{U}_{\mathrm{S}}$ & \multicolumn{2}{|c|}{ The matrix spike recovery was $81 \%$ versus the QCO of $85-115 \%$. } \\
\hline As (AAS) & $\mathrm{U}_{\mathrm{S}}, \mathrm{U}_{\mathrm{M}}$ & \multicolumn{2}{|c|}{$\begin{array}{l}\text { The matrix spike recovery was } 138 \% \text { versus the QCO of } 85-115 \% \text {. } \\
\text { Also, the measured detection limit of } 1 \mathrm{mg} / \mathrm{L} \text { was greater the MRQ } \\
\text { of } 0.015 \mathrm{mg} / \mathrm{L} \text {. The only possibility for improving the detection } \\
\text { limit significantly would be to analyze the as-received supernatant } \\
\text { with no sample preparation or dilution. }\end{array}$} \\
\hline $\begin{array}{l}\text { Flags: - - } \\
\text { - blank exce } \\
\text { Outlier om }\end{array}$ & & $\begin{array}{l}\mathrm{U}_{\mathrm{R}} \text { - fails \% RSD criteria } \\
\mathrm{U}_{\mathrm{L}} \text { - fails \% Recovery of LCS } \\
\text { N/A - not applicable }\end{array}$ & $\begin{array}{l}U_{M} \text { - fails minimum MRQ criteria } \\
U_{S} \text { - fails \% Recovery of MS }\end{array}$ \\
\hline
\end{tabular}


Table 6-3. QC Flags for Chemical Composition Measurements on the Filtered Supernatant Phase of AY-102/C-106- page 2 of 2

\begin{tabular}{|c|c|c|c|}
\hline \multicolumn{4}{|c|}{ QCO $=$ Quality Control Objective } \\
\hline Analyte & QC Flag & \multicolumn{2}{|c|}{ Comments on QC Flag } \\
\hline $\begin{array}{l}\mathrm{Hg} \\
\text { (determined by } \\
\text { SRTC on acid } \\
\text { digested and } \\
\text { diluted sample } \\
\text { by AAS) }\end{array}$ & $\mathrm{U}_{\mathrm{S}}, \mathrm{U}_{\mathrm{M}}$ & \multicolumn{2}{|c|}{$\begin{array}{l}\text { The matrix spike recovery was } 84 \% \text {, slightly lower than the QCO } \\
\text { of } 85-115 \% \text {. Also, the measured detection limit of } 2 \mathrm{mg} / \mathrm{L} \text { was } \\
\text { greater than the MRQ of } 1.5 \mathrm{mg} / \mathrm{L} \text {. The MRQ could be achieved by } \\
\text { using a smaller dilution in the digestion step. Since the BWXT lab } \\
\text { performed analyses on the undiluted supernatant, this lab easily met } \\
\text { the MRQ, obviating the need for SRTC to perform a separate } \\
\text { digestion. }\end{array}$} \\
\hline $\begin{array}{l}\mathrm{Li} \\
\text { (ICP-AES) }\end{array}$ & $\mathrm{U}_{\mathrm{M}}$ & \multicolumn{2}{|c|}{$\begin{array}{l}\text { The measured detection limit of } 14 \mathrm{mg} / \mathrm{L} \text { is greater than the TMRQ } \\
\text { of } 2.3 \mathrm{mg} / \mathrm{L} \text {. }\end{array}$} \\
\hline Se (AAS) & $\mathrm{U}_{\mathrm{S}}, \mathrm{U}_{\mathrm{M}}$ & \multicolumn{2}{|c|}{$\begin{array}{l}\text { The matrix spike recovery was } 119 \% \text {, higher than the QCO of } \\
85-115 \% \text {. Also, the measured detection limit of } 1 \mathrm{mg} / \mathrm{L} \text { was } \\
\text { greater the MRQ of } 0.015 \mathrm{mg} / \mathrm{L} \text {. The only possibility for improving } \\
\text { the detection limit significantly would be to analyze the as-received } \\
\text { supernatant with no sample preparation or dilution at all. }\end{array}$} \\
\hline Th(ICP-MS) & $\mathrm{U}_{\mathrm{R}}$ & \multicolumn{2}{|c|}{$\begin{array}{l}\text { The RSD of the } 3 \text { determinations was } 17 \% \text {, higher than the QCO } \\
\text { of } 15 \% \text {. }\end{array}$} \\
\hline U (ICP-MS) & $\mathrm{U}_{\mathrm{S}}$ & \multicolumn{2}{|c|}{$\begin{array}{l}\text { The matrix spike recovery was } 118 \% \text {, slightly higher than the } \\
\text { QCAC of } 85-115 \% \text {. }\end{array}$} \\
\hline W (ICP-MS) & $\mathrm{U}_{\mathrm{S}}$ & \multicolumn{2}{|c|}{ The matrix spike recovery was $161 \%$ versus the QCO of $85-115 \%$} \\
\hline \multicolumn{2}{|c|}{$\begin{array}{l}\text { QC Flags: - - meets all QC } \\
\mathrm{U}_{\mathrm{B}} \text { - blank exceeds } 5 \% \text { of sample concentration } \\
\mathrm{U}_{\mathrm{O}^{-}} \text {- Outlier omitted in reported average analysis }\end{array}$} & $\begin{array}{l}\mathrm{U}_{\mathrm{R}} \text { - fails \% RSD criteria } \\
\mathrm{U}_{\mathrm{L}} \text { - fails \% Recovery of LCS } \\
\mathrm{N} / \mathrm{A} \text { - not applicable }\end{array}$ & $\begin{array}{l}\mathrm{U}_{\mathrm{M}} \text { - fails minimum MRQ criteria } \\
\mathrm{U}_{\mathrm{S}} \text { - fails \% Recovery of MS }\end{array}$ \\
\hline
\end{tabular}




\subsection{RADIONUCLIDE ANALYSES OF THE AY-102/C-106 FILTERED SUPERNATANT}

Most of the required radionuclide measurements were performed on aliquots of the filtered supernatant that were digested with the Hanford $\mathrm{HNO}_{3}-\mathrm{H}_{2} \mathrm{O}_{2}$ method discussed previously in Section 6.1. The solutions from the digestions were then removed from the shielded cells and analyzed with radiochemical separation and counting techniques to determine these radionuclides: ${ }^{3} \mathrm{H},{ }^{60} \mathrm{Co},{ }^{90} \mathrm{Sr},{ }^{99} \mathrm{Tc}$ (total), ${ }^{125} \mathrm{Sb},{ }^{126} \mathrm{Sb}+{ }^{126} \mathrm{Sn},{ }^{137} \mathrm{Cs},{ }^{154} \mathrm{Eu},{ }^{155} \mathrm{Eu},{ }^{231} \mathrm{~Pa},{ }^{238} \mathrm{Pu}$, ${ }^{239 / 240} \mathrm{Pu},{ }^{241} \mathrm{Pu},{ }^{241} \mathrm{Am},{ }^{243} \mathrm{Am},{ }^{242} \mathrm{Cm},{ }^{243 / 244} \mathrm{Cm}$, and total alpha. The radionuclides measured by counting techniques, but measured directly on the supernatant fraction without being digested by the Hanford $\mathrm{HNO}_{3}-\mathrm{H}_{2} \mathrm{O}_{2}$ method were ${ }^{14} \mathrm{C}$, ${ }^{79} \mathrm{Se}$, the pertechnetate form of ${ }^{99} \mathrm{Tc}$, and ${ }^{129} \mathrm{I}$.

${ }^{59 / 63} \mathrm{Ni}$ was not measured in the supernatant fraction because elemental analysis by ICP-AES showed no detectable amount of total $\mathrm{Ni}$. Because the $\mathrm{Ni}$ (solid fraction concentration)/ $\mathrm{Ni}$ (supernatant fraction) ratio is at least 1000:1, and because the amount of radioactive $\mathrm{Ni}$ in the solid fraction taxed the sensitivity of the radiochemistry methods, we sought and received concurrence from WTP personnel to not pursue Ni radionuclide measurements on the AY-102/C-106 supernatant phase.

Inductively Coupled Plasma-Mass Spectroscopy (ICP-MS) was used to measure the following radionuclides with relatively long half-lives: ${ }^{135} \mathrm{Cs},{ }^{233} \mathrm{U},{ }^{234} \mathrm{U},{ }^{235} \mathrm{U},{ }^{236} \mathrm{U},{ }^{238} \mathrm{U},{ }^{237} \mathrm{~Np},{ }^{239} \mathrm{Pu}$, ${ }^{240} \mathrm{Pu}$. The following ICP-MS procedure was used in the measurements:

Reference: ADS Procedure 1543: "Inductively Coupled Plasma-Mass Spectrometer," Issue Date: 9/15/2002, Author: M.A. Malek.

ICP-MS determinations of radionuclides were reported in $\mu \mathrm{g} / \mathrm{g}$ of the supernatant. To convert these values to $\mathrm{mCi} / \mathrm{L}$ as required by the Test Specification, the density of the supernatant $(1.15 \mathrm{~g} / \mathrm{mL})$ and the specific activity of each radionuclide were used. Specific activities for pertinent radionuclides were obtained from "Integrated Data Base Report-1994: U.S. Spent Nuclear Fuel and Radioactive Waste Inventories, Projections, and Characteristics," Appendix B, pages 277 and 280, DOE/RW-0006, September, 1995, prepared by the Oak Ridge National Laboratory.

\begin{tabular}{|c|c|}
\hline Radionuclide Determined by ICP-MS & Specific Activty of Radionuclide (Ci/g) \\
\hline${ }^{135} \mathrm{Cs}$ & $1.15 \mathrm{E}-3$ \\
\hline${ }^{233} \mathrm{U}$ & $9.68 \mathrm{E}-3$ \\
\hline${ }^{234} \mathrm{U}$ & $6.25 \mathrm{E}-3$ \\
\hline${ }^{235} \mathrm{U}$ & $2.16 \mathrm{E}-6$ \\
\hline${ }^{236} \mathrm{U}$ & $6.47 \mathrm{E}-5$ \\
\hline${ }^{238} \mathrm{U}$ & $3.36 \mathrm{E}-7$ \\
\hline${ }^{237} \mathrm{~Np}$ & $7.05 \mathrm{E}-4$ \\
\hline${ }^{239} \mathrm{Pu}$ & $6.22 \mathrm{E}-2$ \\
\hline${ }^{240} \mathrm{Pu}$ & $2.28 \mathrm{E}-1$ \\
\hline
\end{tabular}




\section{Radiochemistry/Counting Method Narratives}

Because of the complexity of many of the methods used for radionuclide determinations of high-level waste, separate method description summaries and data reports were issued by the ADS radiochemistry laboratory for each measurement. The narratives (starting with Section 6.5.1) discuss the separation/counting methods used for measuring radionuclides in Table 6-4. These narratives are intended to convey the general flow of the method and do not include all the details of the method. The concentrations of radionuclides in the AY-102/C106 supernatant fraction measured by these techniques are reported as millicuries per liter $(\mathrm{mCi} / \mathrm{L})$ in Table 6-4.

\subsubsection{Determinations of ${ }^{3} \mathrm{H}$ in $\mathrm{AY}-102 / \mathrm{C}-106$ Filtered Supernatant}

Radiochemistry Reference: ADS Procedure 2444: "Tritium in Environmental Samples-A Distillation Procedure," Issue date: 4/1/1999, Author: R.A. Sigg.

\section{Radiochemistry Narrative:}

Document Number: SRT-ADS-2002-01341

Date of Issue: $\quad$ 7/21/2002

Authors: $\quad$ C.C. DiPrete and D.P. DiPrete

\section{Discussion:}

An aliquot of each sample was steam-distilled to separate the tritium fraction from the remainder of the sample. An aliquot of each distillate was added to liquid scintillation cocktail and analyzed for tritium. The samples were counted on a Packard Instruments liquid scintillation counter along with an instrument blank. The instrument blank was counted first and was used to establish an instrument background that was subtracted from the count results for the samples. 


\subsubsection{Determinations of ${ }^{14} \mathrm{C}$ in $\mathrm{AY}-102 / \mathrm{C}-106$ Filtered Supernatant}

Radiochemistry Reference: ADS Procedure 2424: "Gross Alpha/Beta Determination by Liquid Scintillation Counting," Issue date: 2/28/1999, Authors: J.D. Leyba and D.P. DiPrete.

\section{Radiochemistry Narrative:}

Document Number: SRT-ADS-2002-01540

Date of Issue: $\quad$ 11/15/2002

Authors: $\quad$ C.C. DiPrete and D.P. DiPrete

\section{Discussion:}

Aliquots of the as-received caustic sample were wet-ashed with a sodium persulfate/silver nitrate oxidation in conjunction with concentrated sulfuric acid. The carbon dioxide emitted was absorbed with Packard Instruments Carbosorb E. The Carbosorb E was then transferred to Ultima Gold $\mathrm{AB}$, and analyzed by liquid scintillation analysis for ${ }^{14} \mathrm{C}$. A laboratory control blank solution, spiked with a ${ }^{14} \mathrm{C}$ standard, was run in duplicate concurrently with the samples to determine ${ }^{14} \mathrm{C}$ recoveries. The average of the determinations was applied to the sample ${ }^{14} \mathrm{C}$ LSC results to quantify the ${ }^{14} \mathrm{C}$ concentrations in the samples. One sample was spiked with ${ }^{14} \mathrm{C}$ (again in duplicate) and run through the process to serve as the matrix spike. A second laboratory control blank solution, spiked with a ${ }^{14} \mathrm{C}$ standard, was run through the process to serve as the LCS sample. A 2-fold serial dilution of the sample was analyzed concurrently with the as-received samples. A blank solution was also run through the process to ensure no cross-contamination existed at the laboratory level. 


\subsubsection{Determinations of ${ }^{60} \mathrm{Co}$ in $\mathrm{AY}-102 / \mathrm{C}-106$ Filtered Supernatant}

Radiochemistry Reference: ADS Procedure 2420: "Gamma Sample Preparation and Analysis," Issue date: 3/31/2002, Author: C.C. DiPrete.

\section{Radiochemistry Narrative:}

Document Number: $\quad$ SRT-ADS-2002-01014

Date of Issue: $\quad 1 / 14 / 2003$

Authors: $\quad$ C.C. DiPrete and D.P. DiPrete

\section{Discussion:}

Analytical Development Section performed extended counting time gamma pulse height analyses on AY-102 supernatant fraction digested by acid. A sample aliquot was further acidified and ${ }^{137} \mathrm{Cs}$ levels were reduced by 2 addition/filtrations of Bio-Rad AMP-1 resin. The samples were then subsequently analyzed by gamma spectroscopy analysis using a high purity germanium detector for at least 8 hours. The gamma spectroscopy analysis uncertainties provided, which are based primarily on counting statistics, are 1 sigma. Results are background subtracted.

\subsubsection{Determinations of ${ }^{79} \mathrm{Se}$ in $\mathrm{AY}-102 / \mathrm{C}-106$ Filtered Supernatant}

Radiochemistry Reference: ADS Procedure 2424: “Gross Alpha/Beta Determination by Liquid Scintillation Counting," Issue date: 2/28/1999, Authors: J.D. Leyba and D.P. DiPrete.

\section{Radiochemistry Narrative:}

Document Number: SRT-ADS-2003-01578

Date of Issue: $\quad$ 9/28/2003

Authors: $\quad$ D.P. DiPrete

\section{Discussion:}

The Analytical Development Section performed analyses for ${ }^{79}$ Se on the AY-102 undiluted as-received supernatant fraction. Sample aliquots were spiked initially with stable Se which acted as both a chemical carrier and a Se yield tracer for the ${ }^{79} \mathrm{Se}$ measurements. The samples were then oxidized. Next the solutions were reduced to precipitate Se metal. The Se metal was washed repeatedly, re-dissolved, and the dissolution was then decontaminated with several types of analytical resins. The decontaminated solutions were then concentrated. Aliquots of the concentrate were analyzed by neutron activation analysis to determine Se carrier yields, and by liquid scintillation to measure ${ }^{79}$ Se activities. 


\subsubsection{Determinations of ${ }^{90} \mathrm{Sr}$ in $\mathrm{AY}-102 / \mathrm{C}-106$ Filtered Supernatant}

Radiochemistry Reference: ADS Procedure 2447: "Sr-90 in Environmental Samples," Issue date: 3/31/1998, Author: D.P. DiPrete.

\section{Radiochemistry Narrative:}

Document Number: SRT-ADS-2002-01358

Date of Issue: $\quad$ 7/31/2002

Authors: $\quad$ C.C. DiPrete and D.P. DiPrete

\section{Discussion:}

Analytical Development Section performed Sr separations and analyses on acid digested AY-102 supernatant. An aliquot of each sample was analyzed for ${ }^{90} \mathrm{Sr}$ using an Eichrom SrSpec based extraction procedure. A ${ }^{90} \mathrm{Sr}$-spiked blank and two ${ }^{90} \mathrm{Sr}$-spiked samples were analyzed with the sample batch to establish ${ }^{90} \mathrm{Sr} /{ }^{90} \mathrm{Y}$ counting efficiencies and Sr chemical recoveries. The blank and spikes were treated exactly like the samples. Once the extractions were complete, aliquots of the resultant ${ }^{90} \mathrm{Sr} /{ }^{90} \mathrm{Y}$-containing extracts mixed with liquid scintillation cocktail were counted in the ADS Radiochemistry Counting Facility. The samples were counted on a Packard Instruments liquid scintillation counter along with an instrument blank. The instrument blank was counted first and was used to establish an instrument background that was subtracted from the count results for the samples. Uncertainties provided, which are based primarily on counting statistics, are 1 sigma. Note: The rest of the narrative on the ${ }^{90} \mathrm{Sr}$ determinations of AY-102/C-106 supernatant was written by C.J. Coleman after a total of 3 sets of ${ }^{90} \mathrm{Sr}$ determinations were performed:

The initial set of ${ }^{90} \mathrm{Sr}$ data gave an average value of about $8.0 \mathrm{mCi} / \mathrm{L}$. This value exceeded the value of about $1.0 \mathrm{mCi} / \mathrm{L}$ obtained in the report "Filtration, Washing, and Leaching of a Hanford AY-102/C-106 Sample,” WSRC-TR-2003-00240, Rev.B; SRT-RPP-2003-00110, Rev. B; M.R. Poirier, P.R. Burket, J.L Siler, June 6, 2003, on the characterization of the filtrate from the Cells Unit Filter (CUF). Moreover, the measured ${ }^{90} \mathrm{Sr}$ concentration exceeded the maximum allowed concentration for Envelope A or Envelope B Hanford LowActivity Waste. To reconcile these discrepancies, the AY-102/C-106 supernatant was re-analyzed on two separate occasions. QC problems were observed in both sample sets, but measurements on the actual samples were comparable. The second set of analyses gave an average value of $1.75 \mathrm{mCi} / \mathrm{L}$, much more in line with the CUF data. However, this data set showed blank contamination. The third set of $90 \mathrm{Sr}$ determinations provided an average of $1.99 \mathrm{mCi} / \mathrm{L}$. This data set had an LCS recovery of $72 \%$, outside the control limit criteria of $85-115 \%$. Data from the three sets of analyses were reviewed with WTP staff and an agreement was reached for accepting $90 \mathrm{Sr}$ data from the second data set. This value of $1.75 \mathrm{mCi} / \mathrm{L}$ of ${ }^{90} \mathrm{Sr}$ is about $45 \%$ of the $3.9 \mathrm{mCi} / \mathrm{L}$ maximum allowed concentration of ${ }^{90} \mathrm{Sr}$ for the AY-102/C-106 supernatant to be below the maximum concentration for Envelope A or Envelope B Low-Activity Waste. 


\subsubsection{Determinations of ${ }^{99} \mathrm{Tc}$ (Total) in AY-102/C-106 Filtered Supernatant}

Radiochemistry Reference: ADS Procedure 2445: “999 Tc by Extraction Chromatography,” Issue date: 2/14/1999, Author: R.A. Sigg.

\section{Radiochemistry Narrative:}

Document Number: SRT-ADS-2002-01349

Date of Issue: $\quad$ 7/28/2002

Authors: $\quad$ C.C. DiPrete and D.P. DiPrete

\section{Discussion:}

Analytical Development Section measured ${ }^{99} \mathrm{Tc}$ on a set of acid digested AY-102 supernatant samples. The samples were digested/oxidized with a pressurized digestion method in the shielded cells prior to any radiochemistry being carried out on the samples.

${ }^{99 \mathrm{~m}} \mathrm{Tc}$ tracers were generated initially by neutron irradiation of natural molybdenum using SRTC's ${ }^{252} \mathrm{Cf}$ Neutron Activation Analysis facility. ${ }^{98} \mathrm{Mo}$ was activated to ${ }^{99}$ Mo that subsequently beta decayed to ${ }^{99 \mathrm{~m}} \mathrm{Tc}$. The ${ }^{99 \mathrm{~m}} \mathrm{Tc}$ was then extracted from the ${ }^{99} \mathrm{Mo}$, and oxidized to form a ${ }^{99 \mathrm{~m}} \mathrm{Tc}$ pertechnetate tracer.

Sample aliquots were spiked with a ${ }^{99 \mathrm{~m}} \mathrm{Tc}$ tracer, and the ${ }^{99} \mathrm{Tc}$ was subsequently extracted using an Aliquat 336 (in the form of Eichrom TEVA) based extraction. Aliquat 336 extracts ${ }^{99} \mathrm{Tc}$ in the pertechnetate form. As the samples were treated by a pressurized acid digestion and maintained under oxidizing conditions prior to receipt by radiochemistry, it was assumed all ${ }^{99} \mathrm{Tc}$ present had been oxidized to the pertechnetate form. The extractant was then analyzed first by gamma spectroscopy to determine ${ }^{99 \mathrm{~m}} \mathrm{Tc}$ tracer recoveries, and then analyzed by liquid scintillation analysis to determine ${ }^{99} \mathrm{Tc}$ activities. ${ }^{99 \mathrm{~m}} \mathrm{Tc}$ tracer recoveries were applied to the liquid scintillation results to quantify the ${ }^{99} \mathrm{Tc}$. A blank solution was also run through the extraction process to ensure no cross-contamination existed at the laboratory level. A blank spiked with ${ }^{99} \mathrm{Tc}$ was run through the process as well.

As required by the program, a serially diluted sample was run through the process as well. A $0.5 \mathrm{~mL}$ sample aliquot was run through the process. All other samples were run through the process using $1 \mathrm{~mL}$ aliquots. 


\subsubsection{Determinations of ${ }^{99} \mathrm{Tc}$ (as the Pertechnetate Ion) in AY-102/C-106 Filtered Supernatant}

Radiochemistry Reference: ADS Procedure 2445: “999 Tc by Extraction Chromatography," Issue date: 2/14/1999, Author: R.A. Sigg.

\section{Radiochemistry Narrative:}

Document Number: SRT-ADS-2003-01040

Date of Issue: $\quad$ 1/22/2003

Authors: $\quad$ C.C. DiPrete and D.P. DiPrete

\section{Discussion:}

${ }^{99} \mathrm{~m}$ Tc tracers were generated initially by neutron irradiation of natural molybdenum using SRTC's ${ }^{252}$ Cf Neutron Activation Analysis facility. ${ }^{98}$ Mo was activated to ${ }^{99}$ Mo that subsequently beta decayed to ${ }^{99 \mathrm{~m}} \mathrm{Tc}$. The ${ }^{99 \mathrm{~m}} \mathrm{Tc}$ is then extracted from the ${ }^{99} \mathrm{Mo}$, and oxidized to form a ${ }^{99 \mathrm{~m}} \mathrm{Tc}$ pertechnetate tracer. Aliquots of filtered supernatant (with no pretreatment with oxidizing acids) were spiked with ${ }^{99 \mathrm{~m}} \mathrm{Tc}$ tracer, and the ${ }^{99} \mathrm{Tc}$ was subsequently extracted using an Aliquat 336 (Eichrom TEVA) based extraction. Aliquat 336 extracts ${ }^{99 \mathrm{~m}} \mathrm{Tc}$ in the pertechnetate form. Aliquots of the extractants were analyzed by gamma spectroscopy to determine ${ }^{99 \mathrm{~m}} \mathrm{Tc}$ tracer recoveries. Aliquots were also analyzed by liquid scintillation analysis to determine ${ }^{99} \mathrm{Tc}$ activities. ${ }^{99 \mathrm{~m}} \mathrm{Tc}$ tracer recoveries were applied to the liquid scintillation results to quantify the ${ }^{99} \mathrm{Tc}$. A blank solution was also analyzed along with the sample batch to ensure no contamination was evident at the laboratory level. A blank spiked with ${ }^{99}$ Tc was also analyzed.

\subsubsection{Determinations of ${ }^{125} \mathrm{Sb}$ in AY-102/C-106 Filtered Supernatant}

Radiochemistry Reference: ADS Procedure 2420: "Gamma Sample Preparation and Analysis," Issue date: 3/31/2002, Author: C.C. DiPrete.

\section{Radiochemistry Narrative:}

The ${ }^{125} \mathrm{Sb}$ was obtained from the same gamma PHA measurements after ${ }^{137} \mathrm{Cs}$ removal as the other gamma emitters requiring this pretreatment step and then extended gamma-counting times. The ${ }^{125} \mathrm{Sb}$ was not reported in the same narrative as the other radionuclides, hence this narrative on the separation and counting technique used. 


\subsubsection{Determinations of ${ }^{126} \mathrm{Sb}+{ }^{126} \mathrm{Sn}$ in $\mathrm{AY}-102 / \mathrm{C}-106$ Filtered}

Radiochemistry Reference: ADS Procedure 2420: "Gamma Sample Preparation and Analysis," Issue date: 3/31/2002, Author: C.C. DiPrete.

\section{Radiochemistry Narrative:}

Document Number: SRT-ADS-2002-01014

Date of Issue: $\quad$ 1/14/2003 C.C. DiPrete and D.P. DiPrete

Authors:

\section{Discussion:}

The Analytical Development Section (ADS) performed extended counting time gamma pulse height analyses on AY-102 supernatant phase digested by acid. The ${ }^{137} \mathrm{Cs}$ was first stripped to permit gamma analysis of the low-level gamma emitters. A sample aliquot was treated with additional nitric acid and ${ }^{137} \mathrm{Cs}$ levels were reduced by two treatments with Bio-Rad AMP-1 resin. The samples were then subsequently analyzed by gamma spectroscopy analysis using a high purity germanium detector for at least 8 hours. The gamma spectroscopy analysis uncertainties provided, which are based primarily on counting statistics, are 1 sigma. Results are background subtracted. 


\subsubsection{Determinations of ${ }^{129} \mathrm{I}$ in $\mathrm{AY}-102 / \mathrm{C}-106$ Filtered Supernatant}

Radiochemistry Reference: ADS Procedure 2420: "Gamma Sample Preparation and Analysis," Issue date: 3/31/2002, Author: C.C. DiPrete.

\section{Radiochemistry Narrative:}

Document Number: SRT-ADS-2003-01010

Date of Issue: $\quad 1 / 13 / 2003$

Authors: $\quad$ C.C. DiPrete and D.P. DiPrete

\section{Discussion:}

The Analytical Development Section measured ${ }^{129}$ I determinations on AY-102 as-received caustic supernatant phase (with no acid digestion). A sample aliquot was spiked with stable iodide, stripped of ${ }^{137} \mathrm{Cs}$ using AMP-1 resin, then subjected to a silver iodide precipitation method to separate iodide in the matrix from other radionuclides. A de-ionized water blank was analyzed along with the batch. The precipitates were analyzed for ${ }^{129}$ I activity with a low-energy HPGE gamma spectroscopy detector. After the gamma analyses, the precipitates were analyzed by neutron activation analysis to determine the levels of stable iodide carrier in the precipitates. The recoveries of the iodide carrier were used to correct the gamma spectroscopy results for the ${ }^{129} \mathrm{I}$ recoveries. Results for the majority of samples are reported as upper limits, since we were not able to rule out a bias from the ${ }^{126} \mathrm{Sn}$ in the samples. The upper limits are still almost 4 orders of magnitude below the Minimum Reportable Quantity stipulated in the Test Specification. 


\subsubsection{Determinations of ${ }^{137} \mathrm{Cs}$ in AY-102/C-106 Filtered Supernatant}

Radiochemistry Reference: ADS Procedure 2420: "Gamma Sample Preparation and Analysis," Issue date: 3/31/2002, Author: C.C. DiPrete.

\section{Radiochemistry Narrative:}

Document Number: SRT-ADS-2002-01340

Date of Issue: $\quad$ 7/12/2002 C.C. DiPrete and D.P. DiPrete

Authors:

\section{Discussion:}

Analytical Development Section performed gamma pulse height analysis on acid digested AY-102/C-106 supernatant. An aliquot of each sample was analyzed by gamma spectroscopy analysis using a high purity germanium detector. Results are background subtracted.

\subsubsection{Determinations of ${ }^{154} \mathrm{Eu},{ }^{155} \mathrm{Eu},{ }^{231} \mathrm{~Pa}$ in AY-102/C-106 Filtered Supernatant}

Radiochemistry Reference: ADS Procedure 2420: "Gamma Sample Preparation and Analysis," Issue date: 3/31/2002, Author: C.C. DiPrete.

\section{Radiochemistry Narrative:}

Document Number: $\quad$ SRT-ADS-2002-01014

Date of Issue: $\quad$ 1/14/2003

Authors: $\quad$ C.C. DiPrete and D.P. DiPrete

\section{Discussion:}

The Analytical Development Section performed extended counting time gamma pulse height analyses on AY-102 supernatant phase digested by acid. The ${ }^{137} \mathrm{Cs}$ was first stripped to permit gamma analysis of the low-level gamma emitters. A sample aliquot was treated with additional nitric acid and ${ }^{137} \mathrm{Cs}$ levels were reduced by treatments with Bio-Rad AMP-1 resin. The samples were then subsequently analyzed by gamma spectroscopy analysis using a high purity germanium detector for at least 8 hours. The gamma spectroscopy analysis uncertainties provided, which are based primarily on counting statistics, are 1 sigma. Results are background subtracted. 


\subsubsection{Determinations of ${ }^{238} \mathrm{Pu},{ }^{239-240} \mathrm{Pu},{ }^{241} \mathrm{Pu}$ in $\mathrm{AY}-102 / \mathrm{C}-106$ Filtered Supernatant}

Radiochemistry Reference: ADS Procedure 2453: "Plutonium TTA Extraction and Alpha Analysis," Issue date: 9/28/1998, Author: D.P. DiPrete.

\section{Radiochemistry Narrative:}

Document Number: SRT-ADS-2002-01382

Date of Issue: $\quad$ 8/16/2002

Authors: $\quad$ C.C. DiPrete and D.P. DiPrete

\section{Discussion:}

Thenoyltrifluoroacetone (TTA) was used to separate $\mathrm{Pu}$ from other radionuclides in the AY-102 supernatant fraction. An aliquot of the sample dissolution was initially spiked with a Pu-238 tracer. A second aliquot of straight sample dissolution was analyzed along with the spiked sample. In addition, a third aliquot was used for determining the ${ }^{241} \mathrm{Pu}$ concentration. All the plutonium in the samples was reduced once using hydroxylamine. An anion complexant (aluminum nitrate) was then added, and the solutions were oxidized with 4M sodium nitrite. The plutonium was then extracted from the matrix using a TTA solution. The TTA layer was mounted on a counting dish, the mount was then analyzed by alpha spectroscopy. A blank sample was run with the sample set. Possible interference from ${ }^{241} \mathrm{Am}$ on the ${ }^{238} \mathrm{Pu}$ spike recovery was ruled out by review of the alpha spectrum that showed no aqueous phase (that would contain the ${ }^{241} \mathrm{Am}$ ) contamination had been incorporated into the alpha plate.

The ${ }^{239 / 240} \mathrm{Pu}$ alpha peaks were yielded using the recoveries from the ${ }^{238} \mathrm{Pu}$ traced sample separation. The ratio of the ${ }^{239 / 240} \mathrm{Pu} /{ }^{238} \mathrm{Pu}$ in the sample was obtained from the alpha spectroscopy analysis of the non-spiked sample. That ratio was applied to the determined ${ }^{239 / 240} \mathrm{Pu}$ value to determine the ${ }^{238} \mathrm{Pu}$ activity in the sample.

The sample aliquot dedicated to the ${ }^{241} \mathrm{Pu}$ analysis was added to liquid scintillation cocktail following the separation and analyzed for both ${ }^{241} \mathrm{Pu}$ and gross $\mathrm{Pu}-\mathrm{alph}$ constituents. The ratio of ${ }^{241} \mathrm{Pu}$ to total $\mathrm{Pu}$ alpha was determined and applied to the results from the plates in order to determine a ${ }^{241} \mathrm{Pu}$ concentration. 


\subsubsection{Determinations of ${ }^{241} \mathrm{Am},{ }^{243} \mathrm{Am},{ }^{242} \mathrm{Cm},{ }^{243 / 244} \mathrm{Cm}$ in $\mathrm{AY}-102 / \mathrm{C}-106$ Filtered Supernatant}

Radiochemistry Reference: ADS Procedure 2453: "Actinides in Environmental Samples," Issue date: 9/28/1998, Author: D.P. DiPrete.

\section{Radiochemistry Narrative:}

Document Number: $\quad$ SRT-ADS-2003-01070

Date of Issue: $\quad$ 1/31/2003

Authors: $\quad$ C.C. DiPrete and D.P. DiPrete

\section{Discussion:}

Aliquots of acid-digested AY-102 supernatant fraction were run through an $\mathrm{Am} / \mathrm{Cm}$ separation procedure to separate the trivalent $\mathrm{Am} / \mathrm{Cm}$ isotopes from the higher valence state actinides following a sample oxidation step. Samples were analyzed in duplicate, one sample spiked with ${ }^{243} \mathrm{Am}$ for yielding purposes, one sample with no spike to correct for any ${ }^{243} \mathrm{Am}$ that might be present in the samples. The Am/Cm sample mount was analyzed by alpha for ${ }^{244} \mathrm{Cm}$ and ${ }^{242} \mathrm{Cm}$ and by low energy gamma spectrometry for ${ }^{241} \mathrm{Am}$. The gamma results were yielded by using the ${ }^{243} \mathrm{Am}$ tracer gamma result to quantify the ${ }^{241} \mathrm{Am}$ activity in the samples. The ${ }^{241} \mathrm{Am}$ activity in the samples was high enough to swamp out the alpha spectrum peak for the ${ }^{243} \mathrm{Am}$ spike. As a result, the alpha results of ${ }^{242} \mathrm{Cm}$ and ${ }^{244} \mathrm{Cm}$ were quantified by taking the ratio of their alpha peaks to that of the ${ }^{241} \mathrm{Am}$ previously quantified in the gamma measurement. ${ }^{243} \mathrm{Am}$ values were quantified off a low energy gamma analysis of the mount containing no ${ }^{243} \mathrm{Am}$ spike, and were quantified using the ${ }^{243} \mathrm{Am} /{ }^{241} \mathrm{Am}$ ratio applied to the quantified ${ }^{241}$ Am activity.

A laboratory blank was analyzed concurrently with the samples. The blank digestion generated in the cells showed significant ${ }^{244} \mathrm{Cm}$ contamination, indicating that the ${ }^{244} \mathrm{Cm}$ results for the samples are likely biased high from cell cross-contamination. A potential positive bias for the ${ }^{242} \mathrm{Cm}$ may exist if any ${ }^{252} \mathrm{Cf}$ is present in the samples. However, all ${ }^{242} \mathrm{Cm}$ results are lower than the Minimum Reportable Quantity listed in the Test Specification. 


\subsubsection{Total Alpha Determinations of the AY-102/C-106 Filtered Supernatant}

Radiochemistry Reference: ADS Procedure 2402: “Alpha Pulse Height Analysis," Issue date: 12/31/2000, Author: J.D. Leyba

\section{Radiochemistry Narrative:}

Document Number: SRT-ADS-2003-01099

Date of Issue: $\quad$ 2/12/2003

Authors: $\quad$ C.C. DiPrete and D.P. DiPrete

\section{Discussion:}

Prior to the analyses, ${ }^{137} \mathrm{Cs}$ separations were performed to reduce bias caused by large beta/alpha ratios. This was accomplished using Bio-Rad AMP1 resin. Following the Cs removal process, aliquots of the Cs-stripped samples were mounted on stainless steel counting planchets and analyzed for alpha activity using a gas-flow proportional counter. Results are background subtracted.

The analysis was carried out four times to illustrate the consistency within our measurement for each given sample. Average results are provided. The \% RSD was 21.5. This is outside the requested range, but the $\%$ RSD values for the 4 laboratory replicates of each of the individual samples were $8.8 \%$ or below. Both the lab control spike and matrix spike recoveries were good.

Since most of the alpha counts should come from the transuranic (TRU) radionuclides, the total alpha and sum of TRU determinations should agree to within reasonable experimental uncertainties. The sum of TRU measurements are about $50 \%$ lower than total alpha because of imperfect separation of ${ }^{90} \mathrm{Sr}$ from the alpha emitters prior to total alpha counting, resulting in a high bias in the total alpha determinations.

\subsubsection{Sum of Transuranic Isotopic Measurements in AY-102/C-106 Filtered Supernatant}

The alpha-emitting transuranic (TRU) isotopes were summed from the individual measurements of ${ }^{238} \mathrm{Pu},{ }^{239} \mathrm{Pu},{ }^{237} \mathrm{~Np},{ }^{240-241} \mathrm{Pu},{ }^{241} \mathrm{Am},{ }^{243} \mathrm{Am},{ }^{242} \mathrm{Cm}$, and ${ }^{243 / 244} \mathrm{Cm}$. The sum of the individual TRU isotope measurements was about $50 \%$ lower than the total alpha measurements ( $4.3 \mathrm{E}-2 \mathrm{mCi} / \mathrm{L}$ sum of TRU isotopes vs. $6.3 \mathrm{E}-2 \mathrm{mCi} / \mathrm{L}$ total alpha). The discrepancy is caused by a high bias in the total alpha analysis from imperfect separation of the high levels of ${ }^{90} \mathrm{Sr}$ in the supernatant fraction prior to alpha counting.

The contribution of ${ }^{243 / 244} \mathrm{Cm}$ to the sum of TRU is particularly suspect because the ${ }^{244} \mathrm{Cm}$ level in the blank analysis was about $5 \%$ of the total TRU. Therefore, the TRU values are probably biased about $5 \%$ high from the ${ }^{244} \mathrm{Cm}$ contribution due to cross-contamination introduced in the shielded cell sample preparation steps. 
WSRC-TR-2003-00205, REVISION 0

SRT-RPP-2003-00086, REVISION 0

Table 6-4. Radionuclide Composition of AY-102/C-106 Filtered Supernatant

\begin{tabular}{|c|c|c|c|c|c|c|c|c|c|}
\hline Analyte & $\begin{array}{c}1^{\text {st }} \\
\text { Analysis } \\
(\mathrm{mCi} / \mathrm{L}) \\
\end{array}$ & $\begin{array}{c}2^{\text {nd }} \\
\text { Analysis } \\
(\mathrm{mCi} / \mathbf{L}) \\
\end{array}$ & $\begin{array}{c}3^{\text {rd }} \\
\text { Analysis } \\
(\mathrm{mCi} / \mathrm{L})\end{array}$ & $\begin{array}{l}\text { Average } \\
\text { Analysis } \\
(\mathrm{mCi} / \mathbf{L}) \\
\end{array}$ & $\begin{array}{l}\text { RSD } \\
(\%)\end{array}$ & $\begin{array}{c}\text { Blank } \\
\text { Analysis } \\
(\mathrm{mCi} / \mathrm{L})\end{array}$ & $\begin{array}{c}\text { LCS } \\
\text { Recov. } \\
(\%) \\
\end{array}$ & $\begin{array}{c}\text { MS } \\
\text { Recov. } \\
(\%) \\
\end{array}$ & $\begin{array}{c}\text { QC } \\
\text { Flag }\end{array}$ \\
\hline $\begin{array}{l}{ }^{3} \mathrm{H} \\
\text { (by counting) }\end{array}$ & $<5.5 \mathrm{E}-3$ & $<5.5 \mathrm{E}-3$ & $8.2 \mathrm{E}-3$ & $<8.2 \mathrm{E}-3$ & $>15 \%$ & $<5.5 \mathrm{E}-3$ & $96 \%$ & $94 \%$ & $\mathrm{U}_{\mathrm{R}}$ \\
\hline $\begin{array}{l}{ }^{14} \mathrm{C} \\
\text { (by counting) }\end{array}$ & $7.0 \mathrm{E}-4$ & $8.9 \mathrm{E}-4$ & $8.4 \mathrm{E}-4$ & $8.1 E-4$ & $12 \%$ & $<3.5 \mathrm{E}-5$ & $103 \%$ & $114 \%$ & - \\
\hline $\begin{array}{l}{ }^{59} \mathrm{Ni} \\
\mathrm{N} / \mathrm{A}\end{array}$ & \multicolumn{9}{|c|}{ Not measured (See Text In Section 6.5) } \\
\hline $\begin{array}{l}{ }^{63} \mathrm{Ni} \\
\mathrm{N} / \mathrm{A}\end{array}$ & \multicolumn{9}{|c|}{ Not measured (See Text In Section 6.5) } \\
\hline $\begin{array}{l}{ }^{60} \mathrm{Co} \\
\text { (by counting) }\end{array}$ & $1.5 E-3$ & $1.5 \mathrm{E}-3$ & $1.7 E-3$ & $1.6 E-3$ & $7 \%$ & $<1.5 \mathrm{E}-5$ & $\mathrm{~N} / \mathrm{A}$ & $\mathrm{N} / \mathrm{A}$ & - \\
\hline $\begin{array}{l}{ }^{79} \mathrm{Se} \\
\text { (by counting) }\end{array}$ & $2.1 \mathrm{E}-4$ & $1.4 \mathrm{E}-4$ & $1.0 \mathrm{E}-4$ & $1.5 \mathrm{E}-4$ & $37 \%$ & $<4.5 \mathrm{E}-5$ & $\begin{array}{l}\text { N/A (stable } \\
\text { Se spike } \\
\text { used to yield } \\
\text { recovery) }\end{array}$ & $\begin{array}{c}\text { N/A (stable } \\
\text { Se spike } \\
\text { used to yield } \\
\text { recovery) }\end{array}$ & $\mathrm{U}_{\mathrm{R}}$ \\
\hline $\begin{array}{l}{ }^{90} \mathrm{Sr} \\
\text { (by counting) }\end{array}$ & $1.75 \mathrm{E} 0$ & $1.67 \mathrm{E} 0$ & 1.83 E 0 & $1.75 \mathrm{E} 0$ & $5 \%$ & $2.59 \mathrm{E}-4$ & $88 \%$ & $103 \%$ & - \\
\hline $\begin{array}{l}{ }^{99} \mathrm{Tc} \text { (total) } \\
\text { (by counting) }\end{array}$ & $1.0 \mathrm{E}-2$ & $1.3 E-2$ & $1.2 \mathrm{E}-2$ & $1.2 \mathrm{E}-2$ & $11 \%$ & $<1.2 \mathrm{E}-4$ & $\begin{array}{c}\mathrm{N} / \mathrm{A}\left({ }^{99 \mathrm{~m}} \mathrm{Tc}\right. \\
\text { tracer used } \\
\text { to yield } \\
\text { recovery) }\end{array}$ & $\begin{array}{c}\mathrm{N} / \mathrm{A}\left({ }^{99 \mathrm{~m}} \mathrm{Tc}\right. \\
\text { tracer used } \\
\text { to yield } \\
\text { recovery) }\end{array}$ & - \\
\hline $\begin{array}{l}{ }^{99} \mathrm{Tc} \\
\left(\mathrm{TcO}_{4}^{-}\right) \\
\text {(by counting) }\end{array}$ & $1.2 \mathrm{E}-2$ & $1.2 \mathrm{E}-2$ & $1.1 \mathrm{E}-2$ & $1.2 \mathrm{E}-2$ & $2 \%$ & $<3.4 \mathrm{E}-5$ & $\begin{array}{c}\mathrm{N} / \mathrm{A}\left({ }^{99 \mathrm{~m}} \mathrm{Tc}\right. \\
\text { tracer used } \\
\text { to yield } \\
\text { recovery) }\end{array}$ & $\begin{array}{c}\mathrm{N} / \mathrm{A}\left({ }^{99 \mathrm{~m}} \mathrm{Tc}\right. \\
\text { tracer used } \\
\text { to yield } \\
\text { recovery) }\end{array}$ & - \\
\hline $\begin{array}{l}{ }^{125} \mathrm{Sb} \\
\text { (by counting) }\end{array}$ & $<9.4 \mathrm{E}-5$ & $<9.4 \mathrm{E}-5$ & $<7.8 \mathrm{E}-5$ & $<9.4 \mathrm{E}-5$ & $\mathrm{~N} / \mathrm{A}$ & $<3.9 \mathrm{E}-5$ & $\mathrm{~N} / \mathrm{A}$ & $\mathrm{N} / \mathrm{A}$ & - \\
\hline $\begin{array}{l}{ }^{126} \mathrm{Sb}+ \\
{ }^{126} \mathrm{Sn} \\
\text { (by counting) }\end{array}$ & $5.3 \mathrm{E}-4$ & $5.3 \mathrm{E}-4$ & $5.8 \mathrm{E}-4$ & $5.5 \mathrm{E}-4$ & $5 \%$ & $<1.3 \mathrm{E}-5$ & $\mathrm{~N} / \mathrm{A}$ & $\mathrm{N} / \mathrm{A}$ & - \\
\hline $\begin{array}{l}{ }^{129} \mathrm{I} \\
\text { (by counting) }\end{array}$ & $\begin{array}{l}<2.2 \\
E-5\end{array}$ & $\begin{array}{l}<1.8 \\
E-5\end{array}$ & $\begin{array}{l}<9.9 \\
E-6\end{array}$ & $\begin{array}{l}<2.2 \\
E-5\end{array}$ & N/A & $\begin{array}{l}<2.8 \\
E-5\end{array}$ & $\begin{array}{c}\text { N/A-I } \\
\text { traced by } \\
\text { NAA }\end{array}$ & $\begin{array}{c}\mathrm{N} / \mathrm{A}-\mathrm{I} \\
\text { traced by } \\
\mathrm{NAA}\end{array}$ & - \\
\hline $\begin{array}{l}{ }^{135} \mathrm{Cs} \\
\text { (by ICP-MS) }\end{array}$ & $2.5 \mathrm{E}-4$ & $2.6 E-4$ & $2.4 \mathrm{E}-4$ & $2.5 \mathrm{E}-4$ & $5 \%$ & $<6.6 \mathrm{E}-5$ & N/A & N/A & - \\
\hline $\begin{array}{l}\text { QC Flags: non } \\
U_{B}-\text { blank exc } \\
U_{O^{-}} \text {Outlier om }\end{array}$ & $\begin{array}{l}\text { eeds } 5 \% \text { of sa } \\
\text { eetted in report } \\
\text { itto }\end{array}$ & $\begin{array}{l}\text { le concentra } \\
\text { average ana }\end{array}$ & $\begin{array}{l}U_{R}-1 \\
U_{L}-1 \\
N / A-\end{array}$ & $\begin{array}{l}\text { fails \% RSD cri } \\
\text { fails \% Recover } \\
\text { - not applicable }\end{array}$ & $\begin{array}{l}\text { ria } \\
\text { of LCS }\end{array}$ & $\begin{array}{l}U_{M} \text { - fails } r \\
U_{S} \text { - fails } \%\end{array}$ & n. reportal & $\begin{array}{l}\text { equantity } \\
\text { MS }\end{array}$ & \\
\hline
\end{tabular}


WSRC-TR-2003-00205, REVISION 0

SRT-RPP-2003-00086, REVISION 0

Table 6-4. Radionuclide Composition of AY-102/C-106 Filtered Supernatant - page 2 of 3

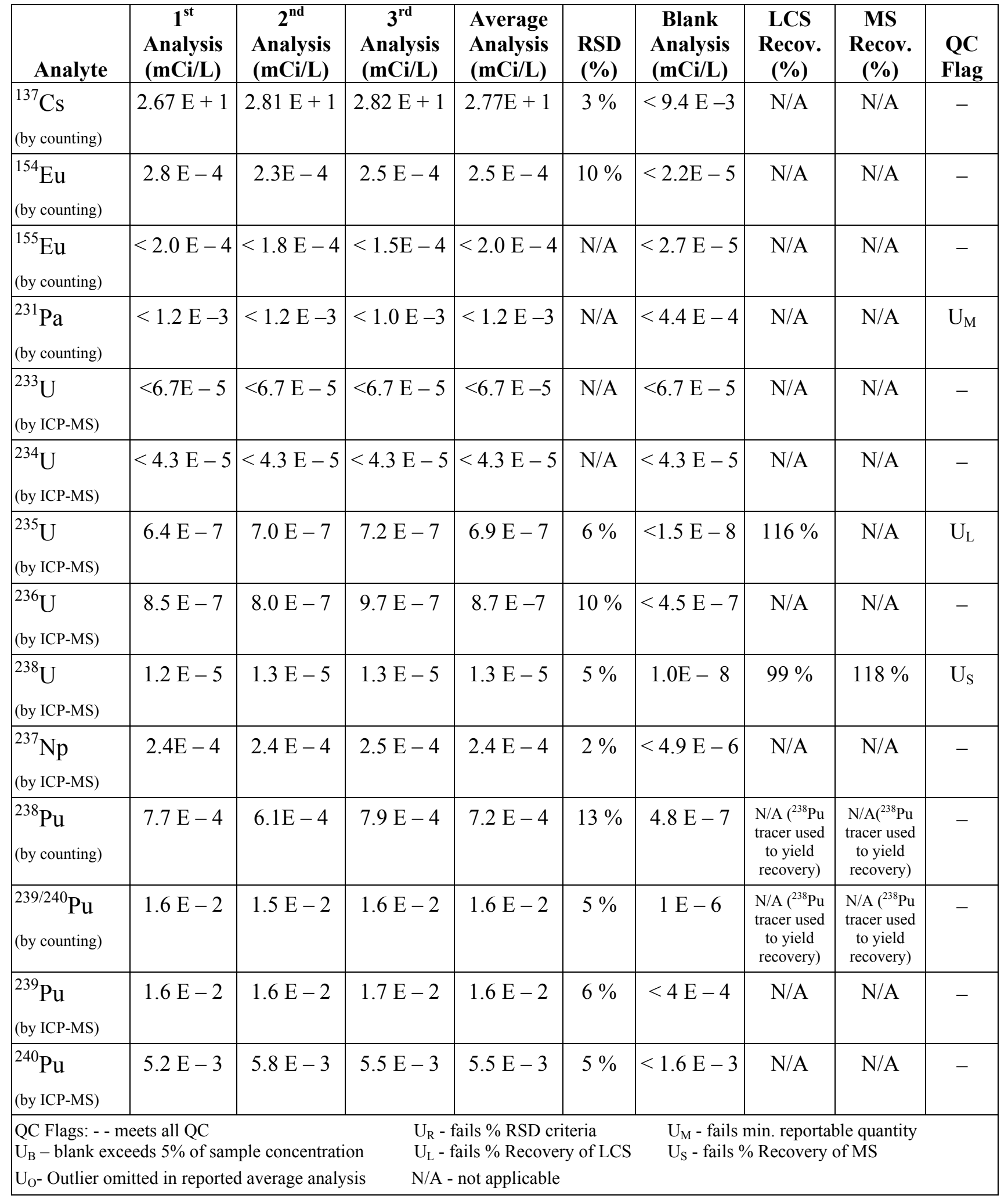


WSRC-TR-2003-00205, REVISION 0

SRT-RPP-2003-00086, REVISION 0

Table 6-4. Radionuclide Composition of AY-102/C-106 Filtered Supernatant - page 3 of 3

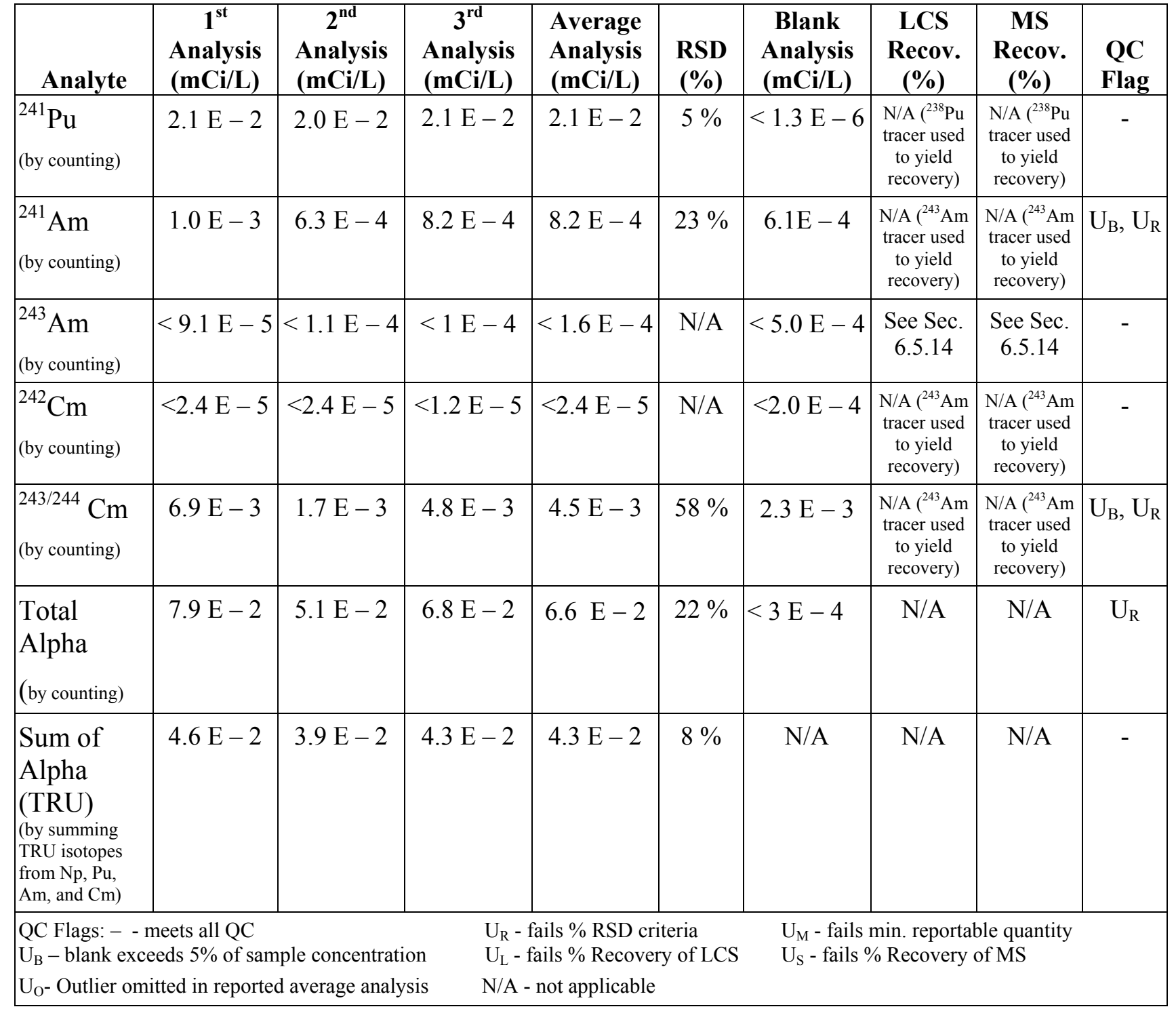

\subsection{DISCUSSION OF THE QC FLAGS FOR TABLE 6-4}

As shown in Table 6-4, 8 of the 31 radionuclide measurements (we are including total alpha determinations in the list) were QC-flagged for not meeting one or more of the data quality objectives. Table 6-5 provides comments for each analyte with QC flags. 
WSRC-TR-2003-00205, REVISION 0

SRT-RPP-2003-00086, REVISION 0

Table 6-5. QC Flags for Radionuclide Measurements on the Filtered Supernatant Phase of $\mathrm{AY}-102 / \mathrm{C}-106$

\begin{tabular}{|c|c|c|}
\hline \multicolumn{3}{|l|}{$\mathbf{Q C A C}=\mathbf{Q u}$} \\
\hline $\begin{array}{l}\text { Radio- } \\
\text { nuclide }\end{array}$ & QC Flag & Comments on QC Flag \\
\hline $\begin{array}{l}{ }^{3} \mathrm{H} \\
\text { (by counting) }\end{array}$ & $\mathrm{U}_{\mathrm{R}}$ & $\begin{array}{l}\text { One of the } 3 \text { analyses was slightly above the detection limit of liquid } \\
\text { scintillation counting whereas the other } 2 \text { analyses were below the } \\
\text { detection limit. The detection of }{ }^{3} \mathrm{H} \text { in one analysis (possibly from cross- } \\
\text { contamination from another sample) resulted in the QC flag because even } \\
\text { though a true RSD could not be calculated, it clearly could not meet the } \\
15 \% \text { QCO. }\end{array}$ \\
\hline $\begin{array}{l}{ }^{79} \mathrm{Se} \\
\text { (by counting) }\end{array}$ & $\mathrm{U}_{\mathrm{M}}$ & $\begin{array}{l}\text { The } \% \text { RSD of }{ }^{79} \mathrm{Se} \text { measurements was } 37 \% \text {, exceeding the } 15 \% \text { QCO. } \\
\text { The scatter in the data probably resulted from the extensive separation } \\
\text { chemistry required to isolate }{ }^{79} \text { Se from interfering radionuclides. }\end{array}$ \\
\hline${ }^{231} \mathrm{~Pa}$ & $\mathrm{U}_{\mathrm{M}}$ & $\begin{array}{l}\text { The detection limit for }{ }^{231} \mathrm{~Pa} \text { was }<1.2 \mathrm{E}-3 \text {, which exceeds by a factor of } \\
15 \text { the MRQ of } 7.9 \mathrm{E}-5 \text {. In order to meet this detection limit, a much } \\
\text { larger sample volume would have been required and the separation } \\
\text { chemistry performed in the shielded cell. }\end{array}$ \\
\hline $\begin{array}{l}{ }^{235} \mathrm{U} \\
\text { (by ICP-MS) }\end{array}$ & $\mathrm{U}_{\mathrm{L}}$ & $\begin{array}{l}\text { The \% recovery for the ICP-MS laboratory control standard was } 116 \% \text {, } \\
\text { higher than the QCO of } 85-115 \% \text {. }\end{array}$ \\
\hline $\begin{array}{l}{ }^{238} \mathrm{U} \\
\text { (by ICP-MS) }\end{array}$ & $\mathrm{U}_{\mathrm{S}}$ & $\begin{array}{l}\text { The \% recovery for the ICP-MS matrix spike was } 118 \% \text {, higher than the } \\
\text { QCO of } 85-115 \% \text {. }\end{array}$ \\
\hline${ }^{241} \mathrm{Am}$ & $\mathrm{U}_{\mathrm{B}}, \mathrm{U}_{\mathrm{R}}$ & $\begin{array}{l}\text { The blank }{ }^{241} \text { Am was about } 75 \% \text { of the average concentration measured } \\
\text { in the samples. The actual counts that resulted in this blank analysis was } \\
\text { about } 65 \mathrm{dpm} / \mathrm{mL} \text {. This level of contamination probably was introduced } \\
\text { in the shielded cell digestion. The RSD of } 3 \text { analyses was } 23 \% \text {, higher } \\
\text { than the } 15 \% \text { RSD in the QCO. With the blank measurement so high } \\
\text { relative to the actual sample, the scatter in precision is expected. }\end{array}$ \\
\hline $\begin{array}{l}{ }^{243 / 244} \mathrm{Cm} \\
\text { (by counting) }\end{array}$ & $\overline{U_{B}, U_{R}}$ & $\begin{array}{l}\text { The blank analysis for curium was nearly } 100 \% \text { of the measured values. } \\
\text { This level of contamination was introduced in the digestion in the } \\
\text { shielded cell. With the blank measurement at this level, the poor precision } \\
\text { of } 53 \% \text { RSD is plausible. }\end{array}$ \\
\hline $\begin{array}{l}\text { Total Alpha } \\
\text { (by counting) }\end{array}$ & $\mathrm{U}_{\mathrm{R}}$ & $\begin{array}{l}\text { The \% RSD was } 22 \text {, higher than QCO of } 15 \% \text { RSD. Imperfect separation } \\
\text { of high energy gamma and beta emitters is probably the cause of the } \\
\text { scatter. }\end{array}$ \\
\hline & & $\begin{array}{l}\mathrm{U}_{\mathrm{R}} \text { - fails \% RSD criteria } \\
\mathrm{U}_{\mathrm{L}} \text { - fails \% Recovery of LCS } \\
\text { N/A - not applicable }\end{array}$ \\
\hline
\end{tabular}




\subsection{COMPARISON OF MEASURED CHEMICAL ANALYTES IN AY-102/C-106 FILTERED SUPERNATANT VS. SPECIFICATION 7 FOR ENVELOPE A, B, AND C LOW-ACTIVITY WASTE}

As required by the Test Specification, certain analytes in the supernatant fraction must be converted to a mole basis, divided by the moles of $\mathrm{Na}$ in the supernatant, and then compared with the feed specifications for Low Activity Waste. The molarity of $\mathrm{Na}$ in the supernatant fraction is 3.24. Table 6-6 through Table 6-8 show for Low-Activity Envelopes A, B, and C, respectively, the $\%$ of maximum of the measured ratio and, in the far right column, declares whether the measured ratio meets the feed specification as per Specification 7. Total inorganic carbon (TIC) was $123 \%$ of the feed specification (for Envelopes A, B, and C) and is denoted in bold print in the table. Most other analytes were below the feed specifications by a wide margin, although the measured sulfate ratio was $67 \%$ of the maximum ratio allowed for Envelope A waste. 
Table 6-6. Comparison of Measured Chemical Analyte/Na Molar Ratios in AY-102/C-106 Supernatant Fraction vs. Maximum Chemical Analyte/Na Molar Ratios

(Per Specification 7 for Hanford Envelope A Low-Activity Waste) (Na Concentration in Supernatant Fraction is 3.24 M)

\begin{tabular}{|c|c|c|c|c|}
\hline $\begin{array}{l}\text { Chemical } \\
\text { Analyte }\end{array}$ & $\begin{array}{c}\text { Measured Moles } \\
\text { of Analyte/ } \\
\text { Moles of Na } \\
\text { Ratio }\end{array}$ & $\begin{array}{c}\text { Maximum Moles } \\
\text { of Analyte/ } \\
\text { Moles of Na } \\
\text { Ratio Per } \\
\text { Specification } 7 \\
\end{array}$ & $\begin{array}{c}\% \% \text { of } \\
\text { Maximum }\end{array}$ & $\begin{array}{c}\text { Does Measured } \\
\text { Moles of Analyte/ } \\
\text { Moles of Na Ratio } \\
\text { Meet } \\
\text { Specification 7? }\end{array}$ \\
\hline Al (ICP-AES) & $5.0 \mathrm{E}-2$ & $2.5 \mathrm{E}-1$ & $24 \%$ & Yes \\
\hline (ICP-AES) & $<1 \mathrm{E}-6$ & $1.0 \mathrm{E}-4$ & $<1 \%$ & Yes \\
\hline (ICP-AES) & $<5 \mathrm{E}-5$ & $4.0 \mathrm{E}-2$ & $<1 \%$ & Yes \\
\hline (ICP-AES) & $<3 \mathrm{E}-6$ & $4.0 \mathrm{E}-3$ & $<1 \%$ & Yes \\
\hline $\mathrm{Cl}^{-} \quad$ (IC) & $1.2 \mathrm{E}-3$ & $3.7 E-2$ & $3 \%$ & Yes \\
\hline $\mathrm{Cr}$ (ICP-AES) & $1.6 \mathrm{E}-3$ & $6.9 \mathrm{E}-3$ & $23 \%$ & Yes \\
\hline (IC) & $1.1 \mathrm{E}-3$ & $9.1 \mathrm{E}-2$ & $1 \%$ & Yes \\
\hline $\mathrm{Fe} \quad$ (ICP-AES) & $<1.2 \mathrm{E}-4$ & $1.0 \mathrm{E}-2$ & $<1 \%$ & Yes \\
\hline $\begin{array}{l}\mathrm{Hg} \quad \text { (AAS) } \\
\text { (used BWXT } \\
\text { determination) }\end{array}$ & $<1 \mathrm{E}-9$ & $1.4 \mathrm{E}-5$ & $<1 \%$ & Yes \\
\hline (AAS) & $3.2 \mathrm{E}-3$ & $1.8 \mathrm{E}-1$ & $2 \%$ & Yes \\
\hline $\mathrm{La} \quad$ (ICP-AES) & $<4.2 \mathrm{E}-6$ & $8.3 E-5$ & $<5 \%$ & Yes \\
\hline $\mathrm{Ni} \quad$ (ICP-AES) & $<1.8 \mathrm{E}-5$ & $3.0 \mathrm{E}-3$ & $<1 \%$ & Yes \\
\hline $\mathrm{NO}_{2}^{-}$ & $3.3 \mathrm{E}-2$ & $3.8 \mathrm{E}-1$ & $9 \%$ & Yes \\
\hline $\mathrm{NO}_{3}^{-}$ & $1.5 E-3$ & $8.0 \mathrm{E}-1$ & $<1 \%$ & Yes \\
\hline $\mathrm{Pb} \quad$ (ICP-AES) & $<1 \mathrm{E}-5$ & $6.8 E-4$ & $2 \%$ & Yes \\
\hline $\mathrm{PO}_{4}{ }^{-3}$ & $1.4 \mathrm{E}-2$ & $3.8 \mathrm{E}-2$ & $37 \%$ & Yes \\
\hline $\mathrm{SO}_{4}^{-2}$ & $6.7 E-3$ & $1.0 \mathrm{E}-2$ & $67 \%$ & Yes \\
\hline TIC & $3.7 \mathrm{E}-1$ & $3.0 \mathrm{E}-1$ & $123 \%$ & No \\
\hline TOC $\quad(\mathrm{CA})$ & $1.6 \mathrm{E}-1$ & $5.0 \mathrm{E}-1$ & $32 \%$ & Yes \\
\hline (ICP-AES) & $4.9 \mathrm{E}-5$ & $1.2 \mathrm{E}-3$ & $4 \%$ & Yes \\
\hline
\end{tabular}


Table 6-7. Comparison of Measured Chemical Analyte/Na Molar Ratios in AY-102/C-106 Supernatant Fraction vs. Maximum Chemical Analyte/Na Molar Ratios

(Per Specification 7 for Hanford Envelope B Low-Activity Waste) (Na Concentration in Supernatant Fraction is 3.24 M)

\begin{tabular}{|c|c|c|c|c|}
\hline $\begin{array}{l}\text { Chemical } \\
\text { Analyte }\end{array}$ & $\begin{array}{c}\text { Measured Moles } \\
\text { of Analyte/ } \\
\text { Moles of Na } \\
\text { Ratio }\end{array}$ & $\begin{array}{c}\text { Maximum Moles } \\
\text { of Analyte/ } \\
\text { Moles of Na } \\
\text { Ratio Per } \\
\text { Specification } 7 \\
\end{array}$ & $\begin{array}{c}\% \% \text { of } \\
\text { Maximum }\end{array}$ & $\begin{array}{c}\text { Does Measured } \\
\text { Moles of Analyte/ } \\
\text { Moles of Na Ratio } \\
\text { Meet } \\
\text { Specification 7? }\end{array}$ \\
\hline Al (ICP-AES) & $5.0 \mathrm{E}-2$ & $2.5 \mathrm{E}-1$ & $24 \%$ & Yes \\
\hline (ICP-AES) & $<1 \mathrm{E}-6$ & $1.0 \mathrm{E}-4$ & $<1 \%$ & Yes \\
\hline (ICP-AES) & $<5 \mathrm{E}-5$ & $4.0 \mathrm{E}-2$ & $<1 \%$ & Yes \\
\hline (ICP-AES) & $<3 \mathrm{E}-6$ & $4.0 \mathrm{E}-3$ & $<1 \%$ & Yes \\
\hline $\mathrm{Cl}^{-} \quad$ (IC) & $1.2 \mathrm{E}-3$ & $8.9 E-2$ & $1 \%$ & Yes \\
\hline $\mathrm{Cr}$ (ICP-AES) & $1.6 \mathrm{E}-3$ & $2.0 \mathrm{E}-2$ & $8 \%$ & Yes \\
\hline (IC) & $1.1 \mathrm{E}-3$ & $2.0 \mathrm{E}-1$ & $1 \%$ & Yes \\
\hline $\mathrm{Fe} \quad$ (ICP-AES) & $<1.2 \mathrm{E}-4$ & $1.0 \mathrm{E}-2$ & $<1 \%$ & Yes \\
\hline $\begin{array}{l}\mathrm{Hg} \quad \text { (AAS) } \\
\text { (used BWXT } \\
\text { determination) }\end{array}$ & $<1 \mathrm{E}-9$ & $1.4 \mathrm{E}-5$ & $<1 \%$ & Yes \\
\hline (AAS) & $3.2 \mathrm{E}-3$ & $1.8 \mathrm{E}-1$ & $2 \%$ & Yes \\
\hline $\mathrm{La} \quad$ (ICP-AES) & $<4.2 \mathrm{E}-6$ & $8.3 E-5$ & $<5 \%$ & Yes \\
\hline (ICP-AES) & $<1.8 \mathrm{E}-5$ & $3.0 \mathrm{E}-3$ & $<1 \%$ & Yes \\
\hline $\mathrm{NO}_{2}^{-}$ & $3.3 \mathrm{E}-2$ & $3.8 \mathrm{E}-1$ & $9 \%$ & Yes \\
\hline $\mathrm{NO}_{3}^{-}$ & $1.5 E-3$ & $8.0 \mathrm{E}-1$ & $<1 \%$ & Yes \\
\hline $\mathrm{Pb} \quad$ (ICP-AES) & $<1 \mathrm{E}-5$ & $6.8 E-4$ & $2 \%$ & Yes \\
\hline $\mathrm{PO}_{4}{ }^{-3}$ & $1.4 \mathrm{E}-2$ & $1.3 \mathrm{E}-1$ & $11 \%$ & Yes \\
\hline $\mathrm{SO}_{4}^{-2}$ & $6.7 E-3$ & $7.0 \mathrm{E}-2$ & $10 \%$ & Yes \\
\hline TIC & $3.7 \mathrm{E}-1$ & $3.0 \mathrm{E}-1$ & $123 \%$ & No \\
\hline TOC $\quad(\mathrm{CA})$ & $1.6 \mathrm{E}-1$ & $5.0 \mathrm{E}-1$ & $32 \%$ & Yes \\
\hline (ICP-AES) & $4.9 \mathrm{E}-5$ & $1.2 \mathrm{E}-3$ & $4 \%$ & Yes \\
\hline
\end{tabular}


Table 6-8. Comparison of Measured Chemical Analyte/Na Molar Ratios in AY-102/C-106 Supernatant Fraction vs. Maximum Chemical Analyte/Na Molar Ratios

(Per Specification 7 for Hanford Envelope C Low-Activity Waste) (Na Concentration in Supernatant Fraction is 3.24 M)

\begin{tabular}{|c|c|c|c|c|}
\hline $\begin{array}{c}\text { Chemical } \\
\text { Analyte }\end{array}$ & $\begin{array}{c}\text { Measured Moles } \\
\text { of Analyte/ } \\
\text { Moles of Na } \\
\text { Ratio }\end{array}$ & $\begin{array}{c}\text { Maximum Moles } \\
\text { of Analyte/ } \\
\text { Moles of Na } \\
\text { Ratio Per } \\
\text { Specification } 7 \\
\end{array}$ & $\begin{array}{c}\% \% \text { of } \\
\text { Maximum }\end{array}$ & $\begin{array}{c}\text { Does Measured } \\
\text { Moles of Analyte/ } \\
\text { Moles of Na Ratio } \\
\text { Meet } \\
\text { Specification 7? }\end{array}$ \\
\hline $\mathrm{Al} \quad$ (ICP-AES) & $5.0 \mathrm{E}-2$ & $2.5 \mathrm{E}-1$ & $24 \%$ & Yes \\
\hline $\mathrm{Ba} \quad$ (ICP-AES) & $<1 \mathrm{E}-6$ & $1.0 \mathrm{E}-4$ & $<1 \%$ & Yes \\
\hline (ICP-AES) & $<5 \mathrm{E}-5$ & $4.0 \mathrm{E}-2$ & $<1 \%$ & Yes \\
\hline (ICP-AES) & $<3 \mathrm{E}-6$ & $4.0 \mathrm{E}-3$ & $<1 \%$ & Yes \\
\hline $\mathrm{Cl}^{-} \quad$ (IC) & $1.2 \mathrm{E}-3$ & $3.7 \mathrm{E}-2$ & $3 \%$ & Yes \\
\hline $\mathrm{Cr} \quad$ (ICP-AES) & $1.6 \mathrm{E}-3$ & $6.9 E-3$ & $23 \%$ & Yes \\
\hline (IC) & $1.1 \mathrm{E}-3$ & $9.1 \mathrm{E}-2$ & $1 \%$ & Yes \\
\hline $\mathrm{Fe} \quad$ (ICP-AES) & $<1.2 \mathrm{E}-4$ & $1.0 \mathrm{E}-2$ & $<1 \%$ & Yes \\
\hline $\begin{array}{l}\mathrm{Hg} \quad \text { (AAS) } \\
\text { (used BWXT } \\
\text { determination) }\end{array}$ & $<1 \mathrm{E}-9$ & $1.4 E-5$ & $<1 \%$ & Yes \\
\hline (AAS) & $3.2 E-3$ & $1.8 \mathrm{E}-1$ & $2 \%$ & Yes \\
\hline $\mathrm{La} \quad$ (ICP-AES) & $<4.2 \mathrm{E}-6$ & $8.3 E-5$ & $<5 \%$ & Yes \\
\hline (ICP-AES) & $<1.8 \mathrm{E}-5$ & $3.0 \mathrm{E}-3$ & $<1 \%$ & Yes \\
\hline $\mathrm{NO}_{2}^{-}$ & $3.3 \mathrm{E}-2$ & $3.8 \mathrm{E}-1$ & $9 \%$ & Yes \\
\hline $\mathrm{NO}_{3}^{-}$ & $1.5 E-3$ & $8.0 \mathrm{E}-1$ & $<1 \%$ & Yes \\
\hline $\mathrm{Pb} \quad$ (ICP-AES) & $<1 \mathrm{E}-5$ & $6.8 E-4$ & $2 \%$ & Yes \\
\hline $\mathrm{PO}_{4}^{-3}$ & $1.4 \mathrm{E}-2$ & $3.8 \mathrm{E}-2$ & $38 \%$ & Yes \\
\hline $\mathrm{SO}_{4}^{-2}$ & $6.7 E-3$ & $2.0 \mathrm{E}-2$ & $34 \%$ & Yes \\
\hline TIC & $3.7 \mathrm{E}-1$ & $3.0 \mathrm{E}-1$ & $123 \%$ & No \\
\hline TOC $\quad(\mathrm{CA})$ & $1.6 \mathrm{E}-1$ & $5.0 \mathrm{E}-1$ & $32 \%$ & Yes \\
\hline U (ICP-AES) & $4.9 E-5$ & $1.2 \mathrm{E}-3$ & $4 \%$ & Yes \\
\hline
\end{tabular}




\subsection{COMPARISON OF MEASURED RADIONUCLIDES AY-102/C-106 FILTERED SUPERNATANT FRACTION VERSUS SPECIFICATION 7 FOR ENVELOPE A, B, AND C LOW-ACTIVITY WASTE}

Certain radionuclide determinations in the supernatant fraction must be converted to a Becquerel basis (disintegrations/second), divided by the moles of $\mathrm{Na}$ in the supernatant, and then compared with the feed specifications for Hanford Envelope A, B, and C Low-Activity Waste. The molarity of $\mathrm{Na}$ in the supernatant fraction is 3.24. Table 6-9 through Table 6-11 show for Envelope A, B, and C, respectively, the percent of maximum of the measured ratio and, in the far right column, state whether the measured ratio meets the feed specification per Specification 7. The sum of measured transuranic (TRU) isotopes was $4.9 \mathrm{E}+5$ Becquerels/mole of $\mathrm{Na}$, exceeding the maximum allowed Becquerels of TRU/mole of $\mathrm{Na}$ of $4.8 \mathrm{E}+5$ for Envelope A and Envelope B low-activity waste by about $2 \%$. Since the measured TRU concentration exceeds the maximum allowed concentration for Envelope A and Envelope B waste, it is denoted by bold print in Table 6-9 and Table 6-10, respectively. The uncertainties in each TRU measurement mean that the measured and maximum values are within experimental error. The TRU values may be biased high by the cross-contamination of ${ }^{244} \mathrm{Cm}$ introduced in the sample preparation step performed in the shielded cells. The level of ${ }^{244} \mathrm{Cm}$ contamination in the blank would contribute about $5 \%$ to the TRU measurements. The TRU measurements of the AY-102/C-106 supernatant phase would have been below the maximum permitted concentrations for Envelope A and Envelope B Low-Activity Waste if the ${ }^{244} \mathrm{Cm}$ contamination is taken into account. The other measured radionuclide concentrations are below the maximum permitted concentrations for Envelope A, B, and C Low-Activity Waste.

Table 6-9. Comparison of Measured Becquerels of Radionuclide per Mole of Na in Supernatant Fraction vs. Maximum Becquerels of Radionuclide per Mole of Na

(Per Specification 7 for Hanford Envelope A Low-Activity Waste) (Na Concentration in Supernatant Fraction is 3.24 M)

\begin{tabular}{|c|c|c|c|c|}
\hline Radionuclide & $\begin{array}{c}\text { Measured } \\
\text { Becquerels of } \\
\text { Radionuclide/ } \\
\text { Mole of Na }\end{array}$ & $\begin{array}{c}\text { Maximum } \\
\text { Becquerels of } \\
\text { Radionuclide/ } \\
\text { Mole of Na Per } \\
\text { Specification 7 }\end{array}$ & $\begin{array}{c}\text { Does Measured } \\
\text { Becquerels of } \\
\text { Radionuclide / } \\
\text { Maximum }\end{array}$ & $\begin{array}{c}\text { Mole of Na Meet } \\
\text { Specification 7? }\end{array}$ \\
\hline TRU & $\mathbf{4 . 9}$ E $+\mathbf{5}$ & $\mathbf{4 . 8 ~ E + 5}$ & $\mathbf{1 0 2 \%}$ & No \\
\hline${ }^{137} \mathrm{Cs}$ & $3.2 \mathrm{E}+8$ & $4.3 \mathrm{E}+9$ & $7 \%$ & Yes \\
\hline${ }^{90} \mathrm{Sr}$ & $2.0 \mathrm{E}+7$ & $4.4 \mathrm{E}+7$ & $45 \%$ & Yes \\
\hline${ }^{99} \mathrm{Tc}$ & $1.4 \mathrm{E}+5$ & $7.1 \mathrm{E}+6$ & $2 \%$ & Yes \\
\hline${ }^{60} \mathrm{Co}$ & $1.8 \mathrm{E}+4$ & $6.1 \mathrm{E}+4$ & $30 \%$ & Yes \\
\hline${ }^{154} \mathrm{Eu}$ & $2.9 \mathrm{E}+3$ & $1.2 \mathrm{E}+6$ & $<1 \%$ & Yes \\
\hline
\end{tabular}


Table 6-10. Comparison of Measured Becquerels of Radionuclide per Mole of Na in Supernatant Fraction vs. Maximum Becquerels of Radionuclide per Mole of $\mathrm{Na}$

(Per Specification 7 for Hanford Envelope B Low-Activity Waste)

(Na Concentration in Supernatant Fraction is 3.24 M)

\begin{tabular}{|c|c|c|c|c|}
\hline Radionuclide & $\begin{array}{c}\text { Measured } \\
\text { Becquerels of } \\
\text { Radionuclide/ } \\
\text { Mole of Na }\end{array}$ & $\begin{array}{c}\text { Maximum } \\
\text { Becquerels of } \\
\text { Radionuclide/ } \\
\text { Mole of Na Per } \\
\text { Specification 7 }\end{array}$ & $\begin{array}{c}\text { Does Measured } \\
\text { Maximum } \\
\text { Becquerels of } \\
\text { Radionuclide / } \\
\text { Mole of Na Meet } \\
\text { Specification 7? }\end{array}$ \\
\hline TRU & $\mathbf{4 . 9} \mathbf{E}+\mathbf{5}$ & $\mathbf{4 . 8} \mathbf{E}+\mathbf{5}$ & $\mathbf{1 0 2 \%}$ & No \\
\hline${ }^{137} \mathrm{Cs}$ & $3.2 \mathrm{E}+8$ & $2.0 \mathrm{E}+10$ & $2 \%$ & Yes \\
\hline${ }^{90} \mathrm{Sr}$ & $2.0 \mathrm{E}+7$ & $4.4 \mathrm{E}+7$ & $45 \%$ & Yes \\
\hline${ }^{99} \mathrm{Tc}$ & $1.4 \mathrm{E}+5$ & $7.1 \mathrm{E}+6$ & $2 \%$ & Yes \\
\hline${ }^{60} \mathrm{Co}$ & $1.8 \mathrm{E}+4$ & $6.1 \mathrm{E}+4$ & $30 \%$ & Yes \\
\hline${ }^{154} \mathrm{Eu}$ & $2.9 \mathrm{E}+3$ & $1.2 \mathrm{E}+6$ & $<1 \%$ & Yes \\
\hline
\end{tabular}

Table 6-11. Comparison of Measured Becquerels of Radionuclide per Mole of Na in Supernatant Fraction vs. Maximum Becquerels of Radionuclide per Mole of $\mathrm{Na}$

(Per Specification 7 for Hanford Envelope C Low-Activity Waste)

(Na Concentration in Supernatant Fraction is 3.24 M)

\begin{tabular}{|c|c|c|c|c|}
\hline Radionuclide & $\begin{array}{c}\text { Measured } \\
\text { Becquerels of } \\
\text { Radionuclide/ } \\
\text { Mole of Na }\end{array}$ & $\begin{array}{c}\text { Maximum } \\
\text { Becquerels of } \\
\text { Radionuclide/ } \\
\text { Mole of Na Per } \\
\text { Specification 7 }\end{array}$ & $\begin{array}{c}\text { Does Measured } \\
\text { Mecquerels of } \\
\text { Maximum } \\
\text { Radionuclide / } \\
\text { Mole of Na Meet } \\
\text { Specification 7? }\end{array}$ \\
\hline${ }_{\mathrm{TRU}}$ & $4.9 \mathrm{E}+5$ & $3.0 \mathrm{E}+6$ & $16 \%$ & Yes \\
\hline${ }^{137} \mathrm{Cs}$ & $3.2 \mathrm{E}+8$ & $4.3 \mathrm{E}+9$ & $7 \%$ & Yes \\
\hline${ }^{90} \mathrm{Sr}$ & $2.0 \mathrm{E}+7$ & $8.0 \mathrm{E}+8$ & $3 \%$ & Yes \\
\hline${ }^{99} \mathrm{Tc}$ & $1.4 \mathrm{E}+5$ & $7.1 \mathrm{E}+6$ & $2 \%$ & Yes \\
\hline${ }^{60} \mathrm{Co}$ & $1.8 \mathrm{E}+4$ & $3.7 \mathrm{E}+5$ & $5 \%$ & Yes \\
\hline${ }^{154} \mathrm{Eu}$ & $2.9 \mathrm{E}+3$ & $4.3 \mathrm{E}+6$ & $<1 \%$ & Yes \\
\hline
\end{tabular}




\subsection{CHEMICAL AND RADIONUCLIDE ANALYSIS OF THE SOLID FRACTION FROM AY-102/C-106}

\subsection{SOLIDS FRACTION PRETREATMENT PRIOR TO ANALYSES}

The wet solids in the slurry were separated from the supernatant fraction by using a benchtop centrifuge to spin the samples at approximately $8000 \mathrm{rpm}$ for one hour in $30-\mathrm{mL}$ Teflon centrifuge tubes. The supernatant fraction was decanted and used for subsequent analyses on this fraction. The wet solids remaining in the tube were immediately weighed to obtain the weight required for reporting analytes on a wet solids basis. We chose to use $5-\mathrm{mL}$ aliquots of the as-received slurry to yield approximately $1.25 \mathrm{~g}$ of wet solids, a convenient amount of solids for digestions. This experimental technique avoided possible errors such as sludge heterogeneity and weighing out the wet sludge by transfer techniques. However, this approach did require a modicum of care in the centrifugation step to ensure that the relative amount of solid and interstitial supernatant was reasonably consistent. Poor execution of this step would have manifested itself in large variations of the $\mathrm{Na} / \mathrm{Fe}$ ratio (which we did not see). The simple safeguard of using reasonably consistent amounts of slurry and wet solids for digestion and subsequent analyses led to good overall analytical precision for the solids and liquid fractions.

The wet solids fractions were treated with four different techniques to provide solutions suitable for the various instrumental analysis techniques.

\subsubsection{Warm Water Leach}

The purpose of the warm water leach was to provide a solution suitable for measuring the water-soluble anions, total inorganic carbon, and total organic carbon in the wet sludge. The method used was an adaptation of the Hanford method.

Digestion Method Reference: Analytical Services Procedure: LA-504-101, "Water Leach Sample Preparation," Rev-Mod H-0, issued, 10/16/2001, Authors: B.Griffin,II and J.M. Frye.

This procedure uses an ultrasonic bath to agitate and help separate soluble components from the insoluble sludge. SRTC did not have an ultrasonic bath in the cell used for the AY-102/ C-106 characterization. Therefore, a warm water leach was used to similar effect. The wet solids were treated with $25 \mathrm{~mL}$ de-ionized water for 3 hours at $75^{\circ} \mathrm{C}$ in the original Teflon centrifuge tube used to separate solid from supernatant. The mixture was then filtered through a $0.45 \mu \mathrm{m}$ filter. The filter was washed twice with $10-\mathrm{mL}$ portions of de-ionized water. The filtrate was transferred to a $50-\mathrm{mL}$ volumetric flask for final dilution with de-ionized water. This procedure was used to measure water-soluble anions, total inorganic carbon, and total organic carbon. The warm water leach method was used to extract the interstitial supernatant in the solids and the analytes in the solid phase with higher solubility in the dilute caustic solution than in the high-caustic matrix of the as-received solids. 
The exact weights of the wet solids used for the three digestions were:
Trial $1=1.157 \mathrm{~g}$
Trial $2=1.379 \mathrm{~g}$
Trial $3=1.371 \mathrm{~g}$

The warm water leach of the solids was performed in triplicate on the wet AY-102 solids. In addition, a reagent blank digestion was performed as part of the QC protocol on the AY-102/ C-106 solids. Analyses of laboratory control standards and matrix spikes were performed in the instrumental analysis laboratories for additional QC.

\subsubsection{Hot Aqua Regia Digestion}

The wet solids were dissolved with aqua regia $\left(3: 1\right.$, v/v, concentrated $\mathrm{HCl} /$ concentrated $\left.\mathrm{HNO}_{3}\right)$ using the SRTC method.

Digestion Method Reference: Analytical Development Section Procedure -ADS 2226, “Aqua Regia Dissolution of Sludge for Elemental Analysis," Rev.6, issued 2/27/2003, Author: C.J. Coleman.

This dissolution was used to produce solutions for ICP-AES, AAS, ICP-MS, and radiochemistry determinations. The wet sludge was transferred to Teflon pressure vessels and sealed prior to heating for carrying out the digestions under elevated temperature and pressure. After heating and cooling to room temperature, the acid solution was diluted to $100 \mathrm{~mL}$. These solutions had a dose rate of about $25 \mathrm{millirem} / \mathrm{hr}$ at $30 \mathrm{cms}$, which exceeded the radiation dose limits (10 millirem/hr at $30 \mathrm{cms} ; 1000 \mathrm{millirem} / \mathrm{hr}$ extremity) for work in SRTC unshielded hoods and were subsequently diluted another 10 -fold prior to analysis to yield a final effective dilution volume of $1000 \mathrm{~mL}$.

The exact weight of wet solids used for the three aqua regia digestions were:

Trial $1=1.252 \mathrm{~g} \quad$ Trial $2=1.230 \mathrm{~g} \quad$ Trial $3=1.228 \mathrm{~g}$

Limitations of this method include possible incomplete dissolution of $\mathrm{Si}$ and $\mathrm{Zr}$ compounds in the waste. Also, the $\mathrm{Na}$ value from this method was significantly lower compared with the $\mathrm{Na}$ value from the $\mathrm{KOH}$ fusion method. (See discussion in Section 7.1.4 on using a third acid digestion to help settle on the reported Na concentration in the AY-102/C-106 solids.)

The hot aqua regia digestion was performed in triplicate on the wet AY-102/C-106 solids. In addition, a blank digestion (reagent blank) and a digestion on the Analytical Reference Glass-1 were also performed as part of the QC protocol on the AY-102/C-106 samples. Although the Analytical Reference Glass-1 is not the same matrix as the high-level sludge, it has some of the same elements and can be used to gauge analytical accuracy of elemental analyses. The hot aqua regia digestion leaches out most of the glass components from the silica framework to yield a solution suitable for ICP-AES and AAS analyses. This QC technique helps check for gravimetric and dilution errors in the digestion step, and also checks for instrumental errors in ICP-AES and AAS analyses. Laboratory control standards and matrix spikes were analyzed in the instrumental analysis laboratories for additional QC. 


\subsubsection{KOH/KNO $/ \mathrm{Fusion}$}

The wet solids in three centrifuge tubes $(1.257 \mathrm{~g}, 1.248 \mathrm{~g}$, and $1.254 \mathrm{~g}$ of wet solids for Trial 1 , 2 , and 3 , respectively) were first dried to constant weight at $115^{\circ} \mathrm{C}$ to produce a dry material suitable for an alkali fusion technique. The pellet of dry solid was then quantitatively transferred to a $\mathrm{Zr}$ crucible for digestion with $\mathrm{KOH} / \mathrm{KNO}_{3}$ fusion followed by dissolution of the fusion residue with sequential additions of de-ionized water and concentrated $\mathrm{HCl}$ and final dilution to $1000 \mathrm{~mL}$. We used the Hanford 222-S Laboratory alkali fusion method with minimal modifications

Digestion Method Reference: Analytical Services Procedure-LA-549-141, Rev-Mod G-3, issued 7/19/2001,Authors: H.L Anastos and S.A. Catlow.

The exact weights of dry solids transferred into $\mathrm{Zr}$ crucibles for the three $\mathrm{KOH} / \mathrm{KNO}_{3}$ fusion digestions were:
Trial $1=0.581 \mathrm{~g}$
Trial $2=0.587 \mathrm{~g}$
Trial $3=0.576 \mathrm{~g}$

The fusion digestions were used for elemental analyses by ICP-AES and ICP-MS techniques. This digestion method is also suitable for measuring most non-volatile radionuclides. However, we chose to measure most radionuclides only on the hot aqua regia digestions because of cost and schedule considerations. The ${ }^{151} \mathrm{Sm}$ in the solid fraction was measured on the $\mathrm{KOH} / \mathrm{KNO}_{3}$ fusion digestions because the hot aqua regia digestion solutions were consumed when the ${ }^{151} \mathrm{Sm}$ determinations were made.

Limitations of this method include loss of volatile components and inability to measure $\mathrm{K}$ and the fusion crucible material, which in this case was $\mathrm{Zr}$.

A reagent blank digestion and a digestion on the Analytical Reference Glass-1 were performed as part of the QC protocol on the AY-102/C-106 samples. Although the Analytical Reference Glass- 1 is not the same matrix as the high-level sludge, it can be used to gauge analytical accuracy of elemental analyses. The $\mathrm{KOH} / \mathrm{KNO}_{3}$ fusion completely dissolves the Analytical Reference Glass-1 to yield a solution suitable for ICP-AES and AAS analyses. This QC technique helps check for gravimetric and dilution errors in the digestion step, and also checks for instrumental errors in ICP-AES and AAS analyses. Laboratory control standards and matrix spikes were analyzed in the instrumental analysis laboratories for additional QC.

\subsubsection{Hot $\mathrm{HF}-\mathrm{HNO}_{3}-\mathrm{HCl}-\mathrm{H}_{3} \mathrm{BO}_{3}$ Digestion}

The wet solids were dissolved with a hot mixture of $\mathrm{HF}-\mathrm{HNO} \mathrm{O}_{3}-\mathrm{HCl}-\mathrm{H}_{3} \mathrm{BO}_{3}$ in a sealed Teflon vessel using a slight modification of the ADS method.

Digestion Method Reference: Analytical Development Section Procedure: ADS-2227, “Acid Dissolution of Glass and Sludge for Elemental Analysis," Rev.7, issue date 1/30/2003, Author: C.J. Coleman. 
$500 \mathrm{~mL}$ of $0.6 \mathrm{M} \mathrm{H}_{3} \mathrm{BO}_{3}$ was then added to help complex the excess HF. De-ionized water was used to dilute the solution to a final volume of $1000 \mathrm{~mL}$. This method was used primarily to measure $\mathrm{Zr}$ in the sludge and to serve as a referee to resolve the difference in $\mathrm{Na}$ measurements from the hot aqua regia digestions and the $\mathrm{KOH}$ fusion digestions. The $\mathrm{Na}$ determinations from this digestion agreed more closely with the Na determinations from the $\mathrm{KOH}$ fusion digestion when the weight \% total solids factor was applied.

The exact weights of the wet solids used for the three digestions were:

Trial $1=1.335 \mathrm{~g} \quad$ Trial $2=1.348 \mathrm{~g} \quad$ Trial $3=1.220 \mathrm{~g}$

Limitations of this method include possible formation of insoluble fluorides, effects on the ICP-AES nebulizer/spray chamber assembly that can produce high-biased Si determinations, and inability to measure $\mathrm{B}$ because of the $\mathrm{H}_{3} \mathrm{BO}_{3}$ addition. Note that fewer analytes were measured with this digestion (only the routine ICP-AES elements reported by the SRTC ICP-AES laboratory) because of the limited use of this digestion method.

The $\mathrm{HF}-\mathrm{HNO}_{3}-\mathrm{HCl}-\mathrm{H}_{3} \mathrm{BO}_{3}$ digestion was performed in triplicate on the wet AY-102 solids. In addition, a reagent blank digestion was performed as part of the QC protocol on the AY-102/ C-106 samples. The Analytical Reference Glass-1 standard was not dissolved with this method as part of the QC protocol. Laboratory control standards and matrix spikes were analyzed in the instrumental analysis laboratories for additional QC.

\subsection{CHEMICAL ANALYSES OF THE SOLIDS FRACTION FROM AY-102/C-106}

ADS general instrumental analysis methods were applied to the solids fraction from AY-102/ $\mathrm{C}-106$. In many cases, specific instructions for analyzing the solid samples were supplied by ADS chemists. Additional QA/QC used for these samples included the concurrent analyses of blanks, laboratory control standards, and matrix spikes stipulated in the Test Specification. Table 7-1 lists the instrumental method including the ADS procedure reference, and the analytes in the AY-102/C-106 solid fraction measured with these methods. Our abbreviation of the method is included in parentheses and this same abbreviation is also used in the data tables. 
Table 7-1. Instrumental Analysis Methods Used for Analyzing AY-102/C-106 Solid Fraction

\begin{tabular}{|c|c|c|c|}
\hline Analytical Method & $\begin{array}{c}\text { ADS } \\
\text { Method } \\
\text { Number }\end{array}$ & $\begin{array}{l}\text { Issue or } \\
\text { Last Rev } \\
\text { Date }\end{array}$ & $\begin{array}{l}\text { Analytes Measured } \\
\text { With This Method }\end{array}$ \\
\hline $\begin{array}{l}\text { Ion Chromatography (IC) } \\
\text { "Analysis of Solutions by Ion } \\
\text { Chromatography" }\end{array}$ & 2306 & $1 / 30 / 98$ & $\begin{array}{l}\mathrm{NO}_{3}{ }^{-}, \mathrm{NO}_{2}^{-}, \mathrm{PO}_{4}{ }^{3-}, \mathrm{SO}_{4}{ }^{2-} \\
\mathrm{C}_{2} \mathrm{O}_{4}{ }^{2-}, \mathrm{Cl}^{-}, \mathrm{Br}^{-}, \mathrm{F}^{-}, \mathrm{CHO}_{2}{ }^{-}\end{array}$ \\
\hline $\begin{array}{l}\text { Carbon Analyzer by Furnace } \\
\text { Oxidation (CA) } \\
\text { "DC-190 High Temperature TOC } \\
\text { Analyzer with Remote Sampling Bay" }\end{array}$ & 2255 & $1 / 31 / 99$ & $\begin{array}{l}\text { total inorganic carbon, } \\
\text { total organic carbon }\end{array}$ \\
\hline $\begin{array}{l}\text { Inductively Coupled Plasma-Atomic } \\
\text { Emission Spectroscopy (ICP-AES) } \\
\text { "Contained Inductively Coupled } \\
\text { Plasma Emission Spectrometer" }\end{array}$ & 1564 & $9 / 27 / 01$ & $\begin{array}{l}\mathrm{Ag}, \mathrm{Al}, \mathrm{B}, \mathrm{Ba}, \mathrm{Be}, \mathrm{Ca}, \mathrm{Cr}, \\
\mathrm{Fe}, \mathrm{La}, \mathrm{Li}, \mathrm{Mg}, \mathrm{Mn}, \mathrm{Na}, \\
\mathrm{Ni}, \mathrm{P}, \mathrm{S}, \mathrm{Si}, \mathrm{Sr}, \mathrm{Ti}, \mathrm{V}, \mathrm{Zn}, \\
\mathrm{Zr}\end{array}$ \\
\hline $\begin{array}{l}\text { Inductively Coupled Plasma-Mass } \\
\text { Spectrometry (ICP-MS) } \\
\text { "Inductively Coupled Plasma- Mass } \\
\text { Spectrometer" }\end{array}$ & 1543 & $9 / 15 / 02$ & $\begin{array}{l}\text { Ag, } \mathrm{Bi}, \mathrm{Cd}, \mathrm{Ce}, \mathrm{Co}, \\
{ }_{133,135} \mathrm{Cs} \text { (contributing } \\
\text { along with }{ }^{137} \mathrm{Cs} \text { from } \\
\text { counting to total } \mathrm{Cs}), \mathrm{Cu}, \\
\mathrm{Nd}, \mathrm{Pb}, \mathrm{Pr}, \mathrm{Pt}, \mathrm{Rb}, \mathrm{Rh}, \\
\mathrm{Ru}, \mathrm{Ta}, \mathrm{Te}, \mathrm{Th}, \mathrm{Tl}, \mathrm{U}, \mathrm{W}, \\
\mathrm{Y}\end{array}$ \\
\hline $\begin{array}{l}\text { Atomic Absorption Spectrometry } \\
\text { (AAS) } \\
\text { "Procedure for Vapor/Hydride } \\
\text { Generation Atomic Absorption," }\end{array}$ & 1557 & $12 / 15 / 02$ & $\mathrm{As}, \mathrm{Hg}, \mathrm{Se}$ \\
\hline $\begin{array}{l}\text { Atomic Absorption Spectrometry } \\
\text { (AAS) } \\
\text { "Procedure for Operating the Varian } \\
\text { Spectraa-880 Atomic Absorption } \\
\text { Spectrometer," }\end{array}$ & 1554 & $12 / 15 / 02$ & $\mathrm{~K}$ \\
\hline
\end{tabular}




\subsection{ANION, TIC/TOC, AMMONIA ANALYSES OF THE SOLIDS FRACTION FROM AY-102/C-106}

Anion and TIC/TOC data for the as-received AY-102/C-106 solids are displayed in Table 7-2. The sample preparation technique was the warm water leach (except for $\mathrm{NH}_{3}$ and $\mathrm{CN}^{-}$ measurements that were performed by BWXT directly on wet solids without the warm water leach pretreatment). Solutions resulting from the warm water leach were then analyzed by ion chromatography methods to measure anions. Solutions were also analyzed by high temperature oxidation techniques for TIC/TOC. Since the composition of the wet solids is over $50 \%$ interstitial supernatant, the anion and TIC/TOC data would be expected to be proportionately lower than measured in the supernatant fraction. This expectation is borne out for most measurements, but notable exceptions to this trend include fluoride and bromide that actually have higher concentrations on a $\mathrm{mg} / \mathrm{kg}$ basis in the solids than on a $\mathrm{mg} / \mathrm{L}$ basis in the supernatant fraction. Apparently the lower caustic content of the warm water leach dissolved fluoride and bromide compounds in the solids fraction. Note that this warm water leach approach does not preclude the possibility that water-insoluble anions would not be measured.

Measuring TOC on high-level sludge is frequently problematical at SRTC. The activity of the sludge precludes removal of more than a few mg of undiluted material from the shielded cells. The precision of TOC determinations may be poor because of difficulties with introducing a heterogeneous solid sample into the TOC oxidation chamber. Because of these technical difficulties, SRTC was unable to make a direct TOC measurement on the AY-102/C-106 sludge. Our approach was to use a large dilution with warm de-ionized water to extract the soluble organic complexants (oxalate, acetate, formate, citrate) into a solution for TOC analysis. The decreased salt content of the warm water leach also helps to increase the inherent solubility of semi-volatile organic compounds in the waste. However, this technique would not capture any truly insoluble organic species such as plastics and other polymeric materials or any completely water insoluble complexants in the waste. Therefore, the measurement performed was not strictly a TOC measurement on the entire wet solid sample, but a measurement of TOC on the warm water leachate of the solid fraction, as is indicated in Table 7-2. 
Table 7-2. Anion, TIC/TOC, and Ammonia Composition of the As-Received AY-102/C-106 Solids Fraction Following a Warm Water Leach to Separate the Water-Soluble Analytes from the Solids and Dilution To $50 \mathrm{~mL}$

Concentrations are on a Wet Solids (after Centrifugation) Basis

\begin{tabular}{|c|c|c|c|c|c|c|c|c|c|}
\hline Analyte & $\begin{array}{c}1^{\text {st }} \\
\text { Analysis } \\
(\mathrm{mg} / \mathrm{kg})\end{array}$ & $\begin{array}{c}2^{\text {nd }} \\
\text { Analysis } \\
(\mathrm{mg} / \mathrm{kg})\end{array}$ & $\begin{array}{c}3^{\text {rd }} \\
\text { Analysis } \\
(\mathrm{mg} / \mathrm{kg})\end{array}$ & $\begin{array}{l}\text { Average } \\
\text { Analysis } \\
(\mathrm{mg} / \mathrm{kg})\end{array}$ & $\begin{array}{c}\text { RSD } \\
(\%) \\
\end{array}$ & $\begin{array}{c}\text { Blank } \\
\text { Analysis } \\
\text { (mg/kg) }\end{array}$ & $\begin{array}{c}\text { LCS } \\
\text { Recov. } \\
(\%)\end{array}$ & $\begin{array}{c}\text { MS } \\
\text { Recov. } \\
(\%)\end{array}$ & $\begin{array}{c}\text { QC } \\
\text { Flag } \\
\end{array}$ \\
\hline $\mathrm{NO}_{3}^{-} \quad$ (IC) & 237 & 216 & 215 & 223 & $6 \%$ & $<10$ & $98 \%$ & $89 \%$ & - \\
\hline $\mathrm{NO}_{2}^{-} \quad$ (IC) & 2,180 & 1,690 & 2,020 & 1,960 & $13 \%$ & $<10$ & $99 \%$ & $98 \%$ & - \\
\hline $\mathrm{PO}_{4}^{-3} \quad$ (IC) & 1,010 & 920 & 808 & 910 & $11 \%$ & $<10$ & $98 \%$ & $90 \%$ & - \\
\hline $\mathrm{SO}_{4}^{-2} \quad$ (IC) & 976 & 866 & 972 & 938 & $7 \%$ & $<5$ & $98 \%$ & $89 \%$ & - \\
\hline $\mathrm{C}_{2} \mathrm{O}_{4}^{-2}$ (IC) & 2,340 & 2,030 & 2,120 & 2,160 & $7 \%$ & $<10$ & $100 \%$ & $91 \%$ & - \\
\hline $\mathrm{Cl}^{-} \quad$ (IC) & 140 & 140 & 140 & 140 & $0 \%$ & $<2$ & $103 \%$ & $97 \%$ & - \\
\hline $\mathrm{F}^{-} \quad(\mathrm{IC})$ & 560 & 465 & 314 & 446 & $28 \%$ & $<2$ & $102 \%$ & $93 \%$ & $\mathrm{U}_{\mathrm{R}}$ \\
\hline $\mathrm{Br}^{-} \quad$ (IC) & 264 & 111 & 210 & 195 & $39 \%$ & $<10$ & $97 \%$ & $95 \%$ & $\mathrm{U}_{\mathrm{R}}$ \\
\hline $\mathrm{CHO}_{2}^{-}$(IC) & 123 & 93 & 90 & 102 & $18 \%$ & $<10$ & $100 \%$ & $91 \%$ & $\mathrm{U}_{\mathrm{R}}$ \\
\hline TIC (CA) & 7,870 & 9,390 & 8,970 & 8,740 & $9 \%$ & 68 & $100 \%$ & $95 \%$ & - \\
\hline TOC (CA) & 7,520 & 5,180 & 3,210 & 5,300 & $41 \%$ & 1,600 & $100 \%$ & $95 \%$ & $\mathrm{U}_{\mathrm{R}} \mathrm{U}_{\mathrm{B}}$ \\
\hline $\begin{array}{l}\mathrm{NH}_{3} \text { (BWXT) } \\
\text { (analysis } \\
\text { performed on } \\
\text { untreated wet } \\
\text { solids) }\end{array}$ & $<87$ & $<99$ & $<85$ & $<99$ & $\mathrm{~N} / \mathrm{A}$ & $<0.2$ & $98 \%$ & $92 \%$ & - \\
\hline $\begin{array}{l}\mathrm{CN}^{-} \text {(BWXT) } \\
\text { (analysis } \\
\text { performed on } \\
\text { untreated wet } \\
\text { solids) }\end{array}$ & 14 & 13 & 13 & 13 & $3 \%$ & 0.005 & $105 \%$ & $103 \%$ & - \\
\hline $\begin{array}{l}\text { QC Flags: - - } m \\
\mathrm{U}_{\mathrm{B}} \text { - blank exce } \\
\mathrm{U}_{\mathrm{O}} \text { - Outlier omi }\end{array}$ & $\begin{array}{l}\text { eets all QC } \\
\text { eds } 5 \% \text { of san } \\
\text { ted in reporte }\end{array}$ & average ana & $\begin{array}{l}U_{R} \\
U_{L} \\
N / A\end{array}$ & $\begin{array}{l}\text { ls \% RSD c } \\
\text { ls \% Recov } \\
\text { ot applicabl }\end{array}$ & ia & \multicolumn{4}{|c|}{$\begin{array}{l}U_{M} \text { - fails min. reportable quantity } \\
U_{S} \text { - fails \% Recovery of MS }\end{array}$} \\
\hline
\end{tabular}




\subsection{ANION, TIC/TOC, AND AMMONIA ANALYSES OF THE SOLIDS FRACTION FROM AY-102/C-106 ON BOTH WET SOLIDS AND DRY SOLIDS BASIS}

As stipulated by the Test Specification, the composition of the solids fraction is to be reported on both a wet basis and a dry basis. To convert the wet basis concentrations to dry basis concentrations, the weight $\%$ dry solids in the wet solids fraction, $45.5 \%$, was used to obtain the conversion factor of 2.2. To facilitate comparison, both the wet solids basis concentrations and dry solids basis concentrations are included in Table 7-3.

Table 7-3. Anion, TIC/TOC, and Ammonia Composition of the As-Received AY-102/C106 Solids Following a Warm Water Leach and Dilution to $50 \mathrm{~mL}$ on Both Wet Solids Basis and Dry Solids Basis

Comparison of Wet and Dry Basis Concentrations of Analytes

Wet to Dry Solids Conversion Factor is 2.2

\begin{tabular}{|c|c|c|c|c|}
\hline \multicolumn{2}{|c|}{ Analyte } & \multirow{2}{*}{$\begin{array}{c}\begin{array}{c}\text { Average Analysis on Wet } \\
\text { Solids Basis } \\
\text { (mg/kg) }\end{array} \\
223\end{array}$} & \multirow{2}{*}{$\begin{array}{c}\begin{array}{c}\text { Average Analysis on Dry } \\
\text { Solids Basis (mg/kg) }\end{array} \\
491\end{array}$} & \multirow{2}{*}{$\begin{array}{c}\text { QC Flag } \\
-\end{array}$} \\
\hline $\mathrm{NO}_{3}^{-}$ & (IC) & & & \\
\hline $\mathrm{NO}_{2}^{-}$ & (IC) & 1,960 & 4,310 & - \\
\hline $\mathrm{PO}_{4}{ }^{3-}$ & (IC) & 910 & 2,000 & - \\
\hline $\mathrm{SO}_{4}{ }^{2-}$ & (IC) & 938 & 2,060 & - \\
\hline $\mathrm{C}_{2} \mathrm{O}_{4}{ }^{2-}$ & (IC) & 2,160 & 4,750 & - \\
\hline $\mathrm{Cl}^{-}$ & (IC) & 140 & 308 & - \\
\hline $\mathrm{F}^{-}$ & (IC) & 446 & 981 & $\mathrm{U}_{\mathrm{R}}$ \\
\hline $\mathrm{Br}^{-}$ & (IC) & 195 & 429 & $\mathrm{U}_{\mathrm{R}}$ \\
\hline $\mathrm{CHO}_{2}^{-}$ & (IC) & 102 & 224 & $\mathrm{U}_{\mathrm{R}}$ \\
\hline TIC & (CA) & 8,740 & 19,200 & - \\
\hline TOC & (CA) & 5,300 & 11,700 & $\mathrm{U}_{\mathrm{R}}, \mathrm{U}_{\mathrm{B}}$ \\
\hline $\mathrm{NH}_{3}$ & (BWXT) & $<99$ & $<220$ & - \\
\hline $\mathrm{CN}^{-}$ & (BWXT) & 13 & 29 & - \\
\hline \multicolumn{3}{|c|}{$\begin{array}{l}\text { QC Flags: - - meets all QC } \\
\mathrm{U}_{\mathrm{B}} \text { - blank exceeds } 5 \% \text { of sample concentration } \\
\mathrm{U}_{\mathrm{O}^{-}} \text {- Outlier omitted in reported average analysis }\end{array}$} & \multicolumn{2}{|c|}{$\begin{array}{l}U_{M} \text { - fails min. reportable quantity } \\
U_{S} \text { - fails \% Recovery of MS }\end{array}$} \\
\hline
\end{tabular}




\subsection{DISCUSSION OF QC FLAGS OF THE SOLIDS FRACTION FROM AY-102/C-106}

As shown in Table 7-2, 4 of the 13 analyses of chemical components were QC flagged for not meeting one or more of the Data Quality Objectives. For each analyte with QC flags, Table 7-4 provides comments/explanations.

Table 7-4. QC Flags for Anion, TIC/TOC, and Ammonia Measurements on the Solid Fraction of AY-102/C-106

\begin{tabular}{|c|c|c|c|c|}
\hline \multicolumn{5}{|c|}{ ty Control Objectives } \\
\hline Analyte & \multirow{2}{*}{$\frac{\text { QC Flag }}{U_{R}}$} & \multicolumn{3}{|c|}{ Comments on QC Flag } \\
\hline (IC) & & \multicolumn{3}{|c|}{$\begin{array}{l}\text { The \% RSD of the replicate analyses was } 28 \% \text { versus the QCO of } \\
15 \% \text {. Since both the LCS and MS recoveries were excellent, the } \\
\text { scatter in data probably reflects problems with sample pretreatment } \\
\text { step required to dissolve the fluoride compounds. }\end{array}$} \\
\hline (IC) & $\mathrm{U}_{\mathrm{R}}$ & \multicolumn{3}{|c|}{$\begin{array}{l}\text { The \% RSD of the replicate analyses was } 39 \% \text { versus the QCO of } \\
15 \% \text {. Since both the LCS and MS recoveries were excellent, the } \\
\text { scatter in data probably reflects problems with sample pretreatment } \\
\text { step required to dissolve the bromide compounds. }\end{array}$} \\
\hline $\mathrm{CHO}_{2}^{-}$(IC) & $\mathrm{U}_{\mathrm{R}}$ & \multicolumn{3}{|c|}{$\begin{array}{l}\text { The } \% \text { RSD of the replicate analyses was } 18 \% \text {, higher than the } \\
\text { QCO of } 15 \% \text {. }\end{array}$} \\
\hline $\begin{array}{l}\text { Total } \\
\text { Organic } \\
\text { Carbon } \\
\text { (CA) }\end{array}$ & $\mathrm{U}_{\mathrm{R}}, \mathrm{U}_{\mathrm{B}}$ & \multicolumn{3}{|c|}{$\begin{array}{l}\text { The \% RSD of the replicate analyses was } 41 \% \text { versus the QCO of } \\
15 \% \text {. Since both the LCS and MS recoveries were excellent, the } \\
\text { scatter in data may reflect problems with the sample work-up in the } \\
\text { shielded cells. The high blank was considered a random } \\
\text { contamination during a TOC analysis and was not observed in other } \\
\text { measurements. Nevertheless, we acknowledge problems with the } \\
\text { blank analysis at the time of analysis. }\end{array}$} \\
\hline & & $\begin{array}{l}\text { centration } \\
\text { ge analysis }\end{array}$ & $\begin{array}{l}U_{R} \text { - fails \% RSD criteria } \\
U_{L} \text { - fails \% Recovery of LCS } \\
\text { N/A - not applicable }\end{array}$ & $\begin{array}{l}U_{M} \text { - fails minimum MRQ criteria } \\
U_{S} \text { - fails } \% \text { Recovery of MS }\end{array}$ \\
\hline
\end{tabular}




\subsection{ELEMENTAL ANALYSES OF THE AY-102/C-106 SOLIDS FRACTION FOLLOWING DIGESTION WITH HOT AQUA REGIA}

The elemental composition of the AY-102/C-106 after the hot aqua regia digestion is compiled in Table 7-5. The Data Quality Objectives (QCO) were met for most analytes. The QC flags (discussed in Table 7-7) were invoked primarily because the analytical precision slightly exceeded the $15 \%$ RSD QCO. Since the concentration of many analytes in the high-caustic supernatant fraction was low, it is not surprising that scatter would increase for measurements of analytes near the detection limit. We were also not able to meet the Minimum Reportable Quantity (MRQ) for four elements (B, Be, Li, V).

Particularly gratifying was the agreement between SRTC and BWXT on the mercury determinations. Although the two labs differed by about $30 \%$ on the mercury determinations, the combined precision was very good (about $15 \%$ RSD). The two laboratories used different technical approaches for the mercury determinations: SRTC analyzed the acid digested sample and BWXT analyzed the undigested sludge.

Table 7-5. Elemental Composition of the As-Received AY-102/C-106 Solids Following Digestion with Hot Aqua Regia

Concentrations are on a Wet Solids (after Centrifugation) Basis

\begin{tabular}{|c|c|c|c|c|c|c|c|c|c|}
\hline Analyte & $\begin{array}{c}1^{\text {st }} \\
\text { Analysis } \\
\text { (mg/kg) }\end{array}$ & $\begin{array}{c}2^{\text {nd }} \\
\text { Analysis } \\
\text { (mg/kg) }\end{array}$ & $\begin{array}{c}3^{\text {rd }} \\
\text { Analysis } \\
\text { (mg/kg) }\end{array}$ & $\begin{array}{c}\text { Average } \\
\text { Analysis } \\
\text { (mg/kg) }\end{array}$ & $\begin{array}{l}\text { RSD } \\
(\%)\end{array}$ & $\begin{array}{c}\text { Blank } \\
\text { Analysis } \\
\text { (mg/kg) }\end{array}$ & $\begin{array}{c}\text { LCS } \\
\text { Recov. } \\
(\%) \\
\end{array}$ & $\begin{array}{c}\text { MS } \\
\text { Recov. } \\
(\%) \\
\end{array}$ & $\begin{array}{l}\text { QC } \\
\text { Flag }\end{array}$ \\
\hline $\mathrm{Ag}$ (ICP-AES) & 344 & 876 & 450 & 567 & $50 \%$ & 5 & $98 \%$ & N/A & $\mathrm{U}_{\mathrm{R}}$ \\
\hline Al (ICP-AES) & 30,100 & 29,800 & 31,900 & 30,600 & $4 \%$ & $<26$ & $99 \%$ & N/A & - \\
\hline As (AAS) & $<20$ & $<20$ & $<20$ & $<20$ & N/A & $<0.03$ & $98 \%$ & $109 \%$ & - \\
\hline B (ICP-AES) & $<74$ & $<137$ & $<137$ & $<137$ & N/A & $<137$ & $101 \%$ & N/A & $\mathrm{U}_{\mathrm{M}}$ \\
\hline $\mathrm{Ba}$ (ICP-AES) & 418 & 417 & 464 & 433 & $6 \%$ & $<62$ & $102 \%$ & $96 \%$ & - \\
\hline $\mathrm{Be}$ (ICP-AES) & $<2$ & $<4$ & $<4$ & $<4$ & N/A & $<4$ & $100 \%$ & $\mathrm{~N} / \mathrm{A}$ & $\mathrm{U}_{\mathrm{M}}$ \\
\hline $\mathrm{Bi} \quad$ (ICP-MS) & 24 & 23 & 27 & 25 & $8 \%$ & $<5$ & $\mathrm{~N} / \mathrm{A}$ & $\mathrm{N} / \mathrm{A}$ & - \\
\hline $\mathrm{Ca}$ (ICP-AES) & 2,280 & 2,300 & 2,530 & 2,370 & $6 \%$ & $<76$ & $100 \%$ & $89 \%$ & - \\
\hline $\mathrm{Cd}$ (ICP-MS) & 75 & 79 & 78 & 77 & $3 \%$ & $<5$ & $100 \%$ & N/A & - \\
\hline $\mathrm{Ce}$ (ICP-MS) & 628 & 642 & 637 & 636 & $1 \%$ & $<89$ & $98 \%$ & N/A & - \\
\hline \multicolumn{6}{|c|}{$\begin{array}{l}\text { QC Flags: - - meets all QC } \\
\mathrm{U}_{\mathrm{B}} \text { - blank exceeds } 5 \% \text { of sample concentration }\end{array}$} & \multicolumn{4}{|c|}{$\begin{array}{l}U_{M} \text { - fails min. reportable quantity } \\
U_{S} \text { - fails \% Recovery of MS }\end{array}$} \\
\hline
\end{tabular}


Table 7-5. Elemental Composition of the As-Received AY-102/C-106 Solids Following Digestion with Hot Aqua Regia - page 2 of 4

Concentrations are on a Wet Solids (after Centrifugation) Basis

\begin{tabular}{|c|c|c|c|c|c|c|c|c|c|}
\hline Analyte & $\begin{array}{c}1^{\text {st }} \\
\text { Analysis } \\
(\mathrm{mg} / \mathrm{kg})\end{array}$ & $\begin{array}{c}2^{\text {nd }} \\
\text { Analysis } \\
(\mathrm{mg} / \mathrm{kg})\end{array}$ & $\begin{array}{c}3^{\text {rd }} \\
\text { Analysis } \\
\text { (mg/kg) }\end{array}$ & $\begin{array}{l}\text { Average } \\
\text { Analysis } \\
(\mathrm{mg} / \mathrm{kg})\end{array}$ & $\begin{array}{l}\text { RSD } \\
(\%)\end{array}$ & $\begin{array}{c}\text { Blank } \\
\text { Analysis } \\
\text { (mg/kg) }\end{array}$ & $\begin{array}{c}\text { LCS } \\
\text { Recov. } \\
(\%) \\
\end{array}$ & $\begin{array}{c}\text { MS } \\
\text { Recov. } \\
(\%)\end{array}$ & $\begin{array}{c}\text { QC } \\
\text { Flag }\end{array}$ \\
\hline Co (ICP-MS) & 23 & 22 & 23 & 23 & $4 \%$ & $<6$ & N/A & N/A & - \\
\hline $\mathrm{Cr}$ (ICP-AES) & 1,120 & 1,160 & 1,250 & 1,180 & $6 \%$ & $<20$ & $103 \%$ & $94 \%$ & - \\
\hline $\begin{array}{l}\text { Cs-133 } \\
\text { (stable Cs) } \\
\text { (ICP-MS) }\end{array}$ & 9 & 9 & 9 & 9 & $2 \%$ & 1 & N/A & $104 \%$ & $\mathrm{U}_{\mathrm{B}}$ \\
\hline Cs-135 & 4 & 4 & 5 & 4 & $4 \%$ & $<1$ & $\mathrm{~N} / \mathrm{A}$ & N/A & - \\
\hline $\begin{array}{l}\text { Cs-137 } \\
\text { (counting-and } \\
\text { using specific } \\
\text { activity of Cs- } \\
137-86.98 \\
\mathrm{mCi} / \mathrm{mg} \text { ) }\end{array}$ & 2.7 & 3.0 & 2.9 & 2.9 & $5 \%$ & $<1$ & N/A & N/A & \\
\hline $\begin{array}{l}\text { Cs (total) } \\
\text { (sum of } \\
\text { measured } \\
\text { isotopes from } \\
\text { ICP-MS and } \\
\text { gamma } \\
\text { counting) }\end{array}$ & 16 & 16 & 17 & 16 & $5 \%$ & 1 & $\mathrm{~N} / \mathrm{A}$ & N/A & - \\
\hline $\mathrm{Cu}$ (ICP-MS) & 170 & 177 & 175 & 174 & $2 \%$ & $<5$ & N/A & $\mathrm{N} / \mathrm{A}$ & - \\
\hline $\mathrm{Fe}$ (ICP-AES) & 65,800 & 65,000 & 72,600 & 67,800 & $6 \%$ & 26 & $101 \%$ & N/A & - \\
\hline $\begin{array}{l}\mathrm{Hg} \\
\text { (from SRTC } \\
\text { on acid } \\
\text { digested } \\
\text { sample) } \\
\quad \text { (AAS) }\end{array}$ & 148 & 150 & 143 & 147 & $2 \%$ & $<0.1$ & $97 \%$ & $100 \%$ & - \\
\hline $\begin{array}{l}\mathrm{Hg} \\
\text { (from BWXT on } \\
\text { as-received wet } \\
\text { solids) (AAS) } \\
\end{array}$ & 110 & 114 & 111 & 112 & $2 \%$ & $<0.04$ & $93 \%$ & $114 \%$ & - \\
\hline $\begin{array}{l}\text { I-127 } \\
\text { (stable I) }\end{array}$ & \multicolumn{9}{|c|}{ No SRTC method for stable iodine at trace concentrations. } \\
\hline $\mathrm{K} \quad$ (AAS) & 420 & 415 & 425 & 420 & $1 \%$ & 1 & $99 \%$ & $98 \%$ & - \\
\hline $\begin{array}{l}\text { QC Flags: - } \\
U_{B}-\text { blank exce } \\
U_{\mathrm{O}^{-}} \text {Outlier om }\end{array}$ & $\begin{array}{l}\text { neets all QC } \\
\text { eds } 5 \% \text { of sa } \\
\text { ted in report }\end{array}$ & $\begin{array}{l}\text { ple concentrat } \\
\text { average anal }\end{array}$ & $\begin{array}{l}\mathrm{U}_{\mathrm{R}}- \\
\mathrm{U}_{\mathrm{L}}- \\
\mathrm{N} / \mathrm{A}\end{array}$ & $\begin{array}{l}\text { ails \% RSD cr } \\
\text { ails \% Recove } \\
\text { not applicable }\end{array}$ & $\begin{array}{l}\text { eria } \\
\text { y of LCS }\end{array}$ & $\begin{array}{l}\mathrm{U}_{\mathrm{M}} \text { - fails } \\
\mathrm{U}_{\mathrm{S}} \text { - fails }\end{array}$ & $\begin{array}{l}\text { hin. report } \\
\text { Recovery }\end{array}$ & $\begin{array}{l}\text { le quantity } \\
\text { f MS }\end{array}$ & \\
\hline
\end{tabular}


Table 7-5. Elemental Composition of the As-Received AY-102/C-106 Solids Following Digestion with Hot Aqua Regia - page 3 of 4

Concentrations are on a Wet Solids (after Centrifugation) Basis

\begin{tabular}{|c|c|c|c|c|c|c|c|c|c|}
\hline Analyte & $\begin{array}{c}1^{\text {st }} \\
\text { Analysis } \\
(\mathrm{mg} / \mathrm{kg})\end{array}$ & $\begin{array}{c}2^{\text {nd }} \\
\text { Analysis } \\
(\mathrm{mg} / \mathrm{kg})\end{array}$ & $\begin{array}{c}3^{\text {rd }} \\
\text { Analysis } \\
(\mathrm{mg} / \mathrm{kg})\end{array}$ & $\begin{array}{l}\text { Average } \\
\text { Analysis } \\
(\mathrm{mg} / \mathrm{kg})\end{array}$ & $\begin{array}{l}\text { RSD } \\
(\%)\end{array}$ & $\begin{array}{c}\text { Blank } \\
\text { Analysis } \\
\text { (mg/kg) }\end{array}$ & $\begin{array}{c}\text { LCS } \\
\text { Recov. } \\
(\%)\end{array}$ & $\begin{array}{c}\text { MS } \\
\text { Recov. } \\
(\%)\end{array}$ & $\begin{array}{l}\text { QC } \\
\text { Flag }\end{array}$ \\
\hline La (ICP-AES) & 426 & 424 & 470 & 440 & $6 \%$ & $<24$ & $99 \%$ & $\mathrm{~N} / \mathrm{A}$ & - \\
\hline $\mathrm{Li}$ (ICP-AES) & 188 & $<210$ & $<210$ & $<210$ & $\mathrm{~N} / \mathrm{A}$ & $<142$ & $103 \%$ & N/A & $\mathrm{U}_{\mathrm{M}}$ \\
\hline $\mathrm{Mg}$ (ICP-AES) & 604 & 600 & 658 & 621 & $5 \%$ & $<17$ & $103 \%$ & N/A & - \\
\hline Mn(ICP-AES) & 14,200 & 14,400 & 15,800 & 14,800 & $6 \%$ & 4.4 & $102 \%$ & N/A & - \\
\hline Mo (ICP-MS) & $<15$ & $<15$ & $<15$ & $<15$ & $\mathrm{~N} / \mathrm{A}$ & $<1$ & $96 \%$ & $\mathrm{~N} / \mathrm{A}$ & - \\
\hline $\mathrm{Na}$ (ICP-AES) & 59,900 & 55,300 & 60,400 & 58,500 & $5 \%$ & $<73$ & $100 \%$ & N/A & $\mathrm{U}_{\mathrm{R}}$ \\
\hline $\mathrm{Ni}$ (ICP-AES) & 2,140 & 2,110 & 2,270 & 2,170 & $4 \%$ & $<45$ & $101 \%$ & $91 \%$ & - \\
\hline $\mathrm{Nd}$ (ICP-MS) & 880 & 900 & 910 & 900 & $2 \%$ & $<0.5$ & N/A & N/A & - \\
\hline $\mathrm{P} \quad$ (ICP-AES) & 1,080 & 1,260 & 1,590 & 1,310 & $20 \%$ & $<228$ & $103 \%$ & $\mathrm{~N} / \mathrm{A}$ & - \\
\hline $\mathrm{Pb}$ (ICP-MS) & 3,260 & 3,310 & 3,250 & 3,270 & $1 \%$ & $<105$ & $100 \%$ & $\mathrm{~N} / \mathrm{A}$ & - \\
\hline $\mathrm{Pd}$ (ICP-MS) & $<50$ & $<50$ & $<50$ & $<50$ & $\mathrm{~N} / \mathrm{A}$ & $<5$ & $\mathrm{~N} / \mathrm{A}$ & $\mathrm{N} / \mathrm{A}$ & - \\
\hline $\operatorname{Pr} \quad$ (ICP-MS) & 249 & 253 & 255 & 252 & $1 \%$ & $<0.1$ & N/A & $\mathrm{N} / \mathrm{A}$ & - \\
\hline $\mathrm{Pt} \quad$ (ICP-MS) & $<3$ & $<3$ & $<3$ & $<3$ & $\mathrm{~N} / \mathrm{A}$ & $<0.5$ & $\mathrm{~N} / \mathrm{A}$ & $\mathrm{N} / \mathrm{A}$ & - \\
\hline $\begin{array}{l}\mathrm{Pu} \text { (sum of } \\
\text { isotopes) } \\
\text { (ICP-MS and } \\
\text { counting) }\end{array}$ & 14 & 22 & 17 & 18 & $25 \%$ & $<0.1$ & N/A & $\mathrm{N} / \mathrm{A}$ & $\mathrm{U}_{\mathrm{R}}$ \\
\hline $\mathrm{Rb}$ (ICP-MS) & $<6$ & $<6$ & $<6$ & $<6$ & $\mathrm{~N} / \mathrm{A}$ & $<0.1$ & N/A & $100 \%$ & - \\
\hline $\mathrm{Rh}$ (ICP-MS) & 21 & 19 & 22 & 21 & $7 \%$ & $<0.2$ & N/A & N/A & - \\
\hline $\mathrm{Ru}$ (ICP-MS) & 233 & 229 & 221 & 228 & $3 \%$ & $<0.4$ & N/A & $\mathrm{N} / \mathrm{A}$ & - \\
\hline $\mathrm{S}$ (ICP-AES) & 674 & 586 & 750 & 670 & $12 \%$ & $<79$ & $100 \%$ & $\mathrm{~N} / \mathrm{A}$ & - \\
\hline $\mathrm{Sb}$ (ICP-MS) & $<6$ & $<6$ & $<6$ & $<6$ & $\mathrm{~N} / \mathrm{A}$ & $<1.0$ & $102 \%$ & N/A & - \\
\hline \multicolumn{6}{|c|}{$\begin{array}{l}\text { QC Flags: - - meets all QC } \\
\mathrm{U}_{\mathrm{B}} \text { - blank exceeds } 5 \% \text { of sample concentration }\end{array}$} & \multicolumn{4}{|c|}{$\begin{array}{l}U_{M} \text { - fails min. reportable quantity } \\
U_{S} \text { - fails \% Recovery of MS }\end{array}$} \\
\hline
\end{tabular}


Table 7-5. Elemental Composition of the As-Received AY-102/C-106 Solids Following Digestion with Hot Aqua Regia - page 4 of 4

Concentrations are on a Wet Solids (after Centrifugation) Basis

\begin{tabular}{|c|c|c|c|c|c|c|c|c|c|}
\hline Analyte & $\begin{array}{c}1^{\text {st }} \\
\text { Analysis } \\
(\mathrm{mg} / \mathrm{kg})\end{array}$ & $\begin{array}{c}2^{\text {nd }} \\
\text { Analysis } \\
(\mathrm{mg} / \mathrm{kg})\end{array}$ & $\begin{array}{c}3^{\text {rd }} \\
\text { Analysis } \\
(\mathrm{mg} / \mathrm{kg})\end{array}$ & $\begin{array}{l}\text { Average } \\
\text { Analysis } \\
(\mathrm{mg} / \mathrm{kg})\end{array}$ & $\begin{array}{c}\text { RSD } \\
(\%)\end{array}$ & $\begin{array}{c}\text { Blank } \\
\text { Analysis } \\
\text { (mg/kg) }\end{array}$ & $\begin{array}{c}\text { LCS } \\
\text { Recov. } \\
(\%)\end{array}$ & $\begin{array}{c}\text { MS } \\
\text { Recov. } \\
(\%)\end{array}$ & $\begin{array}{c}\text { QC } \\
\text { Flag }\end{array}$ \\
\hline $\mathrm{Se} \quad$ (AAS) & $<20$ & $<20$ & $<20$ & $<20$ & N/A & $<0.03$ & $107 \%$ & $69 \%$ & $\mathrm{U}_{\mathrm{S}}$ \\
\hline $\mathrm{Si}$ (ICP-AES) & \multicolumn{9}{|c|}{ Not determined on this digestion. } \\
\hline $\mathrm{Sr}$ (ICP-AES) & 563 & 571 & 626 & 587 & $6 \%$ & $<25$ & $98 \%$ & N/A & - \\
\hline Ta (ICP-MS) & $<6$ & $<6$ & $<6$ & $<6$ & N/A & $<0.5$ & $\mathrm{~N} / \mathrm{A}$ & N/A & - \\
\hline $\begin{array}{l}\text { Tc (liquid } \\
\text { scintillation } \\
\text { counting) }\end{array}$ & 3 & 4 & 2 & 3 & $29 \%$ & $<1$ & $\begin{array}{l}\text { N/A- Tc- } \\
99 \mathrm{~m} \text { added } \\
\text { to trace } \\
\text { recoveries }\end{array}$ & $\begin{array}{l}\text { N/A- Tc- } \\
99 \mathrm{~m} \text { added } \\
\text { to trace } \\
\text { recoveries }\end{array}$ & $\mathrm{U}_{\mathrm{R}}$ \\
\hline Te (ICP-MS) & 30 & 30 & 30 & 30 & $1 \%$ & $<1$ & N/A & N/A & - \\
\hline Th (ICP-MS) & 435 & 459 & 461 & 452 & $3 \%$ & $<2$ & $98 \%$ & $101 \%$ & - \\
\hline $\mathrm{Ti}$ (ICP-AES) & 24 & $<38$ & $<38$ & $<38$ & $\mathrm{~N} / \mathrm{A}$ & $<25$ & $101 \%$ & $\mathrm{~N} / \mathrm{A}$ & $\mathrm{U}_{\mathrm{R}}$ \\
\hline Tl (ICP-MS) & $<5$ & $<5$ & $<5$ & $<5$ & $\mathrm{~N} / \mathrm{A}$ & $<0.5$ & $99 \%$ & $\mathrm{~N} / \mathrm{A}$ & - \\
\hline $\mathrm{U} \quad$ (ICP-MS) & 2,100 & 2,190 & 2,190 & 2,160 & $2 \%$ & 1 & $99 \%$ & $100 \%$ & - \\
\hline $\mathrm{V}$ (ICP-AES) & 8 & $<10$ & $<10$ & $<10$ & N/A & $<10$ & $99 \%$ & N/A & $\mathrm{U}_{\mathrm{R}}, \mathrm{U}_{\mathrm{M}}$ \\
\hline W (ICP-MS) & 164 & 184 & 268 & 205 & $27 \%$ & $<1$ & $\mathrm{~N} / \mathrm{A}$ & $\mathrm{N} / \mathrm{A}$ & $\mathrm{U}_{\mathrm{R}}$ \\
\hline $\mathrm{Y} \quad$ (ICP-MS) & 102 & 103 & 102 & 102 & $1 \%$ & $<4$ & $\mathrm{~N} / \mathrm{A}$ & N/A & - \\
\hline $\mathrm{Zn}$ (ICP-AES) & 112 & 86 & 129 & 109 & $20 \%$ & $<11$ & $101 \%$ & N/A & $\mathrm{U}_{\mathrm{R}}$ \\
\hline $\mathrm{Zr}$ (ICP-AES) & 208 & 850 & 498 & 519 & $62 \%$ & $<75$ & $101 \%$ & N/A & $\mathrm{U}_{\mathrm{R}}$ \\
\hline $\begin{array}{l}\text { QC Flags: - - } \\
U_{B}-\text { blank exc } \\
U_{\mathrm{O}} \text { Outlier om }\end{array}$ & $\begin{array}{l}\text { neets all QC } \\
\text { eds } 5 \% \text { of san } \\
\text { tted in reporte }\end{array}$ & $\begin{array}{l}\text { le concentrat } \\
\text { average anal }\end{array}$ & $\begin{array}{l}\mathrm{U}_{\mathrm{R}}- \\
\mathrm{U}_{\mathrm{L}}- \\
\mathrm{N} / \mathrm{A}\end{array}$ & $\begin{array}{l}\text { tils \% RSD cr } \\
\text { iils \% Recove } \\
\text { not applicable }\end{array}$ & $\begin{array}{l}\text { teria } \\
y \text { of LCS }\end{array}$ & $\begin{array}{l}\mathrm{U}_{\mathrm{M}}-\text { fai } \\
\mathrm{U}_{\mathrm{S}}-\text { fail }\end{array}$ & $\begin{array}{l}\text { in. reporta } \\
\text { Recovery }\end{array}$ & $\begin{array}{l}\text { le quantity } \\
\text { f MS }\end{array}$ & \\
\hline
\end{tabular}

\subsection{ELEMENTAL COMPOSITION OF THE AS-RECEIVED AY-102/C-106 SOLIDS FOLLOWING DIGESTION WITH HOT AQUA REGIA_ON BOTH WET SOLIDS AND DRY SOLIDS BASIS}

As stipulated by the Test Specification, the composition of the solids fraction is to be reported on both a wet basis and a dry basis. To convert the wet basis concentrations to dry basis concentrations, the weight \% dry solids in the wet solids fraction $(45.5 \%)$ was used to obtain the conversion factor of 2.2. To facilitate comparison, both the wet solids basis concentrations and dry solids basis concentrations are included in Table 7-6. 
Table 7-6. Elemental Composition of AY-102/C-106 Solids Fraction Following Digestion with Hot Aqua Regia on Both Wet Solids Basis and Dry Solids Basis

Wet to Dry Conversion Factor is 2.2

\begin{tabular}{|c|c|c|c|}
\hline Analyte & \multirow{2}{*}{$\begin{array}{c}\begin{array}{c}\text { Average Analysis on } \\
\text { Wet Solids Basis (mg/kg) }\end{array} \\
567\end{array}$} & \multirow{2}{*}{$\begin{array}{c}\begin{array}{c}\text { Average Analysis on } \\
\text { Dry Solids Basis (mg/kg) }\end{array} \\
1,250\end{array}$} & \multirow{2}{*}{$\begin{array}{c}\text { QC Flag } \\
U_{R}\end{array}$} \\
\hline $\mathrm{Ag} \quad$ (ICP-AES) & & & \\
\hline Al $\quad$ (ICP-AES) & 30,600 & 67,300 & - \\
\hline (AAS) & $<20$ & $<44$ & - \\
\hline (ICP-AES) & $<137$ & $<300$ & $\mathrm{U}_{\mathrm{M}}$ \\
\hline (ICP-AES) & 953 & 2,100 & - \\
\hline (ICP-AES) & $<4$ & $<9$ & $\mathrm{U}_{\mathrm{M}}$ \\
\hline (ICP-MS) & 25 & 55 & - \\
\hline (ICP-AES) & 2,370 & 5,200 & - \\
\hline (ICP-MS) & 77 & 169 & - \\
\hline (ICP-MS) & 636 & 1399 & - \\
\hline (ICP-MS) & 23 & 51 & - \\
\hline (ICP-AES) & 1,180 & 2,600 & - \\
\hline $\begin{array}{l}\text { Cs-133 } \\
\text { (stable Cs) (ICP-MS) }\end{array}$ & 9 & 20 & $\mathrm{U}_{\mathrm{B}}$ \\
\hline $\begin{array}{l}\text { Cs-135 } \\
\text { (ICP-MS) }\end{array}$ & 4 & 9 & - \\
\hline Cs-137 (counting) & 2.9 & 6.4 & - \\
\hline $\begin{array}{l}\text { Cs (total) (sum of } \\
\text { isotopes from ICP-MS and } \\
\text { counting) }\end{array}$ & 16 & 35 & - \\
\hline (ICP-MS) & 174 & 383 & - \\
\hline $\begin{array}{ll}\mathrm{Fe} & \text { (ICP-AES) }\end{array}$ & 67,800 & 149,000 & - \\
\hline $\begin{array}{l}\mathrm{Hg} \text { (from SRTC on } \\
\text { acid digested sample) }\end{array}$ & 147 & 323 & - \\
\hline $\begin{array}{l}\mathrm{Hg} \text { (from BWXT on } \\
\text { as-received wet } \\
\text { solids-no digestion) } \\
\text { (AAS) }\end{array}$ & 112 & 246 & - \\
\hline $\begin{array}{l}\text { QC Flags: - - meets all } \\
\mathrm{U}_{\mathrm{B}} \text { - blank exceeds } 5 \% \text { of } \\
\mathrm{U}_{\mathrm{O}^{-}} \text {- Outlier omitted in rep }\end{array}$ & $\begin{array}{l}\text { nple concentration } \\
\text { ed average analysis }\end{array}$ & $\begin{array}{l}\text { o RSD criteria } \\
6 \text { Recovery of LCS } \\
\text { pplicable }\end{array}$ & $\begin{array}{l}\text { rtable quantity } \\
\text { ry of MS }\end{array}$ \\
\hline
\end{tabular}


Table 7-6. Elemental Composition of AY-102/C-106 Solids Fraction Following Digestion with Hot Aqua Regia on Both Wet Solids Basis and Dry Solids Basis - page 2 of 3

Wet to Dry Conversion Factor is 2.2

\begin{tabular}{|c|c|c|c|}
\hline Analyte & $\begin{array}{c}\text { Average Analysis on } \\
\text { Wet Solids Basis (mg/kg) }\end{array}$ & $\begin{array}{c}\text { Average Analysis on } \\
\text { Dry Solids Basis (mg/kg) }\end{array}$ & QC Flag \\
\hline $\begin{array}{l}\text { I-127 } \\
\text { (stable I) } \\
\text { (N/A) No reliable method } \\
\text { for ultra trace level of } \\
\text { stable I }\end{array}$ & $\mathrm{N} / \mathrm{A}$ & N/A & N/A \\
\hline (AAS) & 420 & 924 & - \\
\hline (ICP-AES) & 440 & 928 & - \\
\hline (ICP-AES) & $<210$ & $<462$ & $\mathrm{U}_{\mathrm{M}}$ \\
\hline (ICP-AES) & 621 & 1,370 & - \\
\hline (ICP-AES) & 14,800 & 32,600 & - \\
\hline (ICP-MS) & $<15$ & $<33$ & - \\
\hline (ICP-AES) & 58,500 & 128,700 & $\mathrm{U}_{\mathrm{R}}$ \\
\hline (ICP-AES) & 2,170 & 4,770 & - \\
\hline (ICP-MS) & 900 & 1,980 & - \\
\hline (ICP-AES) & 1,310 & 2,900 & - \\
\hline (ICP-MS) & 3,270 & 7,190 & - \\
\hline (ICP-MS) & $<50$ & $<110$ & - \\
\hline (ICP-MS) & 252 & 554 & - \\
\hline (ICP-MS) & $<3$ & $<7$ & - \\
\hline $\begin{array}{l}\mathrm{Pu} \text { (sum of isotopes) } \\
\text { (ICP-MS and counting) }\end{array}$ & 18 & 39 & $\mathrm{U}_{\mathrm{R}}$ \\
\hline (ICP-MS) & $<6$ & $<13$ & - \\
\hline (ICP-MS) & 21 & 46 & - \\
\hline (ICP-MS) & 228 & 500 & - \\
\hline \multicolumn{4}{|c|}{$\begin{array}{l}\text { QC Flags: - - meets all QC } \\
\mathrm{U}_{\mathrm{B}} \text { - blank exceeds } 5 \% \text { of sample concentration } \\
\mathrm{U}_{\mathrm{O}^{-}} \text {Outlier omitted in reported average analysis }\end{array}$} \\
\hline
\end{tabular}


Table 7-6. Elemental Composition of AY-102/C-106 Solids Fraction Following Digestion with Hot Aqua Regia on Both Wet Solids Basis and Dry Solids Basis - page 3 of 3

Wet to Dry Conversion Factor is 2.2

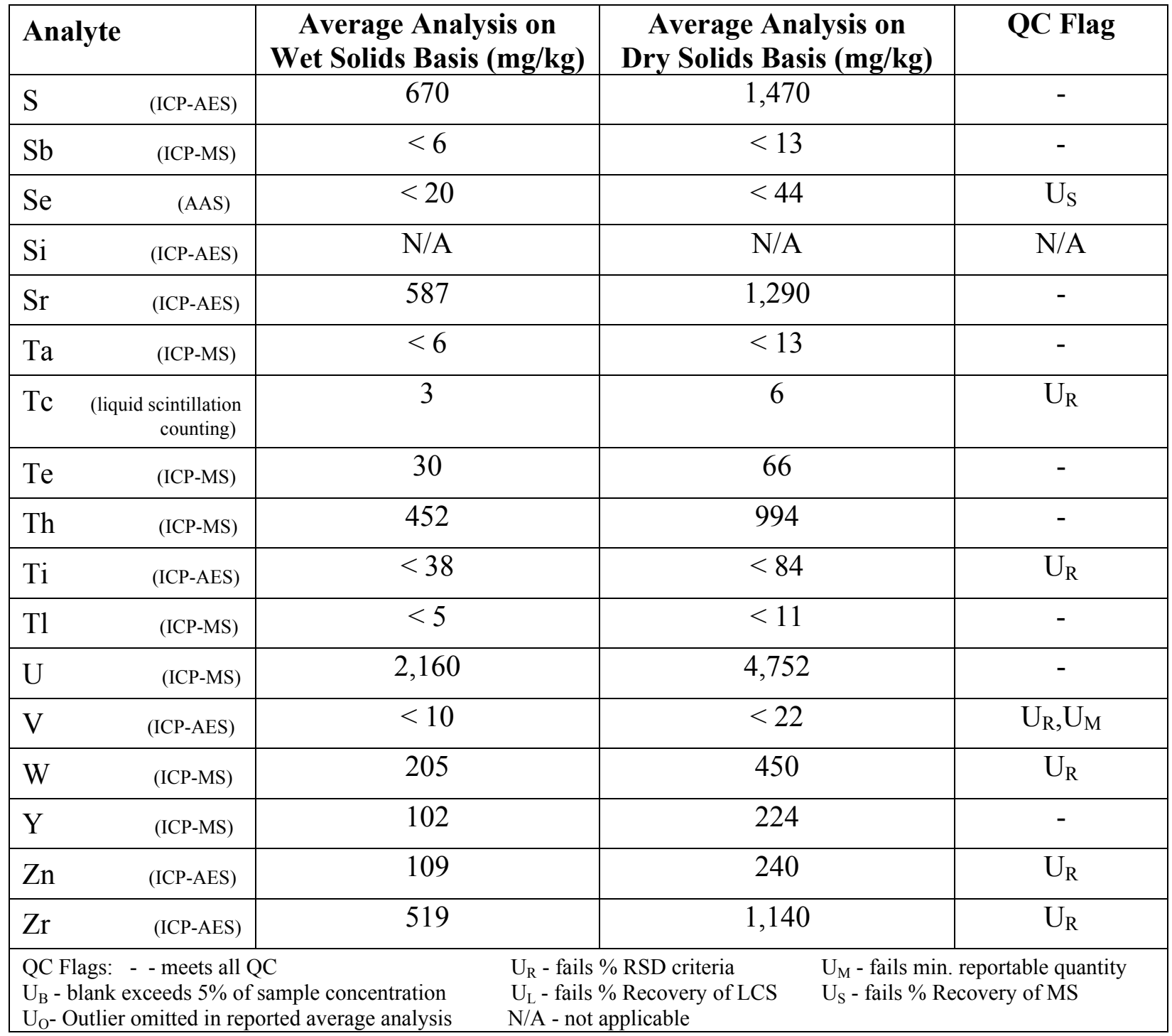




\subsection{QC FLAGS FOR ELEMENTAL ANALYSES OF THE 102/C-106 SOLIDS FRACTION FOLLOWING DIGESTION WITH HOT AQUA REGIA}

As shown in Table 7-5, 14 of the 52 elemental analyses performed on the solids following a hot aqua regia determination were QC flagged for not meeting one or more of the data quality objectives. For each analyte with QC flags, Table 7-7 provides comments/explanations.

Table 7-7. QC Flags for Elemental Analyses on the AY-102/C-106 Solids Fraction Following Digestion with Hot Aqua Regia

\begin{tabular}{|c|c|c|c|}
\hline \multicolumn{4}{|c|}{ QCO $=$ Quality Control Objectives } \\
\hline Analyte & QC Flag & \multicolumn{2}{|c|}{ Comments on QC Flag } \\
\hline $\mathrm{Ag}$ & $\overline{U_{R}}$ & \multicolumn{2}{|c|}{$\begin{array}{l}\text { The \% RSD of Ag determinations was } 50 \% \text { vs. the QCO of }<15 \% \text {. } \\
\text { Better precision was obtained with the } \mathrm{KOH} \text { fusion digestion and } \\
\text { we recommend that the Ag values be obtained from this digestion. }\end{array}$} \\
\hline B & $\mathrm{U}_{\mathrm{M}}$ & \multicolumn{2}{|c|}{$\begin{array}{l}\text { The detection limit of } 137 \mathrm{mg} / \mathrm{kg} \text { exceeded the TMRQ }(3 \mathrm{mg} / \mathrm{kg}) \text {. } \\
\text { The dilutions required to remove the digested sample from the } \\
\text { shielded cells preclude the detection of } \mathrm{B} \text { at this level. }\end{array}$} \\
\hline $\mathrm{Be}$ & $\mathrm{U}_{\mathrm{M}}$ & \multicolumn{2}{|c|}{$\begin{array}{l}\text { The detection limit of } 4 \mathrm{mg} / \mathrm{kg} \text { exceeded the TMRQ }(3 \mathrm{mg} / \mathrm{kg}) \text {. The } \\
\text { dilutions required to remove the digested sample from the shielded } \\
\text { cells preclude the detection of } \mathrm{Be} \text { at this level. }\end{array}$} \\
\hline Cs-133 & $\mathrm{U}_{\mathrm{B}}$ & \multicolumn{2}{|c|}{$\begin{array}{l}\text { The blank analysis was } 1 \mathrm{mg} / \mathrm{kg} \text { versus } 9 \mathrm{mg} / \mathrm{kg} \text { for the average } \\
\text { analysis of the samples. Therefore, the percentage of the blank } \\
\text { exceeded the } 5 \% \text { QCO. }\end{array}$} \\
\hline $\mathrm{Li}$ & $\mathrm{U}_{\mathrm{M}}$ & \multicolumn{2}{|c|}{$\begin{array}{l}\text { The detection limit of } 210 \mathrm{mg} / \mathrm{kg} \text { exceeded TMRQ of } 30 \mathrm{mg} / \mathrm{kg} \text {. } \\
\text { The dilutions required to remove the digested sample from the } \\
\text { shielded cells preclude the detection of } \mathrm{Li} \text { at this level. }\end{array}$} \\
\hline $\mathrm{Na}$ & $\mathrm{U}_{\mathrm{R}}$ & \multicolumn{2}{|c|}{ The $\%$ RSD was $5 \%$ vs. the QCO of $<3.5 \%$. } \\
\hline $\begin{array}{l}\mathrm{Pu}(\text { sum of } \\
\text { isotopes) }\end{array}$ & $\mathrm{U}_{\mathrm{R}}$ & \multicolumn{2}{|c|}{ The $\%$ RSD was $25 \%$ vs. the QCO of $<15 \%$ RSD. } \\
\hline $\mathrm{Se}$ & $\mathrm{U}_{\mathrm{S}}$ & \multicolumn{2}{|c|}{$\begin{array}{l}\text { The \% matrix spike recovery of } 69 \% \text { did not fall within the QCO } \\
85-115 \% \text { matrix spike recovery. }\end{array}$} \\
\hline Tc & $\mathrm{U}_{\mathrm{R}}$ & \multicolumn{2}{|c|}{ The $\%$ RSD was $29 \%$ vs. the QCO \% RSD of $<20 \%$} \\
\hline $\mathrm{Ti}$ & $\mathrm{U}_{\mathrm{R}}$ & \multicolumn{2}{|c|}{$\begin{array}{l}\text { The \% RSD failed because only one of the three determinations } \\
\text { yielded a detectable quantity, whereas the other } 2 \text { measurements } \\
\text { were below detection limit. Therefore, the \% RSD was not } \\
\text { calculable, but clearly could not pass the QCO for \% RSD. }\end{array}$} \\
\hline V & $\mathrm{U}_{\mathrm{R}}, \mathrm{U}_{\mathrm{M}}$ & \multicolumn{2}{|c|}{$\begin{array}{l}\text { The \% RSD failed because only one of the three determinations } \\
\text { yielded a detectable quantity, whereas the other } 2 \text { measurements } \\
\text { were below detection limit. Therefore, the \% RSD was not } \\
\text { calculable, but clearly could not pass the QCO for } \% \text { RSD. The } \\
\text { MRQ of } 6 \mathrm{mg} / \mathrm{kg} \text { was also not met by the measured detection limit } \\
\text { of } 10 \mathrm{mg} / \mathrm{kg} \text {. }\end{array}$} \\
\hline \multicolumn{2}{|c|}{$\begin{array}{l}\text { QC Flags: - - meets all QC } \\
\mathrm{U}_{\mathrm{B}} \text { - blank exceeds } 5 \% \text { of sample concentration } \\
\mathrm{U}_{\mathrm{O}^{-}} \text {Outlier omitted in reported average analysis }\end{array}$} & $\begin{array}{l}\mathrm{U}_{\mathrm{R}} \text { - fails \% RSD criteria } \\
\mathrm{U}_{\mathrm{L}} \text { - fails \% Recovery of LCS } \\
\text { N/A - not applicable }\end{array}$ & $\begin{array}{l}U_{M}-\text { fails minimum MRQ criteria } \\
U_{S} \text { - fails \% Recovery of MS }\end{array}$ \\
\hline
\end{tabular}


Table 7-7. QC Flags for Elemental Analyses on the AY-102/C-106 Solids Fraction Following Digestion with Hot Aqua Regia - page 2 of 2

\begin{tabular}{|c|c|c|c|c|}
\hline \multicolumn{3}{|c|}{ QCO = Quality Control Acceptance Criteria } & \multicolumn{2}{|c|}{ TMRQ = Target Minimum Reportable Quantity } \\
\hline Analyte & QC Flag & \multicolumn{3}{|c|}{ Comments on QC Flag } \\
\hline $\mathrm{W}$ & $\mathrm{U}_{\mathrm{R}}$ & \multicolumn{3}{|c|}{$\begin{array}{l}\text { The } \% \text { RSD of } 27 \% \text { did not meet the QCO of }<15 \% \text {. Better } \\
\text { precision was obtained on the KOH fusion digestion and we } \\
\text { recommend that values from this digestion be used for } \\
\text { characterization. }\end{array}$} \\
\hline $\mathrm{Zn}$ & $\mathrm{U}_{\mathrm{R}}$ & \multicolumn{3}{|c|}{ The $\%$ RSD was $20 \%$ vs. the QCO of $<15 \%$. } \\
\hline $\mathrm{Zr}$ & $\mathrm{U}_{\mathrm{R}}$ & \multicolumn{3}{|c|}{$\begin{array}{l}\text { The \% RSD was } 62 \% \text { vs. the QCO of }<15 \% \text {. The aqua regia } \\
\text { dissolution is not indicated for } \mathrm{Zr} \text { compounds, but was included in } \\
\text { the table for comparison purposes. The } \mathrm{HF}-\mathrm{HNO}_{3}-\mathrm{HCl}-\mathrm{H}_{3} \mathrm{BO}_{3} \\
\text { digestion is used for } \mathrm{Zr} \text { determinations of the solids. }\end{array}$} \\
\hline \multicolumn{3}{|c|}{$\begin{array}{l}\text { QC Flags: - - meets all QC } \\
\mathrm{U}_{\mathrm{B}} \text { - blank exceeds } 5 \% \text { of sample concentration } \\
\mathrm{U}_{\mathrm{O}^{-}} \text {- Outlier omitted in reported average analysis }\end{array}$} & $\begin{array}{l}\mathrm{U}_{\mathrm{R}} \text { - fails \% RSD criteria } \\
\mathrm{U}_{\mathrm{L}} \text { - fails \% Recovery of LCS } \\
\text { N/A - not applicable }\end{array}$ & $\begin{array}{l}U_{M} \text { - fails minimum MRQ criteria } \\
U_{S} \text { - fails \% Recovery of MS }\end{array}$ \\
\hline
\end{tabular}

\subsection{ELEMENTAL ANALYSES OF THE AY-102/C-106 SOLIDS FRACTION FOLLOWING DIGESTION WITH KOH/KNO 3 FUSION}

The $\mathrm{KOH} / \mathrm{KNO}_{3}$ fusion provided clear solutions suitable for analyzing most of the required analytes in AY-102/C-106 solid fraction. Some species have appreciable volatility (As, Se, $\mathrm{Hg}, \mathrm{Cs}$ ) at the $550-600{ }^{\circ} \mathrm{C}$ temperature of the open crucible fusion and are best measured from a sealed, pressurized vessel preparation such as the aqua regia digestion. Other analytes $(\mathrm{K}, \mathrm{Zr}$, $\mathrm{Rb}$ ) are precluded from the fusion preparation by contamination of the analytes from the chemicals and crucibles used in the sample preparation. The radionuclides that are also included in the elemental analysis tables $\left({ }^{99} \mathrm{Tc}, \mathrm{Pu}\right.$ isotopes), were exclusively measured on the aqua regia digestions. $\mathrm{Pd}$ and $\mathrm{Sb}$ were not measured on the fusion digestion because of possible $\mathrm{Zr}$ interferences. The 39 elements for which the $\mathrm{KOH} / \mathrm{KNO}_{3}$ fusion is a suitable digestion method are listed with their respective determinations in Table 7-8. 
Table 7-8. Elemental Composition of the As-received AY-102/C-106 Solids Following Digestion by $\mathrm{KOH} / \mathrm{KNO}_{3}$ Fusion

Concentrations are on a Dry Solids Basis after Drying at $115^{\circ} \mathrm{C}$.

\begin{tabular}{|c|c|c|c|c|c|c|c|c|c|}
\hline Analyte & $\begin{array}{c}1^{\text {st }} \\
\text { Analysis } \\
(\mathrm{mg} / \mathrm{kg})\end{array}$ & $\begin{array}{c}2^{\text {nd }} \\
\text { Analysis } \\
(\mathrm{mg} / \mathrm{kg})\end{array}$ & $\begin{array}{c}3^{\text {rd }} \\
\text { Analysis } \\
\text { (mg/kg) }\end{array}$ & $\begin{array}{l}\text { Average } \\
\text { Analysis } \\
\text { (mg/kg) }\end{array}$ & $\begin{array}{c}\text { RSD } \\
(\%) \\
\end{array}$ & $\begin{array}{c}\text { Blank } \\
\text { Analysis } \\
(\mathrm{mg} / \mathrm{kg})\end{array}$ & $\begin{array}{c}\text { LCS } \\
\text { Recov. } \\
(\%)\end{array}$ & $\begin{array}{c}\text { MS } \\
\text { Recov. } \\
(\%)\end{array}$ & $\begin{array}{c}\text { QC } \\
\text { Flag }\end{array}$ \\
\hline Ag (ICP-MS) & 2,620 & 2,910 & 3,000 & 2,840 & $7 \%$ & 7.5 & $101 \%$ & N/A & - \\
\hline Al (ICP-AES) & 73,000 & 66,800 & 73,300 & 71,000 & $5 \%$ & 62.2 & $100 \%$ & N/A & - \\
\hline As (N/A) & \multicolumn{9}{|c|}{ Not determined on fusions due to As volatility at fusion temperatures. } \\
\hline B (ICP-AES) & 69 & 55 & 33 & 52 & $35 \%$ & $<1$ & $102 \%$ & N/A & $\mathrm{U}_{\mathrm{R}}$ \\
\hline $\mathrm{Ba}$ (ICP-AES) & 1,120 & 1,050 & 1,110 & 1,090 & $3 \%$ & $<12$ & $102 \%$ & $102 \%$ & - \\
\hline Be (ICP-AES) & $<5$ & $<5$ & $<12$ & $<12$ & NA & $<12$ & $104 \%$ & N/A & $\mathrm{U}_{\mathrm{M}}$ \\
\hline $\mathrm{Bi} \quad$ (ICP-MS) & 39 & 40 & 38 & 39 & $3 \%$ & $<5$ & N/A & N/A & - \\
\hline $\mathrm{Ca}$ (ICP-AES) & 5,620 & 5,150 & 5,720 & 5,500 & $6 \%$ & $<15$ & $103 \%$ & $86 \%$ & - \\
\hline $\mathrm{Cd}$ (ICP-MS) & 231 & 214 & 222 & 222 & $4 \%$ & $<3$ & $103 \%$ & $100 \%$ & - \\
\hline Ce (ICP-MS) & 1,430 & 1,430 & 1,490 & 1,450 & $2 \%$ & $<18$ & $99 \%$ & $\mathrm{~N} / \mathrm{A}$ & - \\
\hline Co (ICP-MS) & 37 & 40 & 37 & 38 & $5 \%$ & $<2$ & $\mathrm{~N} / \mathrm{A}$ & $\mathrm{N} / \mathrm{A}$ & - \\
\hline $\mathrm{Cr}$ (ICP-AES) & 2,910 & 2,700 & 2,880 & 2,830 & $4 \%$ & 7 & $102 \%$ & $95 \%$ & - \\
\hline $\begin{array}{r}\text { Cs (total) } \\
(\mathrm{N} / \mathrm{A}) \\
\end{array}$ & \multicolumn{9}{|c|}{ Not determined on fusions due to Cs volatility at fusion temperatures. } \\
\hline $\mathrm{Cu}$ (ICP-MS) & 288 & 330 & 294 & 304 & $7 \%$ & 51 & $\mathrm{~N} / \mathrm{A}$ & $\mathrm{N} / \mathrm{A}$ & - \\
\hline $\mathrm{Fe}$ (ICP-AES) & 163,000 & 153,000 & 165,000 & 160,000 & $4 \%$ & 500 & $103 \%$ & $89 \%$ & - \\
\hline $\mathrm{Hg} \quad(\mathrm{N} / \mathrm{A})$ & \multicolumn{9}{|c|}{ Not determined on fusions due to $\mathrm{Hg}$ volatility at fusion temperatures. } \\
\hline $\mathrm{K} \quad(\mathrm{N} / \mathrm{A})$ & \multicolumn{9}{|c|}{ Not determined on fusions ( $\mathrm{K}$ salts used for flux reagents). } \\
\hline La (ICP-AES) & 1,030 & 950 & 1,080 & 1,020 & $6 \%$ & $<5$ & $100 \%$ & $\mathrm{~N} / \mathrm{A}$ & - \\
\hline Li (ICP-AES) & 501 & 433 & 606 & 513 & $17 \%$ & $<28$ & $102 \%$ & $\mathrm{~N} / \mathrm{A}$ & $\mathrm{U}_{\mathrm{R}}$ \\
\hline $\mathrm{Mg}$ (ICP-AES) & 1,520 & 1,400 & 1,530 & 1,480 & $5 \%$ & 6 & $103 \%$ & N/A & - \\
\hline Mn(ICP-AES) & 35,200 & 32,600 & 35,200 & 34,300 & $4 \%$ & 6 & $102 \%$ & $\mathrm{~N} / \mathrm{A}$ & - \\
\hline Mo (N/A) & \multicolumn{9}{|c|}{ Not determined on fusions because Zr from cruc. interferes with ICP-MS at Mo mass. } \\
\hline $\mathrm{Na}$ (ICP-AES) & 168,000 & 151,000 & 178,000 & 165,700 & $8 \%$ & 342 & $86 \%$ & $83 \%$ & $\begin{array}{c}\mathrm{U}_{\mathrm{R},} \mathrm{U}_{\mathrm{S}}, \\
\mathrm{U}_{\mathrm{L}}\end{array}$ \\
\hline $\begin{array}{l}\text { QC Flags: - - } \\
U_{B}-\text { blank exce } \\
U_{O^{-}} \text {Outlier om }\end{array}$ & $\begin{array}{l}\text { meets all QC } \\
\text { eeds } 5 \% \text { of san } \\
\text { itted in reporte }\end{array}$ & $\begin{array}{l}\text { ple concentrat } \\
\text { average anal }\end{array}$ & $\begin{array}{l}\mathrm{U}_{\mathrm{R}}- \\
\mathrm{U}_{\mathrm{L}}- \\
\mathrm{N} / \mathrm{A}\end{array}$ & $\begin{array}{l}\text { ils \% RSD cr } \\
\text { iils \% Recove } \\
\text { not applicable }\end{array}$ & y of LCS & $\begin{array}{l}U_{M}-f a \\
U_{S}-\text { fai }\end{array}$ & Recovery & $\begin{array}{l}\text { le quantity } \\
\text { f MS }\end{array}$ & \\
\hline
\end{tabular}


Table 7-8. Elemental Composition of the As-received AY-102/C-106 Solids Following Digestion by $\mathrm{KOH} / \mathrm{KNO}_{3}$ Fusion - page 2 of 3

Concentrations are on a Dry Solids Basis after Drying at $115^{\circ} \mathrm{C}$.

\begin{tabular}{|c|c|c|c|c|c|c|c|c|c|}
\hline Analyte & $\begin{array}{c}1^{\text {st }} \\
\text { Analysis } \\
(\mathrm{mg} / \mathrm{kg})\end{array}$ & $\begin{array}{c}2^{\text {nd }} \\
\text { Analysis } \\
(\mathrm{mg} / \mathrm{kg})\end{array}$ & $\begin{array}{c}3^{\text {rd }} \\
\text { Analysis } \\
(\mathrm{mg} / \mathrm{kg})\end{array}$ & $\begin{array}{l}\text { Average } \\
\text { Analysis } \\
(\mathrm{mg} / \mathrm{kg})\end{array}$ & $\begin{array}{l}\text { RSD } \\
(\%)\end{array}$ & $\begin{array}{c}\text { Blank } \\
\text { Analysis } \\
\text { (mg/kg) }\end{array}$ & $\begin{array}{c}\text { LCS } \\
\text { Recov. } \\
(\%)\end{array}$ & $\begin{array}{c}\text { MS } \\
\text { Recov. } \\
(\%) \\
\end{array}$ & $\begin{array}{l}\text { QC } \\
\text { Flag }\end{array}$ \\
\hline $\mathrm{Ni}$ (ICP-AES) & 5,440 & 5,070 & 5,400 & 5,300 & $4 \%$ & 12 & $103 \%$ & $88 \%$ & - \\
\hline $\mathrm{Nd}$ (ICP-MS) & 2,160 & 2,260 & 2,120 & 2,180 & $3 \%$ & $<1$ & $\mathrm{~N} / \mathrm{M}$ & $\mathrm{N} / \mathrm{M}$ & - \\
\hline $\mathrm{P} \quad$ (ICP-AES) & 7,240 & 6,590 & 6,760 & 6,860 & $5 \%$ & $<45$ & $101 \%$ & N/A & - \\
\hline $\mathrm{Pb} \quad$ (ICP-MS) & 7,190 & 7,340 & 6,970 & 7,170 & $3 \%$ & 10 & $100 \%$ & N/A & - \\
\hline $\mathrm{Pd} \quad(\mathrm{N} / \mathrm{A})$ & \multicolumn{9}{|c|}{ Not determined of fusions because $\mathrm{Zr}$ from cruc. interferes with ICP-MS at Pd mass. } \\
\hline $\operatorname{Pr} \quad$ (ICP-MS) & 618 & 633 & 610 & 620 & $1 \%$ & $<2$ & N/A & $\mathrm{N} / \mathrm{A}$ & - \\
\hline Pt (ICP-MS) & $<10$ & $<10$ & $<10$ & $<10$ & N/A & $<1$ & N/A & N/A & $\mathrm{U}_{\mathrm{M}}$ \\
\hline $\mathrm{Pu} \quad(\mathrm{N} / \mathrm{A})$ & \multicolumn{9}{|c|}{ Not determined on fusions; all radiochemical analyses from hot aqua regia digestion. } \\
\hline $\mathrm{Rb}$ (ICP-MS) & \multicolumn{9}{|c|}{ Not determined on fusions because of apparent $\mathrm{Rb}$ contamination in $\mathrm{KOH}$. } \\
\hline $\mathrm{Rh}$ (ICP-MS) & 46 & 49 & 46 & 47 & $4 \%$ & $<1$ & $\mathrm{~N} / \mathrm{M}$ & $\mathrm{N} / \mathrm{A}$ & - \\
\hline $\mathrm{Ru}$ (ICP-MS) & 511 & 491 & 514 & 505 & $2 \%$ & $<1$ & $\mathrm{~N} / \mathrm{M}$ & N/A & - \\
\hline $\mathrm{S} \quad$ (ICP-AES) & 1,940 & 1,720 & 1,840 & 1,830 & $6 \%$ & $<16$ & $92 \%$ & N/A & - \\
\hline $\mathrm{Sb} \quad(\mathrm{N} / \mathrm{A})$ & \multicolumn{9}{|c|}{ Not determined on fusions because of possible $\mathrm{Zr}$ interference. } \\
\hline $\mathrm{Se} \quad(\mathrm{N} / \mathrm{A})$ & \multicolumn{9}{|c|}{ Not determined on fusions because of Se volatility. } \\
\hline Si $\quad$ (ICP-AES) & 46,900 & 43,400 & 45,800 & 45,400 & $4 \%$ & 14 & $103 \%$ & $\mathrm{~N} / \mathrm{A}$ & - \\
\hline $\mathrm{Sr}$ (ICP-AES) & 1,360 & 1,250 & 1,360 & 1,320 & $5 \%$ & $<25$ & $101 \%$ & $\mathrm{~N} / \mathrm{A}$ & - \\
\hline Ta (ICP-MS) & 22 & 22 & 21 & 22 & $3 \%$ & $<1$ & $\mathrm{~N} / \mathrm{M}$ & $\mathrm{N} / \mathrm{A}$ & - \\
\hline $\mathrm{Tc}$ & \multicolumn{9}{|c|}{$\begin{array}{l}\text { Not determined on fusions; all radiochemical analyses from hot aqua regia digestion } \\
\text { except }{ }^{151} \mathrm{Sm} .\end{array}$} \\
\hline Te (ICP-MS) & 71 & 74 & 72 & 72 & $2 \%$ & $<2$ & $\mathrm{~N} / \mathrm{M}$ & N/A & - \\
\hline Th (ICP-MS) & 1,120 & 1,080 & 1,040 & 1,080 & $4 \%$ & $<2$ & $98 \%$ & $101 \%$ & - \\
\hline $\mathrm{Ti}$ (ICP-AES) & 318 & 292 & 334 & 315 & $7 \%$ & $<25$ & $101 \%$ & $\mathrm{~N} / \mathrm{A}$ & - \\
\hline $\mathrm{Tl}$ (ICP-MS) & 4 & 4 & 4 & 4 & $7 \%$ & $<1$ & $99 \%$ & $\mathrm{~N} / \mathrm{A}$ & - \\
\hline $\mathrm{U} \quad$ (ICP-MS) & 5,200 & 5,660 & 5,310 & 5,390 & $4 \%$ & 12 & $102 \%$ & $100 \%$ & - \\
\hline $\begin{array}{l}\text { QC Flags: - - } \\
U_{B}-\text { blank exce } \\
U_{O^{-}} \text {Outlier omi }\end{array}$ & $\begin{array}{l}\text { neets all QC } \\
\text { eds } 5 \% \text { of san } \\
\text { tted in reporte }\end{array}$ & $\begin{array}{l}\text { ple concentrat } \\
\text { average anal }\end{array}$ & $\begin{array}{l}U_{R}- \\
U_{L}- \\
N / A\end{array}$ & $\begin{array}{l}\text { ails \% RSD cr } \\
\text { ails \% Recove } \\
\text { not applicable }\end{array}$ & $\begin{array}{l}\text { ia } \\
\text { of LCS }\end{array}$ & $\begin{array}{l}U_{\mathrm{M}}-\mathrm{fa} \\
\mathrm{U}_{\mathrm{S}}-\mathrm{fa}\end{array}$ & $\begin{array}{l}\text { in. report } \\
\text { Recovery }\end{array}$ & $\begin{array}{l}\text { quantity } \\
\text { MS }\end{array}$ & \\
\hline
\end{tabular}


Table 7-8. Elemental Composition of the As-received AY-102/C-106 Solids Following Digestion by $\mathrm{KOH} / \mathrm{KNO}_{3}$ Fusion - page 3 of 3

Concentrations are on a Dry Solids Basis after Drying at $115^{\circ} \mathrm{C}$.

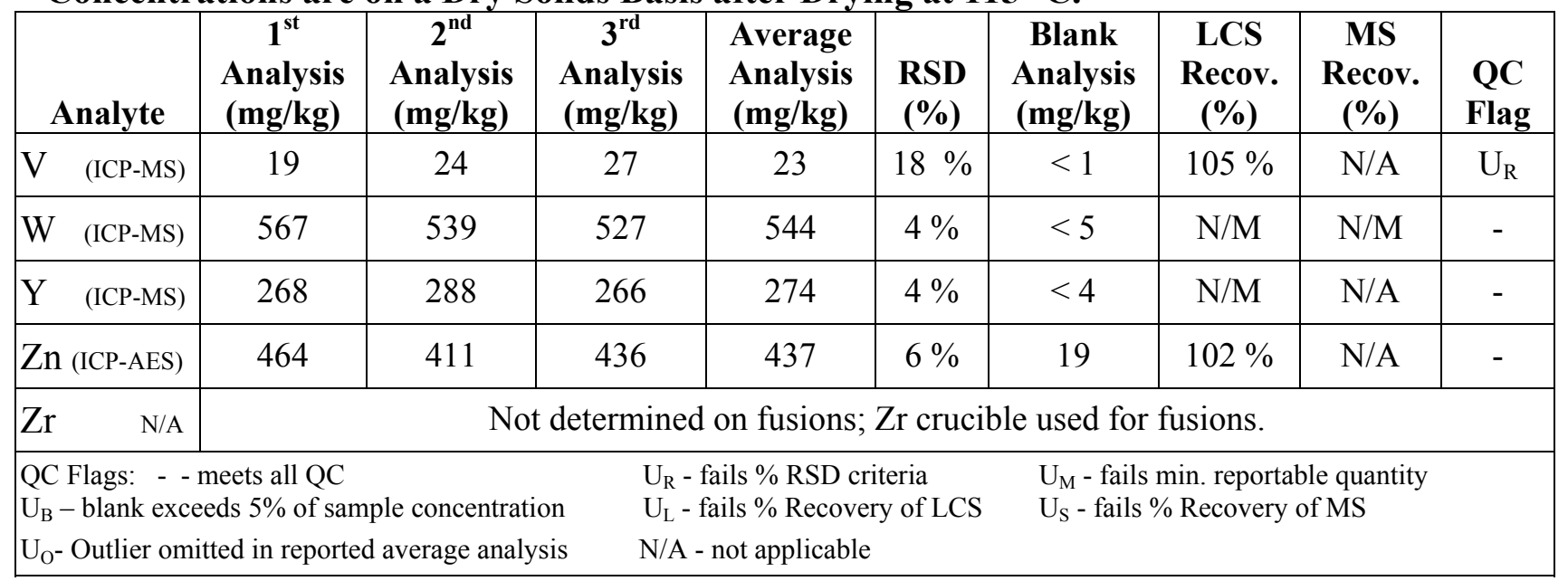

\subsection{ELEMENTAL COMPOSITION OF THE AS-RECEIVED AY-102/C-106 SOLIDS FOLLOWING DIGESTION WITH KOH/KNO 3 FUSION ON BOTH WET SOLIDS AND DRY SOLIDS BASIS}

As stipulated by the Test Specification, the composition of the solids fraction is to be reported on both a wet basis and a dry basis. The $\mathrm{KOH} / \mathrm{KNO}_{3}$ fusions were performed on dry solids and the analytical results were reported on a dry solids basis. To convert the dry basis concentrations to wet basis concentrations, the weight $\%$ dry solids in the wet solids fraction, $45.5 \%$, was used to obtain the conversion factor of 2.2 that was used to divide into the dry solids values. To facilitate comparison, both the wet solids basis concentrations and dry solids basis concentrations are included in Table 7-9. 
Table 7-9. Elemental Composition of AY-102/C-106 Solids Fraction Following Digestion with $\mathrm{KOH} / \mathrm{KNO}_{3}$ on Both Wet Solids Basis and Dry Solids Basis

Wet to Dry Conversion Factor is 2.2

\begin{tabular}{|c|c|c|c|c|}
\hline \multicolumn{2}{|c|}{ Analyte } & \multirow{2}{*}{$\begin{array}{c}\begin{array}{c}\text { Average Analysis on } \\
\text { Wet Solids Basis (mg/kg) }\end{array} \\
1,290\end{array}$} & \multirow{2}{*}{$\begin{array}{c}\begin{array}{c}\text { Average Analysis on } \\
\text { Dry Solids Basis (mg/kg) }\end{array} \\
2,840\end{array}$} & \multirow{2}{*}{$\begin{array}{c}\text { QC Flag } \\
-\end{array}$} \\
\hline $\mathrm{Ag}$ & (ICP-AES) & & & \\
\hline $\mathrm{Al}$ & (ICP-AES) & 32,300 & 71,000 & - \\
\hline As & (AAS) & $\mathrm{N} / \mathrm{A}$ & N/A & $\mathrm{N} / \mathrm{A}$ \\
\hline B & (ICP-AES) & 24 & 52 & $\mathrm{U}_{\mathrm{R}}$ \\
\hline $\mathrm{Ba}$ & (ICP-AES) & 500 & 1,090 & - \\
\hline $\mathrm{Be}$ & (ICP-AES) & $<5$ & $<12$ & $\mathrm{U}_{\mathrm{M}}$ \\
\hline $\mathrm{Bi}$ & (ICP-MS) & 18 & 39 & - \\
\hline $\mathrm{Ca}$ & (ICP-AES) & 2,500 & 5,500 & - \\
\hline $\mathrm{Cd}$ & (ICP-MS) & 100 & 222 & - \\
\hline $\mathrm{Ce}$ & (ICP-MS) & 660 & 1,450 & - \\
\hline $\mathrm{Co}$ & (ICP-MS) & 17 & 38 & - \\
\hline $\mathrm{Cr}$ & (ICP-AES) & 1,290 & 2,830 & - \\
\hline Cs (total) & (ICP-MS) & $\mathrm{N} / \mathrm{A}$ & N/A & $\mathrm{N} / \mathrm{A}$ \\
\hline $\mathrm{Cu}$ & (ICP-MS) & 140 & 308 & - \\
\hline $\mathrm{Fe}$ & (ICP-AES) & 72,700 & 160,000 & - \\
\hline $\mathrm{Hg}$ & $(\mathrm{N} / \mathrm{A})$ & $\mathrm{N} / \mathrm{A}$ & $\mathrm{N} / \mathrm{A}$ & $\mathrm{N} / \mathrm{A}$ \\
\hline $\mathrm{K}$ & (N/A) & $\mathrm{N} / \mathrm{A}$ & N/A & $\mathrm{N} / \mathrm{A}$ \\
\hline $\mathrm{La}$ & (ICP-AES) & 460 & 1,020 & - \\
\hline $\mathrm{Li}$ & (ICP-AES) & 233 & 513 & $\mathrm{U}_{\mathrm{R}}$ \\
\hline $\mathrm{Mg}$ & (ICP-AES) & 670 & 1,470 & - \\
\hline $\mathrm{Mn}$ & (ICP-AES) & 15,600 & 34,300 & - \\
\hline $\begin{array}{l}\text { QC Flags: - } \\
\mathrm{U}_{\mathrm{B}} \text { - blank ex } \\
\mathrm{U}_{\mathrm{O}^{-}} \text {- Outlier o }\end{array}$ & $\begin{array}{l}\text { - meets all } \\
\text { ceeds } 5 \% \text { of } \\
\text { mitted in rep }\end{array}$ & $\begin{array}{l}\text { mple concentration } \\
\text { ted average analysis }\end{array}$ & $\begin{array}{l}\text { o RSD criteria } \\
\text { o Recovery of LCS } \\
\text { pplicable }\end{array}$ & $\begin{array}{l}\text { ortable quantity } \\
\text { ery of MS }\end{array}$ \\
\hline
\end{tabular}


Table 7-9. Elemental Composition of AY-102/C-106 Solids Fraction Following Digestion with $\mathrm{KOH} / \mathrm{KNO}_{3}$ on Both Wet Solids Basis and Dry Solids Basis - page 2 of 3

Wet to Dry Conversion Factor is 2.2

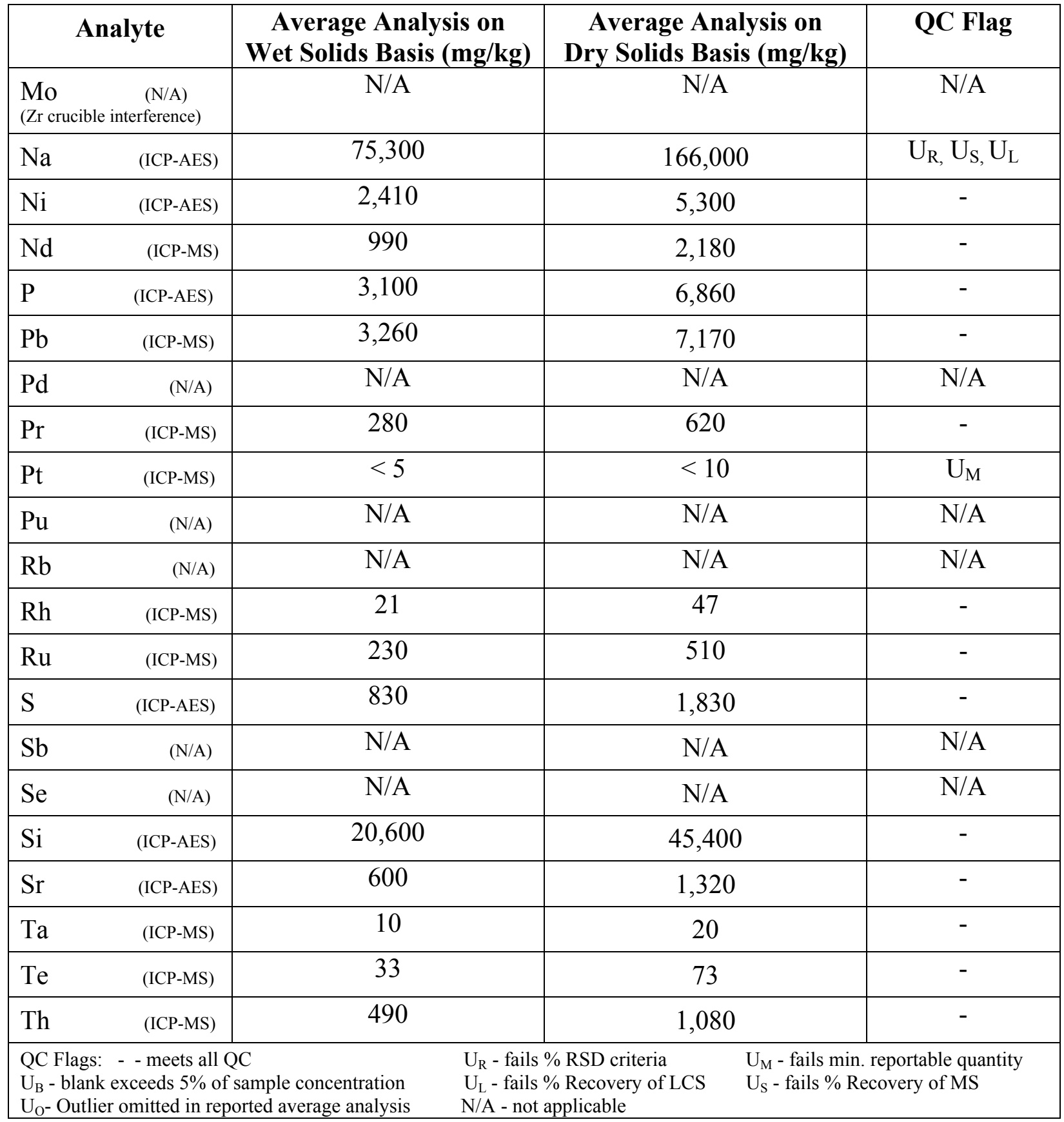


Table 7-9. Elemental Composition of AY-102/C-106 Solids Fraction Following Digestion with $\mathrm{KOH} / \mathrm{KNO}_{3}$ on Both Wet Solids Basis and Dry Solids Basis - page 3 of 3

Wet to Dry Conversion Factor is 2.2

\begin{tabular}{|c|c|c|c|c|c|c|}
\hline \multicolumn{2}{|c|}{ Analyte } & \multicolumn{2}{|c|}{$\begin{array}{c}\text { Average Analysis on } \\
\text { Wet Solids Basis (mg/kg) }\end{array}$} & \multicolumn{2}{|c|}{$\begin{array}{c}\text { Average Analysis on } \\
\text { Dry Solids Basis (mg/kg) }\end{array}$} & \multirow{2}{*}{$\begin{array}{c}\text { QC Flag } \\
-\end{array}$} \\
\hline $\mathrm{Ti}$ & (ICP-AES) & 143 & & 315 & & \\
\hline $\mathrm{Tl}$ & (ICP-MS) & 2 & & 4 & & - \\
\hline $\mathrm{U}$ & (ICP-MS) & 2,450 & & 5,390 & & - \\
\hline $\mathrm{V}$ & (ICP-MS) & 10 & & 23 & & $\mathrm{U}_{\mathrm{R}}$ \\
\hline W & (ICP-MS) & 245 & & 544 & & - \\
\hline Y & (ICP-MS) & 124 & & 274 & & - \\
\hline $\mathrm{Zn}$ & (ICP-AES) & 199 & & 437 & & - \\
\hline & $(\mathrm{N} / \mathrm{A})$ & $\mathrm{N} / \mathrm{A}$ & & N/A & & $\mathrm{N} / \mathrm{A}$ \\
\hline \multicolumn{3}{|c|}{$\begin{array}{l}\text { QC Flags: - - meets all QC } \\
\mathrm{U}_{\mathrm{B}} \text { - blank exceeds } 5 \% \text { of sample concentration } \\
\mathrm{U}_{\mathrm{O}^{-}} \text {- Outlier omitted in reported average analysis }\end{array}$} & $\begin{array}{l}U_{R}-\text { fails } \\
U_{L}-\text { fails } \\
\text { N/A - no }\end{array}$ & $\begin{array}{l}\text { RSD criteria } \\
\text { Recovery of LCS } \\
\text { oplicable }\end{array}$ & $\begin{array}{l}U_{M} \text { - fails mir } \\
U_{S} \text { - fails } \% R\end{array}$ & $\begin{array}{l}\text { rtable quantity } \\
\text { ry of MS }\end{array}$ \\
\hline
\end{tabular}




\subsection{DISCUSSION OF QC FLAGS FOR TABLE 7-8}

Six QC flags were necessary for the 39 determinations performed on the $\mathrm{KOH} / \mathrm{KNO}_{3}$ fusion digestion. For each analyte with QC flags, Table 7-10 provides the following comments/explanations.

Table 7-10. QC Flags for Elemental Analyses on the AY-102/C-106 Solids Fraction Following Digestion with $\mathrm{KOH} / \mathrm{KNO}_{3}$

\begin{tabular}{|c|c|c|c|c|}
\hline \multicolumn{5}{|c|}{ Control Ob } \\
\hline Analyte & QC Flag & \multicolumn{3}{|c|}{ Comments on QC Flag } \\
\hline (ICP-AES) & $\mathrm{U}_{\mathrm{R}}$ & \multicolumn{3}{|c|}{$\begin{array}{l}\text { The } \% \text { RSD of } 35 \% \text { did not meet the QCO } \% \text { RSD of }<15 \% \text {. The } \\
\text { B was measured at near the detection limit providing a possible } \\
\text { explanation for not meeting the }<15 \% \text { RSD QCO. }\end{array}$} \\
\hline & $\mathrm{U}_{\mathrm{M}}$ & \multicolumn{3}{|c|}{$\begin{array}{l}\text { The detection limit of } 5 \mathrm{mg} / \mathrm{kg} \text { on a wet solids basis slightly } \\
\text { exceeded the TMRQ of } 3 \mathrm{mg} / \mathrm{kg} \text {. }\end{array}$} \\
\hline (ICP-AES) & $\mathrm{U}_{\mathrm{R}}$ & \multicolumn{3}{|c|}{$\begin{array}{l}\text { The \% RSD of } 17 \% \text { was just slightly outside the QCO \% RSD of }< \\
15 \% \text {. }\end{array}$} \\
\hline (ICP-AES) & $\begin{array}{l}\mathrm{U}_{\mathrm{R},} \mathrm{U}_{\mathrm{S}} \\
\mathrm{U}_{\mathrm{L}}\end{array}$ & \multicolumn{3}{|c|}{$\begin{array}{l}\text { The } \% \text { RSD of } 8 \% \text { exceeded the QCO \% RSD of } 3.5 \% \text {. However, } \\
8 \% \text { RSD for Na determinations of solid samples dissolved } \\
\text { remotely and analyzed by ICP-AES is typical and falls within } \\
\text { normal SRTC QC limits for Na. The laboratory control standard } \\
\text { recovery was } 86 \% \text { vs. the QCO of } 90-100 \% \text {. The matrix spike } \\
\text { recovery was } 83 \% \text { vs. the QCO of } 90-100 \% \text {. However, the } \\
\text { principal accuracy indicator for Na was the confirmatory analysis of } \\
\text { the } \mathrm{HF}-\mathrm{HNO} \mathrm{O}_{3}-\mathrm{HCl}-\mathrm{H}_{3} \mathrm{BO}_{3} \text { digestion (see Table } 7-11 \text { ). The average } \\
\mathrm{Na} \text { determinations from these two } \mathrm{separate} \text { digestion procedures } \\
\text { (KOH fusion and } \mathrm{HF}-\mathrm{HNO}_{3}-\mathrm{HCl}-\mathrm{H}_{3} \mathrm{BO}_{3} \text { ) were within } 2 \% \text { relative. }\end{array}$} \\
\hline (ICP-MS & $\mathrm{U}_{\mathrm{M}}$ & \multicolumn{3}{|c|}{$\begin{array}{l}\text { The detection limit of } 10 \mathrm{mg} / \mathrm{kg} \text { (dry basis) exceeded the MRQ of } \\
3 \mathrm{mg} / \mathrm{kg} \text {. }\end{array}$} \\
\hline (ICP-MS) & $\mathrm{U}_{\mathrm{R}}$ & \multicolumn{3}{|c|}{ The $\%$ RSD was $18 \%$, higher than the QCO $\%$ RSD of $<15 \%$. } \\
\hline $\begin{array}{l}\text { blank ex } \\
\text { Outlier o }\end{array}$ & & $\begin{array}{l}\text { ncentration } \\
\text { age analysis }\end{array}$ & $\begin{array}{l}U_{R} \text { - fails \% RSD criteria } \\
U_{L} \text { - fails \% Recovery of LCS } \\
\text { N/A - not applicable }\end{array}$ & $\begin{array}{l}\mathrm{U}_{\mathrm{M}} \text { - fails minimum MRQ criteria } \\
\mathrm{U}_{\mathrm{S}} \text { - fails \% Recovery of MS }\end{array}$ \\
\hline
\end{tabular}




\subsection{ELEMENTAL ANALYSES ON THE AY-102/C-106 SOLIDS FRACTION FOLLOWING DIGESTION WITH HOT HF-HNO $-\mathrm{HCL}_{3}-\mathrm{H}_{3} \mathrm{BO}_{3}$}

This digestion was not part of our original plan. However, Hanford technical personnel Bill Winters and Cary Seidell suggested to us that HF is effective for digesting many Hanford sludges with high $\mathrm{Zr}$ content. We also needed a third acid digestion to help settle the discrepancy in $\mathrm{Na}$ values between the hot aqua digestion and the $\mathrm{KOH} / \mathrm{KNO}_{3}$ fusion digestion. The same level of QA/QC was used with this digestion as with all the other analyses, but only those elements that are normally obtained in routine ICP-AES measurements at SRTC were determined. This explains why the list of measured elements is considerably shorter for this digestion than for the hot aqua regia and $\mathrm{KOH} / \mathrm{KNO}_{3}$ digestions.

The average $\mathrm{Na}$ concentration on a wet solids basis from this digestion was $73,800 \mathrm{mg} / \mathrm{kg}$ vs. $75,300 \mathrm{mg} / \mathrm{kg}$ from the $\mathrm{KOH} / \mathrm{KNO} 3$ fusion. This agreement of $\mathrm{Na}$ values of two digestion methods within $2 \%$ relative led us to choose to report $\mathrm{Na}$ values on the solid fraction from the $\mathrm{KOH} / \mathrm{KNO} 3$ fusion method. The $\mathrm{Zr}$ determinations from the $\mathrm{Hot} \mathrm{HF}-\mathrm{HNO}_{3}-\mathrm{HCl}-\mathrm{H}_{3} \mathrm{BO}_{3}$ digestion showed acceptable $9 \%$ RSD precision and good recovery of the laboratory control standard. Therefore, we reported the $\mathrm{Zr}$ values based on this digestion. We also chose to report the $\mathrm{Li}$ values based on the $\mathrm{Hot} \mathrm{HF}-\mathrm{HNO}_{3}-\mathrm{HCl}-\mathrm{H}_{3} \mathrm{BO}_{3}$ since this digestion is much less likely than the $\mathrm{KOH} / \mathrm{KNO}_{3}$ fusion to be contaminated with $\mathrm{Li}$. 
Table 7-11. Elemental Composition of the As-Received AY-102/C-106 Solids Following Digestion with $\mathrm{Hot} \mathrm{HF}-\mathrm{HNO}_{3}-\mathrm{HCl}-\mathrm{H}_{3} \mathrm{BO}_{3}$

All Determinations were made using ICP-AES Methods

\begin{tabular}{|c|c|c|c|c|c|c|c|c|c|}
\hline Analyte & $\begin{array}{c}1^{\text {st }} \\
\text { Analysis } \\
(\mathrm{mg} / \mathrm{kg})\end{array}$ & $\begin{array}{c}2^{\text {nd }} \\
\text { Analysis } \\
(\mathrm{mg} / \mathrm{kg})\end{array}$ & $\begin{array}{c}3^{\text {rd }} \\
\text { Analysis } \\
(\mathrm{mg} / \mathrm{kg})\end{array}$ & $\begin{array}{l}\text { Average } \\
\text { Analysis } \\
(\mathrm{mg} / \mathrm{kg})\end{array}$ & $\begin{array}{l}\text { RSD } \\
(\%)\end{array}$ & $\begin{array}{c}\text { Blank } \\
\text { Analysis } \\
\text { (mg/kg) }\end{array}$ & $\begin{array}{c}\text { LCS } \\
\text { Recov. } \\
(\%)\end{array}$ & $\begin{array}{c}\text { MS } \\
\text { Recov. } \\
(\%)\end{array}$ & $\begin{array}{c}\text { QC } \\
\text { Flag }\end{array}$ \\
\hline $\mathrm{Ag}$ & 162 & 204 & 256 & 207 & $23 \%$ & 100 & $100 \%$ & $\mathrm{~N} / \mathrm{A}$ & $\mathrm{U}_{\mathrm{B}}, \mathrm{U}_{\mathrm{R}}$ \\
\hline $\mathrm{Al}$ & 35,100 & 35,600 & 44,700 & 38,500 & $14 \%$ & $<51$ & $100 \%$ & N/A & - \\
\hline $\mathrm{Ba}$ & 432 & 428 & 487 & 449 & $7 \%$ & $<17$ & $100 \%$ & $98 \%$ & - \\
\hline $\mathrm{Be}$ & $<1$ & $<1$ & $<1$ & $<1$ & N/A & $<1$ & $99 \%$ & N/A & - \\
\hline $\mathrm{Ca}$ & 2,590 & 2,550 & 2,960 & 2,700 & $8 \%$ & $<21$ & $101 \%$ & N/A & - \\
\hline $\mathrm{Cd}$ & 86 & 87 & 97 & 90 & $7 \%$ & $<4$ & $99 \%$ & $95 \%$ & - \\
\hline $\mathrm{Cr}$ & 1,200 & 1,310 & 1,480 & 1,330 & $11 \%$ & 42 & $99 \%$ & $96 \%$ & - \\
\hline $\mathrm{Fe}$ & 74,600 & 73,800 & 83,200 & 77,200 & $7 \%$ & 188 & $100 \%$ & $97 \%$ & - \\
\hline $\mathrm{Li}$ & 208 & 206 & 230 & 215 & $6 \%$ & $<39$ & $99 \%$ & $\mathrm{~N} / \mathrm{A}$ & - \\
\hline $\mathrm{Mg}$ & 655 & 661 & 793 & 703 & $11 \%$ & $<5$ & $101 \%$ & $\mathrm{~N} / \mathrm{A}$ & - \\
\hline Mn & 15,800 & 15,500 & 17,500 & 16,300 & $7 \%$ & 5 & $100 \%$ & N/A & - \\
\hline $\mathrm{Na}$ & 68,000 & 69,100 & 84,200 & 73,800 & $12 \%$ & 2,780 & $99 \%$ & $106 \%$ & $\mathrm{U}_{\mathrm{R}}$ \\
\hline $\mathrm{Ni}$ & 2,400 & 2,520 & 2,740 & 2,550 & $7 \%$ & $<12$ & $101 \%$ & $96 \%$ & - \\
\hline $\mathrm{P}$ & 2,670 & 2,530 & 2,490 & 2,560 & $7 \%$ & $<62$ & $100 \%$ & N/A & - \\
\hline $\mathrm{Pb}$ & 3,350 & 3,310 & 3,670 & 3,440 & $7 \%$ & $<29$ & $99 \%$ & N/A & - \\
\hline S & 900 & 825 & 1,120 & 950 & $16 \%$ & $<124$ & $97 \%$ & N/A & $\mathrm{U}_{\mathrm{R}}$ \\
\hline V & 24 & 24 & 29 & 26 & $11 \%$ & 11 & 101 & N/A & $\mathrm{U}_{\mathrm{B}}$ \\
\hline $\mathrm{Zn}$ & $<3$ & 8 & 19 & $\sim 10$ & $\mathrm{~N} / \mathrm{A}$ & $<3$ & $98 \%$ & N/A & $\mathrm{U}_{\mathrm{R}}, \mathrm{U}_{\mathrm{M}}$ \\
\hline $\mathrm{Zr}$ & 2,450 & 2,410 & 2,840 & 2,570 & $9 \%$ & $<21$ & $98 \%$ & N/A & - \\
\hline \multicolumn{6}{|c|}{$\begin{array}{l}\text { QC Flags: - - meets all QC } \\
\mathrm{U}_{\mathrm{B}} \text { - blank exceeds } 5 \% \text { of sample concentration } \\
\mathrm{U}_{\mathrm{O}} \text { - Outlier omitted in reported average analysis }\end{array}$} & \multicolumn{4}{|c|}{$\begin{array}{l}U_{M} \text { - fails min. reportable quantity } \\
U_{S} \text { - fails \% Recovery of MS }\end{array}$} \\
\hline
\end{tabular}




\subsection{ELEMENTAL COMPOSITION OF THE AS-RECEIVED AY-102/C-106 SOLIDS FOLLOWING DIGESTION WITH HOT HF-HNO ${ }_{3}-\mathrm{HCL}_{-} \mathrm{H}_{3} \mathrm{BO}_{3} \mathrm{ON}$ BOTH WET SOLIDS AND DRY SOLIDS BASIS}

As stipulated by the Test Specification, the composition of the solids fraction is to be reported on both a wet basis and a dry basis. The Hot $\mathrm{HF}-\mathrm{HNO}_{3}-\mathrm{HCl}-\mathrm{H}_{3} \mathrm{BO}_{3}$ digestions were performed on wet solids and the analytical results were reported on a wet solids basis. To convert the wet basis concentrations to dry basis concentrations, the weight $\%$ dry solids in the wet solids fraction, $45.5 \%$, was used to obtain the conversion factor of 2.2 that was used to multiple values. To facilitate comparison, both the wet solids basis concentrations and dry solids basis concentrations are included in Table 7-12.

Table 7-12. Elemental Composition of AY-102/C-106 Solids Fraction Following Digestion with $\mathrm{Hot} \mathrm{HF}-\mathrm{HNO} \mathrm{O}_{3}-\mathrm{HCl}-\mathrm{H}_{3} \mathrm{BO}_{3}$ on Both Wet Solids Basis and Dry Solids Basis

Wet to Dry Conversion Factor is 2.2

\begin{tabular}{|c|c|c|c|}
\hline Analyte & $\begin{array}{c}\text { Average Analysis on } \\
\text { Wet Solids Basis (mg/kg) }\end{array}$ & $\begin{array}{c}\text { Average Analysis on } \\
\text { Dry Solids Basis (mg/kg) }\end{array}$ & QC Flag \\
\hline $\mathrm{Ag}$ & 207 & 455 & $\mathrm{U}_{\mathrm{B}}, \mathrm{U}_{\mathrm{R}}$ \\
\hline $\mathrm{Al}$ & 38,500 & 84,600 & - \\
\hline $\mathrm{Ba}$ & 449 & 988 & - \\
\hline $\mathrm{Be}$ & $<1$ & $<2$ & - \\
\hline $\mathrm{Ca}$ & 2,700 & 5,940 & - \\
\hline $\mathrm{Cd}$ & 90 & 198 & - \\
\hline $\mathrm{Cr}$ & 1,330 & 2,930 & - \\
\hline $\mathrm{Fe}$ & 77,200 & 170,000 & - \\
\hline $\mathrm{Li}$ & 215 & 473 & - \\
\hline $\mathrm{Mg}$ & 703 & 1,550 & - \\
\hline $\mathrm{Mn}$ & 16,300 & 35,800 & - \\
\hline $\mathrm{Na}$ & 73,800 & 162,000 & $\mathrm{U}_{\mathrm{R}}$ \\
\hline $\mathrm{Ni}$ & 2,550 & 5,610 & - \\
\hline $\mathrm{P}$ & 2,560 & 5,630 & - \\
\hline $\mathrm{Pb}$ & 3,440 & 7,570 & - \\
\hline S & 950 & 2,090 & $\mathrm{U}_{\mathrm{R}}$ \\
\hline V & 26 & 57 & $\mathrm{U}_{\mathrm{B}}$ \\
\hline $\mathrm{Zn}$ & $\sim 10$ & $\sim 22$ & $\mathrm{U}_{\mathrm{R},}, \mathrm{U}_{\mathrm{M}}$ \\
\hline $\mathrm{Zr}$ & 2,570 & 5,650 & - \\
\hline \multicolumn{2}{|c|}{$\begin{array}{l}\text { QC Flags: - - meets all QC } \\
\mathrm{U}_{\mathrm{B}} \text { - blank exceeds } 5 \% \text { of sample concentration } \\
\mathrm{U}_{\mathrm{O}^{-}} \text {Outlier omitted in reported average analysis }\end{array}$} & $\begin{array}{l}\text { RSD criteria } \\
\text { Recovery of LCS } \\
\text { pplicable }\end{array}$ & $\begin{array}{l}U_{M} \text { - fails min. reportable quantity } \\
U_{S} \text { - fails \% Recovery of MS }\end{array}$ \\
\hline
\end{tabular}




\subsection{DISCUSSION OF QC FLAGS FOR TABLE 7-11}

Five of the 19 determinations made with the Hot $\mathrm{HF}-\mathrm{HNO}_{3}-\mathrm{HCl}-\mathrm{H}_{3} \mathrm{BO}_{3}$ digestion required QC flags. The Hot $\mathrm{HF}-\mathrm{HNO}_{3}-\mathrm{HCl}-\mathrm{H}_{3} \mathrm{BO}_{3}$ method is not the preferred digestion method for any of these five elements. Nevertheless, for each analyte with QC flags, Table 7-13 provides comments/explanations.

Table 7-13. QC flags for Elemental Analyses on the AY-102/C-106 Solids Fraction Following Digestion with $\mathrm{Hot} \mathrm{HF}-\mathrm{HNO}_{3}-\mathrm{HCl}-\mathrm{H}_{3} \mathrm{BO}_{3}$

QCO = Quality Control Objective $\quad$ MRQ = Minimum Reportable Quantity

\begin{tabular}{|c|c|c|c|c|}
\hline Analyte & QC Flag & \multicolumn{3}{|c|}{ Comments on QC Flag } \\
\hline (ICP-AES) & $\mathrm{U}_{\mathrm{B}}, \mathrm{U}_{\mathrm{R}}$ & \multicolumn{3}{|c|}{$\begin{array}{l}\text { This method, including both the digestion and the use of ICP-AES } \\
\text { rather than ICP-MS to measure low concentrations of Ag, is not } \\
\text { recommended. Ag was reported with the normal suite of elements } \\
\text { routinely analyzed by the ICP-AES lab at SRTC and is included } \\
\text { here only for comparison. }\end{array}$} \\
\hline (ICP-AES) & $\mathrm{U}_{\mathrm{R}}$ & \multicolumn{3}{|c|}{$\begin{array}{l}\text { The } \% \text { RSD of } 12 \% \text { exceeded the QCO of }<3.5 \% \text { RSD. The } \\
\text { principal use for the Na determination was the confirmatory } \\
\text { analysis of the } \mathrm{KOH} \text { fusion digestion. The average } \mathrm{Na} \\
\text { determinations from these two separate digestion procedures }(\mathrm{KOH} \\
\left.\text { fusion and } \mathrm{HF}-\mathrm{HNO}_{3}-\mathrm{HCl}-\mathrm{H}_{3} \mathrm{BO}_{3}\right) \text { were within } 2 \% \text { relative. }\end{array}$} \\
\hline S & $\mathrm{U}_{\mathrm{R}}$ & \multicolumn{3}{|c|}{ The $\%$ RSD of $16 \%$ exceeded the QCO of $<15 \%$} \\
\hline (ICP-AES) & $\mathrm{U}_{\mathrm{B}}$ & \multicolumn{3}{|c|}{$\begin{array}{l}\text { The blank value was approximately } 35 \% \text { of the average analysis } \\
\text { value, thus exceeding the } 5 \% \text { blank maximum in the QCO. The } \\
\text { blank value reflects the fact that the measurements were near the } \\
\text { detection limit. }\end{array}$} \\
\hline (ICP-AES) & $\mathrm{U}_{\mathrm{R}}, \mathrm{U}_{\mathrm{M}}$ & \multicolumn{3}{|c|}{$\begin{array}{l}\text { The } \% \text { RSD of three determinations could not be calculated because } \\
\text { one of the determinations was below the detection limit. However, } \\
\text { precision of the three measurements was clearly }>15 \% \text { RSD, thus } \\
\text { requiring a QC flag for precision. Also, since one of the } \\
\text { measurements was below the detection limit that was in turn higher } \\
\text { than the MRQ, the determinations were also flagged for not } \\
\text { meeting the MRQ. }\end{array}$} \\
\hline \multicolumn{3}{|c|}{$\begin{array}{l}\text { QC Flags: - - meets all QC } \\
U_{B} \text { - blank exceeds } 5 \% \text { of sample concentration } \\
U_{0^{-}} \text {Outlier omitted in reported average analysis }\end{array}$} & $\begin{array}{l}U_{R} \text { - fails \% RSD criteria } \\
U_{L} \text { - fails \% Recovery of LCS } \\
\text { N/A - not applicable }\end{array}$ & $\begin{array}{l}U_{M} \text { - fails minimum MRQ criteria } \\
U_{S} \text { - fails \% Recovery of MS }\end{array}$ \\
\hline
\end{tabular}




\subsection{COMPARISON OF ELEMENTAL ANALYSES OF THE AY-102/C-106 SOLIDS FRACTION FROM THE THREE DIGESTION METHODS USED}

Three separate digestion methods were required for analysis of all elements listed in the Test Specification. Although a preferred or optimum digestion method for each element can be selected (Section 7.16), it is also useful to compare the determinations from all three digestions as shown in Table 7-14. The \% RSD of all elemental determinations composited from all three digestions was $15 \%$ or less for 36 of the 54 elemental or isotopic determinations (Stable I-127 is listed in Table 7-14, but since no attempt was made to measure stable iodine from any of the digestions, we do not include it in the performance assessment). The Quality Control Objective was $<15 \% \mathrm{RSD}$ for all elements except $\mathrm{Na}$ (3.5\% RSD). Since the composite measurement precision for $\mathrm{Na}$ was 13\% RSD, the precision Quality Control Objective was met for 35 of the 54 elemental or isotopic measurements. The composite determinations of only 10 elements (Ag, Bi, P, Pu, S, Tc, V, W, Zn, and Zr) were greater than $15 \%$ RSD. Therefore, including $\mathrm{Na}$, the precision Quality Control Objective was exceeded for only 11 elements. Eight elements (As, Be, Mo, Pd, Pt, Rb, Sb, and $\mathrm{Se}$ ), had concentrations below the detection limit, precluding a \% RSD calculation.

The differences in average concentrations and \% RSD obtained from the three digestions are generally consistent with the strengths and weaknesses of the digestion methods discussed previously. However, one exception is $\mathrm{P}$. We have no explanation for why the $\mathrm{P}$ determinations from the hot aqua regia digestions were so markedly lower than from the $\mathrm{KOH}-\mathrm{KNO}_{3}$ fusion and the hot mixed acid digestions. Also note that we chose to discard as a statistical outlier the first analysis of Ti from the aqua regia digestion since this determination met our arbitrary definition of an outlier of being over a factor of five different than the average of the other two determinations.

In Table 7-14, the average analysis and \% RSD are based on all the measurements that were above the detection limit obtained from the three digestion method. Measurements below the detection limit are shown to provide information on the detection limit, but they were not used in the composite concentration or composite precision calculations. For example, Bi determinations were obtained only from the hot aqua regia and $\mathrm{KOH}$ fusion digestions. The $\mathrm{B}$ determinations were obtained only from the $\mathrm{KOH}$ fusions because of detection limit issues with the hot aqua regia digestion and the fact that boric acid was added in the mixed-acid digestion to preclude $\mathrm{B}$ determination from this method. The data were more limited in the mixed acid digestion, not because of inherent inadequacies of this method, but because only a limited number of elements were analyzed as part of the routine ICP-AES suite of elements ( $\mathrm{Na}$ was the key element from this digestion and analysis). 
Table 7-14. Comparison of Elemental Analyses of AY-102/C-106 Solids Fraction from the Three Digestion Methods Used: Hot Aqua Regia, KOH Fusion, and $\mathrm{Hot} \mathrm{HF}-\mathrm{HNO}_{3}-\mathrm{HCl}-\mathrm{H}_{3} \mathrm{BO}_{3}$

Concentrations are on Wet Solids Basis

\begin{tabular}{|c|c|c|c|c|c|c|c|c|c|c|c|}
\hline \multirow[b]{2}{*}{ Analyte } & \multicolumn{3}{|c|}{$\begin{array}{l}\text { Triplicate Analyses of Hot } \\
\text { Aqua Regia Digestions }\end{array}$} & \multicolumn{3}{|c|}{$\begin{array}{l}\text { Triplicate Analyses of } \\
\text { KOH fusion Digestions }\end{array}$} & \multicolumn{3}{|c|}{ 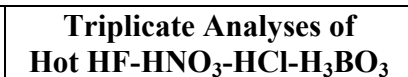 } & \multirow{2}{*}{\begin{tabular}{|c|} 
Average \\
Analysis \\
of all \\
Digest. \\
(mg/kg)
\end{tabular}} & \multirow{2}{*}{ 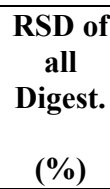 } \\
\hline & $\begin{array}{c}\text { 1st } \\
\text { Analysis } \\
\text { (mg/kg) }\end{array}$ & $\begin{array}{c}\text { 2nd } \\
\text { Analysis } \\
(\mathrm{mg} / \mathrm{kg})\end{array}$ & $\begin{array}{c}\text { 3rd } \\
\text { Analysis } \\
(\mathrm{mg} / \mathrm{kg})\end{array}$ & $\begin{array}{c}\text { 1st } \\
\text { Analysis } \\
(\mathrm{mg} / \mathrm{kg})\end{array}$ & $\begin{array}{c}\text { 2nd } \\
\text { Analysis } \\
(\mathrm{mg} / \mathrm{kg})\end{array}$ & $\begin{array}{c}\text { 3rd } \\
\text { Analysis } \\
(\mathrm{mg} / \mathrm{kg})\end{array}$ & $\begin{array}{c}\text { 1st } \\
\text { Analysis } \\
\text { (mg/kg) }\end{array}$ & $\begin{array}{c}\text { 2nd } \\
\text { Analysis } \\
(\mathrm{mg} / \mathrm{kg})\end{array}$ & $\begin{array}{c}\text { 3rd } \\
\text { Analysis } \\
\text { (mg/kg) }\end{array}$ & & \\
\hline $\mathrm{Ag}$ & 344 & 876 & 450 & 1,190 & 1,320 & 1,290 & 162 & 256 & 207 & 677 & $73 \%$ \\
\hline $\mathrm{Al}$ & 30,100 & 29,800 & 31,900 & 33,200 & 30,400 & 32,300 & 35,100 & 35,600 & 38,500 & 33,000 & $9 \%$ \\
\hline As & $<20$ & $<20$ & $<20$ & \multicolumn{3}{|c|}{ Not determined on fusions } & \multicolumn{3}{|c|}{ Not determ. on this digestion } & $<20$ & N/A \\
\hline $\mathrm{B}$ & $<74$ & $<137$ & $<137$ & 31 & 25 & 24 & \multicolumn{3}{|c|}{ Not determ. on this digestion } & & \\
\hline $\mathrm{Ba}$ & 418 & 417 & 464 & 509 & 477 & 500 & 432 & 428 & 449 & 455 & $8 \%$ \\
\hline $\mathrm{Be}$ & $<2$ & $<4$ & $<4$ & $<2$ & $<2$ & $<5$ & $<1$ & $<1$ & $<1$ & $<5$ & N/A \\
\hline $\mathrm{Bi}$ & 24 & 23 & 27 & 18 & 18 & 17 & \multicolumn{3}{|c|}{ Not determ. on this digestion } & 21 & $19 \%$ \\
\hline $\mathrm{Ca}$ & 2,280 & 2,300 & 2,530 & 2,550 & 2,340 & 2,600 & 2,590 & 2,550 & 2,700 & 2,500 & $6 \%$ \\
\hline $\mathrm{Cd}$ & 75 & 79 & 78 & 105 & 97 & 101 & 86 & 87 & 97 & 89 & $12 \%$ \\
\hline $\mathrm{Ce}$ & 628 & 642 & 637 & 650 & 650 & 659 & \multicolumn{3}{|c|}{ Not determ. on this digestion } & 644 & $2 \%$ \\
\hline $\mathrm{Co}$ & 23 & 22 & 23 & 17 & 18 & 17 & \multicolumn{3}{|c|}{ Not determ. on this digestion } & 20 & $15 \%$ \\
\hline $\mathrm{Cr}$ & 1,120 & 1,160 & 1,250 & 1,320 & 1,230 & 1,290 & 1,200 & 1,310 & 1,330 & 1,250 & $6 \%$ \\
\hline${ }^{133} \mathrm{Cs}$ & 9 & 9 & 9 & \multicolumn{3}{|c|}{ Not determined on fusions } & \multicolumn{3}{|c|}{ Not determ. on this digestion } & 9 & $2 \%$ \\
\hline${ }^{135} \mathrm{Cs}$ & 4 & 4 & 5 & \multicolumn{3}{|c|}{ Not determined on fusions } & \multicolumn{3}{|c|}{ Not determ. on this digestion } & 4 & $3 \%$ \\
\hline${ }^{137} \mathrm{Cs}$ & 3 & 3 & 3 & \multicolumn{3}{|c|}{ Not determined on fusions } & \multicolumn{3}{|c|}{ Not determ. on this digestion } & 3 & $5 \%$ \\
\hline Cs-total & 16 & 16 & 17 & \multicolumn{3}{|c|}{ Not determined on fusions } & \multicolumn{3}{|c|}{ Not determ. on this digestion } & 16 & $4 \%$ \\
\hline $\mathrm{Cu}$ & 170 & 177 & 175 & 131 & 150 & 138 & \multicolumn{3}{|c|}{ Not determ. on this digestion } & 157 & $13 \%$ \\
\hline $\mathrm{Fe}$ & 65,800 & 65,000 & 72,600 & 74,100 & 69,600 & 75,000 & 74,600 & 73,800 & 83,200 & 72,600 & $8 \%$ \\
\hline $\begin{array}{c}\mathrm{Hg} \\
(\mathrm{SRTC})\end{array}$ & 148 & 150 & 143 & \multicolumn{3}{|c|}{ Not determined on fusions } & \multicolumn{3}{|c|}{ Not determ. on this digestion } & 147 & $2 \%$ \\
\hline $\mathrm{I}-127$ & \multicolumn{11}{|c|}{ No SRTC method for stable iodine at trace concentrations } \\
\hline $\mathrm{K}$ & 420 & 415 & 425 & \multicolumn{3}{|c|}{ Not determined on fusions } & \multirow{2}{*}{\multicolumn{3}{|c|}{$\begin{array}{l}\text { Not determ. on this digestion } \\
\text { Not determ. on this digestion }\end{array}$}} & 420 & $1 \%$ \\
\hline $\mathrm{La}$ & 426 & 424 & 470 & 468 & 432 & 491 & & & & 452 & $6 \%$ \\
\hline $\mathrm{Li}$ & 188 & $<210$ & $<210$ & 228 & 197 & 275 & 208 & 206 & 230 & 219 & $13 \%$ \\
\hline $\mathrm{Mg}$ & 604 & 600 & 658 & 691 & 636 & 695 & 655 & 661 & 793 & 666 & $9 \%$ \\
\hline $\mathrm{Mn}$ & 14,200 & 14,400 & 15,800 & 16,000 & 14,800 & 16,000 & 15,800 & 15,500 & 17,500 & 15,600 & $6 \%$ \\
\hline Mo & $<15$ & $<15$ & $<15$ & Not dete & rmined on & fusions & Not detern & n. on this $d$ & Jestion & $<15$ & N/A \\
\hline $\mathrm{Na}$ & 59,900 & 55,300 & 60,400 & 76,400 & 68,600 & 80,900 & 68,000 & 69,100 & 73,800 & 67,300 & $13 \%$ \\
\hline $\mathrm{Ni}$ & 2,140 & 2,110 & 2,270 & 2,470 & 2,300 & 2,450 & 2,400 & 2,520 & 2,550 & 2,360 & $7 \%$ \\
\hline $\mathrm{Nd}$ & 880 & 900 & 910 & 982 & 1027 & 964 & Not dete & m. on this & igestion & 944 & $6 \%$ \\
\hline $\mathrm{P}$ & 1,080 & 1,260 & 1,590 & 3,290 & 3,000 & 3,120 & 2,670 & 2,520 & 2,560 & 2,340 & $35 \%$ \\
\hline $\mathrm{Pb}$ & 3,260 & 3,310 & 3,250 & 3,270 & 3,340 & 3,260 & 3,350 & 3,310 & 3,670 & 3,340 & $4 \%$ \\
\hline $\mathrm{Pd}$ & $<50$ & $<50$ & $<50$ & Not dete & rmined on & usions & Not dete & m. on this & igestion & $<50$ & $\mathrm{~N} / \mathrm{A}$ \\
\hline
\end{tabular}


WSRC-TR-2003-00205, REVISION 0

SRT-RPP-2003-00086, REVISION 0

Table 7-14. Comparison of Elemental Analyses of AY-102/C-106 Solids Fraction from the Three Digestion Methods Used: Hot Aqua Regia, KOH Fusion, and Hot $\mathrm{HF}-\mathrm{HNO}_{3}-\mathrm{HCl}-\mathrm{H}_{3} \mathrm{BO}_{3}-$ page 2 of 2

Concentrations are on Wet Solids Basis

\begin{tabular}{|c|c|c|c|c|c|c|c|c|c|c|c|}
\hline \multirow[b]{2}{*}{ Analyte } & \multicolumn{3}{|c|}{$\begin{array}{l}\text { Triplicate Analyses of Hot } \\
\text { Aqua Regia Digestions }\end{array}$} & \multicolumn{3}{|c|}{$\begin{array}{c}\text { Triplicate Analyses of } \\
\text { KOH fusion Digestions }\end{array}$} & \multicolumn{3}{|c|}{$\begin{array}{c}\text { Triplicate Analyses of } \\
\text { Hot } \mathrm{HF}-\mathrm{HNO}_{3}-\mathrm{HCl}-\mathrm{H}_{3} \mathrm{BO}_{3}\end{array}$} & \multirow{2}{*}{$\begin{array}{c}\text { Average } \\
\text { Analysis } \\
\text { of all } \\
\text { Digest. } \\
\text { (mg/kg) } \\
\end{array}$} & \multirow{2}{*}{$\begin{array}{c}\text { RSD of } \\
\text { all } \\
\text { Digest. } \\
(\%) \\
\end{array}$} \\
\hline & \begin{tabular}{|c|} 
1st \\
Analysis \\
$(\mathrm{mg} / \mathrm{kg})$
\end{tabular} & $\begin{array}{c}\text { 2nd } \\
\text { Analysis } \\
\text { (mg/kg) }\end{array}$ & \begin{tabular}{|c|} 
3rd \\
Analysis \\
$(\mathbf{m g} / \mathbf{k g})$ \\
\end{tabular} & $\begin{array}{c}\text { 1st } \\
\text { Analysis } \\
(\mathrm{mg} / \mathrm{kg})\end{array}$ & \begin{tabular}{|c|} 
2nd \\
Analysis \\
(mg/kg)
\end{tabular} & $\begin{array}{c}\text { 3rd } \\
\text { Analysis } \\
(\mathrm{mg} / \mathrm{kg}) \\
\end{array}$ & \begin{tabular}{|c|} 
1st \\
Analysis \\
$(\mathrm{mg} / \mathrm{kg})$
\end{tabular} & $\begin{array}{c}\text { 2nd } \\
\text { Analysis } \\
(\mathrm{mg} / \mathrm{kg})\end{array}$ & $\begin{array}{c}\text { 3rd } \\
\text { Analysis } \\
(\mathrm{mg} / \mathrm{kg})\end{array}$ & & \\
\hline $\operatorname{Pr}$ & 249 & 253 & 255 & 281 & 288 & 277 & \multicolumn{3}{|c|}{ Not determ. on this digestion } & 267 & $6 \%$ \\
\hline $\mathrm{Pt}$ & $<3$ & $<3$ & $<3$ & $<5$ & $<5$ & $<5$ & \multicolumn{3}{|c|}{ Not determ. on this digestion } & $<5$ & $\mathrm{~N} / \mathrm{A}$ \\
\hline $\mathrm{Pu}$ & 14 & 22 & 17 & \multicolumn{3}{|c|}{ Not determined on fusions } & \multicolumn{3}{|c|}{ Not determ. on this digestion } & 18 & $25 \%$ \\
\hline $\mathrm{Rb}$ & $<6$ & $<6$ & $<6$ & \multicolumn{3}{|c|}{ Not determined on fusions } & \multirow{2}{*}{\multicolumn{3}{|c|}{$\begin{array}{l}\text { Not determ. on this digestion } \\
\text { Not determ. on this digestion }\end{array}$}} & $<6$ & $\mathrm{~N} / \mathrm{A}$ \\
\hline $\mathrm{Rh}$ & 21 & 19 & 22 & 21 & 22 & 21 & & & & 21 & $5 \%$ \\
\hline $\mathrm{Ru}$ & 233 & 229 & 221 & 232 & 223 & 234 & \multicolumn{3}{|c|}{ Not determ. on this digestion } & 229 & $2 \%$ \\
\hline $\mathrm{S}$ & 674 & 586 & 670 & 882 & 782 & 836 & 900 & 825 & 1,120 & 808 & $20 \%$ \\
\hline $\mathrm{Sb}$ & $<6$ & $<6$ & $<6$ & \multicolumn{3}{|c|}{ Not determined on fusions } & \multicolumn{3}{|c|}{ Not determ. on this digestion } & $<6$ & $\mathrm{~N} / \mathrm{A}$ \\
\hline $\mathrm{Se}$ & $<20$ & $<20$ & $<20$ & \multicolumn{3}{|c|}{ Not determined on fusions } & \multirow{2}{*}{\multicolumn{3}{|c|}{$\begin{array}{l}\text { Not determ. on this digestion } \\
\text { Not determ. on this digestion }\end{array}$}} & $<20$ & N/A \\
\hline $\mathrm{Si}$ & \multicolumn{3}{|c|}{ Not determ. on this digestion } & 21,300 & 19,700 & 20,800 & & & & 20,600 & $4 \%$ \\
\hline $\mathrm{Sr}$ & 563 & 571 & 626 & 618 & 568 & 600 & \multicolumn{3}{|c|}{ Not determ. on this digestion } & 591 & $5 \%$ \\
\hline $\mathrm{Ta}$ & $<6$ & $<6$ & $<6$ & 10 & 10 & 10 & \multicolumn{3}{|c|}{ Not determ. on this digestion } & 10 & $3 \%$ \\
\hline $\mathrm{Tc}$ & 4 & 4 & 2 & \multicolumn{3}{|c|}{ Not determined on fusions } & \multirow{2}{*}{\multicolumn{3}{|c|}{$\begin{array}{l}\text { Not determ. on this digestion } \\
\text { Not determ. on this digestion }\end{array}$}} & 3 & $29 \%$ \\
\hline $\mathrm{Te}$ & 30 & 30 & 30 & 32 & 34 & 33 & & & & 32 & $6 \%$ \\
\hline $\mathrm{Th}$ & 435 & 459 & 461 & 509 & 491 & 473 & \multicolumn{3}{|c|}{ Not determ. on this digestion } & 471 & $6 \%$ \\
\hline $\mathrm{Ti}$ & $24\left(\mathrm{U}_{\mathrm{o}}\right)$ & $<38$ & $<38$ & 145 & 133 & 152 & \multicolumn{3}{|c|}{ Not determ. on this digestion } & 143 & $7 \%$ \\
\hline $\mathrm{Tl}$ & $<5$ & $<5$ & $<5$ & 2 & 2 & 2 & \multicolumn{3}{|c|}{ Not determ. on this digestion } & 2 & $6 \%$ \\
\hline $\mathrm{U}$ & 2,100 & 2,190 & 2,190 & 2,360 & 2,570 & 2,410 & \multicolumn{3}{|c|}{ Not determ. on this digestion } & 2,300 & $8 \%$ \\
\hline $\mathrm{V}$ & 8.0 & $<10$ & $<10$ & 9 & 119 & 12 & 24 & 24 & 29 & 17 & $52 \%$ \\
\hline $\mathrm{W}$ & 164 & 184 & 268 & 258 & 245 & 240 & \multicolumn{3}{|c|}{ Not determ. on this digestion } & 227 & $18 \%$ \\
\hline $\mathrm{Y}$ & 102 & 103 & 102 & 122 & 131 & 122 & \multicolumn{3}{|c|}{ Not determ. on this digestion } & 114 & $11 \%$ \\
\hline $\mathrm{Zn}$ & 112 & 86 & 129 & 211 & 187 & 198 & $<3$ & 8.0 & 19 & 119 & $66 \%$ \\
\hline $\mathrm{Zr}$ & 208 & 850 & 498 & \multicolumn{3}{|c|}{ Not determined on fusions } & 2,450 & 2,410 & 2,840 & 1,540 & $75 \%$ \\
\hline
\end{tabular}




\subsection{ELEMENTAL COMPOSITION OF AY-102/C-106 SOLID FRACTION BASED ON SELECTION OF PREFERRED DIGESTION METHOD FOR EACH ELEMENT}

Unfortunately, no single dissolution method provides an optimum determination for all elements requested in the Test Specification. Table 7-15 is a distillation of the elemental analyses from the three digestion procedures into our "preferred" reportable analysis of the AY-102 solid fraction. The $\mathrm{KOH}-\mathrm{KNO}_{3}$ fusion is our preferred digestion for most elements ( 36 of 51) because this digestion is rigorous and provides the most reliable determination for most analytes. As discussed in Section 7.1.3, certain elements are precluded from reliable determination by the $\mathrm{KOH} / \mathrm{KNO}_{3}$ fusion because of analyte volatility, and either chemical or spectroscopic interference problems. The aqua regia digestion is used to report 12 elements for which the fusion digestion is considered inadequate.

Three elements, $\mathrm{Be}, \mathrm{Li}$, and $\mathrm{Zr}$ are reported on the hot $\mathrm{HF}-\mathrm{HNO}_{3}-\mathrm{HCl}-\mathrm{H}_{3} \mathrm{BO}_{3}$ digestion.

- $\mathrm{Be}$ is reported on this digestion because of the effectiveness of $\mathrm{HF}$ to dissolve $\mathrm{BeO}$.

- $\mathrm{Li}$ is also reported on this digestion because it is unlikely to have Li contamination. The Li determination from the aqua regia digestion should also be acceptable, but the ICP-AES detection limits were inadequate for the aqua regia determinations and preclude reporting this value.

- $\mathrm{Zr}$ is also reported from the $\mathrm{HF}-\mathrm{HNO}_{3}-\mathrm{HCl}-\mathrm{H}_{3} \mathrm{BO}_{3}$ digestion because of the solubility of many $\mathrm{Zr}$ compounds in HF.

The QC flags of the determinations selected for reporting the preferred elemental analyses based on type of digestion were previously discussed in the QC flag comment sections associated with each digestion method. The QC flags for the preferred elemental analyses were relegated to only trace components except for $\mathrm{Na}$. It is difficult to perform a shielded cell digestion and obtain $3.5 \% \mathrm{RSD}$ on $\mathrm{Na}$. We obtained about $8 \% \mathrm{RSD}$ on $\mathrm{Na}$ from the $\mathrm{KOH}$ fusion. We consider this precision for Na typical of cell digestions and analyses of sludge samples performed at SRTC. With more replicate determinations, $3.5 \%$ RSD for Na could be achieved. However, we believe it is important that the typical laboratory performance be captured in this report and, therefore, we chose to report the $8 \%$ RSD for Na.

Another factor in choosing the $\mathrm{KOH}$ fusion digestion to report most elements is that we obtained somewhat better data on the concurrent analysis of Analytical Reference Glass-1 (ARG-1) with this digestion versus the hot aqua regia. Table 7-16 compares the values obtained from both digestions. An apparent low bias of about $10 \%$ relative was observed with the aqua regia digestion. Since the KOH fusion values of the AY-102/C-106 solids were in general about 5-10\% higher than the aqua regia determinations, we suspect a systematic error was introduced in the aqua regia digestions. 
The Analytical Reference Glass-1 was developed as a de facto standard by SRTC and the SRS Defense Waste Processing Facility (DWPF) in the early1990s through a combined effort of PNNL, SRTC, and the Corning Engineering Laboratory- reference: SRL's Performance in Analytical Round Robin \#6-Analyses of Simulated Defense Waste Glass, WSRC-TR-91-187, May 31, 1991, C.J. Coleman, author. Concurrent analysis of the crushed glass standard is used to help measure the accuracy of both sludge and glass analyses at SRTC and the SRS Defense Waste Processing Facility (DWPF).

Table 7-15. Elemental Composition of AY-102/C-106 Solids Fraction Based on Selection of Preferred Digestion Method for Each Element on Both Wet Solids Basis and Dry Solids Basis

Wet to Dry Conversion Factor is $\mathbf{2 . 2}$

\begin{tabular}{|c|c|c|c|c|}
\hline Analyte & $\begin{array}{c}\text { Digestion Method } \\
\text { Used for } \\
\text { Determination } \\
\end{array}$ & $\begin{array}{c}\text { Average Analysis } \\
\text { On Wet Solids Basis } \\
(\mathrm{mg} / \mathrm{kg})\end{array}$ & $\begin{array}{c}\text { Average Analysis } \\
\text { On Dry Solids Basis } \\
(\mathrm{mg} / \mathrm{kg})\end{array}$ & QC Flag \\
\hline $\mathrm{Ag} \quad$ (ICP-MS) & KOH Fusion & 1,290 & 2,840 & - \\
\hline $\mathrm{Al}$ (ICP-AES) & KOH Fusion & 32,300 & 71,000 & - \\
\hline As $\quad$ (AAS) & Aqua Regia & $<20$ & $<44$ & $\mathrm{U}_{\mathrm{M}}$ \\
\hline B (ICP-AES) & KOH Fusion & 24 & 52 & $\mathrm{U}_{\mathrm{R}}$ \\
\hline $\mathrm{Ba}$ (ICP-AES) & KOH Fusion & 500 & 1,100 & - \\
\hline $\mathrm{Be}$ (ICP-AES) & $\begin{array}{c}\text { HF-HNO } \mathrm{HN}_{3} \text {-HCl- } \\
\mathrm{H}_{3} \mathrm{BO}_{3}\end{array}$ & $<1$ & $<2$ & - \\
\hline $\mathrm{Bi} \quad$ (ICP-MS) & Aqua Regia & 25 & 55 & - \\
\hline $\mathrm{Ca}$ (ICP-AES) & KOH Fusion & 2,500 & 5,500 & - \\
\hline $\mathrm{Cd} \quad$ (ICP-MS) & KOH Fusion & 100 & 222 & - \\
\hline $\mathrm{Ce} \quad$ (ICP-MS) & KOH Fusion & 660 & 1,450 & - \\
\hline Co (ICP-MS) & KOH Fusion & 17 & 38 & - \\
\hline $\mathrm{Cr}$ (ICP-AES) & KOH Fusion & 1,290 & 2,830 & - \\
\hline $\begin{array}{l}\text { Cs (sum of } \\
\text { isotopes from } \\
\text { ICP-MS and } \\
\text { counting) }\end{array}$ & Aqua Regia & 9 & 20 & $\mathrm{U}_{\mathrm{B}}$ \\
\hline $\mathrm{Cu}$ (ICP-MS) & KOH Fusion & 140 & 304 & - \\
\hline $\mathrm{Fe} \quad$ (ICP-AES) & $\mathrm{KOH}$ Fusion & 72,900 & 160,000 & - \\
\hline $\mathrm{Hg} \quad$ (AAS) & Aqua Regia & 147 & 323 & - \\
\hline $\mathrm{K} \quad$ (AAS) & Aqua Regia & 420 & 924 & - \\
\hline $\mathrm{La}$ (ICP-AES) & KOH Fusion & 460 & 1,020 & - \\
\hline \multicolumn{2}{|c|}{$\begin{array}{l}\text { QC Flags: - - meets all QC } \\
\mathrm{U}_{\mathrm{B}} \text { - blank exceeds } 5 \% \text { of sample concentration } \\
\mathrm{U}_{\mathrm{O}^{-}} \text {Outlier omitted in reported average analysis }\end{array}$} & $\begin{array}{l}U_{R} \text { - fails \% RSD criteric } \\
U_{L} \text { - fails \% Recovery of } \\
\text { N/A - not applicable }\end{array}$ & $\begin{array}{l}U_{\mathrm{M}} \text { - fails min. repo } \\
U_{\mathrm{S}} \text { - fails \% Recove }\end{array}$ & $\begin{array}{l}\text { le quantity } \\
\text { f MS }\end{array}$ \\
\hline
\end{tabular}


Table 7-15. Elemental Composition of AY-102/C-106 Solid Fraction Based on Selection of Preferred Digestion Method for Each Element on Both Wet Solids Basis and Dry Solids Basis - page 2 of 3

Wet to Dry Conversion Factor is 2.2

\begin{tabular}{|c|c|c|c|c|}
\hline Analyte & $\begin{array}{c}\text { Digestion Method } \\
\text { Used for } \\
\text { Determination }\end{array}$ & $\begin{array}{c}\text { Average Analysis } \\
\text { On Wet Solids Basis } \\
(\mathrm{mg} / \mathrm{kg})\end{array}$ & $\begin{array}{c}\text { Average Analysis } \\
\text { On Dry Solids Basis } \\
(\mathrm{mg} / \mathrm{kg})\end{array}$ & QC Flag \\
\hline $\mathrm{Li} \quad$ (ICP-AES) & $\begin{array}{c}\text { HF- } \mathrm{HNO}_{3} \text {-HCl- } \\
\mathrm{H}_{3} \mathrm{BO}_{3}\end{array}$ & 215 & 473 & $\mathrm{U}_{\mathrm{R}}$ \\
\hline $\mathrm{Mg}$ (ICP-AES) & KOH Fusion & 670 & 1,480 & - \\
\hline Mn (ICP-AES) & KOH Fusion & 15,600 & 34,300 & - \\
\hline Mo (ICP-MS) & Aqua Regia & $<15$ & $<33$ & - \\
\hline $\mathrm{Na}$ (ICP-AES) & KOH Fusion & 75,300 & 166,000 & $\begin{array}{l}\mathrm{U}_{\mathrm{R}}, \mathrm{U}_{\mathrm{L}} \\
\mathrm{U}_{\mathrm{S}}\end{array}$ \\
\hline $\mathrm{Ni} \quad$ (ICP-AES) & KOH Fusion & 2,410 & 5,300 & - \\
\hline $\mathrm{Nd}$ (ICP-MS) & KOH Fusion & 990 & 2,180 & - \\
\hline $\mathrm{P} \quad$ (ICP-AES) & KOH Fusion & 3,100 & 6,860 & - \\
\hline $\mathrm{Pb} \quad$ (ICP-MS) & KOH Fusion & 3,260 & 7,170 & - \\
\hline $\mathrm{Pd} \quad$ (ICP-MS) & Aqua Regia & $<50$ & $<110$ & - \\
\hline $\operatorname{Pr} \quad$ (ICP-MS) & KOH Fusion & 280 & 620 & - \\
\hline $\mathrm{Pt} \quad$ (ICP-MS) & KOH Fusion & $<5$ & $<10$ & $\mathrm{U}_{\mathrm{M}}$ \\
\hline $\begin{array}{l}\mathrm{Pu} \quad \text { (sum of } \\
\text { isotopes-ICP-MS } \\
\text { and Counting) }\end{array}$ & Aqua Regia & 18 & 40 & - \\
\hline $\mathrm{Rb}$ (ICP-MS) & Aqua Regia & $<6$ & $<13$ & - \\
\hline $\mathrm{Rh}$ (ICP-MS) & KOH Fusion & 21 & 47 & - \\
\hline Ru (ICP-MS) & KOH Fusion & 230 & 505 & - \\
\hline $\mathrm{S} \quad$ (ICP-AES) & KOH Fusion & 830 & 1,830 & - \\
\hline $\mathrm{Sb} \quad$ (ICP-MS) & Aqua Regia & $<6$ & $<13$ & - \\
\hline $\mathrm{Se} \quad$ (AAS) & Aqua Regia & $<20$ & $<44$ & $\mathrm{U}_{\mathrm{S}}$ \\
\hline $\mathrm{Si} \quad$ (ICP-AES) & KOH Fusion & 20,600 & 45,400 & - \\
\hline $\mathrm{Sr} \quad$ (ICP-AES) & KOH Fusion & 600 & 1,320 & - \\
\hline \multicolumn{2}{|c|}{$\begin{array}{l}\text { QC Flags: - - meets all QC } \\
\mathrm{U}_{\mathrm{B}} \text { - blank exceeds } 5 \% \text { of sample concentration } \\
\mathrm{U}_{\mathrm{O}} \text { - Outlier omitted in reported average analysi }\end{array}$} & $\begin{array}{l}\mathrm{U}_{\mathrm{R}} \text { - fails \% RSD criteri } \\
\mathrm{U}_{\mathrm{L}} \text { - fails \% Recovery o } \\
\text { N/A - not applicable }\end{array}$ & \multicolumn{2}{|c|}{$\begin{array}{l}U_{M} \text { - fails min. reportable quantity } \\
U_{S} \text { - fails \% Recovery of MS }\end{array}$} \\
\hline
\end{tabular}


WSRC-TR-2003-00205, REVISION 0

SRT-RPP-2003-00086, REVISION 0

Table 7-15. Elemental Composition of AY-102/C-106 Solid Fraction Based on Selection of Preferred Digestion Method for Each Element on Both Wet Solids Basis and Dry Solids Basis - page 3 of 3

Wet to Dry Conversion Factor is $\mathbf{2 . 2}$

\begin{tabular}{|c|c|c|c|c|}
\hline Analyte & $\begin{array}{c}\text { Digestion Method } \\
\text { Used for } \\
\text { Determination } \\
\end{array}$ & $\begin{array}{c}\text { Average Analysis } \\
\text { On Wet Solids Basis } \\
(\mathrm{mg} / \mathrm{kg})\end{array}$ & $\begin{array}{c}\text { Average Analysis } \\
\text { On Dry Solids Basis } \\
(\mathrm{mg} / \mathrm{kg})\end{array}$ & QC Flag \\
\hline $\mathrm{Ta} \quad$ (ICP-MS) & KOH Fusion & 10 & 22 & - \\
\hline Tc (counting) & Aqua Regia & 3 & 6 & $\mathrm{U}_{\mathrm{R}}$ \\
\hline $\mathrm{Te} \quad$ (ICP-MS) & KOH Fusion & 33 & 72 & - \\
\hline Th (ICP-MS) & KOH Fusion & 490 & 1,080 & - \\
\hline $\mathrm{Ti} \quad$ (ICP-AES) & KOH Fusion & 143 & 315 & - \\
\hline Tl (ICP-MS) & KOH Fusion & 2 & 4 & - \\
\hline $\mathrm{U} \quad$ (ICP-MS) & KOH Fusion & 2,450 & 5,390 & - \\
\hline $\mathrm{V} \quad$ (ICP-AES) & KOH Fusion & 10 & 23 & $\mathrm{U}_{\mathrm{R}}$ \\
\hline $\mathrm{W} \quad$ (ICP-MS) & KOH Fusion & 245 & 544 & - \\
\hline $\mathrm{Y} \quad$ (ICP-MS) & KOH Fusion & 124 & 274 & - \\
\hline $\mathrm{Zn}$ (ICP-AES) & $\mathrm{KOH}$ Fusion & 199 & 437 & - \\
\hline $\mathrm{Zr} \quad$ (ICP-AES) & $\begin{array}{c}\mathrm{HF}-\mathrm{HNO}_{3} \text {-HCl- } \\
\mathrm{H}_{3} \mathrm{BO}_{3}\end{array}$ & 2,570 & 5,650 & - \\
\hline \multicolumn{2}{|c|}{$\begin{array}{l}\text { QC Flags: - - meets all QC } \\
\mathrm{U}_{\mathrm{B}} \text { - blank exceeds } 5 \% \text { of sample concentration } \\
\mathrm{U}_{\mathrm{O}^{-}} \text {Outlier omitted in reported average analysis }\end{array}$} & \multicolumn{3}{|c|}{$\begin{array}{l}U_{M} \text { - fails min. reportable quantity } \\
U_{S} \text { - fails \% Recovery of MS }\end{array}$} \\
\hline
\end{tabular}


Table 7-16. Comparison of Elemental Analysis of the Analytical Reference Glass-1 Following Digestion with Hot Aqua Regia or $\mathrm{KOH} / \mathrm{KNO}_{3}$ Fusion

Note: These determinations were performed concurrently with the AY-102/C-106 determinations.

\begin{tabular}{|c|c|c|c|c|c|}
\hline Element & $\begin{array}{l}\text { Standard } \\
\text { Value in } \\
\text { Glass } \\
(\mu \mathrm{g} / \mathrm{g})\end{array}$ & $\begin{array}{l}\text { Measured } \\
\text { Value Hot } \\
\text { Aqua Regia } \\
\text { Digestion } \\
(\mu \mathrm{g} / \mathrm{g})\end{array}$ & $\begin{array}{l}\text { \% Difference } \\
\text { Measured vs. } \\
\text { Standard } \\
\text { Value - Hot } \\
\text { Aqua Regia } \\
\text { Digestion } \\
\end{array}$ & $\begin{array}{c}\text { Measured } \\
\text { Value KOH } \\
\text { Fusion } \\
\text { Digestion } \\
(\mu \mathrm{g} / \mathrm{g})\end{array}$ & $\begin{array}{c}\text { \% Difference } \\
\text { Measured vs. } \\
\text { Standard } \\
\text { Value - KOH } \\
\text { Fusion } \\
\text { Digestion } \\
\end{array}$ \\
\hline $\mathrm{Al}$ & 25,000 & 21,000 & $-16 \%$ & 22,900 & $-8 \%$ \\
\hline B & 26,900 & 24,700 & $-8 \%$ & 24,900 & $-7 \%$ \\
\hline $\mathrm{Ba}$ & 790 & 738 & $-7 \%$ & 890 & $+13 \%$ \\
\hline $\mathrm{Ca}$ & 10,200 & 9,370 & $-8 \%$ & 10,000 & $-2 \%$ \\
\hline $\mathrm{Cr}$ & 640 & 557 & $-13 \%$ & 740 & $+16 \%$ \\
\hline $\mathrm{K}$ & 22,600 & 20,000 & $-12 \%$ & $\mathrm{~N} / \mathrm{A}$ & $\mathrm{N} / \mathrm{A}$ \\
\hline $\mathrm{Li}$ & 14,900 & 14,300 & $-4 \%$ & 15,400 & $+3 \%$ \\
\hline $\mathrm{Mg}$ & 5,200 & 4,750 & $-9 \%$ & 5,170 & $+1 \%$ \\
\hline Mn & 14,600 & 13,300 & $-9 \%$ & 14,200 & $+3 \%$ \\
\hline $\mathrm{Na}$ & 85,200 & 74,700 & $-12 \%$ & 86,800 & $+2 \%$ \\
\hline $\mathrm{Ni}$ & 8,300 & 7,050 & $-15 \%$ & 7,830 & $-6 \%$ \\
\hline $\mathrm{P}$ & 1,100 & $<1,000$ & N/A & $<385$ & N/A \\
\hline $\mathrm{Si}$ & 224,000 & 31,600 & $-85 \%$ & 243,000 & $+8 \%$ \\
\hline $\mathrm{Sr}$ & 3,000 & 1,800 & $-40 \%$ & 1900 & $-37 \%$ \\
\hline $\mathrm{Ti}$ & 6,900 & 5,060 & $-27 \%$ & 6,540 & $-5 \%$ \\
\hline $\mathrm{Zn}$ & 160 & 50 & $-69 \%$ & 372 & $+133 \%$ \\
\hline $\mathrm{Zr}$ & 960 & $<160$ & N/A & N/A & N/A \\
\hline
\end{tabular}




\subsection{RADIONUCLIDE ANALYSES OF THE AY-102/C-106 SOLIDS FRACTION}

With the exception of ${ }^{14} \mathrm{C}$, the pertechnetate form of ${ }^{99} \mathrm{Tc},{ }^{129} \mathrm{I}$, and ${ }^{151} \mathrm{Sm}$, all radionuclides measured on the AY-102/C-106 solid fraction were first dissolved with the hot aqua regia method discussed previously in Section 7.1.2. ${ }^{151} \mathrm{Sm}$ determinations would also have been suitable from the aqua regia digestions, but the aqua regia digestions were consumed by other determinations before the ${ }^{151} \mathrm{Sm}$ determinations were performed. The digestions were removed from the shielded cells and analyzed with radiochemical separation and counting techniques to determine the radionuclides: ${ }^{3} \mathrm{H},{ }^{59} \mathrm{Ni},{ }^{63} \mathrm{Ni}{ }^{60} \mathrm{Co},{ }^{79} \mathrm{Se},{ }^{90} \mathrm{Sr},{ }^{99} \mathrm{Tc}$ (total) ${ }^{125} \mathrm{Sb},{ }^{126} \mathrm{Sb}+{ }^{126} \mathrm{Sn}$, ${ }^{137} \mathrm{Cs},{ }^{151} \mathrm{Sm},{ }^{152} \mathrm{Eu},{ }^{154} \mathrm{Eu},{ }^{155} \mathrm{Eu},{ }^{231} \mathrm{~Pa},{ }^{238} \mathrm{Pu},{ }^{239 / 240} \mathrm{Pu},{ }^{241} \mathrm{Pu},{ }^{241} \mathrm{Am},{ }^{243} \mathrm{Am},{ }^{242} \mathrm{Cm},{ }^{243 / 244} \mathrm{Cm}$, and total alpha.

Those radionuclides measured by counting techniques but prepared directly on the solid fraction to either increase sensitivity or to preserve oxidation state were ${ }^{14} \mathrm{C}$, the pertechnetate form of ${ }^{99} \mathrm{Tc}$, and ${ }^{129} \mathrm{I}$. Although the elemental analyses obtained from the aqua regia digestions averaged about 5-10\% lower than those from the $\mathrm{KOH}$ fusions, this difference (even if it represents a true low bias associated with the digestion) should have minimal effect on using the radionuclide concentration measurements for waste processing or regulatory waste compliance purposes. A significant increase in analytical costs would have been incurred if the radionuclides had been measured on all the digestions used for AY-102/C-106 solids.

Inductively Coupled Plasma-Mass Spectroscopy (ICP-MS) was used to measure the following radionuclides in the solid fraction with relatively long half-lives: ${ }^{135} \mathrm{Cs},{ }^{233} \mathrm{U},{ }^{234} \mathrm{U},{ }^{235} \mathrm{U},{ }^{236} \mathrm{U}$, ${ }^{238} \mathrm{U},{ }^{237} \mathrm{~Np},{ }^{239} \mathrm{Pu},{ }^{240} \mathrm{Pu}$. Note that ${ }^{239} \mathrm{Pu}$ and ${ }^{240} \mathrm{Pu}$ were measured by both counting and ICPMS techniques, and that these methods were in good agreement on Pu determinations.

The following ICP-MS procedure was used in the measurements:

Reference: ADS Procedure 1543: "Inductively Coupled Plasma-Mass Spectrometer," Issue Date: 9/15/2002, Author: M.A. Malek.

ICP-MS determinations of radionuclides were reported in $\mu \mathrm{g} / \mathrm{g}$ of the solids. To convert these values to $\mathrm{mCi} / \mathrm{kg}$ as required by the Test Specification, the specific activity of each radionuclide was used. The pertinent specific activities were obtained from "Integrated Data Base Report-1994: U.S. Spent Nuclear Fuel and Radioactive Waste Inventories, Projections, and Characteristics," Appendix B, pages 277,278, and 280, DOE/RW-0006, September, 1995, prepared by the Oak Ridge National Laboratory. 
WSRC-TR-2003-00205, REVISION 0

SRT-RPP-2003-00086, REVISION 0

\begin{tabular}{|c|c|}
\hline Radionuclide Determined by ICP-MS & Specific Activity of Radionuclide (Ci/g) \\
\hline${ }^{135} \mathrm{Cs}$ & $1.15 \mathrm{E}-3$ \\
\hline${ }^{233} \mathrm{U}$ & $9.68 \mathrm{E}-3$ \\
\hline${ }^{234} \mathrm{U}$ & $6.25 \mathrm{E}-3$ \\
\hline${ }^{235} \mathrm{U}$ & $2.16 \mathrm{E}-6$ \\
\hline${ }^{236} \mathrm{U}$ & $6.47 \mathrm{E}-5$ \\
\hline${ }^{238} \mathrm{U}$ & $3.36 \mathrm{E}-7$ \\
\hline${ }^{237} \mathrm{~Np}$ & $7.05 \mathrm{E}-4$ \\
\hline${ }^{239} \mathrm{Pu}$ & $6.22 \mathrm{E}-2$ \\
\hline${ }^{240} \mathrm{Pu}$ & $2.28 \mathrm{E}-1$ \\
\hline
\end{tabular}

Because of the complexity of many radionuclide analyses of high-level waste, separate method description summaries and data reports were issued by the ADS radiochemistry laboratory for each measurement. The following narratives discuss the methods used for measuring the radionuclide concentrations shown in Table 7-17. These narratives are intended to convey the general flow of the methods and do not include all the method details.

\subsubsection{Determinations of ${ }^{3} \mathrm{H}$ in AY-102/C-106 Solids Fraction}

Radiochemistry Reference: ADS Procedure 2444: "Tritium in Environmental Samples-A Distillation Procedure,” Issue date: 4/1/1999, Author: R.A. Sigg.

\section{Radiochemistry Narrative:}

Document Number: $\quad$ SRT-ADS-2002-01400

Date of Issue: $\quad$ 8/23/2002

Authors: $\quad$ C.C. DiPrete and D.P. DiPrete

\section{Discussion:}

An aliquot of each sample was steam-distilled to separate the tritium- containing fraction from the remainder of the sample. An aliquot of each distillate was added to liquid scintillation cocktail and analyzed for tritium. The samples were counted on a Packard Instruments liquid scintillation counter along with an instrument blank. The instrument blank was counted first and was used to establish an instrument background that was subtracted from the count results for the samples.

Results that are preceded by " $<$ " are either less than the minimum detectable activity (mda) for the method used or qualified as upper limits due to some spectral interference indicating an incomplete separation of tritium from remaining nuclides. All results, even upper limits, are below the MRQ when cell dilution is accounted for with the exception of the serial dilution, which slightly exceeded the MRQ. 


\subsubsection{Determinations of ${ }^{14} \mathrm{C}$ in $\mathrm{AY}-102 / \mathrm{C}-106$ Solids Fraction}

Radiochemistry Reference: ADS Procedure 2424: “Gross Alpha/Beta Determination by Liquid Scintillation Counting," Issue date: 2/28/1999, Authors: J.D. Leyba and D.P. DiPrete.

\section{Radiochemistry Narrative:}

Document Number: SRT-ADS-2003-01022

Date of Issue: $\quad$ 1/16/2003

Authors: $\quad$ C.C. DiPrete and D.P. DiPrete

\section{Discussion:}

The Analytical Development Section measured ${ }^{14} \mathrm{C}$ on the AY-102 solid fraction. AY-102 solids were submitted in pre-weighed centrifuge tubes, two tubes for each of the triplicate trials, with an extra pair for the matrix spike sample. The high activity of the samples precluded use of the routine ${ }^{14} \mathrm{C}$ method. The method was adjusted to enhance the separation of ${ }^{14} \mathrm{C}$ beta activity from the other activity. The sub-samples were wet-ashed with a sodium persulfate/silver nitrate oxidation in conjunction with concentrated sulfuric acid. The carbon dioxide emitted was absorbed with $3 \mathrm{M} \mathrm{NaOH}$ over a period of 3 days. The $3 \mathrm{M} \mathrm{NaOH}$ was then acidified, liberating the carbon dioxide, which was re-absorbed with Packard Instruments Carbosorb E over a period of 2 days. The Carbosorb E was then slurried into Ultima Gold $\mathrm{AB}$, and analyzed by liquid scintillation analysis for ${ }^{14} \mathrm{C}$. A laboratory control blank solution, spiked with a ${ }^{14} \mathrm{C}$ standard, was run in duplicate, in parallel with the samples to determine ${ }^{14} \mathrm{C}$ recoveries, the average of which were applied to the sample ${ }^{14} \mathrm{C}$ LSC results to quantify the ${ }^{14} \mathrm{C}$ concentrations in the samples. One AY-102 sample was spiked with ${ }^{14} \mathrm{C}$ (again in duplicate) and run through the process to serve as the matrix spike. A second laboratory control blank solution, spiked with a ${ }^{14} \mathrm{C}$ standard, was run through the process in duplicate to serve as the LCS sample. 


\subsubsection{Determinations of ${ }^{59 / 63} \mathrm{Ni}$ in $\mathrm{AY}-102 / \mathrm{C}-106$ Solids Fraction}

Radiochemistry Reference: ADS Procedure 2424: “Gross Alpha/Beta Determination by Liquid Scintillation Counting," Issue date: 2/28/1999, Authors: J.D. Leyba and D.P. DiPrete.

\section{Radiochemistry Narrative:}

Document Number: SRT-ADS-2003-01269

Date of Issue: $\quad$ 5/16/2003

Authors: $\quad$ D.P. DiPrete

\section{Discussion:}

The Analytical Development Section (ADS) of SRTC conducted a second set of ${ }^{59} \mathrm{Ni}$ and ${ }^{63} \mathrm{Ni}$ analyses on a set of AY-102 as received sludge samples to improve the detection limits versus the initial measurements. The nickel in concentrated aliquots of aqua regia digested sample was extracted in the SRTC High Activity Cells using dimethylglyoxime (DMG). The extracted nickel solutions were removed from the cells, and a repeat DMG extraction was carried out in ADS radiohoods. Aliquots of the resulting separated nickel solution were analyzed by liquid scintillation to determine ${ }^{63} \mathrm{Ni}$, x-ray spectroscopy to determine ${ }^{59} \mathrm{Ni}$, and ICP-ES to determine the concentrations of nickel recovered. The concentrations of nickel recovered were ratioed to the activities of ${ }^{59} \mathrm{Ni}$ and ${ }^{63} \mathrm{Ni}$ measured. Those ratios are provided below, as well as quantified ${ }^{59} \mathrm{Ni}$ and ${ }^{63} \mathrm{Ni}$ activities per kilogram of dried sludge using the measured stable nickel concentrations in the sludge. A cell control blank was used to check for cross-contamination.

\section{RESULTS \\ Sample ID dpm Ni-59/mg Ni 1 Sigma \%Unc dpm Ni-63/mg Ni 1Sigma \%Unc 181739 mda $6.22 \mathrm{E}+03$ $10.59 \%$ \\ 181742 \\ 181743 \\ $3.34 \mathrm{E}+04$ \\ $8.87 \%$ \\ $2.86 \mathrm{E}+06$ \\ $8.25 \%$ \\ 181744 \\ $2.97 \mathrm{E}+04$ \\ $9.41 \%$ \\ $2.98 \mathrm{E}+06$ \\ $8.29 \%$ \\ $9.40 \%$ \\ $3.97 \mathrm{E}+06$ \\ $8.31 \%$}

Using the average stable nickel concentration of $4,770 \mathrm{mg} / \mathrm{kg}$ dry sludge from the aqua regia digestions, the results above convert to the following activities per gram of dried sludge. 


$\begin{array}{ccccc}\text { Sample ID } & \begin{array}{c}\text { Ni-59 dpm/kg } \\ \text { sludge }\end{array} & \text { 1 Sigma \%Unc } & \begin{array}{c}\text { Ni-63 dpm/kg } \\ \text { sludge }\end{array} & \text { 1 Sigma \%Unc } \\ 181739 & 2.64 \mathrm{E}+06 & \text { mda } & 2.97 \mathrm{E}+07 & 10.59 \% \\ 181742 & 1.59 \mathrm{E}+08 & 8.87 \% & 1.36 \mathrm{E}+10 & 8.25 \% \\ 181743 & 1.42 \mathrm{E}+08 & 9.41 \% & 1.42 \mathrm{E}+10 & 8.29 \% \\ 181744 & 2.05 \mathrm{E}+08 & 9.40 \% & 1.89 \mathrm{E}+10 & 8.31 \%\end{array}$

$\begin{array}{ccccc}\text { Sample ID } & \begin{array}{c}\text { Ni-59 mCi/kg } \\ \text { sludge }\end{array} & \text { 1 Sigma \%Unc } & \begin{array}{c}\text { Ni-63 mCi/kg } \\ \text { sludge }\end{array} & \text { 1 Sigma \%Unc } \\ 181739 & <1.19 \mathrm{E}-03 & \text { mda } & 1.34 \mathrm{E}-02 & 10.59 \% \\ 181742 & 7.17 \mathrm{E}-02 & 8.87 \% & 6.14 \mathrm{E}+00 & 8.25 \% \\ 181743 & 6.39 \mathrm{E}-02 & 9.41 \% & 6.41 \mathrm{E}+00 & 8.29 \% \\ 181744 & 9.25 \mathrm{E}-02 & 9.40 \% & 8.53 \mathrm{E}+00 & 8.31 \%\end{array}$

\subsubsection{Determinations of ${ }^{60} \mathrm{Co}$ in $\mathrm{AY}-102 / \mathrm{C}-106$ Solids Fraction}

Radiochemistry Reference: ADS Procedure 2420: "Gamma Sample Preparation and Analysis,” Issue date: 3/31/2002, Author: C.C. DiPrete.

\section{Radiochemistry Narrative:}

Document Number: SRT-ADS-2002-01014

Date of Issue: $\quad$ 1/14/2003

Authors: $\quad$ C.C. DiPrete and D.P. DiPrete

\section{Discussion:}

The Analytical Development Section performed extended counting time gamma pulse height analyses on AY-102 solid fraction digested by hot aqua regia. A sample aliquot was treated with additional nitric acid and the ${ }^{137} \mathrm{Cs}$ level was reduced by 2 addition/filtration treatment steps with Bio-Rad AMP-1 resin. The sample was then subsequently analyzed by gamma spectroscopy using a high purity germanium detector for at least 8 hours. Results are background subtracted. 


\subsubsection{Determinations of ${ }^{79}$ Se in AY-102/C-106 Solids Fraction}

Radiochemistry Reference: ADS Procedure 2424: “Gross Alpha/Beta Determination by Liquid Scintillation Counting," Issue date: 2/28/1999, Authors: J.D. Leyba and D.P. DiPrete.

\section{Radiochemistry Narrative:}

Document Number: SRT-ADS-2003-01271

Date of Issue: $\quad$ 5/15/2003

Author: $\quad$ D.P. DiPrete

\section{Discussion:}

The Analytical Development Section performed analyses for ${ }^{79} \mathrm{Se}$ on AY-102 sludge digested by aqua regia. The samples had been analyzed previously and were re-analyzed to lower the MRQs. Aliquots of sample were spiked initially with stable Se which acted as both a chemical carrier and a Se yield tracer for the ${ }^{79}$ Se measurements in the SRTC high activity cells. The solutions were run through a decontamination procedure initially in the Cells. The decontaminated solutions were then transferred to ADS for a further cleanup in the radiohoods. Numerous decontamination steps were required to remove interfering radionuclides. The solutions were then reduced to precipitate Se metal. The Se metal was washed repeatedly, re-dissolved, and the solution was then decontaminated with several types of analytical resins. The decontaminated solutions were then concentrated. Aliquots of the concentrate were analyzed by neutron activation analysis to determine Se carrier yields, and by liquid scintillation to measure ${ }^{79}$ Se activities. High-energy beta was observed in the ${ }^{79} \mathrm{Se}$ spectra of these samples, so the results are must be reported conservatively as upper limits. 


\subsubsection{Determinations of ${ }^{90} \mathrm{Sr}$ in $\mathrm{AY}-102 / \mathrm{C}-106$ Solids Fraction}

Radiochemistry Reference: ADS Procedure 2447: "Sr-90 in Environmental Samples," Issue date: 3/31/1998, Author: D.P. DiPrete.

\section{Radiochemistry Narrative:}

Document Number: SRT-ADS-2002-01537

Date of Issue: $\quad 11 / 18 / 2002$

Authors: $\quad$ C.C. DiPrete and D.P. DiPrete

\section{Discussion:}

The Analytical Development Section performed Sr separations and analyses on AY-102 solids fraction following a hot aqua regia digestion. Sample aliquots were analyzed for ${ }^{90} \mathrm{Sr}$ using an Eichrom Sr-Spec based extraction procedure. Two ${ }^{90} \mathrm{Sr}$ spiked blanks, a serial dilution, and a ${ }^{90} \mathrm{Sr}$ spiked sample were analyzed with the sample batch to establish ${ }^{90} \mathrm{Sr} /{ }^{90} \mathrm{Y}$ batch QA. The QA samples were treated exactly like the analytical samples. Once the extractions were complete, aliquots of the resultant ${ }^{90} \mathrm{Sr} /{ }^{90} \mathrm{Y}$-containing extracts mixed with liquid scintillation cocktail were counted in the ADS Radiochemistry Counting Facility. The samples were counted on a Packard Instruments liquid scintillation counter along with an instrument blank. The instrument blank was counted first and was used to establish an instrument background that was subtracted from the count results for the samples. Uncertainties provided, which are based primarily on counting statistics, are 1 sigma. Aliquots of the ${ }^{90} \mathrm{Sr} /{ }^{90} \mathrm{Y}$-containing extracts were also analyzed by neutron activation analysis using the SRTC ${ }^{252}$ Cf Neutron Activation Analysis Facility in order to yield each sample separation. 


\subsubsection{Determinations of ${ }^{99} \mathrm{Tc}$ (Total) in AY-102/C-106 Solids Fraction}

Radiochemistry Reference: ADS Procedure 2445: “999 Tc by Extraction Chromatography,” Issue date: 2/14/1999, Author: R.A. Sigg.

\section{Radiochemistry Narrative:}

Document Number: SRT-ADS-2003-01053

Date of Issue: $\quad 1 / 27 / 2003$

Authors: $\quad$ C.C. DiPrete and D.P. DiPrete

\section{Discussion:}

The Analytical Development Section performed ${ }^{99} \mathrm{Tc}$ (total) separations and analyses on AY-102 solid fraction after aqua regia digestions. ${ }^{99 \mathrm{~m}} \mathrm{Tc}$ tracers were generated initially by neutron irradiation of natural molybdenum using the SRTC ${ }^{252} \mathrm{Cf}$ Neutron Activation Analysis facility. ${ }^{98}$ Mo was activated to ${ }^{99}$ Mo that subsequently beta decayed to ${ }^{99 \mathrm{~m}} \mathrm{Tc}$ that was then extracted from the ${ }^{99} \mathrm{Mo}$, and oxidized to form a ${ }^{99 \mathrm{~m}} \mathrm{Tc}$ pertechnetate tracer. Aliquots of sample were spiked with ${ }^{99 \mathrm{~m}} \mathrm{Tc}$ tracer that was subsequently extracted using an Aliquat 336 (Eichrom TEVA) based extraction. Aliquat 336 extracts ${ }^{99} \mathrm{Tc}$ in the pertechnetate form. The hot aqua regia dissolution procedure carried out in pressurized vessels oxidizes all Tc present to the pertechnetate form. Aliquots of the extractants were analyzed by gamma spectroscopy to determine ${ }^{99 \mathrm{~m}} \mathrm{Tc}$ tracer recoveries. Aliquots were also analyzed by liquid scintillation analysis to determine ${ }^{99} \mathrm{Tc}$ activities. ${ }^{99 \mathrm{~m}} \mathrm{Tc}$ tracer recoveries were applied to the liquid scintillation results to quantify the ${ }^{99} \mathrm{Tc}$. A blank solution was also analyzed along with the sample batch to ensure no contamination was evident at the laboratory level. A blank spiked with ${ }^{99} \mathrm{Tc}$ was also analyzed. The \% RSD is large, but the liquid scintillation spectra appeared to have some interfering nuclides present indicating imperfect separations Therefore, results are reported as upper limits. 


\subsubsection{Determinations of ${ }^{125} \mathrm{Sb},{ }^{126} \mathrm{Sb}-{ }^{126} \mathrm{Sn}$ in $\mathrm{AY}-102 / \mathrm{C}-106$ Solids Fraction}

Radiochemistry Reference: ADS Procedure 2420: "Gamma Sample Preparation and Analysis," Issue date: 3/31/2002, Author: C.C. DiPrete.

\section{Radiochemistry Narrative:}

Document Number: SRT-ADS-2003-01014

Date of Issue: $\quad$ 1/14/2003

Authors: $\quad$ C.C. DiPrete and D.P. DiPrete

\section{Discussion:}

The Analytical Development Section performed extended counting time gamma pulse height analyses on the AY-102 solid fraction digested by acid. A sample aliquot was treated with additional nitric acid and ${ }^{137} \mathrm{Cs}$ levels were reduced by 2 addition/filtration treatments with Bio-Rad AMP-1 resin. The samples were then subsequently analyzed by gamma spectroscopy analysis using a high purity germanium detector for at least 8 hours. The gamma spectroscopy analysis uncertainties provided, which are based primarily on counting statistics, are 1 sigma. Results are background subtracted.

\subsubsection{Determinations of ${ }^{129} \mathrm{I}$ in AY-102/C-106 Solids Fraction}

Radiochemistry Reference: ADS Procedure 2420: "Gamma Sample Preparation and Analysis," Issue date: 3/31/2002, Author: C.C. DiPrete.

\section{Radiochemistry Narrative:}

Document Number: SRT-ADS-2002-01541

Date of Issue: $\quad$ 11/18/2002

Authors: $\quad$ C.C. DiPrete and D.P. DiPrete

\section{Discussion:}

The Analytical Development Section performed ${ }^{129}$ I determinations on AY-102 solid fraction samples. Sludge aliquots were spiked with a KI carrier in the SRTC Shielded Cells, and then were digested in pressurized vessels using hot aqua regia. Each digestion vessel contained a quantity of dilute $\mathrm{NaOH}$ in an enclosed vial to absorb iodine vapor as it was liberated. The caustic solutions were subsequently removed from the shielded cells and a silver iodide precipitation was performed to enhance the separation of iodide. A blank DI water sample was analyzed along with the batch. The precipitates were analyzed for ${ }^{129}$ I activity with a low-energy HPGe gamma spectroscopy detector. After the gamma analyses, the precipitates were analyzed by neutron activation analysis to determine the levels of stable iodide carrier in the precipitates. The recoveries of the iodide carrier were used to correct the gamma spectroscopy results for the ${ }^{129}$ I recoveries. Uncertainties provided are 1 sigma. 


\subsubsection{Determinations of ${ }^{137} \mathrm{Cs}$ in $\mathrm{AY}-102 / \mathrm{C}-106$ Solids Fraction}

Radiochemistry Reference: ADS Procedure 2420: "Gamma Sample Preparation and Analysis," Issue date: 3/31/2002, Author: C.C. DiPrete.

\section{Radiochemistry Narrative:}

Document Number: $\quad$ SRT-ADS-2002-01538

Date of Issue: $\quad$ 11/15/2002

Authors: $\quad$ C.C. DiPrete and D.P. DiPrete

\section{Discussion:}

The Analytical Development Section performed gamma pulse height analyses on AY-102 solid fraction samples after aqua regia digestions. An aliquot of each sample was analyzed by gamma spectroscopy using a high purity germanium detector. The gamma spectroscopy analysis uncertainties provided, which are based primarily on counting statistics, are 1 sigma. Results are background subtracted.

\subsubsection{Determinations of ${ }^{151} \mathrm{Sm}$ in AY-102/C-106 Solids Fraction}

Radiochemistry Reference: ADS Procedure 2424: "Gross Alpha/Beta Determination by Liquid Scintillation Counting," Issue date: 2/28/1999, Authors: J.D. Leyba and D.P. DiPrete.

\section{Radiochemistry Narrative:}

Document Number: SRT-ADS-2003-01571

Date of Issue: $\quad$ 9/23/2003

Authors: $\quad$ C.C. DiPrete and D.P. DiPrete

\section{Discussion:}

The Analytical Development Section performed ${ }^{151} \mathrm{Sm}$ determinations on the AY-102 solid fraction following digestion with the $\mathrm{KOH} / \mathrm{KNO}_{3}$ fusion technique. The measurements were based on a Sm extraction followed by a liquid scintillation analysis for the ${ }^{151} \mathrm{Sm}$ beta, and a neutron activation analysis to determine Sm carrier recoveries. Aliquots of digested solids were spiked with a stable Sm carrier, the solutions were oxidized, evaporated to dryness, and re-dissolved in dilute nitric acid. The ${ }^{151} \mathrm{Sm}$ was extracted using a di(2-ethylhexyl)

orthophosphoric acid (HDEHP) based extraction. The ${ }^{151} \mathrm{Sm}$ beta liquid scintillation results were quantified using the comparable beta energy isotope ${ }^{63} \mathrm{Ni}$ LSC quench curve. The Sm carrier recoveries were determined using neutron activation analysis, and applied to the liquid scintillation results to correct for separation losses. The triplicate sample results had a $\%$ RSD of about $7 \%$. The sample solutions were high in ${ }^{151} \mathrm{Sm}$, (roughly $50 \%$ more ${ }^{151} \mathrm{Sm}$ activity than the ${ }^{151} \mathrm{Sm}$ added to the matrix spike sample), thus increasing the uncertainty of the matrix spike recovery calculation. 


\subsubsection{Determinations of ${ }^{152} \mathrm{Eu},{ }^{154} \mathrm{Eu},{ }^{155} \mathrm{Eu},{ }^{231} \mathrm{~Pa}$ in $\mathrm{AY}-102 / \mathrm{C}-106$ Solids Fraction}

Radiochemistry Reference: ADS Procedure 2420: "Gamma Sample Preparation and Analysis," Issue date: 3/31/2002, Author: C.C. DiPrete.

\section{Radiochemistry Narrative:}

Document Number: $\quad$ SRT-ADS-2002-01014

Date of Issue: $\quad$ 1/14/2003

Authors: $\quad$ C.C. DiPrete and D.P. DiPrete

\section{Discussion:}

The Analytical Development Section performed extended counting time gamma pulse height analyses on AY-102 solid fraction samples digested with aqua regia. The ${ }^{137} \mathrm{Cs}$ was first stripped to permit gamma analysis of the low-level gamma emitters. A sample aliquot was treated with additional nitric acid and ${ }^{137} \mathrm{Cs}$ levels were reduced by 2 addition/filtration treatments with Bio-Rad AMP-1 resin. The samples were then subsequently analyzed by gamma spectroscopy analysis using a high purity germanium detector for at least 8 hours. The gamma spectroscopy analysis uncertainties provided, which are based primarily on counting statistics, are 1 sigma. Results are background subtracted. 


\subsubsection{Determinations of ${ }^{238} \mathrm{Pu},{ }^{239-240} \mathrm{Pu},{ }^{241} \mathrm{Pu}$ in $\mathrm{AY}-102 / \mathrm{C}-106$ Solids Fraction}

Radiochemistry Reference: ADS Procedure 2453: "Plutonium TTA Extraction and Alpha Analysis," Issue date: 9/28/1998, Author: D.P. DiPrete.

\section{Radiochemistry Narrative:}

Document Number: SRT-ADS-2002-01570

Date of Issue: $\quad 12 / 4 / 2002$

Authors: $\quad$ C.C. DiPrete and D.P. DiPrete

\section{Discussion:}

The Analytical Development Section performed plutonium separations and analyses on AY102 solid fraction after hot aqua regia digestions. Sample aliquots were treated with a thenoyltrifluoroacetone (TTA) to separate $\mathrm{Pu}$ from interfering radionuclides. An aliquot was initially spiked with ${ }^{238} \mathrm{Pu}$ tracer. A second aliquot of straight sample dissolution was analyzed along with the spiked sample. In addition, a third aliquot was used for determining the ${ }^{241} \mathrm{Pu}$ concentration. All of the plutonium in the samples was reduced using hydroxylamine. An anion complexing reagent (aluminum nitrate) was then added, and the solutions were oxidized with $4 \mathrm{M}$ sodium nitrite. The plutonium was then extracted from the matrix using a TTA solution. The TTA layer was mounted on a counting dish, the mount was then analyzed by alpha spectroscopy. A blank sample was run with the sample set.

The ${ }^{239 / 240} \mathrm{Pu}$ alpha peaks were yielded using the ${ }^{238} \mathrm{Pu}$ recoveries from the ${ }^{238} \mathrm{Pu}$ traced sample separation. The ratio of the ${ }^{239 / 240} \mathrm{Pu}$ to the ${ }^{238} \mathrm{Pu}$ in the sample was obtained from the alpha spectroscopy analysis of the non-spiked sample. That ratio was applied to the determined ${ }^{239 / 240} \mathrm{Pu}$ value to determine the ${ }^{238} \mathrm{Pu}$ activity in the sample.

The sample aliquot dedicated to the ${ }^{241} \mathrm{Pu}$ analysis was added to liquid scintillation cocktail following the separation and analyzed for both ${ }^{241} \mathrm{Pu}$ and total $\mathrm{Pu}$-alpha constituents. The ratio of ${ }^{241} \mathrm{Pu}$ to total $\mathrm{Pu}$ alpha was determined and applied to the results from the plates in order to determine a ${ }^{241} \mathrm{Pu}$ concentration. The uncertainties provided are 1 sigma. 


\subsubsection{Determinations of ${ }^{241} \mathrm{Am},{ }^{243} \mathrm{Am},{ }^{242} \mathrm{Cm},{ }^{243 / 244} \mathrm{Cm}$ in AY-102/C-106 Solids Fraction}

Radiochemistry Reference: ADS Procedure 2449: "Actinides in Environmental Samples," Issue date: 9/28/1998; Author: D.P. DiPrete.

\section{Radiochemistry Narrative:}

Document Number: $\quad$ SRT-ADS-2003-01070

Date of Issue: $\quad$ 1/31/2003

Authors: $\quad$ C.C. DiPrete and D.P. DiPrete

\section{Discussion:}

The Analytical Development Section performed ${ }^{241} \mathrm{Am},{ }^{243} \mathrm{Am},{ }^{244} \mathrm{Cm}$ and ${ }^{242} \mathrm{Cm}$ determinations on AY-102 solid fraction after hot aqua regia digestions. Aliquots of sample were run through the $\mathrm{Am} / \mathrm{Cm}$ separation procedure to separate the trivalent $\mathrm{Am} / \mathrm{Cm}$ isotopes from the higher valence state actinides following a sample oxidation step. Samples were run through the procedure in duplicate, one sample spiked with ${ }^{243} \mathrm{Am}$ for yielding purposes, one sample with no spike to correct for any ${ }^{243} \mathrm{Am}$ present in the samples. The Am/Cm sample mount was analyzed by alpha for ${ }^{244} \mathrm{Cm}$ and ${ }^{242} \mathrm{Cm}$ and by low energy gamma spectrometry for ${ }^{241} \mathrm{Am}$. The gamma results were yielded by using the ${ }^{243} \mathrm{Am}$ tracer gamma result to quantify the ${ }^{241} \mathrm{Am}$ activity in the samples. The ${ }^{241} \mathrm{Am}$ activity in the samples was high enough to swamp out the ${ }^{243} \mathrm{Am}$ spikes in the alpha spectrum. Therefore, alpha results of ${ }^{244} \mathrm{Cm}$ and ${ }^{242} \mathrm{Cm}$ were quantified by taking a ratio of their alpha peaks to that of the ${ }^{241} \mathrm{Am}$ previously quantified in the gamma measurement. ${ }^{243} \mathrm{Am}$ values were quantified off a low energy gamma analysis of the mount containing no ${ }^{243} \mathrm{Am}$ spike, and was quantified using the ${ }^{243} \mathrm{Am} /{ }^{241} \mathrm{Am}$ ratio applied to the quantified ${ }^{241} \mathrm{Am}$ activity. A laboratory blank sample was run through all of the analyses with the batch of samples. 


\subsubsection{Total Beta Determinations of the AY-102/C-106 Solids Fraction}

Radiochemistry Reference: ADS Procedure 2424: "Gross Alpha/Beta Determination by Liquid Scintillation Counting," Issue date: 2/28/1999, Authors: J.D. Leyba and D.P. DiPrete.

\section{Radiochemistry Narrative:}

Document Number: SRT-ADS-2003-01577

Date of Issue: $\quad$ 12/7/2003

Authors: $\quad$ C.C. DiPrete and D.P. DiPrete

\section{Discussion:}

Diluted aliquots of the samples were added to liquid scintillation cocktail. In order to monitor and correct for any alpha/beta spill-over events, an identical samples spiked with alpha activity was analyzed in sequence with each unspiked sample. The samples were counted on a Packard Instruments liquid scintillation counter along with an instrument blank. The instrument blank was counted first and was used to establish an instrument background that was subtracted from the count results for the samples. Analysis uncertainties provided, which are based primarily on counting statistics, are 1 sigma. Note that the matrix spike recovery was $82 \%$, but that this recovery falls within the Task and QA Plan limits of 70-30\%.

\subsubsection{Total Alpha Determinations of the AY-102/C-106 Solids Fraction}

Radiochemistry Reference: ADS Procedure 2402: “Alpha Pulse Height Analysis,” Issue date: 12/31/2000, Author: J.D. Leyba

\section{Radiochemistry Narrative:}

Document Number: $\quad$ SRT-ADS-2003-01086

Date of Issue: $\quad$ 2/7/2003

Authors: $\quad$ C.C. DiPrete and D.P. DiPrete

\section{Discussion:}

The Analytical Development Section performed total alpha analyses on AY-102 solid fraction after aqua regia dissolution. Prior to the analyses, ${ }^{137} \mathrm{Cs}$ was removed from aliquots of the samples in order to reduce bias caused by large beta/alpha ratios. This was accomplished using Bio-Rad AMP1 resin. Following the Cs removal process, aliquots of the Cs-stripped samples were mounted on stainless steel counting planchets and analyzed for alpha activity using a gas-flow proportional counter. Results are background subtracted.

The total alpha determinations exceed the sum of transuranic isotopes by approximately a factor of nine. The total alpha determinations are biased high from inadequate separation of ${ }^{90} \mathrm{Sr}$ prior to alpha counting. 


\subsubsection{Sum of Transuranic Isotopic Measurements in AY-102/C-106 Solid Fraction}

The alpha-emitting transuranic (TRU) isotopes were summed from the individual measurements of ${ }^{238} \mathrm{Pu},{ }^{239} \mathrm{Pu},{ }^{237} \mathrm{~Np},{ }^{240-241} \mathrm{Pu},{ }^{241} \mathrm{Am},{ }^{243} \mathrm{Am},{ }^{242} \mathrm{Cm}$, and ${ }^{243 / 244} \mathrm{Cm}$. The sum of the individual TRU isotope measurements was about a factor of nine lower than the total alpha measurements $(7.0 \mathrm{E}+1 \mathrm{mCi} / \mathrm{kg}$ total alpha vs. $7.7 \mathrm{E} 0 \mathrm{mCi} / \mathrm{kg}$ sum of TRU isotopes). The discrepancy is caused by a high bias in the total alpha analysis from imperfect separation of the high levels of ${ }^{90} \mathrm{Sr}$ in the solid fraction prior to the plate making.

The contribution of ${ }^{243 / 244} \mathrm{Cm}$ to the sum of TRU is suspect because the ${ }^{244} \mathrm{Cm}$ level in the blank analysis was about $5 \%$ of the total TRU. Therefore, the TRU values are probably biased at least $5 \%$ high from the ${ }^{244} \mathrm{Cm}$ contribution due to cross-contamination introduced in the shielded cell sample preparation. 
Table 7-17. Radionuclide Composition of AY-102/C-106 Solids Fraction

Concentrations are on wet solids basis after centrifugation.

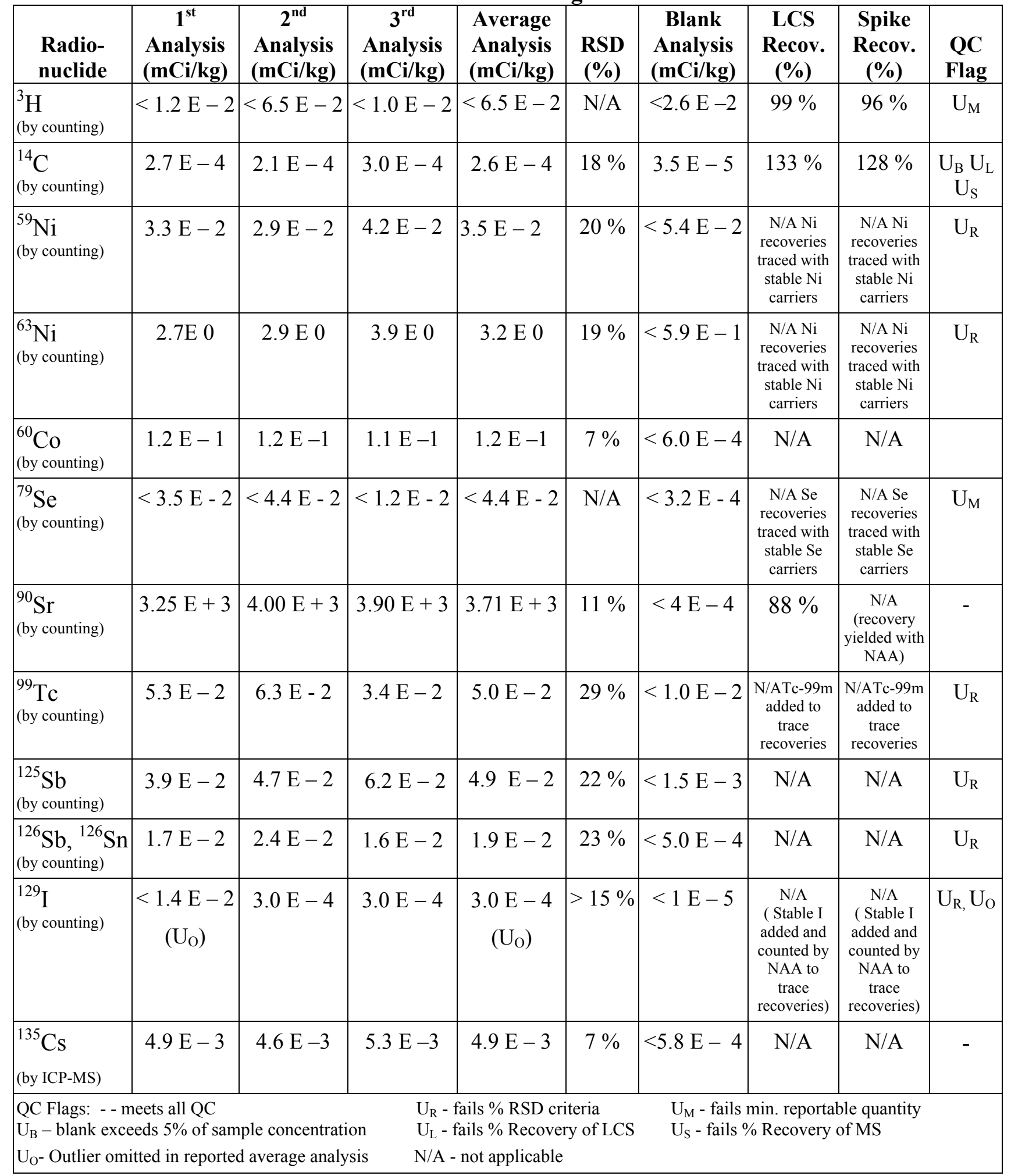


WSRC-TR-2003-00205, REVISION 0

SRT-RPP-2003-00086, REVISION 0

Table 7-17. Radionuclide Composition of AY-102/C-106 Solids Fraction - page 2 of 3

Concentrations are on wet solids basis after centrifugation.

\begin{tabular}{|c|c|c|c|c|c|c|c|c|c|}
\hline $\begin{array}{l}\text { Radio- } \\
\text { nuclide }\end{array}$ & $\begin{array}{c}1^{\text {st }} \\
\text { Analysis } \\
(\mathrm{mCi} / \mathrm{kg})\end{array}$ & $\begin{array}{c}2^{\text {nd }} \\
\text { Analysis } \\
\text { (mCi/kg) }\end{array}$ & $\begin{array}{c}3^{\text {rd }} \\
\text { Analysis } \\
\text { (mCi/kg) }\end{array}$ & $\begin{array}{l}\text { Average } \\
\text { Analysis } \\
(\mathrm{mCi} / \mathrm{kg})\end{array}$ & $\begin{array}{l}\text { RSD } \\
(\%)\end{array}$ & $\begin{array}{c}\text { Blank } \\
\text { Analysis } \\
\text { (mCi/kg) } \\
\end{array}$ & $\begin{array}{c}\text { LCS } \\
\text { Recov. } \\
(\%)\end{array}$ & $\begin{array}{c}\text { Spike } \\
\text { Recov. } \\
(\%)\end{array}$ & $\begin{array}{l}\text { QC } \\
\text { Flag }\end{array}$ \\
\hline $\begin{array}{l}{ }^{137} \mathrm{Cs} \\
\text { (by counting) }\end{array}$ & $2.33 E+2$ & $2.59 E+2$ & $2.51 \mathrm{E}+2$ & $2.48 \mathrm{E}+2$ & $5 \%$ & $<2 \mathrm{E}-4$ & N/A & N/A & - \\
\hline $\begin{array}{l}{ }^{151} \mathrm{Sm} \\
\text { (by counting) }\end{array}$ & $1.01 \mathrm{E}+2$ & $1.03 E+2$ & $1.14 \mathrm{E}+2$ & $1.06 \mathrm{E}+2$ & $7 \%$ & $2.94 \mathrm{E}-1$ & $100 \%$ & $120 \%$ & $\mathrm{U}_{\mathrm{S}}$ \\
\hline $\begin{array}{l}{ }^{152} \mathrm{Eu} \\
\text { (by counting) }\end{array}$ & $9.6 E-2$ & $9.9 E-2$ & $9.1 \mathrm{E}-2$ & $9.5 E-2$ & $4 \%$ & $<5.0 \mathrm{E}-3$ & N/A & N/A & - \\
\hline $\begin{array}{l}{ }^{154} \mathrm{Eu} \\
\text { (by counting) }\end{array}$ & $2.1 \mathrm{E} 0$ & $2.2 \mathrm{E} 0$ & $1.9 \mathrm{E} 0$ & $2.1 \mathrm{E} 0$ & $7 \%$ & $<7 \mathrm{E}-4$ & N/A & N/A & - \\
\hline $\begin{array}{l}{ }^{155} \mathrm{Eu} \\
\text { (by counting) }\end{array}$ & $1.1 \mathrm{E} 0$ & $1.1 \mathrm{E} 0$ & $1.0 \mathrm{E} 0$ & $1.1 \mathrm{E} 0$ & $7 \%$ & $1 E-3$ & N/A & N/A & - \\
\hline $\begin{array}{l}{ }^{231} \mathrm{~Pa} \\
\text { (by counting) }\end{array}$ & $<2.6 \mathrm{E}-1$ & $<2.5 \mathrm{E}-1$ & $<2.5 \mathrm{E}-1$ & $<2.6 \mathrm{E}-1$ & N/A & $<1.7 \mathrm{E}-2$ & N/A & N/A & - \\
\hline $\begin{array}{l}{ }^{233} \mathrm{U} \\
\text { (by ICP-MS) }\end{array}$ & $<1.9 \mathrm{E}-2$ & $<1.9 \mathrm{E}-2$ & $<1.9 \mathrm{E}-2$ & $<1.9 \mathrm{E}-2$ & $\mathrm{~N} / \mathrm{A}$ & $<1.9 \mathrm{E}-3$ & N/A & N/A & - \\
\hline $\begin{array}{l}{ }^{234} \mathrm{U} \\
\text { (by ICP-MS) }\end{array}$ & $<1.2 \mathrm{E}-2$ & $<1.2 \mathrm{E}-2$ & $<1.2 \mathrm{E}-2$ & $<1.2 \mathrm{E}-2$ & $\mathrm{~N} / \mathrm{A}$ & $<1.2 \mathrm{E}-3$ & N/A & N/A & - \\
\hline $\begin{array}{l}{ }^{235} \mathrm{U} \\
\text { (by ICP-MS) }\end{array}$ & $2.9 E-5$ & $4.1 \mathrm{E}-5$ & $4.0 \mathrm{E}-5$ & $3.7 E-5$ & $18 \%$ & $<4.3 \mathrm{E}-7$ & $102 \%$ & N/A & $\mathrm{U}_{\mathrm{R}}$ \\
\hline $\begin{array}{l}{ }^{236} \mathrm{U} \\
\text { (by ICP-MS) }\end{array}$ & $<1.0 \mathrm{E}-4$ & $<1.0 \mathrm{E}-4$ & $<1.0 \mathrm{E}-4$ & $<1.0 \mathrm{E}-4$ & $\mathrm{~N} / \mathrm{A}$ & $<1.0 \mathrm{E}-5$ & N/A & $\mathrm{N} / \mathrm{A}$ & - \\
\hline $\begin{array}{l}{ }^{238} \mathrm{U} \\
\text { (by ICP-MS) }\end{array}$ & $7.0 \mathrm{E}-4$ & $7.3 \mathrm{E}-4$ & $7.3 E-4$ & $7.2 \mathrm{E}-4$ & $2 \%$ & $<3.0 \mathrm{E}-7$ & $99 \%$ & $100 \%$ & - \\
\hline $\begin{array}{l}{ }^{237} \mathrm{~Np} \\
\text { (by ICP-MS) }\end{array}$ & $5.4 E-3$ & $5.7 E-3$ & $6.0 E-3$ & $5.7 \mathrm{E}-3$ & $5 \%$ & $<1.0 \mathrm{E}-4$ & N/A & $\mathrm{N} / \mathrm{A}$ & - \\
\hline $\begin{array}{l}{ }^{238} \mathrm{Pu} \\
\text { (by counting) }\end{array}$ & $1.9 \mathrm{E}-1$ & $1.7 \mathrm{E}-1$ & $2.7 \mathrm{E}-1$ & $2.1 \mathrm{E}-1$ & $25 \%$ & $<7 \mathrm{E}-6$ & $\begin{array}{c}\mathrm{N} / \mathrm{A}\left({ }^{238} \mathrm{Pu}\right. \\
\text { tracer used } \\
\text { to yield } \\
\text { recovery) }\end{array}$ & $\begin{array}{l}\mathrm{N} / \mathrm{A}\left({ }^{238} \mathrm{Pu}\right. \\
\text { tracer used } \\
\text { to yield } \\
\text { recovery) }\end{array}$ & $\mathrm{U}_{\mathrm{R}}$ \\
\hline $\begin{array}{l}{ }^{239 / 240} \mathrm{Pu} \\
\text { (by counting) }\end{array}$ & $1.2 \mathrm{E} 0$ & $1.1 \mathrm{E} 0$ & $1.7 \mathrm{E} 0$ & $1.4 \mathrm{E} 0$ & $24 \%$ & $<1.1 \mathrm{E}-2$ & $\begin{array}{c}\mathrm{N} / \mathrm{A}\left({ }^{238} \mathrm{Pu}\right. \\
\text { tracer used } \\
\text { to yield } \\
\text { recovery) }\end{array}$ & $\begin{array}{c}\mathrm{N} / \mathrm{A}\left({ }^{238} \mathrm{Pu}\right. \\
\text { tracer used } \\
\text { to yield } \\
\text { recovery) }\end{array}$ & $\mathrm{U}_{\mathrm{R}}$ \\
\hline $\begin{array}{l}{ }^{239} \mathrm{Pu} \\
\text { (by ICP-MS) }\end{array}$ & $7.5 E-1$ & $1.3 \mathrm{E} 0$ & $9.3 \mathrm{E}-1$ & $1.0 \mathrm{E} 0$ & $28 \%$ & $<1.2 \mathrm{E}-2$ & N/A & N/A & $\mathrm{U}_{\mathrm{R}}$ \\
\hline \multicolumn{10}{|c|}{$\begin{array}{lc}\text { QC Flags: - meets all QC } & U_{R} \text { - fails \% RSD cri } \\
U_{B} \text { - blank exceeds 5\% of sample concentration } & U_{L} \text { - fails \% Recover } \\
U_{O^{-}} \text {Outlier omitted in reported average analysis } & \text { N/A - not applicable } \\
\end{array}$} \\
\hline
\end{tabular}


Table 7-17. Radionuclide Composition of AY-102/C-106 Solids Fraction - page 3 of 3

Concentrations are on wet solids basis after centrifugation.

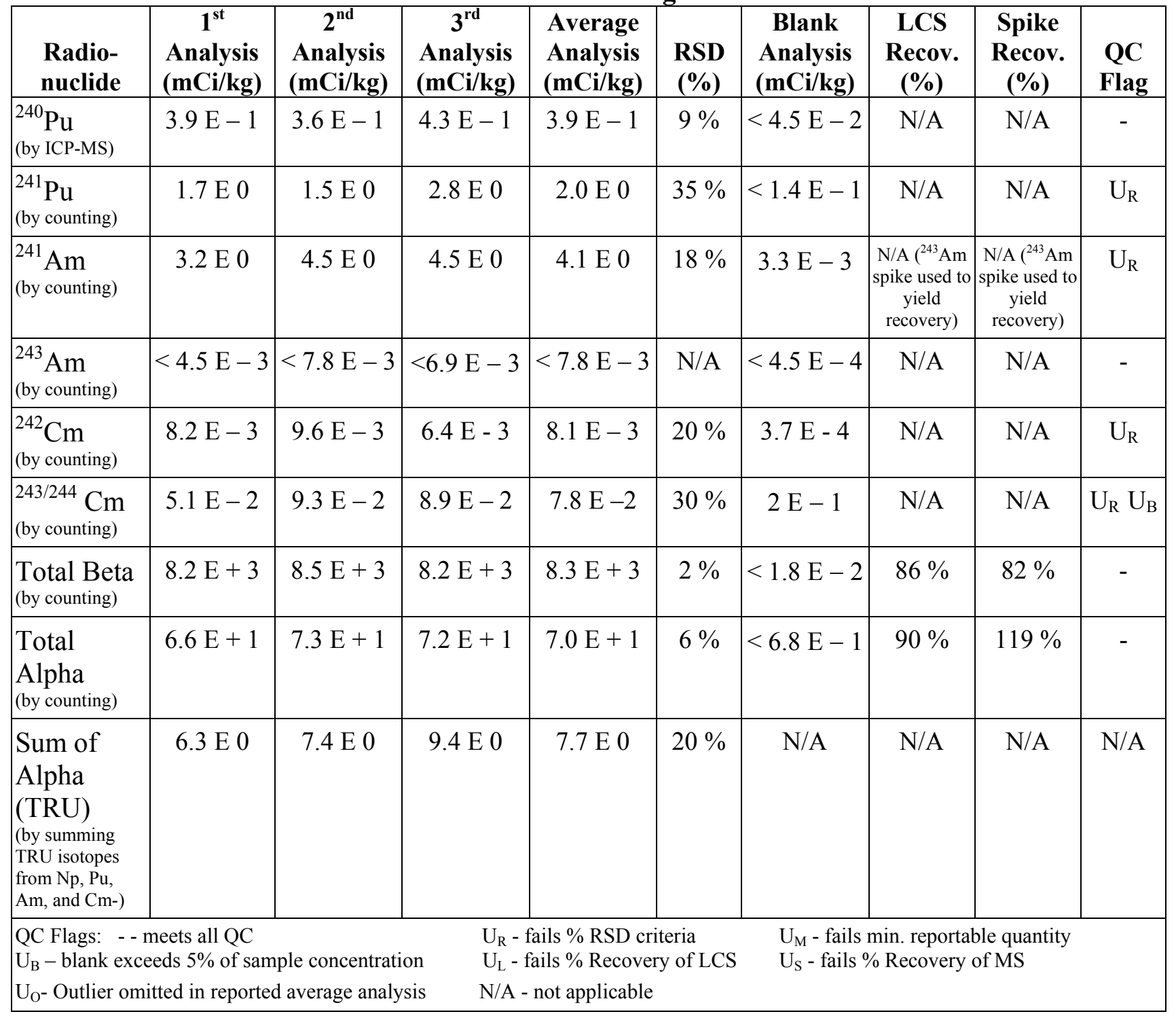

\subsection{RADIONUCLIDE COMPOSITION OF AY-102/C-106 SOLIDS ON BOTH WET SOLIDS FRACTION AND DRY SOLIDS BASIS}

As stipulated by the Test Specification, the composition of the solids fraction is to be reported on both a wet basis and a dry basis. The radionuclide measurements were performed on wet solids and the analytical results were reported on a wet solids basis. To convert the wet basis concentrations to dry basis concentrations, the weight \% dry solids in the wet solids fraction $(45.5 \%)$ was used to obtain the conversion factor of 2.2 that was used to multiply values. To facilitate comparison, both the wet solids basis concentrations and dry solids basis concentrations are included in Table 7-18. 
Table 7-18. Radionuclide Composition of AY-102/C-106 Solids Fraction on Both Wet Solids Basis and Dry Solids Basis

Wet to Dry Conversion Factor is 2.2

\begin{tabular}{|c|c|c|c|}
\hline Radionuclide & $\begin{array}{c}\text { Average Analysis on } \\
\text { Wet Solids Basis } \\
\text { (mCi/kg) }\end{array}$ & $\begin{array}{c}\text { Average Analysis on } \\
\text { Dry Solids Basis } \\
\text { (mCi/kg) }\end{array}$ & QC Flag \\
\hline (by counting) & $<6.5 \mathrm{E}-2$ & $<1.4 \mathrm{E}-1$ & $\mathrm{U}_{\mathrm{M}}$ \\
\hline (by counting) & $2.6 \mathrm{E}-4$ & $5.7 \mathrm{E}-4$ & $\mathrm{U}_{\mathrm{B}}, \mathrm{U}_{\mathrm{L}}, \mathrm{U}_{\mathrm{S}}$ \\
\hline${ }^{59} \mathrm{Ni} \quad$ (by counting) & $3.3 \mathrm{E}-2$ & $7.6 \mathrm{E}-2$ & $\mathrm{U}_{\mathrm{R}}$ \\
\hline${ }^{63} \mathrm{Ni} \quad$ (by counting) & $3.2 \mathrm{E} 0$ & $7.0 \mathrm{E}+0$ & $\mathrm{U}_{\mathrm{R}}$ \\
\hline${ }^{60} \mathrm{Co} \quad$ (by counting) & $1.2 \mathrm{E}-1$ & $2.6 \mathrm{E}-1$ & - \\
\hline${ }^{79} \mathrm{Se} \quad$ (by counting) & $<4.4 \mathrm{E}-2$ & $<9.7 \mathrm{E}-2$ & $\mathrm{U}_{\mathrm{M}}$ \\
\hline${ }^{90} \mathrm{Sr} \quad$ (by counting) & $3.71 \mathrm{E}+3$ & $8.16 \mathrm{E}+3$ & - \\
\hline${ }^{99} \mathrm{Tc} \quad$ (by counting) & $5.0 \mathrm{E}-2$ & $1.1 \mathrm{E}-1$ & $\mathrm{U}_{\mathrm{R}}$ \\
\hline${ }^{125} \mathrm{Sb} \quad$ (by counting) & $4.9 \mathrm{E}-2$ & $1.1 \mathrm{E}-1$ & $\mathrm{U}_{\mathrm{R}}$ \\
\hline${ }^{126} \mathrm{Sb},{ }^{126} \mathrm{Sn}$ (by counting) & $1.9 \mathrm{E}-2$ & $4.2 \mathrm{E}-2$ & $\mathrm{U}_{\mathrm{R}}$ \\
\hline (by counting) & $3.0 \mathrm{E}-4\left(\mathrm{U}_{\mathrm{O}}\right)$ & $6.6 \mathrm{E}-4\left(\mathrm{U}_{\mathrm{O}}\right)$ & $\mathrm{U}_{\mathrm{R}}, \mathrm{U}_{\mathrm{O}}$ \\
\hline${ }^{135} \mathrm{Cs} \quad$ (by ICP-MS) & $4.9 \mathrm{E}-3$ & $1.1 \mathrm{E}-2$ & - \\
\hline${ }^{137} \mathrm{Cs} \quad$ (by counting) & 2. $E+2$ & $5.46 \mathrm{E}+2$ & - \\
\hline${ }^{151} \mathrm{Sm} \quad$ (by counting) & $1.06 \mathrm{E}+2$ & $2.33 E+2$ & $\mathrm{U}_{\mathrm{S}}$ \\
\hline${ }^{152} \mathrm{Eu} \quad$ (by counting) & $9.5 \mathrm{E}-2$ & $2.1 \mathrm{E}-1$ & - \\
\hline${ }^{154} \mathrm{Eu} \quad$ (by counting) & $2.1 \mathrm{E} 0$ & $4.6 \mathrm{E} 0$ & - \\
\hline${ }^{155} \mathrm{Eu} \quad$ (by counting) & $1.1 \mathrm{E} 0$ & $2.4 \mathrm{E} 0$ & - \\
\hline${ }^{231} \mathrm{~Pa} \quad$ (by counting) & $<2.6 \mathrm{E}-1$ & $<5.7 \mathrm{E}-1$ & - \\
\hline (by ICP-MS) & $<1.9 \mathrm{E}-2$ & $<4.2 \mathrm{E}-2$ & - \\
\hline (by ICP-MS) & $<1.2 \mathrm{E}-2$ & $<2.6 \mathrm{E}-2$ & - \\
\hline (by ICP-MS) & $3.7 E-5$ & $8.1 \mathrm{E}-5$ & $\mathrm{U}_{\mathrm{R}}$ \\
\hline${ }^{236} \mathrm{U} \quad$ (by ICP-MS) & $<1.0 \mathrm{E}-4$ & $<2.2 \mathrm{E}-4$ & - \\
\hline \multicolumn{3}{|c|}{$\begin{array}{l}\text { QC Flags: - - meets all QC } \\
\mathrm{U}_{\mathrm{B}} \text { - blank exceeds } 5 \% \text { of sample concentration } \\
\mathrm{U}_{\mathrm{O}} \text { - Outlier omitted in reported average analysis }\end{array}$} & $\begin{array}{l}\text { ortable quantity } \\
\text { ery of MS }\end{array}$ \\
\hline
\end{tabular}


Table 7-18. Radionuclide Composition of AY-102/C-106 Solids Fraction on Both Wet Solids Basis and Dry Solids Basis - page 2 of 2

Wet to Dry Conversion Factor is 2.2

\begin{tabular}{|c|c|c|c|}
\hline Radionuclide & $\begin{array}{c}\text { Average Analysis on } \\
\text { Wet Solids Basis } \\
\text { (mCi/kg) }\end{array}$ & $\begin{array}{c}\text { Average Analysis on } \\
\text { Dry Solids Basis } \\
\text { (mCi/kg) }\end{array}$ & QC Flag \\
\hline${ }^{238} \mathrm{U} \quad$ (by ICP-MS) & $7.2 \mathrm{E}-4$ & $1.6 \mathrm{E}-3$ & - \\
\hline${ }^{237} \mathrm{~Np} \quad$ (by ICP-MS) & $5.7 \mathrm{E}-3$ & $1.3 \mathrm{E}-2$ & - \\
\hline${ }^{238} \mathrm{Pu} \quad$ (by counting) & $2.1 \mathrm{E}-1$ & $4.6 \mathrm{E}-1$ & $\mathrm{U}_{\mathrm{R}}$ \\
\hline${ }^{239 / 240} \mathrm{Pu}$ (by counting) & $1.4 \mathrm{E} 0$ & $3.1 \mathrm{E} 0$ & $\mathrm{U}_{\mathrm{R}}$ \\
\hline${ }^{239} \mathrm{Pu} \quad$ (by ICP-MS) & $1.0 \mathrm{E} 0$ & $2.2 \mathrm{E} 0$ & $\mathrm{U}_{\mathrm{R}}$ \\
\hline${ }^{240} \mathrm{Pu} \quad$ (by ICP-MS) & $3.9 \mathrm{E}-1$ & $8.6 \mathrm{E}-1$ & - \\
\hline${ }^{241} \mathrm{Pu} \quad$ (by counting) & $2.0 \mathrm{E} 0$ & $4.4 \mathrm{E} 0$ & $\mathrm{U}_{\mathrm{R}}$ \\
\hline${ }^{241}$ Am (by counting) & $4.1 \mathrm{E} 0$ & 9.0 E 0 & $\mathrm{U}_{\mathrm{R}}$ \\
\hline${ }^{243} \mathrm{Am} \quad$ (by counting) & $<7.8 \mathrm{E}-3$ & $<1.7 \mathrm{E}-2$ & - \\
\hline${ }^{242} \mathrm{Cm} \quad$ (by counting) & $8.1 \mathrm{E}-3$ & $1.8 \mathrm{E}-2$ & $\mathrm{U}_{\mathrm{R}}$ \\
\hline${ }^{243 / 244} \mathrm{Cm}_{\text {(by counting) }}$ & $7.8 \mathrm{E}-2$ & $1.7 \mathrm{E}-1$ & $\mathrm{U}_{\mathrm{R}}, \mathrm{U}_{\mathrm{B}}$ \\
\hline $\begin{array}{l}\text { Total Beta } \\
\qquad \text { (by counting) }\end{array}$ & $8.3 E+3$ & $1.8 \mathrm{E}+4$ & - \\
\hline Total Alpha & $7.0 \mathrm{E}+1$ & $1.5 \mathrm{E}+2$ & - \\
\hline $\begin{array}{l}\text { Sum of Alpha } \\
\text { (TRU) } \\
\text { (by summing TRU isotopes } \\
\text { from Np, Pu, Am, and Cm } \\
\text {-all measured by counting } \\
\text { techniques) }\end{array}$ & 7.7 E 0 & $1.7 E+1$ & $\mathrm{~N} / \mathrm{A}$ \\
\hline \multicolumn{4}{|c|}{$\begin{array}{l}\text { QC Flags: - - meets all QC } \\
\mathrm{U}_{\mathrm{B}} \text { - blank exceeds } 5 \% \text { of sample concentration } \\
\mathrm{U}_{\mathrm{O}^{-}} \text {Outlier omitted in reported average analysis }\end{array}$} \\
\hline
\end{tabular}

\subsection{QC FLAGS FOR RADIONUCLIDE MEASUREMENTS ON THE AY-102/C-106}

Eighteen radionuclide determinations required QC flags. Most of the QC flags were for measurements that exceeded the Quality Control Objectives for \% RSD or for failure to meet the Minimum Reportable Quantity. Given the complexity of many of these measurements (measuring trace radionuclides in high-level waste that required a digestion in the shielded cell), we believe these measurements will be acceptable for the characterization needed for waste processing and for regulatory waste compliance purposes. For each analyte with QC flags, Table 7-19 provides the following comments/explanations. 
Table 7-19. QC flags for Radionuclide Measurements on the AY-102/C-106 Solids Fraction

\begin{tabular}{|c|c|c|}
\hline CO & on & num Reportable Quantity \\
\hline $\begin{array}{l}\text { Radio- } \\
\text { nuclide }\end{array}$ & QC Flag & Comments on QC Flag \\
\hline $\begin{array}{l}{ }^{3} \mathrm{H} \\
\text { (by counting) }\end{array}$ & $\mathrm{U}_{\mathrm{M}}$ & $\begin{array}{l}\text { The highest detection limit was } 1.4 \mathrm{E}-1 \mathrm{mCi} / \mathrm{kg} \text { of dry solids, } \\
\text { exceeding the TMRQ for }{ }^{3} \mathrm{H} \text { of } 2.1 \mathrm{E}-2 \text { by a factor of about } 7 \text {. } \\
\text { As discussed in the radiochemistry narrative for }{ }^{3} \mathrm{H} \text {, incomplete } \\
\text { separation on one of the measurements led to higher detection } \\
\text { limits reported for this replicate. However, two of the three distinct } \\
\text { measurements did have detection limits only slightly above the } \\
\text { MRQ. To be conservative, our policy in this document is to report } \\
\text { the highest detection limit of the three distinct measurements, thus } \\
\text { necessitating the QC flag. }\end{array}$ \\
\hline $\begin{array}{l}{ }^{14} \mathrm{C} \\
\text { (by counting) }\end{array}$ & $\begin{array}{l}\mathrm{U}_{\mathrm{B}}, \mathrm{U}_{\mathrm{L}} \\
\mathrm{U}_{\mathrm{S}}\end{array}$ & $\begin{array}{l}\text { The blank analysis for }{ }^{14} \mathrm{C} \text { was } 13 \% \text { of the average analysis. Even } \\
\text { though the blank measurement was low in dpm (about } 40 \text { ), the low } \\
\text { number of dpm for the samples necessitated flagging the analysis } \\
\text { for exceeding the } 5 \% \text { criterion for the blank. The LCS recovery of } \\
133 \% \text { was outside the QCO of } 75-125 \% \text {, and the spike recovery of } \\
128 \% \text { was also outside the QCO of } 75-125 \% \text {. }\end{array}$ \\
\hline${ }^{59} \mathrm{Ni}$ & $\mathrm{U}_{\mathrm{R}}$ & $\begin{array}{l}\text { The } 20 \% \text { RSD for }{ }^{59} \mathrm{Ni} \text { determinations exceeded the } 15 \% \text { RSD for } \\
\text { the QCO. }\end{array}$ \\
\hline${ }^{63} \mathrm{Ni}$ & $\mathrm{U}_{\mathrm{R}}$ & $\begin{array}{l}\text { The } 19 \% \text { RSD for }{ }^{63} \mathrm{Ni} \text { determinations exceeded the } 15 \% \text { RSD for } \\
\text { the QCO. }\end{array}$ \\
\hline $\begin{array}{l}{ }^{79} \mathrm{Se} \\
\text { (by counting) }\end{array}$ & $\mathrm{U}_{\mathrm{M}}$ & $\begin{array}{l}\text { The detection limit on a dry solids basis was } 9.7 \mathrm{E}-2 \mathrm{mCi} / \mathrm{Kg} \text {, } \\
\text { which exceeds the MRQ of } 8.7 \mathrm{E}-3 \mathrm{mCi} / \mathrm{kg} \text { by a factor of } 11 \text {. } \\
\text { Many cleanup steps were required to achieve the detection limit of } \\
9.7 \mathrm{E}-2 \mathrm{mCi} / \mathrm{kg} \text { (see narrative in Section } 76.187 .5 \text { ). Although it is } \\
\text { possible that additional method development would achieve this } \\
\text { detection limit, we report this detection limit as a reasonable and } \\
\text { practical alternative to costly additional work on this radionuclide. } \\
\text { MRQ. }\end{array}$ \\
\hline $\begin{array}{l}{ }^{99} \mathrm{Tc} \text { (by } \\
\text { counting) }\end{array}$ & $\mathrm{U}_{\mathrm{R}}$ & The $\%$ RSD was $29 \%$, exceeding the QCO of $<20 \%$ RSD. QCO \\
\hline $\begin{array}{l}{ }^{125} \mathrm{Sb} \\
\text { (by counting) }\end{array}$ & $\mathrm{U}_{\mathrm{R}}$ & The $\%$ RSD was $22 \%$, exceeding the QCO of $<15 \%$ RSD. QCO \\
\hline $\begin{array}{l}{ }^{126} \mathrm{Sb}, \\
{ }^{126} \mathrm{Sn} \\
\text { (by counting) }\end{array}$ & $\mathrm{U}_{\mathrm{R}}$ & The $\%$ RSD was $23 \%$, exceeding the QCO of $<15 \%$ RSD. QCO \\
\hline & & $\begin{array}{l}\mathrm{U}_{\mathrm{R}} \text { - fails \% RSD criteria } \\
\mathrm{U}_{\mathrm{L}} \text { - fails \% Recovery of LCS } \\
\text { N/A - not applicable }\end{array}$ \\
\hline
\end{tabular}


Table 7-19. QC flags for Radionuclide Measurements on the AY-102/C-106 Solids Fraction - page 2 of 2

\begin{tabular}{|c|c|c|}
\hline $2 \mathrm{CO}=\mathrm{Q}$ & Control & MRQ = Minimum Reportable Quantity \\
\hline $\begin{array}{l}\text { Radio- } \\
\text { nuclide }\end{array}$ & QC Flag & Comments on QC Flag \\
\hline $\begin{array}{l}{ }^{129} \mathrm{I} \\
\text { (by counting) }\end{array}$ & $\mathrm{U}_{\mathrm{R}}, \mathrm{U}_{\mathrm{O}}$ & $\begin{array}{l}\text { The \% RSD was greater than the QCO of }<15 \% \text { because the first } \\
\text { determination was affected by a poor radiochemical separation. To } \\
\text { provide a reasonable average value for }{ }^{129} \mathrm{I} \text {, the first determination } \\
\text { was considered a statistical outlier (defined arbitrarily for this repor } \\
\text { as being a factor of at least } 10 \text { times different than the average of } \\
\text { the other two determinations). The average value was flagged as } \\
\mathrm{U}_{\mathrm{O}} \text { to indicate that the outlier was discarded to obtain the average } \\
\text { of } 2 \text { determinations rather than } 3 \text {. }\end{array}$ \\
\hline${ }^{151} \mathrm{Sm}$ & $\mathrm{U}_{\mathrm{S}}$ & $\begin{array}{l}\text { Although there were no QC requirements for }{ }^{151} \text { Sm listed in either } \\
\text { the Test Specification or the Task Technical and QA Plan, we used } \\
\text { the } 15 \% \text { RSD QCO for precision and } 85-115 \% \text { QCO for LCS and } \\
\text { MS recoveries to assess the QC performance. The MS recovery was } \\
120 \% \text {, requiring a QC flag for matrix spike recovery. The sample } \\
\text { was high in }{ }^{151} \mathrm{Sm} \text {, (roughly } 50 \% \text { more }{ }^{151} \mathrm{Sm} \text { activity than the } \\
{ }^{151} \mathrm{Sm} \text { added to the matrix spike sample) which increased the } \\
\text { uncertainty of the matrix spike recovery calculation. }\end{array}$ \\
\hline $\begin{array}{l}{ }^{235} \mathrm{U} \\
\text { (by ICP-MS) }\end{array}$ & $\mathrm{U}_{\mathrm{R}}$ & The $\%$ RSD was $18 \%$, exceeding the QCO of $<15 \%$. \\
\hline $\begin{array}{l}{ }^{238} \mathrm{Pu} \\
\text { (by counting) }\end{array}$ & $\mathrm{U}_{\mathrm{R}}$ & The $\%$ RSD was $25 \%$, exceeding the QCO of $<15 \%$. \\
\hline $\begin{array}{l}{ }^{239 / 240} \mathrm{Pu} \\
\text { (by counting) }\end{array}$ & $\mathrm{U}_{\mathrm{R}}$ & The $\%$ RSD was $24 \%$, exceeding the QCO of $<15 \%$. \\
\hline $\begin{array}{l}{ }^{239} \mathrm{Pu} \\
\text { (by ICP-MS) }\end{array}$ & $\mathrm{U}_{\mathrm{R}}$ & The $\%$ RSD was $28 \%$, exceeding the QCO of $<15 \%$. \\
\hline $\begin{array}{l}{ }^{241} \mathrm{Pu} \\
\text { (by counting) }\end{array}$ & $\mathrm{U}_{\mathrm{R}}$ & The $\%$ RSD was $35 \%$, exceeding the QCO of $<15 \%$. \\
\hline $\begin{array}{l}{ }^{241} \mathrm{Am} \\
\text { (by counting) }\end{array}$ & $\mathrm{U}_{\mathrm{R}}$ & The $\%$ RSD was $18 \%$, exceeding the QCO of $<15 \%$. \\
\hline $\begin{array}{l}{ }^{242} \mathrm{Cm} \\
\text { (by counting) }\end{array}$ & $\mathrm{U}_{\mathrm{R}}$ & The $\%$ RSD was $20 \%$, exceeding the QCO of $<15 \%$. \\
\hline $\begin{array}{l}{ }^{243 / 244} \mathrm{Cm} \\
\text { (by counting) }\end{array}$ & $\mathrm{U}_{\mathrm{R}}, \mathrm{U}_{\mathrm{B}}$ & $\begin{array}{l}\text { The \% RSD was } 30 \% \text { exceeding the QCO of }<15 \% \text {. The blank } \\
\text { measurement for both the reagent blank and a non-radioactive glass } \\
\text { dissolved in the shielded cells were higher than the actual samples. } \\
\text { This indicates that the level of }{ }^{243 / 244} \mathrm{Cm} \text { contamination in the SRTC } \\
\text { shielded cells is significant enough that accurate }{ }^{243 / 244} \mathrm{Cm} \\
\text { measurements at the concentrations found in Hanford waste would } \\
\text { be difficult, and, in this case, were not obtained. }\end{array}$ \\
\hline \multicolumn{3}{|c|}{$\begin{array}{l}\text { QC Flags: - - meets all QC } \\
\mathrm{U}_{\mathrm{B}} \text { - blank exceeds } 5 \% \text { of sample concentration } \\
\mathrm{U}_{\mathrm{O}^{-}} \text {- Outlier omitted in reported average analysis }\end{array}$} \\
\hline
\end{tabular}


WSRC-TR-2003-00205, REVISION 0 SRT-RPP-2003-00086, REVISION 0

This page intentionally left blank. 


\subsection{COMPARISON OF MEASURED ANALYTES IN UNWASHED AY-102/C-106 SOLIDS TO SPECIFICATION 8, HIGH-LEVEL WASTE ENVELOPE IN WTP CONTRACT}

The analytes in the unwashed AY-102/C-106 solids must be expressed in terms of $\mathrm{g} / 100 \mathrm{~g}$ of waste oxide for stable elements or $\mathrm{Ci} / 100 \mathrm{~g}$ of waste oxide for radionuclides. These values are then compared with the values found in the four tables in Specification 8, High-Level Waste Envelope in WTP Contract. The weight \% solids in the unwashed wet solids $(45.5 \%)$ and the weight $\%$ oxide in the dry solids $(75.1 \%)$ obtained by heating the dry solids to constant weight at $1050{ }^{\circ} \mathrm{C}$ were used along with $\mathrm{mg}$ to gram and $\mathrm{kg}$ to $100 \mathrm{~g}$ conversion factors to obtain a factor for converting the units of $\mathrm{mg}$ analyte $/ \mathrm{kg}$ wet solids to $\mathrm{g} / 100 \mathrm{~g}$ oxide solids:

\section{Unitless Conversion Factor to convert from $\mathrm{mg}$ analyte/kg wet solids to g analyte $/ 100 \mathrm{~g}$ oxide solids $=$}

$\frac{1 g}{1000 \mathrm{mg}} \times \frac{1 \mathrm{~g} \text { wet solids }}{0.45 \mathrm{~g} \text { dry solids }} \times \frac{1 \mathrm{~g} \text { dry solids }}{0.751 \mathrm{~g} \text { oxide solids }} \times \frac{100 \mathrm{~g}(\text { to convert from } \mathrm{kg} \text { to } 100 \mathrm{~g})}{1000 \mathrm{~g}}=2.9 E-4$

For example, the measured concentration of $\mathrm{Mn}$ in the wet unwashed AY-102/C-106 solids was $15,600 \mathrm{mg} / \mathrm{kg}$. By using the $2.9 \mathrm{E}-4$ conversion factor, this value becomes $4.52 \mathrm{~g}$ of $\mathrm{Mn} / 100 \mathrm{~g}$ of waste oxide. This same numerical factor also applies for converting $\mathrm{mCi}$ of radionuclide $/ \mathrm{kg}$ of wet solids to $\mathrm{Ci}$ of radionuclide $/ 100 \mathrm{~g}$ of oxide solids.

Table 8-1 - Table 8-4 have the measured concentration of analyte in either $\mathrm{mg} / \mathrm{kg}$ or $\mathrm{mCi} / \mathrm{kg}$ and the conversion to $\mathrm{g}$ analyte/100 $\mathrm{g}$ waste oxide or $\mathrm{Ci}$ radionuclide/100 $\mathrm{g}$ waste oxide. This concentration was then divided by the maximum concentration of analyte per Specification 8 and converted to a \% of maximum value. All analytes in AY-102/C-106 were below $100 \%$ of the maximum value, and most by a wide margin.

The ${ }^{233} \mathrm{U}$ values were given a special QC notation of being from only one determination. The

${ }^{233} \mathrm{U}$ concentration was just above the detection limit in the most concentrated of the serial dilutions used in the ICP-MS determination. Since only one of the three replicate determinations was serially diluted, this meant that only one measurement on each type of digestion was performed. However, the values obtained by the ICP-MS on each type of digestion agreed to within about $25 \%$. These values for ${ }^{233} \mathrm{U}$ were about $30 \%$ of the maximum allowed value. The Test Specification listed the maximum concentration of ${ }^{233} \mathrm{U}$ as $9.0 \mathrm{E}-7 \mathrm{Ci} / 100 \mathrm{~g}$ waste oxide. The maximum concentration of ${ }^{233} \mathrm{U}$ was increased to $4.5 \mathrm{E}-6 \mathrm{Ci} / 100 \mathrm{~g}$ waste oxide in modification A029 of the WTP Prime Contract with DOE:No. DE-AC27-01RV14136. 
Table 8-4 (corresponding to Table TS-8.4 in Specification 8) differs from Table 8-1 - Table 8-3 because the maximum value is only a suggested maximum concentration as opposed to a more explicit required maximum concentration in Table 8-1 - Table 8-3. The only analyte that exceeded the suggested maximum in Table $8-4$ was $\mathrm{Na}$ at $115 \%$ of the maximum.

Table 8-1. Comparison of Measured Concentration of Non-Volatile Elements in AY-102/C-106 Unwashed Solids vs. Maximum Concentration Per Hanford Specification 8

Corresponds to Table TS.8.1 in Hanford Specification 8

\begin{tabular}{|c|c|c|c|c|c|}
\hline $\begin{array}{c}\text { Non- } \\
\text { Volatile } \\
\text { Element }\end{array}$ & $\begin{array}{c}\text { Average } \\
\text { Concentration } \\
\text { of Element in } \\
\text { Wet Solids from } \\
\text { Table } 7-15 \\
(\mathrm{mg} / \mathrm{kg}) \\
\end{array}$ & $\begin{array}{c}\text { Average } \\
\text { Concentration } \\
\text { of Element in } \\
\text { Calcined Solids } \\
\begin{array}{c}\text { (g/100 g waste } \\
\text { oxide) }\end{array} \\
\end{array}$ & $\begin{array}{c}\text { Specification } 8 \\
\text { Maximum } \\
\\
\text { (g element / } \\
100 \text { g } \\
\text { waste oxide) }\end{array}$ & $\begin{array}{c}\% \% \text { of } \\
\text { Maximum }\end{array}$ & $\begin{array}{c}\text { Does measured } \\
\text { concentration } \\
\text { of element } \\
\text { meet } \\
\text { Specification } 8 \\
\text { Limits? }\end{array}$ \\
\hline As & $<20$ & $<0.0001$ & 0.16 & $<1 \%$ & Yes \\
\hline B & 24 & 0.007 & 1.3 & $<1 \%$ & Yes \\
\hline $\mathrm{Be}$ & $<1$ & $<0.0002$ & 0.065 & $<1 \%$ & Yes \\
\hline $\mathrm{Ce}$ & 660 & 0.19 & 0.81 & $23 \%$ & Yes \\
\hline $\mathrm{Co}$ & 17 & 0.005 & 0.45 & $1 \%$ & Yes \\
\hline Cs & 16 & 0.005 & 0.58 & $<1 \%$ & Yes \\
\hline $\mathrm{Cu}$ & 140 & 0.04 & 0.48 & $10 \%$ & Yes \\
\hline $\mathrm{Hg}$ & 147 & 0.04 & 0.1 & $40 \%$ & Yes \\
\hline $\mathrm{La}$ & 440 & 0.13 & 2.6 & $5 \%$ & Yes \\
\hline $\mathrm{Li}$ & 215 & 0.06 & 0.14 & $<45 \%$ & Yes \\
\hline $\mathrm{Mn}$ & 15,600 & 4.52 & 6.5 & $70 \%$ & Yes \\
\hline Mo & $<15$ & $<0.004$ & 0.65 & $<1 \%$ & Yes \\
\hline $\mathrm{Nd}$ & 990 & 0.29 & 1.7 & $17 \%$ & Yes \\
\hline $\operatorname{Pr}$ & 280 & 0.08 & 0.35 & $23 \%$ & Yes \\
\hline $\begin{array}{c}\mathrm{Pu} \\
\text { (total) }\end{array}$ & 18 & 0.005 & 0.054 & $10 \%$ & Yes \\
\hline $\mathrm{Rb}$ & $<6$ & $<0.002$ & 0.19 & $<1 \%$ & Yes \\
\hline $\mathrm{Sb}$ & $<6$ & $<0.002$ & 0.84 & $<1 \%$ & Yes \\
\hline
\end{tabular}


WSRC-TR-2003-00205, REVISON 0 SRT-RPP-2003-00086, REVISION 0

Table 8-1. Comparison of Measured Concentration of Non-Volatile Elements in AY-102/C-106 Unwashed Solids vs. Maximum Concentration per Hanford Specification 8 - page 2 of 2

Corresponds to Table TS.8.1 in Hanford Specification 8

\begin{tabular}{|c|c|c|c|c|c|}
\hline $\begin{array}{c}\text { Non- } \\
\text { Volatile } \\
\text { Element }\end{array}$ & $\begin{array}{c}\text { Average } \\
\text { Concentration } \\
\text { of Element in } \\
\text { Wet Solids from } \\
\text { Table 7-15 } \\
\text { (mg/kg) }\end{array}$ & $\begin{array}{c}\text { Average } \\
\text { Concentration } \\
\text { of Element in } \\
\text { Calcined Solids } \\
\text { (g/100 g waste } \\
\text { oxide) }\end{array}$ & $\begin{array}{c}\text { Specification 8 } \\
\text { Maximum } \\
\text { (gaste oxide) } \\
\text { 100 g }\end{array}$ & $\begin{array}{c}\text { \%of } \\
\text { Maximum }\end{array}$ & $\begin{array}{c}\text { Does measured } \\
\text { concentration } \\
\text { of element } \\
\text { meet } \\
\text { Specification 8 } \\
\text { Limits? }\end{array}$ \\
\hline $\mathrm{Se}$ & $<20$ & $<0.006$ & 0.52 & $1 \%$ & Yes \\
\hline $\mathrm{Sr}$ & 600 & 0.17 & 0.52 & $33 \%$ & Yes \\
\hline $\mathrm{Ta}$ & 10 & $<0.002$ & 0.03 & $<7 \%$ & Yes \\
\hline $\mathrm{Tc}$ & 3 & 0.0008 & 0.26 & $<1 \%$ & Yes \\
\hline $\mathrm{Te}$ & 33 & 0.009 & 0.13 & $7 \%$ & Yes \\
\hline $\mathrm{Tl}$ & 2 & 0.009 & 0.45 & $2 \%$ & Yes \\
\hline $\mathrm{V}$ & 10 & 0.003 & 0.032 & $9 \%$ & Yes \\
\hline $\mathrm{W}$ & 245 & 0.07 & 0.24 & $29 \%$ & Yes \\
\hline $\mathrm{Y}$ & 124 & 0.04 & 0.16 & $22 \%$ & Yes \\
\hline $\mathrm{Zn}$ & 199 & 0.06 & 0.42 & $14 \%$ & Yes \\
\hline
\end{tabular}


WSRC-TR-2003-00205, REVISON 0 SRT-RPP-2003-00086, REVISION 0

Table 8-2. Comparison of Measured Concentration of Volatile Components in AY-102/C-106 Unwashed Solids vs. Maximum Concentration Per Hanford Specification 8

Corresponds to Table TS.8.2 in Hanford Specification 8

\begin{tabular}{|c|c|c|c|c|c|}
\hline $\begin{array}{c}\text { Volatile } \\
\text { Compo } \\
\text { nent }\end{array}$ & $\begin{array}{c}\text { Average } \\
\text { Concentration } \\
\text { of Volatile } \\
\text { Component in } \\
\text { Wet Solids from } \\
\text { Table 7-2 } \\
(\mathrm{mg} / \mathrm{kg}) \\
\end{array}$ & $\begin{array}{c}\text { Average } \\
\text { Concentration } \\
\text { of Volatile } \\
\text { Component in } \\
\text { Calcined Solids } \\
\\
(\mathrm{g} / \mathbf{1 0 0} \mathrm{g} \\
\text { waste oxide) } \\
\end{array}$ & $\begin{array}{c}\text { Specification } 8 \\
\text { Maximum } \\
\text { Volatile } \\
\text { Component } \\
\\
\text { (g/ 100 g } \\
\text { waste oxide) } \\
\end{array}$ & $\begin{array}{c}\% \text { of } \\
\text { Maximum }\end{array}$ & $\begin{array}{c}\text { Does measured } \\
\text { concentration } \\
\text { of element } \\
\text { meet } \\
\text { Specification } 8 \\
\text { Limits? }\end{array}$ \\
\hline $\mathrm{Cl}^{-}$ & 140 & 0.04 & 0.33 & $12 \%$ & Yes \\
\hline $\begin{array}{l}\mathrm{CO}_{3}^{2-} \\
\text { (from } \\
\text { Total } \\
\text { Inorganic } \\
\text { Carbon ) } \\
\end{array}$ & 43,700 & 12.7 & 30 & $42 \%$ & Yes \\
\hline $\mathrm{NO}_{2}^{-}$ & 1,963 & 0.57 & \multirow{2}{*}{$\begin{array}{c}\text { Total } \\
\left(\mathrm{NO}_{2}+\mathrm{NO}_{3}\right) \\
36\end{array}$} & \multirow[t]{2}{*}{$2 \%$} & \multirow[t]{2}{*}{ Yes } \\
\hline $\mathrm{NO}_{3}^{-}$ & 223 & 0.06 & & & \\
\hline TOC & 5,300 & 1.54 & 11 & $14 \%$ & Yes \\
\hline $\begin{array}{c}\mathrm{CN}^{-} \\
\text {(from } \\
\text { BWXT) }\end{array}$ & 13.2 & 0.004 & 1.6 & $0.2 \%$ & Yes \\
\hline $\begin{array}{c}\mathrm{NH}_{3} \\
\text { (from } \\
\text { BWXT) }\end{array}$ & $<99.4$ & $<0.03$ & 1.6 & $<2 \%$ & Yes \\
\hline
\end{tabular}


Table 8-3. Comparison of Measured Concentration of Radionuclides in AY-102/C-106 Unwashed Solids vs. Maximum Concentration Per Hanford Specification 8

Corresponds to Table TS.8.3 in Hanford Specification 8

\begin{tabular}{|c|c|c|c|c|c|}
\hline $\begin{array}{l}\text { Radio- } \\
\text { nuclide }\end{array}$ & \begin{tabular}{|c|} 
Average \\
Concentration of \\
Radionuclide in \\
Wet Solids from \\
Table 7-17 \\
$(\mathrm{mCi} / \mathrm{kg})$
\end{tabular} & $\begin{array}{l}\text { Average } \\
\text { Concentration of } \\
\text { Radionuclide in } \\
\text { Calcined Solids } \\
\text { (gCi/100 g waste } \\
\quad \text { oxide) }\end{array}$ & $\begin{array}{l}\text { Specification } 8 \\
\text { Maximum } \\
\\
\text { (Ci } \\
\text { radionuclide/ } \\
100 \mathrm{~g} \\
\text { waste oxide) }\end{array}$ & $\begin{array}{c}\text { \% of } \\
\text { Maximum }\end{array}$ & $\begin{array}{c}\text { Does measured } \\
\text { concentration of } \\
\text { Radionuclide } \\
\text { meet } \\
\text { Specification } 8 \\
\text { Limits? }\end{array}$ \\
\hline${ }^{3} \mathrm{H}$ & $<6.5 \mathrm{E}-2$ & $1.9 \mathrm{E}-5$ & 6.5 E- 5 & $29 \%$ & Yes \\
\hline${ }^{14} \mathrm{C}$ & $3 E-4$ & $9.8 \mathrm{E}-8$ & 6.5 E- 6 & $2 \%$ & Yes \\
\hline${ }^{60} \mathrm{Co}$ & $1.2 \mathrm{E}-1$ & $3.4 E-5$ & $1 E-2$ & $<1 \%$ & Yes \\
\hline${ }^{90} \mathrm{Sr}$ & $3.7 E+3$ & $1.07 \mathrm{E} 0$ & $1 \mathrm{E}+1$ & $11 \%$ & Yes \\
\hline${ }^{99} \mathrm{Tc}$ & $5.0 \mathrm{E}-2$ & $1.4 \mathrm{E}-5$ & $1.5 \mathrm{E}-2$ & $<\%$ & Yes \\
\hline${ }^{125} \mathrm{Sb}$ & $4.9 E-2$ & $1.4 \mathrm{E}-5$ & $3.2 \mathrm{E}-2$ & $<1 \%$ & Yes \\
\hline${ }^{126} \mathrm{Sn}$ & $1.9 \mathrm{E}-2$ & $5.5 \mathrm{E}-6$ & $1.5 \mathrm{E}-4$ & $4 \%$ & Yes \\
\hline${ }^{129} \mathrm{I}$ & $6.5 \mathrm{E}-5$ & $1.9 \mathrm{E}-8$ & $2.9 \mathrm{E}-7$ & $6 \%$ & Yes \\
\hline${ }^{137} \mathrm{Cs}$ & $2.5 \mathrm{E}+2$ & $7.1 \mathrm{E}-2$ & $1.5 \mathrm{E} 0$ & $5 \%$ & Yes \\
\hline${ }^{152} \mathrm{Eu}$ & $9.5 \mathrm{E}-2$ & $2.7 \mathrm{E}-5$ & $4.8 E-4$ & $6 \%$ & Yes \\
\hline${ }^{154} \mathrm{Eu}$ & $2.1 \mathrm{E} 0$ & $6.0 \mathrm{E}-4$ & $5.2 \mathrm{E}-2$ & $1 \%$ & Yes \\
\hline${ }^{155} \mathrm{Eu}$ & $1.1 \mathrm{E} 0$ & $3.2 \mathrm{E}-4$ & $2.9 E-2$ & $1 \%$ & Yes \\
\hline $\begin{array}{c}{ }^{233} \mathrm{U} \\
\text { (from } \\
\text { Serial } \\
\text { dilution } \\
\text { of Aqua } \\
\text { Regia } \\
\text { Digest.) }\end{array}$ & $3.8 \mathrm{E}-3$ & $1.1 \mathrm{E}-6$ & $\begin{array}{c}4.5 \mathrm{E}-6 \\
\text { (see table } \\
\text { footnote a.) }\end{array}$ & $24 \%$ & Yes \\
\hline $\begin{array}{c}{ }^{233} \mathrm{U} \\
\text { (from } \\
\text { Serial } \\
\text { dilution } \\
\text { of KOH } \\
\text { Fusion } \\
\text { Digest.) }\end{array}$ & $4.8 \mathrm{E}-3$ & $1.4 \mathrm{E}-6$ & $\begin{array}{c}4.5 \mathrm{E}-6 \\
\text { (see table } \\
\text { footnote a.) }\end{array}$ & $31 \%$ & Yes \\
\hline
\end{tabular}


Table 8-3. Comparison of Measured Concentration of Radionuclides in AY-102/C-106 Unwashed Solids vs. Maximum Concentration Per Hanford Specification 8 page 2 of 2

Corresponds to Table TS.8.3 in Hanford Specification 8

\begin{tabular}{|c|c|c|c|c|c|}
\hline $\begin{array}{c}\text { Radio- } \\
\text { nuclide }\end{array}$ & $\begin{array}{c}\text { Average } \\
\text { Concentration } \\
\text { of Radionuclide } \\
\text { in Wet Solids } \\
\text { from Table 7-17 }\end{array}$ & $\begin{array}{c}\text { Average } \\
\text { Concentration } \\
\text { of Radionuclide } \\
\text { in Calcined } \\
\text { Solids } \\
\text { (mCi/kg })\end{array}$ & $\begin{array}{c}\text { Specification 8 } \\
\text { Maximum } \\
\text { (gCi/100 g } \\
\text { waste oxide) }\end{array}$ & $\begin{array}{c}\text { \% of } \\
\text { radionuclide/ } \\
\mathbf{1 0 0} \text { g } \\
\text { waste oxide) }\end{array}$ & $\begin{array}{c}\text { Does measured } \\
\text { concentration of } \\
\text { Radionuclide } \\
\text { meet } \\
\text { Specification 8 } \\
\text { Limits? }\end{array}$ \\
\hline${ }^{235} \mathrm{U}$ & $3.7 \mathrm{E}-5$ & $1.6 \mathrm{E}-8$ & $2.5 \mathrm{E}-7$ & $4 \%$ & Yes \\
\hline${ }^{237} \mathrm{~Np}$ & $5.7 \mathrm{E}-3$ & $1.64 \mathrm{E}-6$ & $7.4 \mathrm{E}-5$ & $2 \%$ & Yes \\
\hline${ }^{238} \mathrm{Pu}$ & $2.1 \mathrm{E}-1$ & $1 \mathrm{E}-4$ & $3.5 \mathrm{E}-4$ & $17 \%$ & Yes \\
\hline${ }^{239} \mathrm{Pu}$ & $1.0 \mathrm{E} 0$ & $3 \mathrm{E}-4$ & $3.1 \mathrm{E}-3$ & $9 \%$ & Yes \\
\hline${ }^{241} \mathrm{Pu}$ & $2.0 \mathrm{E} 0$ & $6 \mathrm{E}-4$ & $2.2 \mathrm{E}-2$ & $3 \%$ & Yes \\
\hline${ }^{241} \mathrm{Am}$ & $4.1 \mathrm{E} 0$ & $1.2 \mathrm{E}-3$ & $9.0 \mathrm{E}-2$ & $1 \%$ & Yes \\
\hline${ }^{243+244} \mathrm{Cm}$ & $7.8 \mathrm{E}-2$ & $2.2 \mathrm{E}-5$ & $3.0 \mathrm{E}-3$ & $1 \%$ & Yes \\
\hline
\end{tabular}

a. The Test Specification listed the maximum ${ }^{233} \mathrm{U}$ concentration as $9.0 \mathrm{E}-7 \mathrm{mCi} / 100 \mathrm{~g}$ waste oxide. The maximum concentration of ${ }^{233} \mathrm{U}$ was increased to $4.5 \mathrm{E}-6 \mathrm{mCi} / 100 \mathrm{~g}$ waste oxide in modification A029 of the WTP Prime Contract with DOE: No. DE-AC2701RV14136. 
Table 8-4. Comparison of Measure Concentration of Non-Volatile Elements in AY-102/C-106 Unwashed Solids vs. Maximum Recommended Concentration Per Hanford Specification 8

Corresponds to Table TS.8.4 in Hanford Specification 8

\begin{tabular}{|c|c|c|c|c|c|}
\hline $\begin{array}{c}\text { Non- } \\
\text { Volatile } \\
\text { Element }\end{array}$ & $\begin{array}{c}\text { Average } \\
\text { Concentration } \\
\text { of Element in } \\
\text { Wet Solids from } \\
\text { Table 7-15 } \\
\text { (mg/kg })\end{array}$ & $\begin{array}{c}\text { Average } \\
\text { Concentration } \\
\text { of Element in } \\
\text { Calcined Solids } \\
\text { (g/100 g waste } \\
\text { oxide) }\end{array}$ & $\begin{array}{c}\text { Specification 8 } \\
\text { Maximum } \\
\text { (g element / } \\
\mathbf{1 0 0} \text { g } \\
\text { waste oxide) }\end{array}$ & $\begin{array}{c}\text { \% of } \\
\text { Maximum }\end{array}$ & $\begin{array}{c}\text { Does measured } \\
\text { concentration of } \\
\text { Radionuclide } \\
\text { meet } \\
\text { Specification 8 } \\
\text { Limits? }\end{array}$ \\
\hline $\mathrm{Ag}$ & 1,290 & 0.37 & 0.55 & $69 \%$ & Yes \\
\hline $\mathrm{Al}$ & 32,300 & 9.4 & 14 & $67 \%$ & Yes \\
\hline $\mathrm{Ba}$ & 500 & 0.14 & 4.5 & $3 \%$ & Yes \\
\hline $\mathrm{Bi}$ & 25 & 0.007 & 2.8 & $<1 \%$ & Yes \\
\hline $\mathrm{Cr}$ & 1,290 & 0.37 & 0.68 & $55 \%$ & Yes \\
\hline $\mathrm{F}$ & 446 & 0.13 & 3.5 & $4 \%$ & Yes \\
\hline $\mathrm{K}$ & 420 & 0.12 & 1.3 & $9 \%$ & Yes \\
\hline $\mathrm{Mg}$ & 670 & 0.19 & 2.1 & $9 \%$ & Yes \\
\hline $\mathrm{Na}$ & $\mathbf{7 5 , 3 0 0}$ & $\mathbf{2 1 . 8}$ & $\mathbf{1 9}$ & $\mathbf{1 1 5 \%}$ & No \\
\hline $\mathrm{Ni}$ & 2,410 & 0.69 & 2.4 & $29 \%$ & Yes \\
\hline $\mathrm{P}$ & 1,310 & 0.38 & 1.7 & $22 \%$ & Yes \\
\hline $\mathrm{Pb}$ & 3,270 & 0.94 & 1.1 & $85 \%$ & Yes \\
\hline $\mathrm{Pd}$ & $<50$ & $<0.01$ & 0.13 & $<10 \%$ & Yes \\
\hline $\mathrm{Rh}$ & 21 & 0.006 & 0.13 & $5 \%$ & Yes \\
\hline $\mathrm{Ru}$ & 230 & 0.066 & 0.35 & $19 \%$ & Yes \\
\hline $\mathrm{S}$ & 830 & 0.24 & 0.65 & $37 \%$ & Yes \\
\hline $\mathrm{Si}$ & 20,600 & 6.02 & 19 & $32 \%$ & Yes \\
\hline $\mathrm{Th}$ & 490 & 0.14 & 5.0 & $3 \%$ & Yes \\
\hline $\mathrm{Ti}$ & 143 & 0.04 & 1.3 & $3 \%$ & Yes \\
\hline $\mathrm{U}$ & 2,450 & 0.71 & 14 & $5 \%$ & Yes \\
\hline $\mathrm{Zr}$ & 2,570 & 0.74 & 15 & $5 \%$ & Yes \\
\hline
\end{tabular}


WSRC-TR-2003-00205, REVISON 0

SRT-RPP-2003-00086, REVISION 0

This page intentionally left blank. 


\subsection{COMPARISON OF INHIBITED WATER LEACH, PLANT LEACH PROCEDURE, AND SPECIFICATION 12 LEACH PROCEDURE}

The original Test Specification called for the AY-102/C-106 solid fraction to be washed with 3-5 volumes of $0.01 \mathrm{M} \mathrm{NaOH}$. The liquid and solid phases resulting after separating the phases by centrifugation would then be analyzed analogously to the liquid and solid phases of the as-received (unwashed) AY-102/C-106. Soon after the characterization work on AY102/C-106 began, SRTC and WTP personnel considered more efficient ways of combining characterization and pretreatment studies. One of the major drivers for reconsidering the technical focus was the fact that the $3.8 \mathrm{~L}$ ( $4.6 \mathrm{~kg}$ ) of AY-102/C-106 sludge had only about 5.9 $\%$ insoluble solids. We had some concerns that the roughly $270 \mathrm{~g}$ of solids in AY-102/C-106 sludge would be inadequate to perform all the characterization, washing, leaching, filtration tests, etc., and still provide enough sludge for the filtration and vitrification studies also part of the AY-102/C-106 program.

An important element of the WTP contract is to determine if high-level waste streams will require a caustic leach to reduce aluminum concentrations in the sludge to facilitate waste processing in the WTP. To make this determination, the high-level sludge composition is to be compared after a relatively simple $0.01 \mathrm{M} \mathrm{NaOH}$ wash with the composition after a multi-step procedure involving 23 washes with $0.01 \mathrm{M} \mathrm{NaOH}$ solution, then a hot caustic leach, then 23 more $0.01 \mathrm{M} \mathrm{NaOH}$ washes. This wash/leach/wash procedure is called the Plant Leach Procedure and it is currently the reference wash/leach procedure at Hanford. Another candidate leach procedure, the Specification 12 Leach Procedure, also uses a wash/leach/wash protocol but with many fewer $0.01 \mathrm{M} \mathrm{NaOH}$ washes (5 total versus 46 total) than the Plant Leach Procedure. To compensate for the fewer $0.01 \mathrm{M} \mathrm{NaOH}$ washes, the Specification 12 Leach Procedure uses larger wash volumes to remove interstitial salts and liquids from the solids.

SRTC and WTP personnel sized up the goals of the washing/leaching programs and adopted Test Exceptions from the simple $0.01 \mathrm{M} \mathrm{NaOH}$ wash followed by extensive analysis of the products as stipulated in the Test Specification. The two pertinent Test Exceptions were:

- Test Exception Number: 24590-WTP-TEF-RT-02-031; Originators: K.H. Abel and A.V. Arakali; Originating Date: 7/01/2002.

- Test Exception Number: 24590-WTP-TEF-RT-02-047; Originator: A.V. Arakali; Originating Date: 8/07/2002. 
The agreed-upon technical path included the following experiments:

- Perform the 0.01 M NaOH wash, the Plant Leach Procedure, and the Specification 12 Leach Procedure on relatively small amounts of AY-102/C-106 sludge at SRTC.

- Analyze the resulting solids, wash waters, and caustic leach solutions for only those components pertinent to appraising the result of each wash or leach test.

- Compare the composition of the residual solids after the 0.01 M NaOH wash, Plant Leach Procedure, and Specification 12 Leach Procedure to determine which protocol will be used by SRTC to produce treated AY-102/C-106 solids in tests of the Cells Unit Filter (CUF). The Pretreatment Technology Group at WTP made the ultimate decision and recommended that the Plant Leach Procedure be used for AY-102/C-106 solids.

- Shift the bulk of the analyses from the product of the $0.01 \mathrm{M} \mathrm{NaOH}$ wash to the product of the Plant Leach Procedure since it will be the actual pretreatment process used. By changing this emphasis, significant analytical costs were eliminated by minimizing the analyses of the $0.01 \mathrm{M} \mathrm{NaOH}$ wash, a process that was not indicated for AY-102/C-106 pretreatment.

\subsection{01 M NAOH WASH OF AY-102/C-106 SOLID FRACTION}

\section{Experimental Procedure for the 0.01 M NaOH Wash of the AY-102/C-106 Solid Fraction}

Four trials of the following method were performed: $5 \mathrm{~mL}$ of the as-received AY-102/C-106 slurry was transferred to a $30 \mathrm{~mL}$ Teflon Oak Ridge type centrifuge and the weight of the $5 \mathrm{~mL}$ recorded. The slurry was spun at approximately $8000 \mathrm{rpm}$ for 1 hour. The supernatant fraction was decanted away and set side for other analyses on the supernatant fraction. The wet solids remaining in the tube were weighed. The volume of wet solids was estimated at about $1 \mathrm{~mL}$ based primarily on previous measurements of the volume \% solids at about $18 \%$ (Table 5.1). Since the Test Specification stipulates that 3-5 volumes of 0.01 M NaOH are to be added to resuspend the solids, we chose to use $5 \mathrm{~mL}$ to achieve about a 5:1 volume ratio of $0.01 \mathrm{M} \mathrm{NaOH}$ to wet solids. After re-suspending the mixture, the centrifuge tubes were agitated for 8 hours at ambient cell temperatures $\left(22-27^{\circ} \mathrm{C}\right)$. The tubes were then spun at about $8000 \mathrm{rpm}$ for 1 hour and the liquid phase containing the $0.01 \mathrm{M} \mathrm{NaOH}$ wash was decanted into a plastic bottle and weighed. The residual wet solids in the centrifuge tube were also weighed.

The wash solution was removed from the cells and transferred to a radiohood for dilution. The wash solution was diluted to exactly $10 \mathrm{~mL}$, and $2 \mathrm{~mL}$ of this solution was removed for anion analysis by ion chromatography. The $8 \mathrm{~mL}$ remaining was diluted with dropwise addition of $2 \mathrm{~mL}$ concentrated $\mathrm{HCl}$ and this solution was analyzed for metal content by ICP-AES.

The residual wet solids after the $0.01 \mathrm{M} \mathrm{NaOH}$ wash were dissolved with the hot $\mathrm{HF}-\mathrm{HNO}_{3}$ $\mathrm{HCl}-\mathrm{H}_{3} \mathrm{BO}_{3}$ digestion method discussed previously in Section 7.1.4. A portion of this solution was then removed from the shielded cells and analyzed for metal content by ICP-AES.

The pertinent weights of residual solids and wash solutions are shown in Table 9-1. 
Table 9-1. Weights of Liquid and Solid Fractions in Inhibited Water Wash

\begin{tabular}{|l|c|c|c|c|}
\hline \multirow{2}{*}{ Weight of 5 mL of AY-102/C-106 } & Trial 1 & Trial 2 & Trial 3 & Trial 4 \\
\cline { 2 - 5 } & $5.962 \mathrm{~g}$ & $6.005 \mathrm{~g}$ & $6.032 \mathrm{~g}$ & $6.030 \mathrm{~g}$ \\
\hline Weight of unwashed residual solids after centrifuga. & $1.910 \mathrm{~g}$ & $1.367 \mathrm{~g}$ & $1.462 \mathrm{~g}$ & $2.431 \mathrm{~g}$ \\
\hline Weight of decanted 0.01 M NaOH wash & $4.280 \mathrm{~g}$ & $4.914 \mathrm{~g}$ & $4.885 \mathrm{~g}$ & $4.746 \mathrm{~g}$ \\
\hline Weight of residual solids after 0.01 M NaOH wash & $1.210 \mathrm{~g}$ & $1.272 \mathrm{~g}$ & $1.223 \mathrm{~g}$ & $1.565 \mathrm{~g}$ \\
\hline
\end{tabular}

\subsection{ELEMENTAL AND ANION ANALYSIS OF THE WASH SOLUTIONS AFTER 4 TRIALS OF THE O.01 M NAOH WASH PROCEDURE}

The concentration of elements and anions in the $0.01 \mathrm{M} \mathrm{NaOH}$ wash solutions are shown in Table 9-2.The concentrations are reasonably consistent with the dilution incurred by the soluble salts in the interstitial supernatant. For example, a $1.3 \mathrm{~g}$ sample of wet as-received solids following centrifugation and decanting of the supernatant would be expected to contain about 0.6 grams of true solids and about 0.7 grams of interstitial supernatant. Addition of the $5.0 \mathrm{~mL}$ of $0.01 \mathrm{M} \mathrm{NaOH}$ would introduce a dilution factor of roughly 8 , thus reducing the concentration of nitrite in the as-received supernatant (Table 6.2) from about $5,000 \mathrm{mg} / \mathrm{L}$ or $4,350 \mathrm{mg} / \mathrm{kg}$ using the density of the supernatant at $1.15 \mathrm{~g} / \mathrm{mL}$ to about $540 \mathrm{mg} / \mathrm{kg}$. In Table 9-2, we see that the measured nitrite concentration was about $600 \mathrm{mg} / \mathrm{kg}$, an entirely reasonable concentration.

Table 9-2. Elemental and Anion Analysis of the Wash Solutions after 4 Trials of the 0.01 M NaOH Wash Procedure

All Elemental Determinations by ICP-AES;

All Anion Determinations by IC

\begin{tabular}{|c|c|c|c|c|}
\hline Analyte & $\begin{array}{c}\text { Trial 1 Analysis of } \\
\text { Wash Water } \\
(\mathbf{m g} / \mathbf{k g})\end{array}$ & $\begin{array}{c}\text { Trial 2 Analysis of } \\
\text { Wash Water } \\
(\mathbf{m g} / \mathbf{k g})\end{array}$ & $\begin{array}{c}\text { Trial 3 Analysis of } \\
\text { Wash Water } \\
(\mathbf{m g} / \mathbf{k g})\end{array}$ & $\begin{array}{c}\text { Trial 4 Analysis of } \\
\text { Wash Water } \\
\text { (mg/kg) }\end{array}$ \\
\hline $\mathrm{Ag}$ & 5 & 4 & 4 & 5 \\
\hline $\mathrm{Al}$ & 685 & 600 & 605 & 622 \\
\hline $\mathrm{Ba}$ & $<1$ & $<1$ & $<1$ & $<1$ \\
\hline $\mathrm{Be}$ & $<1$ & $<1$ & $<1$ & $<1$ \\
\hline $\mathrm{Ca}$ & $<1$ & $<1$ & $<1$ & $<1$ \\
\hline $\mathrm{Cd}$ & $<1$ & $<1$ & $<1$ & $<1$ \\
\hline $\mathrm{Cr}$ & 14 & 12 & 12 & 9 \\
\hline $\mathrm{Fe}$ & 2 & 1 & 1 & $<2$ \\
\hline $\mathrm{Li}$ & $<2$ & $<2$ & $<2$ & $<1$ \\
\hline $\mathrm{Mg}$ & $<1$ & $<1$ & $<1$ & \\
\hline
\end{tabular}


Table 9-2. Elemental and Anion Analysis of the Wash Solutions after 4 Trials of the 0.01 M NaOH Wash Procedure - page 2 of 2

All Elemental Determinations by ICP-AES;

All Anion Determinations by IC

\begin{tabular}{|c|c|c|c|c|}
\hline Analyte & $\begin{array}{c}\text { Trial } 1 \text { Analysis } \\
\text { of Wash Water } \\
(\mathrm{mg} / \mathrm{kg})\end{array}$ & $\begin{array}{c}\text { Trial } 2 \text { Analysis } \\
\text { of Wash Water } \\
(\mathrm{mg} / \mathrm{kg})\end{array}$ & $\begin{array}{c}\text { Trial } 3 \text { Analysis } \\
\text { of Wash Water } \\
(\mathrm{mg} / \mathrm{kg})\end{array}$ & $\begin{array}{c}\text { Trial } 4 \text { Analysis } \\
\text { of Wash Water } \\
(\mathrm{mg} / \mathrm{kg})\end{array}$ \\
\hline $\mathrm{Mn}$ & $<1$ & $<1$ & $<1$ & $<1$ \\
\hline $\mathrm{Na}$ & 12,400 & 10,500 & 10,700 & 10,900 \\
\hline $\mathrm{Ni}$ & $<1$ & $<1$ & $<1$ & $<1$ \\
\hline $\mathrm{P}$ & 206 & 176 & 180 & 189 \\
\hline $\mathrm{Pb}$ & $<5$ & $<5$ & $<5$ & $<5$ \\
\hline$S$ & 111 & 95 & 100 & 102 \\
\hline $\mathrm{Si}$ & 12 & 11 & 11 & 14 \\
\hline $\mathrm{Sr}$ & $<1$ & $<1$ & $<1$ & $<1$ \\
\hline $\mathrm{Ti}$ & $<2$ & $<2$ & $<2$ & $<2$ \\
\hline $\mathrm{U}$ & $<529$ & $<529$ & $<529$ & $<529$ \\
\hline $\mathrm{Zn}$ & $<2$ & $<2$ & $<2$ & $<2$ \\
\hline $\mathrm{Zr}$ & $<2$ & $<2$ & $<2$ & $<2$ \\
\hline Nitrate & 49 & 47 & 45 & 46 \\
\hline Nitrite & 614 & 587 & 582 & 601 \\
\hline Sulfate & 283 & 257 & 260 & 268 \\
\hline Formate & 37 & 37 & 37 & 40 \\
\hline Oxalate & 705 & 670 & 656 & 681 \\
\hline Phosphate & 484 & 444 & 453 & 468 \\
\hline Fluoride & 9 & 8 & 8 & 8 \\
\hline Chloride & 16 & 14 & 16 & 15 \\
\hline Bromide & 82 & 77 & 76 & 78 \\
\hline
\end{tabular}




\subsection{ELEMENTAL ANALYSIS OF THE RESIDUAL WET SOLIDS AFTER 4 TRIALS OF THE 0.01 M NAOH WASH PROCEDURE}

Table 9-3 displays the elemental compositions of the residual wet solids from four trials of the $0.01 \mathrm{M} \mathrm{NaOH}$ Wash and compares them with the composition of the wet un-washed solids (from Table 7-15). Good experimental reproducibility was obtained, reflecting the relative simplicity of performing the $0.01 \mathrm{M} \mathrm{NaOH}$ wash in the cells. Nevertheless, the overall reproducibility also includes the cell digestion and the analytical determinations. Trial 4 analysis differs significantly from the other three trials, but we chose to include this trial to better reflect the normal precision of shielded cell experiments. 
Table 9-3. Elemental Analysis of the Residual Wet Solids After 4 Trials of the Inhibited Water Wash Procedure

Solids Digested with hot $\mathrm{HF}-\mathrm{HNO}_{3}-\mathrm{HCl}-\mathrm{H}_{3} \mathrm{BO}_{3}$.

All Elemental Determinations by ICP-AES)

\begin{tabular}{|c|c|c|c|c|c|c|}
\hline Analyte & $\begin{array}{c}\text { Average } \\
\text { Analysis } \\
\text { On } \\
\text { Unwashed } \\
\text { Wet } \\
\text { Solids } \\
\text { (from } \\
\text { Table 7- } \\
\text { 15) }\end{array}$ & $\begin{array}{c}\text { Trial 1 } \\
\text { Analysis } \\
\text { of } \\
\text { Residual } \\
\text { Solids } \\
\text { (mg/kg) }\end{array}$ & $\begin{array}{c}\text { Trial } 2 \\
\text { Analysis } \\
\text { of } \\
\text { Residual } \\
\text { Solids } \\
\text { (mg/kg) }\end{array}$ & $\begin{array}{c}\text { Trial } 3 \\
\text { Analysis } \\
\text { of } \\
\text { Residual } \\
\text { Solids } \\
(\mathrm{mg} / \mathrm{kg})\end{array}$ & $\begin{array}{c}\text { Trial } 4 \\
\text { Analysis } \\
\text { of } \\
\text { Residual } \\
\text { Solids } \\
(\mathrm{mg} / \mathrm{kg})\end{array}$ & $\begin{array}{c}\text { Average } \\
\text { Analysis } \\
\text { of } \\
\text { Residual } \\
\text { Solids } \\
(\mathrm{mg} / \mathrm{kg})\end{array}$ \\
\hline $\mathrm{Ag}$ & 1,290 & 355 & 407 & 221 & 287 & 318 \\
\hline $\mathrm{Al}$ & 32,300 & 38,000 & 37,100 & 37,800 & 33,600 & 36,600 \\
\hline $\mathrm{Ba}$ & 500 & 477 & 462 & 472 & 392 & 451 \\
\hline $\mathrm{Be}$ & $<1$ & $<1$ & $<1$ & $<1$ & $<1$ & $<1$ \\
\hline $\mathrm{Ca}$ & 2,500 & 2,940 & 2,820 & 2,910 & 3,830 & 3,125 \\
\hline $\mathrm{Cd}$ & 100 & 97 & 100 & 98 & 72 & 92 \\
\hline $\mathrm{Cr}$ & 1,290 & 1,490 & 1,330 & 1,340 & 1,040 & 1,300 \\
\hline $\mathrm{Fe}$ & 72,900 & 82,000 & 81,200 & 82,200 & 62,900 & 77,100 \\
\hline $\mathrm{Li}$ & 215 & 239 & 205 & 237 & 193 & 219 \\
\hline $\mathrm{Mg}$ & 670 & 742 & 722 & 746 & 1,000 & 800 \\
\hline $\mathrm{Mn}$ & 15,600 & 17,300 & 17,100 & 17,500 & 13,400 & 16,300 \\
\hline $\mathrm{Na}$ & 75,300 & 37,300 & 34,700 & 37,000 & 32,000 & 35,250 \\
\hline $\mathrm{Ni}$ & 2,410 & 2,740 & 2,680 & 2,710 & 2,070 & 2,550 \\
\hline $\mathrm{P}$ & 3,100 & 2,230 & 2,110 & 2,220 & 1,270 & 1,960 \\
\hline $\mathrm{Pb}$ & 3,260 & 3,670 & 3,710 & 3,770 & 2,860 & 3,500 \\
\hline $\mathrm{S}$ & 830 & 616 & 767 & 667 & 640 & 673 \\
\hline $\mathrm{Si}$ & 20,600 & $\begin{array}{c}\text { N/A HF } \\
\text { causes high } \\
\text { Si bias }\end{array}$ & $\begin{array}{c}\text { N/A HF } \\
\text { causes high } \\
\text { Si bias }\end{array}$ & $\begin{array}{c}\text { N/A HF } \\
\text { causes high } \\
\text { Si bias }\end{array}$ & $\begin{array}{c}\text { N/A HF } \\
\text { causes high } \\
\text { Si bias }\end{array}$ & $\begin{array}{c}\text { N/A HF } \\
\text { causes high } \\
\text { Si bias }\end{array}$ \\
\hline $\mathrm{Sr}$ & 600 & 786 & 735 & 778 & 962 & 815 \\
\hline $\mathrm{Ti}$ & 143 & 154 & 148 & 154 & 184 & 160 \\
\hline $\mathrm{Zn}$ & 199 & 16 & 30 & 11 & 175 & 58 \\
\hline $\mathrm{Zr}$ & 2,570 & 2,740 & 2,640 & 2,750 & 2,170 & 2,580 \\
\hline
\end{tabular}




\subsection{PLANT LEACH PROCEDURE OF AY-102/C-106 SOLID FRACTION}

\section{Experimental Procedure for the Plant Leach Procedure of the AY-102/C-106 Solid Fraction}

The Plant Leach Procedure was performed only in duplicate (we would have preferred at least 4 replicate leaches and analyses of the residual solids) because the AY-102/C-106 material needed to be used for other purposes, including demonstration of the Cells Unit Filter and for vitrification studies. Twenty (20) mL of as-received AY-102/C-106 slurry was transferred into a 30-mL Teflon Oak Ridge type centrifuge tube and weighed. The slurry was spun in a bench top centrifuge in the shielded cells for 1 hour. The supernatant was decanted away and set aside for other analyses. The wet solid fraction was weighed. The pertinent weights are listed in Table 9-4.

The Plant Leach Procedure stipulates treatment of $1 \mathrm{~L}$ of sludge with 23 washes of $62.5 \mathrm{~mL}$ of $0.01 \mathrm{M} \mathrm{NaOH}$. Since the $20 \mathrm{~mL}$ of as-received slurry yields only about $4-5 \mathrm{~mL}$ of wet solids, the volume of $0.01 \mathrm{M} \mathrm{NaOH}$ wash water for an experiment of this scale was only about 0.32 $\mathrm{mL}$. The experimental challenge was to ensure that the added wash water was distributed throughout the sludge. We spent a day in a non-radiological laboratory investigating ways to mix the thick sludge with the small amount of added wash water. We determined that we could achieve reasonable mixing by using both a vortex mixer and literally beating the bottom of the tube against a fixed object, such as the bench top.

Application of this method in the shielded cells was obviously more difficult, but followed the same method worked out in the non-radiological laboratory. After addition of the $0.32 \mathrm{ml}$ of $0.01 \mathrm{M} \mathrm{NaOH}$, the cell operator would spend at least 15 minutes per tube mixing the slurry with the vortex mixer and then striking the bottom of the tube to agitate the mixture. The cell operators were instructed that the success of the experiment depended on the entire solid sample coming into contact with fresh wash water. After mixing, the duplicate centrifuge tubes were spun at $8000 \mathrm{rpm}$ for 1 hour. The supernatants resulting from centrifugation of the duplicate trials were then combined into a plastic bottle for measuring the weight. (The supernatant phases after each wash were combined to obtain a more manageable volume for dilutions.) This procedure was done 23 times before the caustic leach step and 23 times after the caustic leach step.

The weight of each of the combined supernatant solutions after the $460.01 \mathrm{M} \mathrm{NaOH}$ washes is shown in Table 9-4. Nominally the volume of the combined water washes would be expected to be about $0.64 \mathrm{~mL}$ if a perfect $0.01 \mathrm{M} \mathrm{NaOH}$ wash addition and separation were executed. Some of the weights of wash solutions varied considerably from this weight $(0.64 \mathrm{~g})$ even taking the approximate density of the wash solutions into account. In particular, the weight of the initial water wash was about 3.2 grams. This wash solution also had an extraordinarily high $\mathrm{Na}$ concentration. This result may indicate that some of the $\mathrm{Na}$ dissolved with the initial $0.01 \mathrm{M} \mathrm{NaOH}$ wash and combined with the interstitial salts to create a wash solution that both weighed more and was higher in $\mathrm{Na}$ than would be expected from a simple dilution of the interstitial solution with the $0.01 \mathrm{M} \mathrm{NaOH}$ wash. The extremely high $\mathrm{Na}$ concentration in the first wash solution may be an indication of analytical error. 
Some of the $0.01 \mathrm{M} \mathrm{NaOH}$ washes weighed less than half of the $0.64 \mathrm{~g}$. In this case, it is likely that an imperfect centrifugation and separation step resulted in a low recovery of wash water. In all cases, the solution weights were used to calculate the dilution factor so the amount of sample collected does not affect the concentration of analytes measured in each individual wash solution.

The initial $230.01 \mathrm{M} \mathrm{NaOH}$ washes reduced the weight of the wet solids about $40 \%$ (Table 9-4) from removal of soluble salts and some minor loss of sludge fines in the decanting step. (These sludge fines undoubtedly contribute in some cases to the analyte concentrations of such elements as $\mathrm{Fe}, \mathrm{Ca}, \mathrm{Mn}, \mathrm{Al}$ in the wash waters.) Teflon Oak Ridge type centrifuge tubes have excellent mechanical strength (however, see the following discussion on the loss of a sample from a cracked tube) and chemical inertness, but the shape does not lend itself to perfect separation of supernatant from solid.

The residual solids after the first set of $230.01 \mathrm{M} \mathrm{NaOH}$ washes were treated with $5 \mathrm{~mL}$ of $3 \mathrm{M} \mathrm{NaOH}$ for 8 hours at $85^{\circ} \mathrm{C}$. We had no means of heating the centrifuge tubes and mixing them simultaneously, so after each hour the tubes were removed from the oven and shaken vigorously to mix the leach solution with the solids. The tubes were then spun at about $8000 \mathrm{rpm}$ for one hour. The caustic leach solution from each tube (not combined as in the case of the $0.01 \mathrm{M} \mathrm{NaOH}$ washes) was transferred to plastic bottles for measuring the solution weights.

The residual solids after the caustic leach were then washed 23 more times with $0.01 \mathrm{M} \mathrm{NaOH}$. The wash waters were collected and weighed analogous to the 23 washes before caustic leaching.

Both the $0.01 \mathrm{M} \mathrm{NaOH}$ washes and the caustic leach solutions were removed from the cells for further dilution and analyses. The solutions were diluted to exactly $10 \mathrm{~mL}$ and then $2 \mathrm{~mL}$ of this solution removed for anion analysis by ion chromatography. The $8 \mathrm{~mL}$ of remaining solution was diluted to $10 \mathrm{~mL}$ by dropwise addition of concentrated $\mathrm{HCl}$ for metals analysis by ICP-AES. The elemental and anion composition of selected $0.01 \mathrm{M} \mathrm{NaOH}$ washes and the caustic leach solutions are shown in Table 9-6.

The residual solids after the Plant Leach procedure of $460.01 \mathrm{M} \mathrm{NaOH}$ washes and a caustic leach were weighed and dissolved with the hot $\mathrm{HF}-\mathrm{HNO}-\mathrm{HCl}-\mathrm{H}_{3} \mathrm{BO}_{3}$ digestion method discussed in Section 7.1.4. It was during the digestion of one of the replicate samples that we had a catastrophic failure of one of the Teflon centrifuge tubes. As we picked up one of the tubes to observe the completion of digestion, a large amount of the acid solution leaked from the bottom of the tube before we could get the tube back into its secondary holder. Obviously the integrity of this analysis was lost, but we continued with the workup of this solution because we had only duplicate trials and we hoped we could get some information from the ratio of analytes. The hairline crack in the bottom of the Teflon tube probably resulted from a combination of the radiation of the samples and the physical abuse we inflicted on the tube in our external mixing efforts. It is possible that the hairline crack developed much earlier in the Plant Leach Procedure, but was not observed until we added the acid to form a fluid solution. 
No problems were noted in the work-up of the other tube. The digestions from both tubes were removed from the shielded cells and analyzed for metals content by ICP-AES. The elemental analysis of both replicates of the digested residual solids from the Plant Leach Procedure is shown in Table 9-6.

Table 9-4. Weights of Residual Solids and Wash Solutions in the Plant Leach Procedure Performed on AY-102/C-106 Solid Fraction

\begin{tabular}{|c|c|c|c|c|c|c|c|}
\hline & & & & Trial 1 & Trial 2 \\
\hline \multicolumn{6}{|c|}{ Weight of $20 \mathrm{~mL}$ of AY-102/C-106 } & $23.296 \mathrm{~g}$ & $23.824 \mathrm{~g}$ \\
\hline \multicolumn{6}{|c|}{ Weight of unwashed residual solids after centrifugation } & $5.285 \mathrm{~g}$ & $5.444 \mathrm{~g}$ \\
\hline \multicolumn{6}{|c|}{ Weight of residual solids after $1^{\text {st }}$ set of $230.01 \mathrm{M} \mathrm{NaOH}$ washes } & $2.998 \mathrm{~g}$ & $2.903 \mathrm{~g}$ \\
\hline \multicolumn{6}{|c|}{ Weight of residual solids after caustic leach } & $3.361 \mathrm{~g}$ & $3.753 \mathrm{~g}$ \\
\hline \multicolumn{6}{|c|}{$\begin{array}{l}\text { Weight of residual solids after } 2^{\text {nd }} \text { set of } 230.01 \mathrm{M} \mathrm{NaOH} \text { washes } \\
\text { (final product of the Plant Leach Procedure) and digested with the } \\
\mathrm{HF}-\mathrm{HNO}_{3}-\mathrm{HCl}-\mathrm{H}_{3} \mathrm{BO}_{3} \text { procedure }\end{array}$} & $2.971 \mathrm{~g}$ & $2.632 \mathrm{~g}$ \\
\hline \multicolumn{6}{|c|}{$\begin{array}{l}\text { Weight of the } 3 \mathrm{M} \mathrm{NaOH} \text { caustic leach solution decanted after } \\
\text { centrifuging to separate from the leach solids }\end{array}$} & $5.289 \mathrm{~g}$ & $4.472 \mathrm{~g}$ \\
\hline \multicolumn{8}{|c|}{$\begin{array}{c}\text { Weights of the } 1^{\text {st }} \text { set of } 230.01 \mathrm{M} \text { NaOH washes collected after decanting from } \\
\text { solid fraction }\end{array}$} \\
\hline $\begin{array}{c}1 * \\
3.216 \mathrm{~g}\end{array}$ & $\begin{array}{c}4^{*} \\
0.610 \mathrm{~g}\end{array}$ & $\begin{array}{c}7 * \\
0.742 \mathrm{~g}\end{array}$ & $\begin{array}{l}10 * \\
0.340 \mathrm{~g}\end{array}$ & $\begin{array}{r}13 * \\
0.700 \mathrm{~g}\end{array}$ & $\begin{array}{r}16 * \\
0.655 \mathrm{~g}\end{array}$ & $\begin{array}{c}19 * \\
0.914 \mathrm{~g}\end{array}$ & $\begin{array}{c}22 \\
0.477 \mathrm{~g}\end{array}$ \\
\hline $\begin{array}{c}2 \\
0.902 \mathrm{~g}\end{array}$ & $\begin{array}{c}\mathbf{5} \\
0.718 \mathrm{~g}\end{array}$ & $\begin{array}{c}8 \\
0.605 \mathrm{~g}\end{array}$ & $\begin{array}{c}11 \\
0.628 \mathrm{~g}\end{array}$ & $\begin{array}{c}14 \\
0.656 \mathrm{~g}\end{array}$ & $\begin{array}{c}17 \\
0.442 \mathrm{~g}\end{array}$ & $\begin{array}{c}\mathbf{2 0} \\
0.681 \mathrm{~g}\end{array}$ & $\begin{array}{c}23 * \\
0.611 \mathrm{~g}\end{array}$ \\
\hline $\begin{array}{c}3 \\
1.230 \mathrm{~g} \\
\end{array}$ & $\begin{array}{c}6 \\
0.669 \mathrm{~g} \\
\end{array}$ & $\begin{array}{c}9 \\
0.704 \mathrm{~g} \\
\end{array}$ & $\begin{array}{c}12 \\
0.492 \mathrm{~g}\end{array}$ & $\begin{array}{c}15 \\
0.705 \mathrm{~g}\end{array}$ & $\begin{array}{c}18 \\
0.614 \mathrm{~g}\end{array}$ & $\begin{array}{c}21 \\
0.515 \mathrm{~g}\end{array}$ & \\
\hline \multicolumn{8}{|c|}{$\begin{array}{c}\text { Weights of the } 2^{\text {nd }} \text { set of } 230.01 \mathrm{M} \mathrm{NaOH} \text { washes collected after decanting from } \\
\text { solid fraction }\end{array}$} \\
\hline $\begin{array}{l}\mathbf{2 4 *} \\
1.394 \mathrm{~g}\end{array}$ & $\begin{array}{c}27 \\
0.817 \mathrm{~g}\end{array}$ & $\begin{array}{c}\mathbf{3 0} \\
\text { sample lost }\end{array}$ & $\begin{array}{c}33 \\
0.526 \mathrm{~g}\end{array}$ & $\begin{array}{c}36 \\
0.679 \mathrm{~g}\end{array}$ & $\begin{array}{c}39 \\
0.553 \mathrm{~g}\end{array}$ & $\begin{array}{c}42 \\
0.637 \mathrm{~g}\end{array}$ & $\begin{array}{c}45 \\
0.825 \mathrm{~g}\end{array}$ \\
\hline $\begin{array}{c}25 \\
1.056 \mathrm{~g}\end{array}$ & $\begin{array}{r}28 * \\
0.639 \mathrm{~g}\end{array}$ & $\begin{array}{c}\mathbf{3 1 *} \\
0.609 \mathrm{~g}\end{array}$ & $\begin{array}{c}34 * \\
0.757 \mathrm{~g}\end{array}$ & $\begin{array}{c}37 * \\
0.689 \mathrm{~g}\end{array}$ & $\begin{array}{c}\mathbf{4 0} * \\
0.719 \mathrm{~g}\end{array}$ & $\begin{array}{c}\mathbf{4 3} * \\
0.361\end{array}$ & $\begin{array}{c}46 * \\
0.669 \\
\end{array}$ \\
\hline $\begin{array}{c}\mathbf{2 6} \\
0.517 \mathrm{~g}\end{array}$ & $\begin{array}{c}\mathbf{2 9} \\
0.628 \mathrm{~g}\end{array}$ & $\begin{array}{c}32 \\
0.705 \mathrm{~g}\end{array}$ & $\begin{array}{c}35 \\
0.478 \mathrm{~g}\end{array}$ & $\begin{array}{c}38 \\
0.637 \mathrm{~g}\end{array}$ & $\begin{array}{c}\mathbf{4 1} \\
0.526 \mathrm{~g}\end{array}$ & $\begin{array}{c}44 \\
0.353 \mathrm{~g}\end{array}$ & \\
\hline
\end{tabular}

* denotes solutions that were analyzed 


\subsection{PLANT LEACH PROCEDURE WASH AND LEACH SOLUTIONS}

All $460.01 \mathrm{M} \mathrm{NaOH}$ wash solutions and the replicate caustic leach solutions were collected and weighed. Only every $4^{\text {th }}$ inhibited water wash was analyzed for elemental and anion composition to minimize analytical cost. The $0.01 \mathrm{M} \mathrm{NaOH}$ wash analyses were in general consistent with the dilution and removal of the interstitial solution from the wet solids. One result that we cannot explain is the very high $\mathrm{Na}$ value $(350,000 \mathrm{mg} / \mathrm{kg})$ on the first $0.01 \mathrm{M} \mathrm{NaOH}$ wash. Since the Na concentration in the AY-102/C-106 supernatant is only about $75,000 \mathrm{mg} / \mathrm{L}$ or $65,000 \mathrm{mg} / \mathrm{kg}$ correcting for the density of the supernatant, this Na value seems an order of magnitude too high.

The elemental analysis of the caustic leach solution when compared with the last of the $0.01 \mathrm{M} \mathrm{NaOH}$ wash solutions shows that the hot caustic leach is dissolving insoluble $\mathrm{Al}$ compounds rather than simply removing the $\mathrm{Al}$ in the interstitial supernatant. The $\mathrm{Al}$ concentration increases over 20 -fold in the hot caustic leach solution.

The caustic solutions were not analyzed for anion content since analysis of the $2^{\text {nd }}$ set of 23 $0.01 \mathrm{M} \mathrm{NaOH}$ washes indicated that only phosphate was affected by the caustic leach. The elemental analyses of the caustic leach solutions show significant increases in P concentration. Since the $\mathrm{P}$ and phosphate concentration track reasonably well in the $0.01 \mathrm{M} \mathrm{NaOH}$ washes from the ICP-AES and IC analyses, respectively, the phosphate concentration in the caustic leach solutions can be estimated at about $600 \mathrm{mg} / \mathrm{kg}$. 
Table 9-5. Plant Leach Procedure Wash and Leach Solutions

All Concentrations in $\mathrm{mg} / \mathrm{kg}$

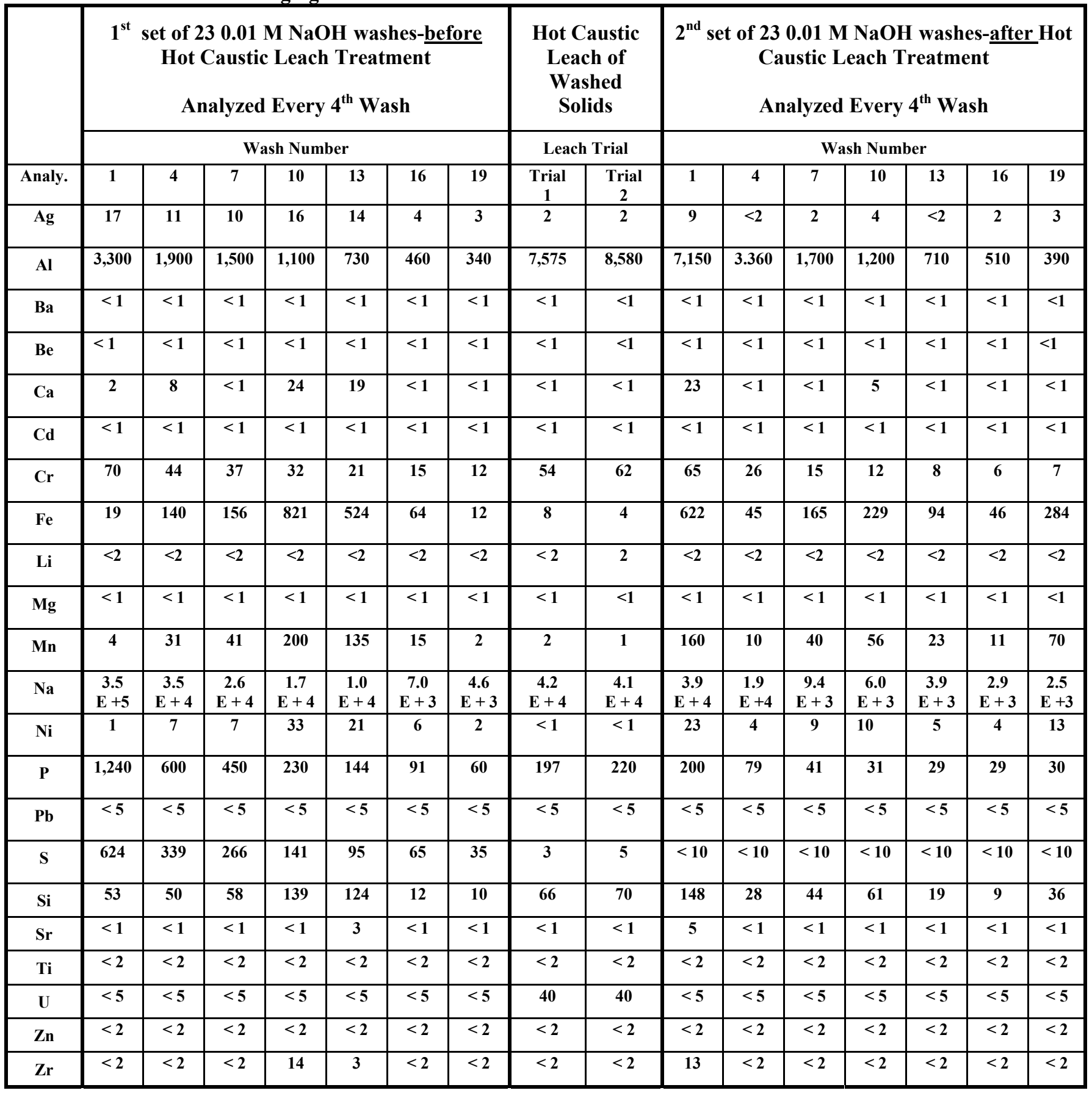


Table 9-5. Plant Leach Procedure Wash and Leach Solutions - page 2 of 2

All Concentrations in $\mathrm{mg} / \mathrm{kg}$

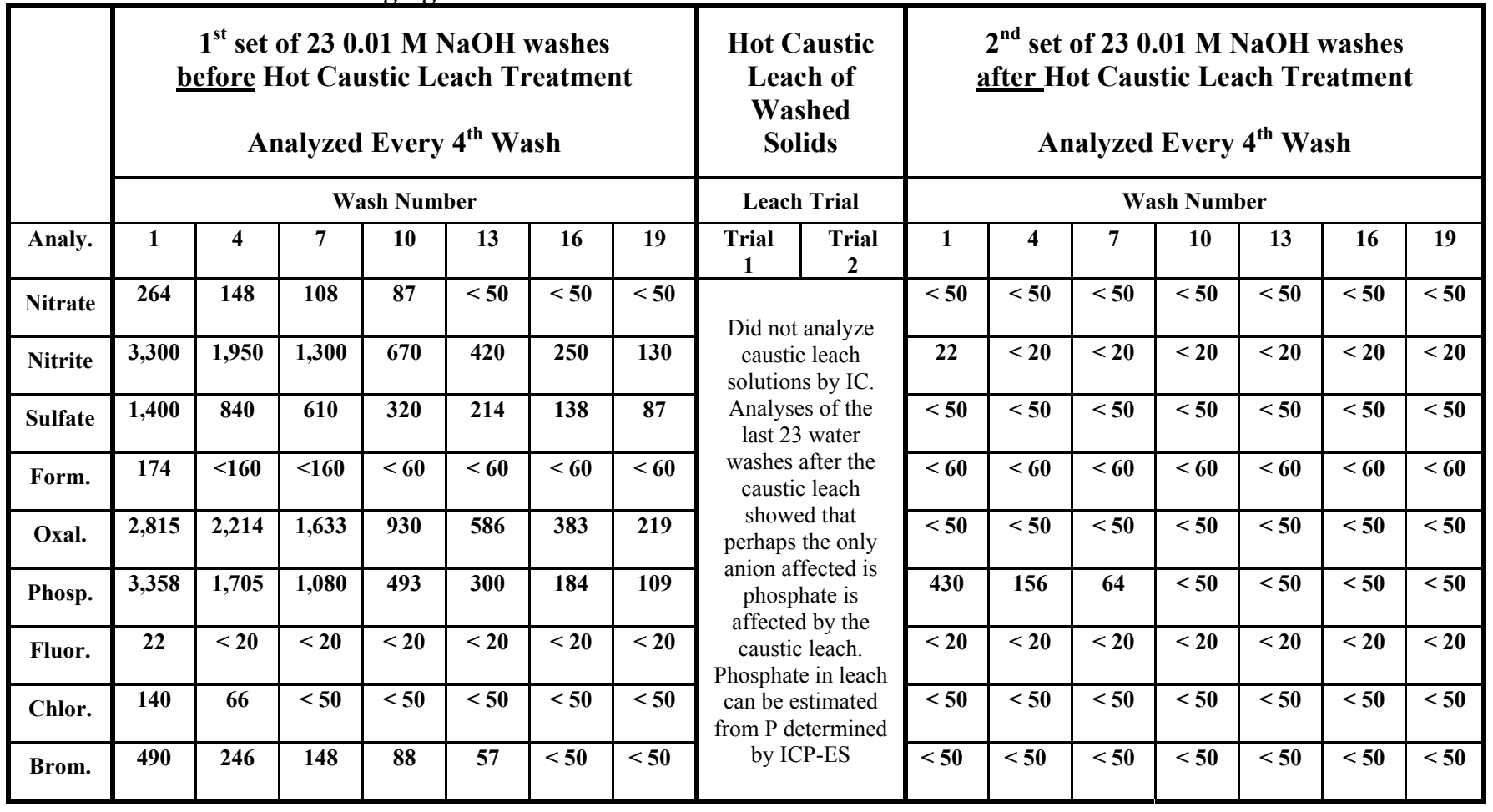

\subsection{ELEMENTAL ANALYSIS OF THE RESIDUAL WET SOLIDS AFTER THE PLANT LEACH PROCEDURE}

The elemental analyses of the wet solid residue after the Plant Leach Procedure are shown in Table 9-6. The first replicate is about $20-25 \%$ of the second replicate, a manifestation of the loss of sample that resulted from a cracked centrifuge tube. However, the second replicate produced reasonable elemental concentrations that can be compared (see Section 9.10) with the composition of the residual solids from the $0.01 \mathrm{M} \mathrm{NaOH}$ Wash and the Specification 12 Leach Procedure. 
Table 9-6. Elemental Analysis of the Residual Wet Solids after the Plant Leach Procedure

All Elemental Determinations by ICP-AES

\begin{tabular}{|c|c|c|}
\hline Analyte & $\begin{array}{l}\text { Trial } 1 \text { Analysis On Residual } \\
\text { Wet Solids Following Plant } \\
\text { Leach Procedure (mg/kg) }\end{array}$ & $\begin{array}{c}\text { Trial } 2 \text { Analysis On Residual Wet } \\
\text { Solids Following Plant Leach } \\
\text { Procedure (mg/kg) }\end{array}$ \\
\hline $\mathrm{Ag}$ & $<54$ & 238 \\
\hline $\mathrm{Al}$ & 6,750 & 30,800 \\
\hline $\mathrm{Ba}$ & $<128$ & 570 \\
\hline $\mathrm{Be}$ & $<6$ & $<6$ \\
\hline $\mathrm{Ca}$ & 1,130 & 4,340 \\
\hline $\mathrm{Cd}$ & $<28$ & 115 \\
\hline $\mathrm{Cr}$ & 375 & 1,780 \\
\hline $\mathrm{Fe}$ & 26,000 & 122,000 \\
\hline $\mathrm{Li}$ & $<290$ & 233 \\
\hline $\mathrm{Mg}$ & 92 & 997 \\
\hline $\mathrm{Mn}$ & 5,770 & 25,800 \\
\hline $\mathrm{Na}$ & 18,500 & 40,600 \\
\hline $\mathrm{Ni}$ & 957 & 3,980 \\
\hline $\mathrm{P}$ & 2,800 & 2,420 \\
\hline $\mathrm{Pb}$ & 1,050 & 5,880 \\
\hline $\mathrm{S}$ & $<922$ & 605 \\
\hline $\mathrm{Si}$ & N/A- HF causes high bias & N/A- HF causes high bias \\
\hline $\mathrm{Sr}$ & 179 & 990 \\
\hline $\mathrm{Ti}$ & $<52$ & 149 \\
\hline $\mathrm{Zn}$ & 143 & 278 \\
\hline $\mathrm{Zr}$ & 1,340 & 3,220 \\
\hline
\end{tabular}

Note: A hairline leak developed in the Teflon centrifuge tube used in the Plant Leach Procedure and digestion of the Trial 1 residual solids. This leak resulted in sample loss and rendered the analytical results of Trial 1useless. The Trial 1 analysis is documented in the table, but this result was not used to produce an average result. Only the single result of Trial 2 was used for comparison with other wash/leach procedures. 


\subsection{SPECIFICATION 12 LEACH PROCEDURE}

\section{Experimental Procedure for the Specification 12 Leach Procedure of the AY-102/C-106 Solids Fraction}

Only duplicate Specification 12 Leach Procedures were performed because the AY-102/C-106 material needed to be used for other purposes, including demonstration of the Cells Unit Filter and for vitrification studies. Twenty (20) $\mathrm{mL}$ of as-received AY-102/C-106 slurry was transferred into a 30-mL Teflon Oak Ridge type centrifuge tube and weighed. The slurry was spun in a bench top centrifuge in the shielded cells for 1 hour. The supernatant was decanted and set aside for other analyses. The wet solid fraction was weighed upon completion of the entire Specification 12 Leach Procedure. The pertinent weights of wash solutions and the residual solids are listed in Table 9-7.

The 4-5 $\mathrm{mL}$ of wet solids remaining after removing the supernatant were treated 6 times to produce the residual solids and wash and leach solutions for analysis:

1. Wash with $15 \mathrm{~mL} 0.01 \mathrm{M} \mathrm{NaOH}$; centrifuge mixture for 1 hour at $8000 \mathrm{rpm}$; decant, collect, and weigh the wash water fraction.

2. Repeat Step 1.

3. Repeat Step 1.

4. Heat residual solids after the three $0.01 \mathrm{M} \mathrm{NaOH}$ washes with $15 \mathrm{~mL}$ of $3 \mathrm{M} \mathrm{NaOH}$ for 8 hours at $85 \pm 5{ }^{\circ} \mathrm{C}$, with removal of the tubes and thorough manual agitation every hour. After 8 hours of caustic leaching, centrifuge mixture for 1 hour, decant, collect, and weigh the caustic leach solution.

5. Heat residual solids after caustic leach with $20 \mathrm{~mL} 0.01 \mathrm{M} \mathrm{NaOH}$ solution for 8 hours at $85 \pm 5{ }^{\circ} \mathrm{C}$, with removal of the tubes and thorough manual agitation every hour; centrifuge mixture for 1 hour; decant, collect, and weigh the $0.01 \mathrm{M} \mathrm{NaOH}$ wash solution.

6. Repeat Step 5. In addition, weigh the residual wet solids after the entire Specification 12 Leach Procedure.

The larger volumes of wash water and leach solutions employed in the Specification 12 Leach Procedure obviated the need to combine rinses. We chose to use all the water washes and caustic leaches of one of the trials for anion analyses and to use the analogous solutions from the other trial for the elemental analyses. The solutions for anion determinations were analyzed without further treatment or dilution. The solutions for elemental analysis were diluted with $\mathrm{HCl}$, then diluted to known volume with de-ionized water to produce an acid solution for ICP-AES analysis.

The residual solids after the Specification 12 Leach Procedure were dissolved with the hot $\mathrm{HF}-\mathrm{HNO}_{3}-\mathrm{HCl}-\mathrm{H}_{3} \mathrm{BO}_{3}$ digestion method discussed previously in Section 7.1.4. During the digestion work ups in the cells, a small amount of one of the replicates was spilled before it could be diluted to known volume when the cell operator temporarily lost control of the holder used for the centrifuge tube. Although this accident clearly corrupted the elemental analysis, we decided to show this result since only two analyses were performed. 
Table 9-7. Weights of Residual Solids and Wash Solutions in the Specification 12 Leach Procedure Performed on AY-102/C-106 Solids Fraction

\begin{tabular}{|l|c|c|}
\cline { 2 - 3 } \multicolumn{1}{c|}{} & Trial 1 & Trial 2 \\
\hline Weight of $20 \mathrm{~mL}$ of AY-102/C-106 & $23.908 \mathrm{~g}$ & $24.010 \mathrm{~g}$ \\
\hline Weight of unwashed residual solids after centrifugation & $5.666 \mathrm{~g}$ & $5.816 \mathrm{~g}$ \\
\hline Weight of supernatant collected after $1^{\text {st }} 0.01 \mathrm{M} \mathrm{NaOH}$ Wash & $15.669 \mathrm{~g}$ & $16.254 \mathrm{~g}$ \\
\hline Weight of supernatant collected after $2^{\text {nd }} 0.01 \mathrm{M} \mathrm{NaOH}$ Wash & $14.924 \mathrm{~g}$ & $14.602 \mathrm{~g}$ \\
\hline Weight of supernatant collected after $3^{\text {rd }} 0.01 \mathrm{M} \mathrm{NaOH}$ Wash & $14.753 \mathrm{~g}$ & $14.646 \mathrm{~g}$ \\
\hline Weight of supernatant collected after Caustic Leach & $16.658 \mathrm{~g}$ & $16.652 \mathrm{~g}$ \\
\hline Weight of supernatant collected after $4^{\text {th }} 0.01 \mathrm{M} \mathrm{NaOH}$ Wash & $20.450 \mathrm{~g}$ & $21.098 \mathrm{~g}$ \\
\hline Weight of supernatant collected after $5^{\text {th }} 0.01 \mathrm{M} \mathrm{NaOH}$ Wash & $22.110 \mathrm{~g}$ & $20.272 \mathrm{~g}$ \\
\hline $\begin{array}{l}\text { Weight of residual wet solids after entire Specification } 12 \mathrm{Leach} \\
\text { Procedure (sample digested for elemental analysis) }\end{array}$ & $3.786 \mathrm{~g}$ & $3.002 \mathrm{~g}$ \\
\hline
\end{tabular}

Note: The wash and leach solutions from Trial 1 were analyzed unaltered for anions by IC techniques. The wash and leach solutions from Trial 2 were acidified and diluted to known volume for metals analysis by ICP-AES. The residual solids from both trials were digested with the hot $\mathrm{HF}-\mathrm{HNO}_{3}-\mathrm{HCl}-\mathrm{H}_{3} \mathrm{BO}_{3}$ digestion method before metals analysis by ICP-AES.

\subsection{SPECIFICATION 12 LEACH PROCEDURE WASH AND LEACH SOLUTIONS}

The elemental and anion analyses of the $50.01 \mathrm{M} \mathrm{NaOH}$ washes and the caustic leach for each of the two trials are shown in Table 9-8. The soluble analyte concentrations of the $0.01 \mathrm{M}$ $\mathrm{NaOH}$ washes agree reasonably well with the values expected from a simple dilution of approximately 3 grams of interstitial supernatant (the amount of liquid expected in about 5.5 grams of wet unwashed AY-102/C-106 solids) diluted with $15 \mathrm{~mL}$ of wash water. The most important analysis is that of the caustic leach solution. As was also seen in the caustic leach step of the Plant Leach Procedure, the hot caustic leach step of the Specification 12 Leach Procedure dissolves a portion of the Al compounds as expected. 
Table 9-8. Elemental and Anion Composition of the Five 0.01 M NaOH Washes and the Hot Caustic Leach Solution of the Specification 12 Leach Procedure

All Concentrations in $\mathrm{mg} / \mathrm{kg}$

\begin{tabular}{|c|c|c|c|c|c|c|}
\hline \multirow[b]{3}{*}{ Analyte } & \multicolumn{3}{|c|}{$\begin{array}{c}1^{\text {st }} \text { set of } 30.01 \mathrm{M} \mathrm{NaOH} \text { washes } \\
\text { before Hot Caustic Leach Treatment }\end{array}$} & \multirow[t]{3}{*}{$\begin{array}{l}\text { Hot Caustic } \\
\text { Leach }\end{array}$} & \multirow{2}{*}{\multicolumn{2}{|c|}{$\begin{array}{c}2^{\text {nd }} \text { set of } 20.01 \mathrm{M} \mathrm{NaOH} \\
\text { washes after Hot Caustic } \\
\text { Leach Treatment }\end{array}$}} \\
\hline & \multicolumn{3}{|c|}{ Wash Number } & & & \\
\hline & 1 & 2 & 3 & & 4 & 5 \\
\hline $\mathrm{Ag}$ & 5 & 3 & 2 & $<3$ & $<1$ & $<1$ \\
\hline $\mathrm{Al}$ & 473 & 287 & 173 & 3,525 & 1,113 & 237 \\
\hline $\mathrm{Ba}$ & $<1$ & $<1$ & $<1$ & $<1$ & $<1$ & $<1$ \\
\hline $\mathrm{Be}$ & $<1$ & $<1$ & $<1$ & $<1$ & $<1$ & $<1$ \\
\hline $\mathrm{Ca}$ & $<1$ & $<1$ & $<1$ & $<1$ & $<1$ & $<1$ \\
\hline $\mathrm{Cd}$ & $<1$ & $<1$ & $<1$ & $<1$ & $<1$ & $<1$ \\
\hline $\mathrm{Cr}$ & 14 & 8 & 5 & 24 & 11 & 2 \\
\hline $\mathrm{Fe}$ & 6 & 6 & 8 & 2 & 4 & 5 \\
\hline $\mathrm{Li}$ & $<2$ & $<2$ & $<2$ & 12 & 3 & $<2$ \\
\hline $\mathrm{Mg}$ & $<1$ & $<1$ & $<1$ & $<1$ & $<1$ & $<1$ \\
\hline $\mathrm{Mn}$ & 1 & $<1$ & $<1$ & $<1$ & $<1$ & $<1$ \\
\hline $\mathrm{Na}$ & 9,030 & 5,200 & 3,100 & 54,000 & 14,500 & 2,100 \\
\hline $\mathrm{Ni}$ & $<1$ & $<1$ & $<1$ & $<1$ & $<1$ & $<1$ \\
\hline$P$ & 174 & 97 & 55 & 137 & 37 & 10 \\
\hline $\mathrm{Pb}$ & $<5$ & $<5$ & $<5$ & 3 & $<5$ & $<5$ \\
\hline $\mathrm{S}$ & 94 & 55 & 31 & 12 & 7 & 4 \\
\hline $\mathrm{Si}$ & 14 & 8 & 6 & 130 & 79 & 67 \\
\hline $\mathrm{Sr}$ & $<1$ & $<1$ & $<1$ & $<1$ & $<1$ & $<1$ \\
\hline $\mathrm{Ti}$ & $<2$ & $<2$ & $<2$ & $<2$ & $<2$ & $<2$ \\
\hline $\bar{U}$ & $<5$ & $<5$ & $<5$ & 30 & 11 & $<5$ \\
\hline $\mathrm{Zn}$ & $<2$ & $<2$ & $<2$ & $<2$ & $<2$ & $<2$ \\
\hline $\mathrm{Zr}$ & $<2$ & $<2$ & $<2$ & $<2$ & $<2$ & $<2$ \\
\hline
\end{tabular}


Table 9-8. Elemental and Anion Composition of the Five 0.01 M NaOH Washes and the Hot Caustic Leach Solution of the Specification 12 Leach Procedure page 2 of 2

All Concentrations in $\mathrm{mg} / \mathrm{kg}$

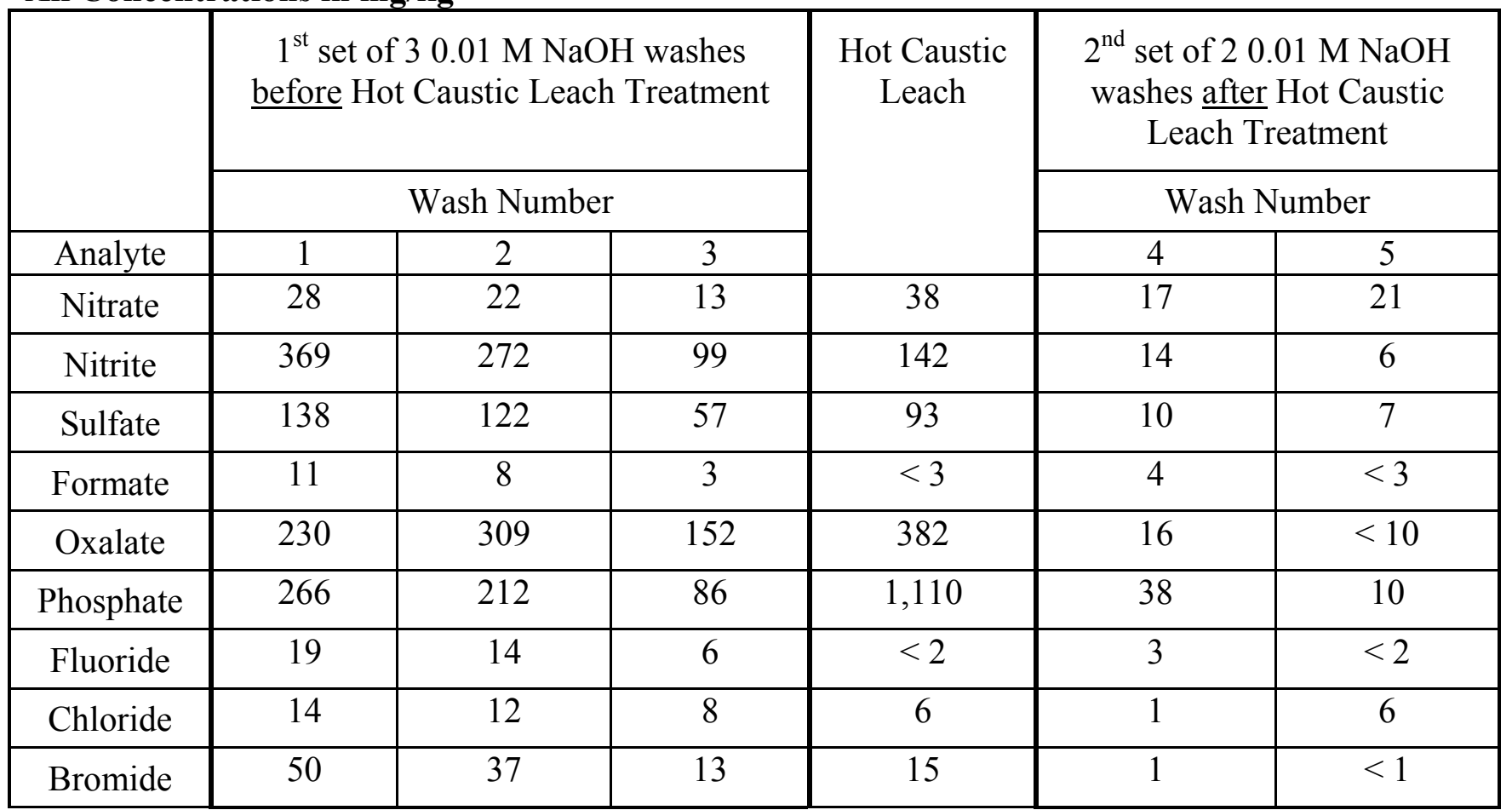

\subsection{ELEMENTAL ANALYSIS OF THE RESIDUAL SOLIDS AFTER THE SPECIFICATION 12 LEACH PROCEDURE}

The effect of spilling some of the Trial 1 digestion of the residual solids after the Specification 12 Leach Procedure during the work up is clearly seen in the elemental analysis data in

Table 9-9. The Trial 1 digestion elemental analyses are biased low on all analytes by 15-20\%. The relative ratio of important elements such as Fe and Al agree well in the two trials, however, indicating that the actual Specification 12 Leach Procedure was carried out with good precision in the two trials. 
Table 9-9. Elemental Analysis of the Residual Wet Solids after the Specification 12 Leach Procedure

All Elemental Determinations by ICP-AES

\begin{tabular}{|c|c|c|}
\hline Analyte & $\begin{array}{l}\text { Trial } 1 \text { Analysis on Residual Wet } \\
\text { Solids Following Specification } 12 \\
\text { Leach Procedure (mg/kg) }\end{array}$ & $\begin{array}{c}\text { Trial } 2 \text { Analysis on Residual Wet } \\
\text { Solids Following Specification } 12 \\
\text { Leach Procedure (mg/kg) }\end{array}$ \\
\hline $\mathrm{Ag}$ & 126 & 124 \\
\hline $\mathrm{Al}$ & 25,600 & 31,200 \\
\hline $\mathrm{Ba}$ & 603 & 727 \\
\hline $\mathrm{Be}$ & 4 & 3 \\
\hline $\mathrm{Ca}$ & 3,460 & 4,180 \\
\hline $\mathrm{Cd}$ & 115 & 140 \\
\hline $\mathrm{Cr}$ & 375 & 1,780 \\
\hline $\mathrm{Cr}$ & 1,420 & 1,700 \\
\hline $\mathrm{Fe}$ & 99,600 & 115,000 \\
\hline $\mathrm{Li}$ & 257 & 312 \\
\hline $\mathrm{Mg}$ & 905 & 1,090 \\
\hline $\mathrm{Mn}$ & 21,200 & 24,700 \\
\hline $\mathrm{Na}$ & 28,200 & 37,100 \\
\hline $\mathrm{Ni}$ & 3,300 & 3,860 \\
\hline $\mathrm{P}$ & 2,160 & 2,560 \\
\hline $\mathrm{Pb}$ & 4,770 & 5,560 \\
\hline $\mathrm{S}$ & 501 & 640 \\
\hline $\mathrm{Si}$ & N/A- HF causes high bias & N/A- HF causes high bias \\
\hline $\mathrm{Sr}$ & 888 & 1,090 \\
\hline $\mathrm{Ti}$ & 176 & 221 \\
\hline $\mathrm{Zn}$ & 146 & 170 \\
\hline $\mathrm{Zr}$ & 3,230 & 3,940 \\
\hline
\end{tabular}

Note: A small amount of liquid was spilled in the work-up of the Trial 1 digestion. The effect on the elemental analysis is obvious from comparison of the Trial 1 and Trial 2 results. Only the results from Trial 2 were used to compare wash/leach procedures. 


\subsection{COMPARISON OF ELEMENTAL ANALYSIS OF THE UNWASHED WET AY-102/C-106 SOLIDS WITH THE RESIDUAL WET SOLIDS AFTER THREE PRETREATMENT PROCEDURES}

\section{Procedures: \\ 0.01 M NaOH Wash Procedure \\ Plant Leach Procedure \\ Specification 12 Leach Procedure}

The reasons for performing these washing/leaching experiments were to determine:

(1) Is a hot caustic leach protocol indicated for AY-102/C-106?

(2) Does the Specification 12 Leach Procedure produce essentially the same wet solids residue as the Plant Leach Procedure?

(3) What is the composition of wash and leach solutions?

Table 9-10 compares the elemental analyses of the as-received (unwashed) wet solids with the residue from the $0.01 \mathrm{M} \mathrm{NaOH}$ Wash, the Plant Leach Procedure, and the Specification 12 Leach Procedure. The elemental analysis data for the unwashed solids were taken from Table 7-15, our "preferred" analysis based on selecting the data from three sets of digestions and elemental analyses. The $0.01 \mathrm{M} \mathrm{NaOH}$ wash data is the average of four determinations since the precision of these four separate washes and analyses was good. Because of the large volume of AY-102/C-106 slurry used for both the Plant Leach Procedure and the Specification 12 Leach Procedure, only replicate determinations were performed. In both cases, we suffered an accident in one of the replicate workups that lost some of the sample and corrupted the analytical data for this trial. Therefore, in Table 9-10, only the "Selected" or best replicate determination was used for the Plant Leach Procedure and Specification 12 Leach Procedure in the comparison.

The elemental analysis data in Table $9-10$ is on a wet solids basis. Therefore, the elemental concentrations depend on the amount of interstitial water associated with the solids. Although we were able to minimize the analytical spread caused by variations in the interstitial water, a better way to evaluate the effect of the wash/leach procedure is to consider the ratio of elements rather than the absolute concentrations. In the table we show some ratios of elements that could be affected by the wash/leach procedures $(\mathrm{Al} / \mathrm{Fe}, \mathrm{Na} / \mathrm{Fe}, \mathrm{Na} / \mathrm{Al})$ as well as the $\mathrm{Fe} / \mathrm{Mn}$ ratio expected to be relatively unchanged by these procedures. The Fe/Al ratio is of particular interest since this ratio shows the effectiveness of the caustic leach procedures for removing $\mathrm{Al}$ from the $\mathrm{AY}-102 / \mathrm{C}-106$ sludge. Fe is insoluble in hot $3 \mathrm{M} \mathrm{NaOH}$ whereas aluminum hydroxide in the solid fraction dissolves in hot caustic. Comparison of the $\mathrm{Fe} / \mathrm{Al}$ ratios shows that the $0.01 \mathrm{M} \mathrm{NaOH}$ wash has minimal effect on the $\mathrm{Al}$ concentration. The hot caustic leach of the Plant Leach Procedure and Specification 12 Leach Procedure significantly reduces the $\mathrm{Al}$ in the solids, as shown by a much larger Fe/Al ratio. Minimal differences in $\mathrm{Fe} / \mathrm{Al}$ ratios were observed between the Plant Leach and Specification 12 Leach Procedures, suggesting at least in these admittedly limited experiments that they are equally effective for dissolving $\mathrm{Al}$ in the solid fraction. 
Table 9-10. Comparison of Elemental Analysis of the Unwashed Wet AY-102/C-106 Solids with the Residual Wet Solids after Three Pretreatment Procedures 0.01 M NaOH Wash Procedure; Plant Leach Procedure; and Specification 12 Leach Procedure

\begin{tabular}{|c|c|c|c|c|}
\hline Analyte & $\begin{array}{c}\text { Average } \\
\text { Analysis On } \\
\text { Unwashed Wet } \\
\text { Solids (From } \\
\text { Table 7.15) } \\
\text { (mg/kg) }\end{array}$ & $\begin{array}{c}\text { Average Analysis } \\
\text { On Residual Wet } \\
\text { Solids Following } \\
\text { 0.01 M NaOH } \\
\text { Wash } \\
\text { (mg/kg) }\end{array}$ & $\begin{array}{l}\text { Selected Analysis } \\
\text { On Residual Wet } \\
\text { Solids Following } \\
\text { Plant Leach } \\
\text { Procedure } \\
\text { (mg/kg) }\end{array}$ & $\begin{array}{c}\text { Selected } \\
\text { Analysis On } \\
\text { Residual Wet } \\
\text { Solids } \\
\text { Following } \\
\text { Spec. 12 Leach } \\
\text { Procedure } \\
\text { (mg/kg) }\end{array}$ \\
\hline $\mathrm{Ag}$ & 1,290 & 318 & 238 & 124 \\
\hline $\mathrm{Al}$ & 32,300 & 36,600 & 30,800 & 31,200 \\
\hline $\mathrm{Ba}$ & 500 & 451 & 570 & 727 \\
\hline $\mathrm{Be}$ & $<1$ & $<1$ & $<1$ & 2.9 \\
\hline $\mathrm{Ca}$ & 2,500 & 3,125 & 4,340 & 4,180 \\
\hline $\mathrm{Cd}$ & 100 & 92 & 115 & 140 \\
\hline $\mathrm{Cr}$ & 1,290 & 1,300 & 1,780 & 1,700 \\
\hline $\mathrm{Fe}$ & 72,900 & 77,100 & 122,000 & 115,000 \\
\hline $\mathrm{Li}$ & 215 & 219 & 233 & 312 \\
\hline $\mathrm{Mg}$ & 670 & 800 & 997 & 1,090 \\
\hline $\mathrm{Mn}$ & 15,600 & 16,300 & 25,800 & 24,700 \\
\hline $\mathrm{Na}$ & 75,300 & 35,250 & 40,600 & 37,100 \\
\hline $\mathrm{Ni}$ & 2,410 & 2,550 & 3,980 & 3,860 \\
\hline $\mathrm{P}$ & 3,100 & 1,960 & 2,420 & 2,560 \\
\hline $\mathrm{Pb}$ & 3,260 & 3,500 & 5,880 & 5,560 \\
\hline$S$ & 830 & 673 & 605 & 640 \\
\hline $\mathrm{Si}$ & 20,600 & $\begin{array}{c}\text { N/A HF causes high } \\
\text { bias }\end{array}$ & $\begin{array}{l}\text { N/A- HF causes high } \\
\text { bias }\end{array}$ & $\begin{array}{l}\text { N/A- HF causes } \\
\text { high bias }\end{array}$ \\
\hline $\mathrm{Sr}$ & 600 & 815 & 990 & 1,090 \\
\hline $\mathrm{Ti}$ & 143 & 160 & 149 & 221 \\
\hline $\mathrm{Zn}$ & 199 & 58 & 278 & 170 \\
\hline $\mathrm{Zr}$ & 2,570 & 2,580 & 3,220 & 3,940 \\
\hline
\end{tabular}


Table 9-10. Comparison of Elemental Analysis of the Unwashed Wet AY-102/C-106 Solids with the Residual Wet Solids after Three Pretreatment Procedures Inhibited Water Wash Procedure; Plant Leach Procedure; and Specification 12 Leach Procedure - page 2 of 2

\begin{tabular}{|c|c|c|c|c|}
\hline Analyte & $\begin{array}{c}\text { Average } \\
\text { Analysis On } \\
\text { Unwashed Wet } \\
\text { Solids (From } \\
\text { Table 7.15) } \\
\text { (mg/kg) }\end{array}$ & $\begin{array}{c}\text { Average Analysis } \\
\text { On Residual Wet } \\
\text { Solids Following } \\
\text { 0.01 M NaOH } \\
\text { Wash } \\
(\mathrm{mg} / \mathrm{kg})\end{array}$ & $\begin{array}{c}\text { Selected Analysis } \\
\text { On Residual Wet } \\
\text { Solids Following } \\
\text { Plant Leach } \\
\text { Procedure } \\
\text { (mg/kg) }\end{array}$ & $\begin{array}{c}\text { Selected } \\
\text { Analysis On } \\
\text { Residual Wet } \\
\text { Solids } \\
\text { Following } \\
\text { Spec. 12 Leach } \\
\text { Procedure } \\
\text { (mg/kg) } \\
\end{array}$ \\
\hline \multicolumn{5}{|c|}{ Ratios of Elements Potentially Affected by Wash/Leach Procedures } \\
\hline & $\begin{array}{c}\text { Unwashed } \\
\text { AY-102/C-106 }\end{array}$ & $0,01 \mathrm{M} \mathrm{NaOH}$ Wash & $\begin{array}{l}\text { Plant Leach } \\
\text { Procedure }\end{array}$ & $\begin{array}{l}\text { Spec. } 12 \text { Leach } \\
\text { Procedure }\end{array}$ \\
\hline $\mathrm{Fe} / \mathrm{Al}$ ratio & 2.24 & 2.10 & 3.96 & 3.73 \\
\hline $\mathrm{Fe} / \mathrm{Na}$ ratio & 0.97 & 2.19 & 3.00 & 3.10 \\
\hline $\mathrm{Na} / \mathrm{Al}$ ratio & 2.33 & 0.97 & 1.32 & 1.19 \\
\hline $\mathrm{Fe} / \mathrm{Mn}$ ratio & 4.67 & 4.73 & 4.73 & 4.66 \\
\hline
\end{tabular}

\subsection{SUMMARY OF RESULTS OF WASH/LEACH PROCEDURE TESTS}

The limited amount of AY-102/C-106 slurry available for testing the wash/leach procedures was the primary technical concern in performing these experiments. We would have preferred to scale up the volume of sludge used in the experiments and also to perform more replicates to produce statistically defensible data. However, the limited data obtained is consistent with our experiences with treating high-level sludge. The data and observations from these experiments are consistent with the following conclusions:

- The Plant Leach Procedure and Specification 12 Leach Procedure both significantly reduce the amount of $\mathrm{Al}$ in the washed $\mathrm{AY}-102 / \mathrm{C}-106$ solid fraction compared with Fe. The $\mathrm{Al}$ reduction resulting from the wash/leach procedures was manifested by changes in the Fe/Al elemental ratio as compared with the unwashed sludge and with the sludge washed only with $0.01 \mathrm{M} \mathrm{NaOH}$.

Unwashed AY-102/C-106 sludge

Residue after $0.01 \mathrm{M} \mathrm{NaOH}$ Wash

Residue after Plant Leach Procedure

Residue after Specification 12 Leach Procedure
$\mathrm{Fe} / \mathrm{Al}=2.24$

$\mathrm{Fe} / \mathrm{Al}=2.10$

$\mathrm{Fe} / \mathrm{Al}=3.96$

$\mathrm{Fe} / \mathrm{Al}=3.73$ 
- The hot caustic leach step (used in both the Plant Leach Procedure and the Specification 12 Leach Procedure) dissolves Al compounds that are not being removed by the simple $0.01 \mathrm{M} \mathrm{NaOH}$ wash steps of the procedures. Since the Plant Leach Procedure and Specification 12 Leach Procedure removed no significant quantity of $\mathrm{Fe}$, the approximate amount of Al removed from these procedures was $43 \%$ for the Plant Leach Procedure and $40 \%$ for the Specification 12 Leach Procedure.

- The Plant Leach Procedure and the Specification 12 Leach Procedure produced essentially the same solid residue as determined by elemental analysis.

- The Specification 12 Leach Procedure is much easier to perform in a shielded cell environment by nature of the fewer $0.01 \mathrm{M} \mathrm{NaOH}$ washes and the larger volume of these washes.

- Analyses of the wash solutions from all three wash/leach procedures were mainly consistent with expectations based on simple dilutions of the interstitial supernatant in the unwashed AY-102/C-106 solid fraction.

Note: Preliminary results of these tests were forwarded to Pretreatment Group of the Research and Technology section of the Waste Treatment Plant. Based on the results of these wash/leach procedure tests, the Pretreatment Group directed SRTC to use a modified Plant Leach Procedure to prepare the AY-102/C-106 solids for Cells Unit Filter tests. 


\section{APPENDIX A - TANK AY-102 CORE SAMPLES}

\section{Letter of Instruction, Internal Memo \#8G000-CMS-01-017}

Note: Grammatical changes have been made to this memo. Content has not been changed.

$\begin{array}{llll}\text { To: } & \text { D. B. Hardy } & \text { S3-30 } & \text { Date: June 20,2001 } \\ \text { From: } & \begin{array}{l}\text { C. M. Seidel } \\ \text { (Original signed by CMS) }\end{array} & \text { G1-32 } & \text { Telephone: 373-5211 } \\ \text { cc: } & & \\ & \text { T. A. Brown } & \text { T6-14 } & \\ \text { R. L. Clawson } & \text { H1-11 } & \\ \text { R. K. Fuller } & \text { T6-12 } & \\ \text { D. J. Hart } & \text { T6-14 } & \\ \text { E. D. Lee } & \text { Sigma IV } & \\ \text { R. L. Myers } & \text { P7-28 } & \\ \text { T. R. Pauly } & \text { S7-70 } & \\ \text { J. R. Prilucik } & \text { T6-12 } & \\ \text { J. H. Rasmussen } & \text { R2-12 } & \\ \text { G. A. Stanton } & \text { S7-70 } & \\ \text { W. I. Winters } & \text { T6-07 } & \end{array}$

Subject: $\quad$ SHIPMENT OF AY-102 TO THE SAVANNAH RIVER TECHNOLOGY CENTER

Reference:

(1) Internal Memo, C. M. Seidel to D. J. Hart, "Archive Requirements for Tanks 241-AY102 and 241-SY-102," 8G000-CMS-01-013, dated April 30, 2001.

(2) Internal Memo, C. M. Seidel to D. J. Hart, "Shipments to SRTC," 8G000-CMS-01-012, dated April 12, 2001.

Analytical Services has been instructed to ship 241-AY-102 core 289 and 290 samples from archive storage at the 222-S Laboratory to the Savannah River Technology Center (SRTC). A review of the DOT PAS-1 cask shipping requirements has determined that blending the material would be required to ensure each sample is within the concentration limits for the casks. The samples are to be blended as outlined below and shipped using the PAS-1 casks in $500 \mathrm{~mL}$ bottles to SRTC. The shipping address and receiver instructions are defined in Reference 1 above. R. L. Clawson of Duratek Federal Services, Northwest Operations has appointed John O'Brien as his representative to act as the certified shipper for this activity. 
The U.S. Department of Energy, Office of River Protection (ORP) has directed CH2M HILL Hanford Group, Inc. (CHG) to deliver this material in FY 2001. Bechtel National, Inc. (BNI) and ORP has instructed SRTC to use this material to conduct "Process Verification and Waste Form Qualification" testing. It has been determined that only sample material taken from AY-102 after the last caustic adjustment is to be used in the "Process Verification and Waste Form Qualification" testing at SRTC. This requirement limits the material to be shipped to samples taken after February 14, 2001.

Retrieval of this material from archive, compositing, and packaging for shipment is to be charged directly to the Tank Characterization Core sample analysis account at 222-S.

The AY-102 sample material is to be packaged as follows:

In Bottles 1 through $7 *$ :

To each bottle add 110 grams (73-74cc) of solids from core 289 or 290 and $375 \mathrm{~mL}$ of liquids from core 289 or 290 . Use Samples from Table 1 below for this activity. This shall result in an estimated volume of 447 to $450 \mathrm{~mL}$ per bottle. Record the mass or volume and origin of the material added to each bottle.

In Bottles 8 through 10*:

To each bottle add 110 grams (73-74cc) of soils from core 289 or 290 and $375 \mathrm{~mL}$ of liquids from samples from table 2 and any remaining liquids from table 1 samples. This shall result in an estimated volume of 447 to $450 \mathrm{~mL}$ per bottle. Record the mass or volume and origin of the material added to each bottle.

Report the weight and visual observations to Client Services as required in section 3.4 of Letter of Instruction (LOI) 8G000-CMS-01-013 (Reference 2) along with the documented composition of each bottle shipped as required here to Client Services. Client Services will prepare and report this information to BNI.

*Compositing the identified liquid supernate prior to packaging these samples for shipment is acceptable. 
Table 1: Archive Samples Taken for ICD-23

\begin{tabular}{|c|c|c|c|c|c|c|}
\hline Tank & $\begin{array}{c}\text { Core } \\
\#\end{array}$ & Segment & Matrix & $\begin{array}{l}\text { Estimated } \\
\text { liquid mass } \\
\text { (grams)** }\end{array}$ & $\begin{array}{l}\text { Estimated Wet } \\
\text { Solids mass } \\
\text { (grams)** }\end{array}$ & Date Sampled \\
\hline AY -102 & 289 & 1 & Liquid & 231.3 & & March 9, 2001 \\
\hline AY-102 & 289 & 2 & Liquid & 332.2 & & March 9, 2001 \\
\hline AY-102 & 289 & 3 & Liquid & 333.8 & & March 9, 2001 \\
\hline AY-102 & 289 & 4 & Liquid & 346.3 & & March 14, 2001 \\
\hline AY-102 & 289 & 5 & Liquid & 274.1 & & March 14, 2001 \\
\hline AY-102 & 289 & 6 & Liquid & 343.9 & & March 15, 2001 \\
\hline AY-102 & 289 & 7 & Liquid & 309.4 & & March 19, 2001 \\
\hline AY-102 & 289 & 8 & Liquid & 344.3 & & March 20, 2001 \\
\hline AY-102 & 289 & 9 & Liquid & 339.8 & & March 20, 2001 \\
\hline AY-102 & 289 & 10 & Liquid & 197.2 & 151.1 & March 20, 2001 \\
\hline AY-102 & 289 & 11 & Sludge & & 396.3 & March 20, 2001 \\
\hline AY-102 & 289 & 12 & Sludge & & 416.0 & March 20, 2001 \\
\hline AY-102 & 289 & 13 & Sludge & & 341.4 & March 20, 2001 \\
\hline AY-102 & 290 & $12 \mathrm{RA}$ & Sludge & & 217.1 & March 26, 2001 \\
\hline AY-102 & 290 & $12 \mathrm{RB}$ & Sludge & & 58.5 & March 26, 2001 \\
\hline
\end{tabular}

** Weights are estimated at time of extrusion. Sample transfers and repackaging resuls in some loss of material.

Table 2: Material Sampled for Other Programmatic Needs - Available for ICD-23 Support

\begin{tabular}{|c|c|c|c|c|c|c|c|}
\hline Tank & $\begin{array}{c}\text { Core } \\
\#\end{array}$ & Segment & Matrix & $\begin{array}{l}\text { Estimated } \\
\text { liquid mass } \\
\text { (grams)** }\end{array}$ & $\begin{array}{c}\text { Estimated } \\
\text { Wet Solids } \\
\text { mass } \\
\text { (grams)** }\end{array}$ & $\begin{array}{c}\text { Estimated } \\
\text { liquid } \\
\text { available for } \\
\text { ICD-23 (g) }\end{array}$ & Date Sampled \\
\hline AY-102 & 290 & 1 & Liquid & 323.1 & & 282.2 & March 22, 2001 \\
\hline AY-102 & 290 & 5 & Liquid & 346.5 & & 305.8 & March 22, 2001 \\
\hline AY-102 & 290 & 9 & Liquid & 273.0 & 95.9 & 213.1 & March 22, 2001 \\
\hline AY-102 & 290 & 10 & Sludge & 16.2 & 327.0 & 16.2 & March 22, 2001 \\
\hline AY-102 & 290 & 11 & Sludge & & 415.2 & 43.1 & March 23, 2001 \\
\hline AY-102 & 290 & $12 \mathrm{~A}$ & Sludge & & 284.4 & & March 23, 2001 \\
\hline AY-102 & 290 & $12 \mathrm{~B}$ & Sludge & & 6.5 & & March 23, 2001 \\
\hline $\begin{array}{c}\text { Grab } \\
\text { Sample }\end{array}$ & & & & & & 57.8 & Lab Composite \\
\hline $2 \mathrm{AY}-01-05$ & & & & 156.8 & & 116.1 & March 23, 2001 \\
\hline 2AY-01-06 & & & & 156.0 & & 116.0 & March 23, 2001 \\
\hline 2AY-01-07 & & & & 152.9 & & 111.0 & March 23, 2001 \\
\hline 2AY-01-08 & & & & 37 & 160 & & March 23, 2001 \\
\hline
\end{tabular}


Points of Contact:

\begin{tabular}{|l|l|l|l|}
\hline \multicolumn{1}{|c|}{ Responsibility } & \multicolumn{1}{c|}{ Organization } & \multicolumn{1}{c|}{ Contact } & \multicolumn{1}{c|}{ Phone } \\
\hline Project Lead & AS, Client Services (FH) & C. M. Seidel & $373-5211$ \\
\hline Tank Coordinator & RPP (CHG) Process Engineering & J. H. Rasmussen & $373-1128$ \\
\hline 222-S Operations & AS, 222-S Operations (FH) & T. A. Brown & $372-0049$ \\
\hline 222-S Hot Cells & AS, 222-S Hot Cell Operations (FH) & R. Akita & $373-2815$ \\
\hline Certified Shipper & Transportation Services (DFSNW) & J. H. O'Brien & $376-7154$ \\
\hline SRTC Sample Receipt & $\begin{array}{l}\text { Chemical Separation and Slurry } \\
\text { Process Group (PNNL) }\end{array}$ & D. Fields & $803-725-$ \\
& & & 7097 \\
\hline
\end{tabular}

All applicable DOE contractual Environmental Safety and Health requirements, sample handling, and transportation shall be performed per approved procedures or work packages. All DOE contractual and Contractor facility safety requirements apply to this work scope. No additional safety requirements are imposed by this LOI.

mor

CONCURRENCE:

Original signed by EDL

Ernest D. Lee, Lead Engineer

R\&T Characterization

Bechtel National, Inc.

Approved by GAS via telecon

George A. Stanton, Jr., Program Manager

Fluor Hanford

P. O. Box 1000

Richland, WA 99352 


\section{APPENDIX B - \\ AY-102 “AS-RECEIVED” SHIELDED CELLS RHEOLOGY RESULTS}

Note: Grammatical changes have been made to this memo. Content has not been changed.

SRT-RPP-2002-00229, Rev. 0

PAGE 1 OF 10

FEBRUARY 6, 2003

To: $\quad$ Charles Coleman, SRTC

CC: David Crowley, SRTC

Sharon Marra, SRTC

Jim Marra, SRTC

Kim Howard, SRTC - File

From: Erich Hansen, SRTC

Terri Fellinger, SRTC

\section{AY-102 “As-Received” Shielded Cells Rheology Results}

\section{Summary}

The AY-102 "as-received" radioactive slurry sample contained $21.2 \%$ total solids, $5.85 \%$ insoluble solids ${ }^{1}$ and had a density of $1.2 \mathrm{~g} / \mathrm{mL}^{1}$. Rheological (flow curves) and settled shear strength properties at $25^{\circ} \mathrm{C}$ and $40{ }^{\circ} \mathrm{C}$ were measured in the SRTC Shielded Cells. Based on visual observations of the "as-received" AY-102 sample, the samples did not appear to contain any yield stress. The average viscosity results obtained from the flow curves are shown in Table 1. The viscosities in Table 1 varied as expected (i.e. lower temperature higher viscosity, higher temperature lower viscosity) based on the temperature at which the samples were measured.

Table 1: Viscosity Results of "as-received" AY-102 Sludge Sample

\begin{tabular}{|c|c|}
\hline $\begin{array}{c}\text { Temperature } \\
\left({ }^{\circ} \mathrm{C}\right)\end{array}$ & $\begin{array}{c}\text { Average Viscosity } \\
(\mathrm{cP})\end{array}$ \\
\hline 25 & 4.3 \\
\hline 40 & 3.1 \\
\hline
\end{tabular}

\footnotetext{
${ }^{1}$ Coleman, Chuck, email "Density of AY-102", 8/22/02
} 
The settled shear strength properties were measured for the "as received" sludge sample. The sample was allowed to settle undisturbed for at least 48 hours prior to measurements at $40{ }^{\circ} \mathrm{C}$ and $25{ }^{\circ} \mathrm{C}$. The shear strength was measured using vane geometry. There was no response from the instrument for the $40{ }^{\circ} \mathrm{C}$ measurements. For the $25{ }^{\circ} \mathrm{C}$ measurements, a maximum of $43 \mathrm{~Pa}$ (or 430 dynes $/ \mathrm{cm}^{2}$ ) was measured in one run and the other two runs indicated no yield stress. The results from this one run are not consistent of vane measurement results of materials with shear strength. Visual observation of the vane after shear strength measurement and cleanup of the settled solids out of the settling cups also indicated that there was little to no yield stress in this settled sludge. Results and visual observations indicate this sludge does not have any measurable settled solids shear strength at the measured temperatures.

\section{Discussion}

A sample of "as-received" radioactive AY-102 sludge was provided to Interim Waste Technology (IWT) by Analytical Developmental Section (ADS) for rheological characterization. The AY-102 "as-received" radioactive slurry sample contained $21.2 \%$ total solids, $5.85 \%$ insoluble solids ${ }^{1}$ and had a density of $1.2 \mathrm{~g} / \mathrm{mL}^{1}$. Visual observation of the "asreceived" sludge sample indicated that it does not contain any yield stress properties, material did not stick to the sides of the sample bottle, was very fluid and the solids easily suspended. The rheological characterization included flow curve and settled shear strength measurements, to be performed at $25^{\circ} \mathrm{C}$ and $40^{\circ} \mathrm{C}$ using the Haake RV30/M5 rheometer located in the Savannah River Technology Center (SRTC) shielded cells. The rheological characterizations are based on the methods outlined by River Protection Project - Waste Treatment Plant (RPPWTP R\&T $)^{2}$. The concentric MVI measuring head was used to measure the flow curves and a vane measuring head was used to measure the settled shear strength. Visual inspection of these measuring heads indicated there was no physical damage to the measuring surfaces.

Table 2 summarizes the flow curve program, physical dimensions and calculated constants used in the Haake software for the MVI head. The output from the Haake software was not corrected for non-Newtonian behavior, slip, etc. The flow curve data obtained using the MVI was analyzed using the statistical package in Microsoft Excel to determine the slope, intercept and coefficient of determination $\left(\mathrm{R}^{2}\right)$. The resulting flow curves are attached in an excel spreadsheet called "Radioactive AY-102, As-received FLOW CURVES," in the email that accompanies this document.

Prior to loading a sample, the MVI head is first secured to the M5 torque package through the heating jacket. The sample is homogenized and loaded into the MV cup, the cup raised into the MVI head and secured in the heating jacket. Prior to starting the measurement, the shear stress as measured by the RV30 was set to zero. Triplicate measurements were made for each temperature and the above action was performed in all the measurements. Due to the unusual flow curves (a shear stress off-set) for an expected Newtonian fluid, it was decided to fit the linear part of the curve, using a linear fit (also known as a Bingham Plastic) as shown in equation [1] to all data sets. This shear stress off-set impacts thinner rheological fluids as compared to thicker rheological fluids, since this off-set behaves like a yield stress, yielding higher apparent viscosities at the lower shear rate ranges. The slope of the linear fit will be

2 24590-WTP-GPG-RTD-001, “Guidelines for Performing Chemical, Physical and Rheological Properties Measurements”, Rev. 0, 5/20/02 
reported as the viscosity of the fluid. The NIST standard data sets were also fitted using a Newtonian fluid model (equation [2]). The shear rate range in which the standard and samples were fitted to equations [1] and [2] are described in the appropriate sections. Measurements were performed at both $25^{\circ} \mathrm{C}$ and $40^{\circ} \mathrm{C}$.

$$
\begin{aligned}
\tau & =\tau_{o f f}+\frac{\mu \cdot \dot{\gamma}}{1000} \\
\tau & =\frac{\mu \cdot \dot{\gamma}}{1000}
\end{aligned}
$$

where: $\tau=$ Haake measured shear stress $(\mathrm{Pa})$

$\tau_{\text {off }}=$ shear stress off-set $(\mathrm{Pa})$

$\tau=$ viscosity $(\mathrm{cP}$ - centipoise)

$\dot{\gamma}=$ Haake measured shear rate $\left(\mathrm{sec}^{-1}\right)$

Table 2: MV1 Flow Curve Program, Physical Dimensions and Constants

\begin{tabular}{|l|l|l|}
\hline \multicolumn{1}{|c|}{ Materials } & Flow Curve Program for both i and ii & $\begin{array}{l}\text { Physical Dimensions and } \\
\text { Constants }\end{array}$ \\
\hline i: NIST Oil & $\begin{array}{l}\text { Shear ramp up } 0-1100 \mathrm{sec}^{-1}, 5 \\
\text { standard }\end{array}$ & $\begin{array}{l}\text { Bob height: } 0.060 \mathrm{~m} \\
\text { Binutes }\end{array}$ \\
ii: samples & $\begin{array}{l}\text { Hold shear } 1100 \mathrm{sec}^{-1}, 2 \text { minutes } \\
\text { shear ramp down } 1100-0 \mathrm{sec}^{-1}, 5\end{array}$ & $\begin{array}{l}\text { Cup (outside) radius:0.02004 } \mathrm{m} \\
\text { minutes }\end{array}$ \\
\hline
\end{tabular}

Table 3 summarizes the shear strength program, physical dimensions of the vane and cup and constants used in the Haake software for the vane head. The results obtained from the rheometer were then corrected for the proper shear strength by multiplying by the correct Afactor. The speed of the vane was determined by visually counting the number of revolutions per minute that would yield $0.3 \mathrm{RPM}^{2}$ prior to any measurement. The settled shear strength results are attached in an excel spreadsheet called "Radioactive AY-102, Vane measurement," in the email that accompanies this document.

Table 3: Vane Program, Physical Dimensions and Constants

\begin{tabular}{|c|c|l|}
\hline Materials & Vane Program & $\begin{array}{l}\text { Physical Dimensions and } \\
\text { Constants }\end{array}$ \\
\hline \multirow{3}{*}{ Samples } & Rotational Rate: 0.3 & Vane Height: $0.01588 \mathrm{~m}$ \\
& RPM & Vane Radius: $0.01588 \mathrm{~m}$ \\
& Time: 5 minutes & Cup Radius: $0.0397 \mathrm{~m}$ \\
& A maximum) & A factor: $1.0 \mathrm{~Pa} / \% \tau$ \\
& & M- factor: $1.0 \mathrm{~s}^{-1} / \% \mathrm{D}$ \\
\hline
\end{tabular}


During the vane measurements, the settled sample was transferred to a Teflon sample cup with a diameter as stated in Table 3. The cup was loaded with the minimum settled volume to satisfy the requirements of 24590-WTP-GPG-RTD-001, given the geometry of the vane and cup. The sample was allowed to sit undistributed for at least 48 hours between measurements at both $25^{\circ} \mathrm{C}$ and $40^{\circ} \mathrm{C}$.

\section{Flow Curve Measurements:}

\section{Oil Standard:}

Per the methods outlined in RPP-WTP- R\&T, there is a requirement to functionally check the operability of the RV30/M5 rheometer using a NIST (National Institute of Standards and Technology) traceable viscosity standard. The oil standard was run in triplicate. The results are given in Table 4 for a measuring temperature of $29.2^{\circ} \mathrm{C}$. The complete flow curves were fitted with equations [1] and [2]. The results, when fitted with equation [1], an offset between 0.8 to $1.44 \mathrm{~Pa}$ were calculated. This off-set is evident in Figure 1, which is a typical flow curve obtained from the oil standard. Since the oil standard is Newtonian, the data should have been a straight line with no intercept. A complete flow curve of the same data is shown in Figure 2, which shows that equations [1] and [2] fit the data well. The slope of the linear fit (from equation [1]) and the Newtonian fit (from equation [2]) were all within \pm 10 percent of the NIST oil standard viscosity, which was $25.1 \mathrm{cP}$. The linearly fitted data has a slightly higher $\mathrm{R}^{2}$ value than that of the Newtonian fit. This is expected, since the linear model has one additional variable for fitting and the data shows an off-set. Table 5 provides details of the oil standard. All the NIST standard flow curves are in the "Radioactive AY-102, As-received FLOW CURVES" spreadsheet.

Table 4: RV30/M5 Functional Checks Using MVI

\begin{tabular}{|c|c|c|c|c|c|c|c|}
\hline \multirow{3}{*}{ Run \# } & \multirow{3}{*}{$\begin{array}{l}\text { Curve } \\
\text { section }\end{array}$} & \multirow{9}{*}{$\begin{array}{c}\text { Std Oil } \\
\text { Viscosity } \\
@ \\
29.2^{\circ} \mathrm{C} \text { is } \\
25.1 \mathrm{cP}\end{array}$} & \multicolumn{5}{|c|}{ Measured Viscosity @ $29.2^{\circ} \mathrm{C}$} \\
\hline & & & \multicolumn{3}{|c|}{ Bingham - Linear Fit } & \multicolumn{2}{|c|}{ Newtonian Fit } \\
\hline & & & $\begin{array}{l}\text { Viscosity } \\
\text { (cP) }\end{array}$ & $\begin{array}{l}\text { Off-set } \\
(\mathrm{Pa})\end{array}$ & $\mathrm{R}^{2}$ & $\begin{array}{l}\text { Viscosity } \\
\text { (cP) }\end{array}$ & $\mathrm{R}^{2}$ \\
\hline \multirow{2}{*}{1} & Up & & 24.3 & 1.44 & 0.9995 & 26.2 & 0.9925 \\
\hline & Down & & 24.4 & 1.04 & 0.9998 & 25.8 & 0.9954 \\
\hline \multirow{2}{*}{2} & Up & & 24.1 & 1.13 & 0.9992 & 25.6 & 0.9948 \\
\hline & Down & & 24.3 & 0.80 & 0.9997 & 25.4 & 0.9971 \\
\hline \multirow{2}{*}{3} & Up & & 24.0 & 1.40 & 0.9992 & 25.8 & 0.9924 \\
\hline & Down & & 24.2 & 0.96 & 0.9998 & 25.5 & 0.9960 \\
\hline
\end{tabular}

Table 5: Oil Standards Used

\begin{tabular}{|l|c|c|c|c|}
\hline Description & Expiration Date & Lot No. & Temperature $\left({ }^{\circ} \mathrm{C}\right)$ & Viscosity $(\mathrm{cP})$ \\
\hline \multirow{2}{*}{ S20 Cannon Standard } & \multirow{2}{*}{$12 / 31 / 02$} & \multirow{2}{*}{01301} & 25 & 29.27 \\
\cline { 4 - 5 } & & & 37.78 & 16.71 \\
\hline
\end{tabular}


Figure 1: Typical NIST Standard Oil Flow Curve - Low Shear Rate Range

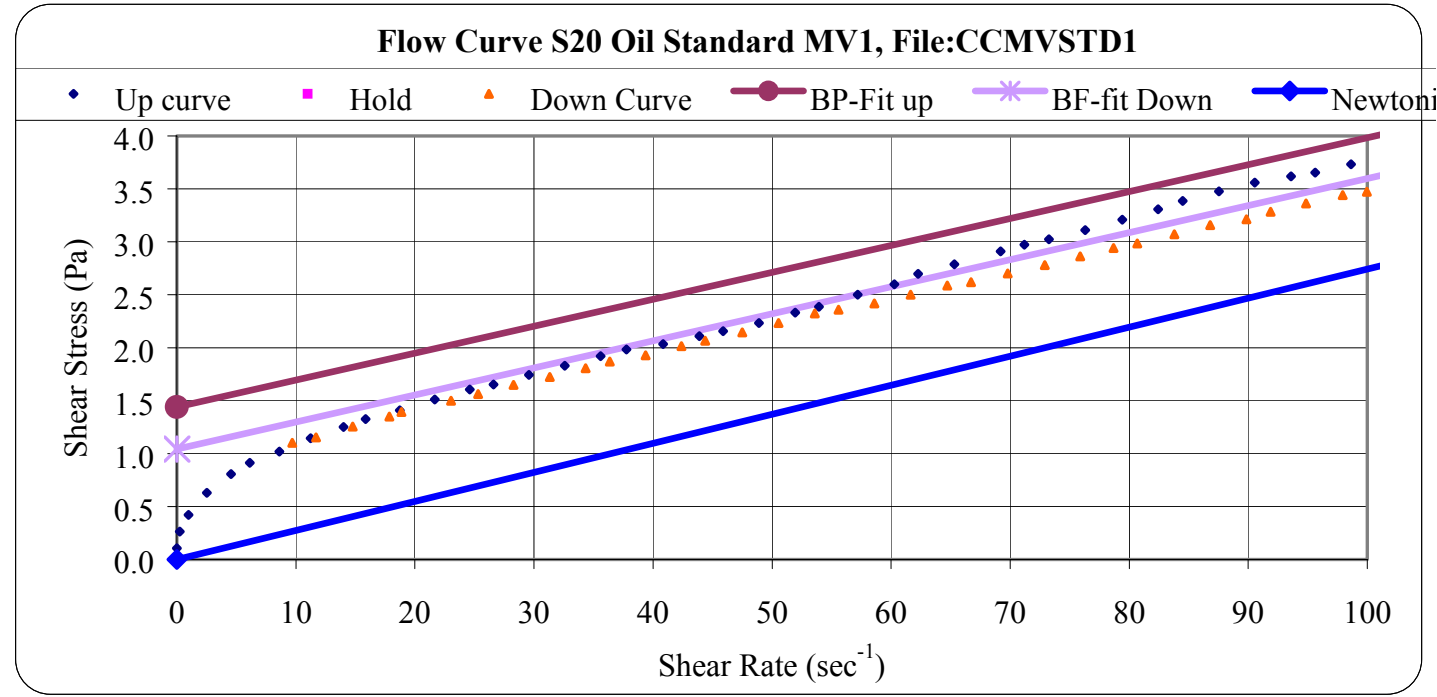

Figure 2: Typical NIST Standard Oil Flow Curve - Complete Flow Curve

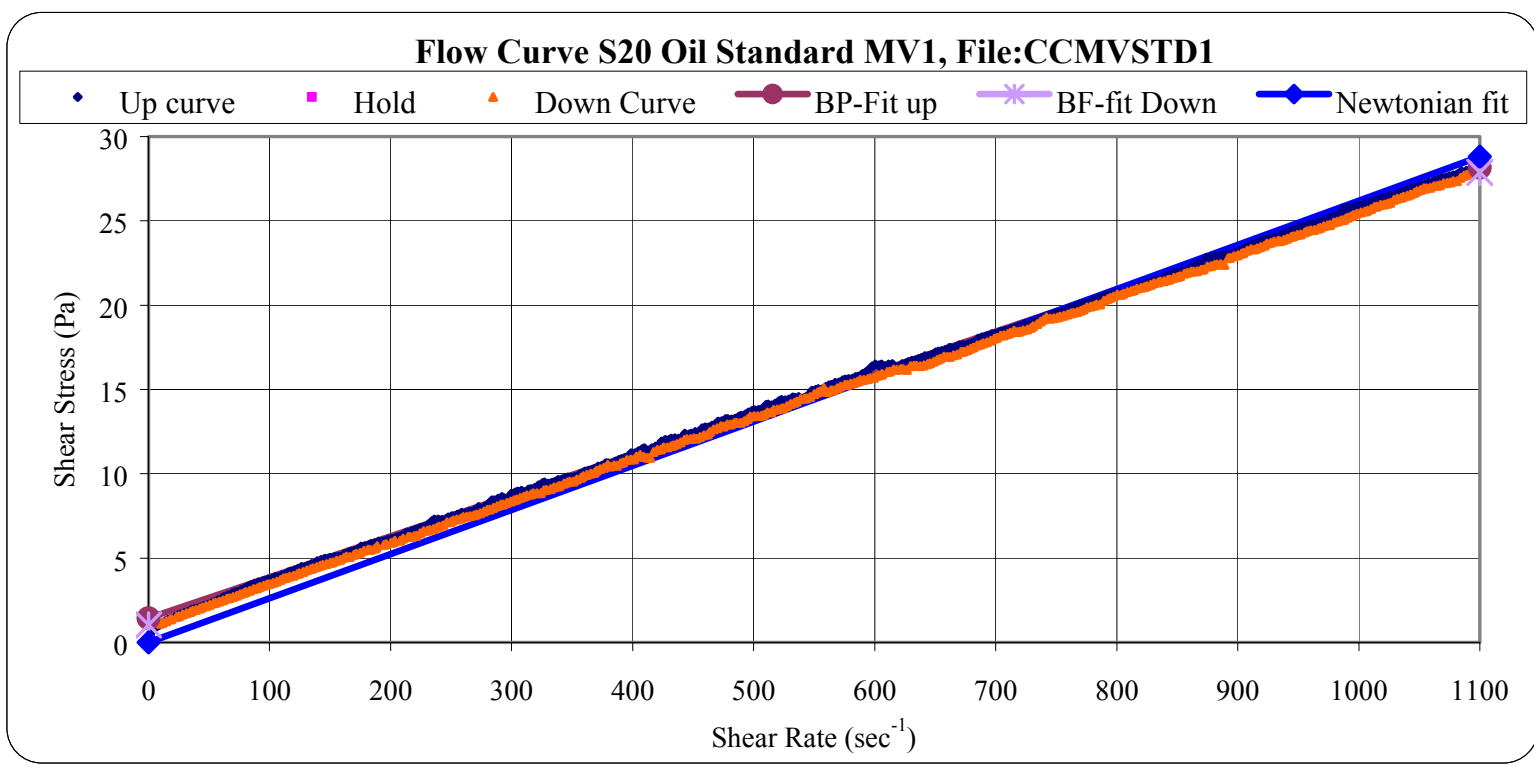

\section{AY-102 Sample}

Visual observation of the "as-received" AY-102 slurry sample indicates that it does not contain any yield stress at either $25^{\circ} \mathrm{C}$ or $40^{\circ} \mathrm{C}$. This statement is also supported by the fact the slurry was easily suspended and easily poured from its sample bottle and the slurry did not stick to the surfaces of the sample bottle, unlike HLW sludges that typically have yield stress. 
The flow curves and raw data are located in the attached "Radioactive AY-102, As-received FLOW CURVES" Excel spreadsheet as filenames shown in the Tables 6, 7 and 8. The sample was measured in triplicate for a given temperature and the results show that the curves are repeatable.

A representative sample flow curve is shown in Figure 3. There is a drop in the shear stress data around $625 \mathrm{sec}^{-1}$ and is typical of all the flow curves (both samples and NIST standards). This drop in data is a feature of the automatic decade shifting capabilities of this RV30 control unit, as the M5 measuring head approaches the decade changes $(1 \%, 10 \%$ for both the shear stress and shear rate). Also noted in Figure 3 that the shear stress data starts to deviate from a linear line as the shear rate increases, as though it is becoming dilatant. Because this fluid is very thin, it is highly suspected that this departure from a linear response is due to Taylor vortices, not due to dilatant behavior.

To determine when these secondary flow patterns (Taylor vortices) start to develop and what data to rejected, the following equation ${ }^{2}$ was used and is applicable to Newtonian fluids and can be used for judging non-Newtonian fluids. This equation is based on the Reynolds number of the fluid between the rotating inner bob and a stationary cup, at which the Taylor vortices start to become evident.

$$
\tau_{\text {reject }}<\frac{\rho \cdot\left(R_{O}-R_{i}\right)^{2.5}}{41.3 \cdot R_{i}^{0.5}} \cdot \dot{\gamma}_{i}^{2}
$$

where: $\tau_{\text {reject }}=$ observed shear stress $(\mathrm{Pa})$ to be rejected

$\rho=$ density of fluid $\left(\mathrm{kg}-\mathrm{m}^{-3}\right)$

$\mathrm{R}_{\mathrm{o}}=$ Cup radius $(\mathrm{m})$

$\mathrm{R}_{\mathrm{i}}=$ Bob radius $(\mathrm{m})$

$\dot{\gamma}_{i}=$ shear rate $\left(\mathrm{sec}^{-1}\right)$ at bob surface

The Taylor vortices curve, without any off-set, is shown in Figure 3 as the blue dots. Any data below the blue dots would be rejected for analysis, based on equation [3]. These results indicate that all the data should be accepted. 
Figure 3: AY-102 Flow Curve - Fitted and with Taylor Vortices Curve

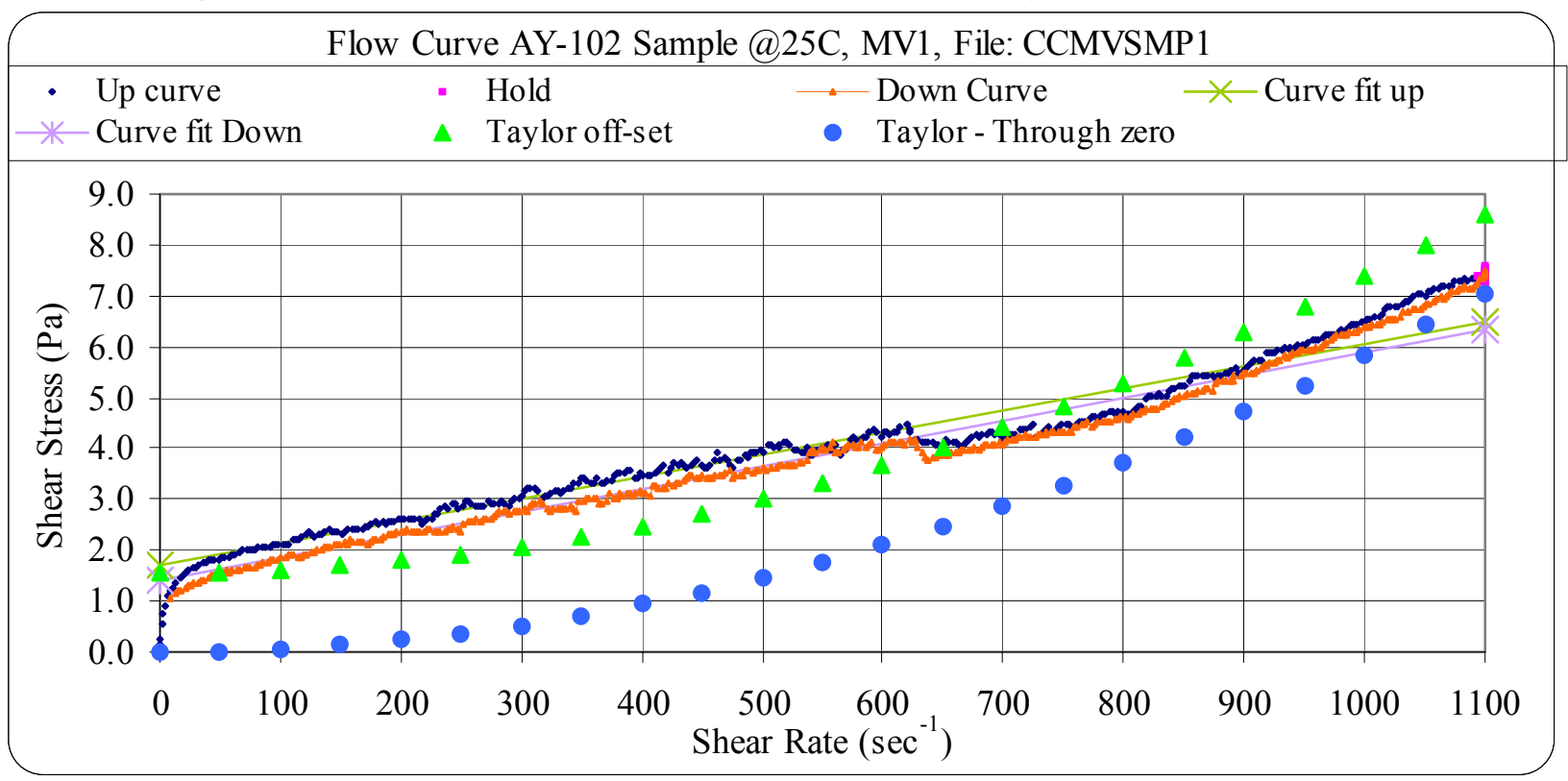

The apparent viscosity measurements of the raw data in the attached "Radioactive AY-102, As-received FLOW CURVES" excel spreadsheet were then calculated in the spreadsheet using equation [4].

$$
\eta=\frac{\tau}{\dot{\gamma}}
$$

where: $\eta=$ apparent viscosity or for Newtonian fluids the viscosity (cP)

To further determine if Taylor vortices were impacting the results, inspection of each data set was performed to determine at what shear rate does the apparent viscosity start to increase, indicating the onset of Taylor vortices. The shear rates at which the apparent viscosity starts to increase in each data set are shown in Table 6.

The shear stress at which Taylor vortices occur was then calculated using the shear rate data in Table 6 and equation [3]. The Newtonian viscosity was then calculated using equation [4] and the results are shown in Table 6 as calculated viscosity. The results in Table 6 are consistent for a given temperature and the average shear rate and viscosity were determined. 
Table 6: Shear Rate at Which an Increase in Apparent Viscosity is Detected in the AY-102 Flow Curves

\begin{tabular}{|c|c|c|c|c|c|c|}
\hline & \multicolumn{2}{|c|}{$\begin{array}{l}\text { Shear rate when apparent viscosity } \\
\text { increases }\left(\mathrm{sec}^{-1}\right) \text { in data sets }\end{array}$} & \multicolumn{2}{|c|}{$\begin{array}{c}\text { Calculated viscosity }(\mathrm{cP}) \\
\text { using equations [3] and [4] }\end{array}$} & \multicolumn{2}{|c|}{ Filename } \\
\hline & $25^{\circ} \mathrm{C}$ & $40^{\circ} \mathrm{C}$ & $25^{\circ} \mathrm{C}$ & $40^{\circ} \mathrm{C}$ & $25^{\circ} \mathrm{C}$ & $40^{\circ} \mathrm{C}$ \\
\hline \multirow{3}{*}{ Up curve } & 760 & 541 & 4.43 & 3.15 & Ccmvsmp1 & Ccmvsmp4 \\
\hline & 785 & 534 & 4.57 & 3.11 & Ccmvsmp2 & Ccmvsmp5 \\
\hline & 786 & 557 & 4.57 & 3.24 & Ccmvsmp3 & Ccmvsmp6 \\
\hline \multirow{3}{*}{ Down curve } & 803 & 535 & 4.68 & 3.11 & Ccmvsmp1 & Ccmvsmp4 \\
\hline & 767 & 537 & 4.47 & 3.12 & Ccmvsmp2 & Ccmvsmp5 \\
\hline & 784 & 550 & 4.56 & 3.20 & Ccmvsmp3 & Ccmvsmp6 \\
\hline Average & 781 & 542 & 4.55 & 3.16 & & \\
\hline
\end{tabular}

The shear rate data in Table 6 was then used to determine what part of the actual data set should be analyzed. Assuming that the data above the shear rate in Table 6 is due to Taylor vortices, then only the data below these shear rates would be analyzed. The $25^{\circ} \mathrm{C}$ data sets were fitted between 50 to $600 \mathrm{sec}^{-1}$, not from 0 to $780 \mathrm{sec}^{-1}$. The data below $50 \mathrm{sec}^{-1}$ was ignored because the data was very non-linear. The data between 600 to $780 \mathrm{sec}^{-1}$ was ignored due to the drop/shift in the data as described above. The $40^{\circ} \mathrm{C}$ data set were fitted between 50 to $550 \mathrm{sec}^{-1}$. Both the $25^{\circ} \mathrm{C}$ and $40^{\circ} \mathrm{C}$ data sets were fitted using equation [1] and the results are shown in Table 7 and Table 8 for the $25^{\circ} \mathrm{C}$ and $40^{\circ} \mathrm{C}$ data respectively.

Table 7: Results Using Equation [1] for the $25^{\circ} \mathrm{C}$ AY-102 Flow Curves

\begin{tabular}{|c|c|c|c|c|c|}
\hline \multirow{3}{*}{ Up curve } & Viscosity $(\mathrm{cP})$ & Off-set $(\mathrm{Pa})$ & $\mathrm{R}^{2}$ & Fitted Range $\left(\mathrm{sec}^{-1}\right)$ & Filename \\
\cline { 2 - 6 } & 4.34 & 1.73 & 0.9857 & $50-600$ & Ccmvsmp1 \\
\cline { 2 - 6 } & 4.28 & 1.54 & 0.9846 & $50-600$ & Ccmvsmp2 \\
\hline \multirow{3}{*}{ Down curve } & 4.15 & 1.54 & 0.9837 & $50-600$ & Ccmvsmp3 \\
\cline { 2 - 6 } & 4.51 & 1.39 & 0.9919 & $50-600$ & Ccmvsmp1 \\
\cline { 2 - 6 } & 4.31 & 1.32 & 0.9885 & $50-600$ & Ccmvsmp2 \\
\hline Average & 4.16 & 1.37 & 0.9914 & $50-600$ & Ccmvsmp3 \\
\hline
\end{tabular}

Table 8 Results Using Equation [1] for the $40^{\circ} \mathrm{C}$ AY-102 Flow Curves

\begin{tabular}{|c|c|c|c|c|c|}
\hline \multirow{3}{*}{ Up curve } & Viscosity $(\mathrm{cP})$ & Off-set $(\mathrm{Pa})$ & $\mathrm{R}^{2}$ & Fitted Range $\left(\mathrm{sec}^{-1}\right)$ & Filename \\
\cline { 2 - 6 } & 2.84 & 1.54 & 0.9798 & $50-550$ & Ccmvsmp4 \\
\cline { 2 - 6 } & 3.03 & 1.53 & 0.9719 & $50-550$ & Ccmvsmp5 \\
\hline \multirow{3}{*}{ Down curve } & 2.87 & 1.50 & 0.9719 & $50-550$ & Ccmvsmp6 \\
\cline { 2 - 6 } & 3.38 & 1.25 & 0.9817 & $50-550$ & Ccmvsmp4 \\
\cline { 2 - 6 } & 3.38 & 1.22 & 0.9864 & $50-550$ & Ccmvsmp5 \\
\hline Average & 3.27 & 1.25 & 0.9751 & $50-550$ & Ccmvsmp6 \\
\hline
\end{tabular}


The Taylor vortices is a phenomenon used to determine the viscosity of the fluid, in this case the sludge, with the results shown in Table 6. The results in Table 7 and Table 8, when fitted with equation [1] shows that the slurry has an off-set issue and that the viscosity of the linear line is approximately the same viscosity as that calculated by the onset of Taylor vortices as shown in Table 6. This information as well as visual observation of the sludge indicates that the sludge does not have any measurable yield stress.

Additionally, if this slurry is treated as a Bingham plastic (equation [1]), then the apparent viscosity at any shear rate, would be larger than that of the viscosity itself. This means that if the sludge had any yield stress, the onset of Taylor vortices would occur at a higher shear rate. For example, using the viscosity and off-set in Table 7 as the Bingham parameters, equating equations [1] and [3], the shear rate at the onset of Taylor vortices would occur in the MV1 head/MV cup at $995 \mathrm{sec}^{-1}$. If there were no yield stress, and using a viscosity of $4.3 \mathrm{cP}$, the onset of Taylor vortices is $740 \mathrm{sec}^{-1}$. The $740 \mathrm{sec}^{-1}$ is very close to where one first starts to observes Taylor vortices in the $25^{\circ} \mathrm{C}$ data sets (see Table 6), as where the $995 \mathrm{sec}^{-1}$ is well beyond the $1^{\text {st }}$ indication of Taylor vortices in the $25^{\circ} \mathrm{C}$ data sets. The same holds true for the $40^{\circ} \mathrm{C}$ data set. This observation further confirms that the sludge does not have a yield stress and can be treated as a Newtonian fluid.

The Taylor vortices curve was then modified by taking the average of the up and down curve off-set value, calling it $\tau_{\text {offset }}$ and adding it to equation [3]. The result is shown as equation [5].

$$
\tau_{\text {reject }, \text { mod }}<\tau_{\text {reject }}+\tau_{\text {offset }}
$$

The modified Taylor vortices curve was calculated using equation [5] and shown in Figure 2 as "Taylor off-set," which now shows data is being rejected, due to Taylor vortices.

Based on the Haake technical manuals, the acceptable minimal viscosity for the MV1 rotor, using the M5 torque/sensor package is $5 \mathrm{cP}$. This means any measured viscosity values below this limit are questionable. The results from the MV1 flow curves on the actual samples show a response to Taylor vortices, which provides some confidence that the reported viscosity values are acceptable.

\section{Vane Measurements:}

The selection of the Teflon ${ }^{\circledR}$ sample bottle to perform the vane measurements was due to the following:

- Sample bottle diameter was optimal, given quantity of sample provided for the rheology measurements.

- Amount of sample added and settle amount could easily be observed.

- Cup was ideal for remote operations. 
The A factor stated in Table 3 was used to only obtain the data. This data must be corrected, given the geometry of the vane, which is supplied in Table 3. The following equation is used calculate the appropriate A factor:

$$
A=\frac{2}{\pi \cdot D^{3} \cdot\left(\frac{H}{D}+\frac{1}{3}\right)} \cdot \frac{\Gamma_{\max }}{100 \%}
$$

where:

$$
\begin{aligned}
& A=\text { shear stress factor dependent on geometry }(\mathrm{Pa} / \% \text { torque }) \\
& D=\text { diameter of vane }(\mathrm{m}) \\
& H=\text { height of vane }(\mathrm{m}) \\
& \Gamma_{\max }=\text { maximum torque for M5 head }(0.049 \mathrm{~N}-\mathrm{m})
\end{aligned}
$$

The calculated A factor is $58.4 \mathrm{~Pa} / \%$ torque. The collected shear stress data was then corrected by multiplying it by 58.4 , since the A factor used in the Haake software during the measurements was $1 \mathrm{~Pa} / \%$ torque. The results are shown in Table 9 . For the $40^{\circ} \mathrm{C}$ measurements, there was no response from the instrument, indicating there was no measurable shear strength at $40^{\circ} \mathrm{C}$. During the $40^{\circ} \mathrm{C}$ measurements, the sample was capped, placed in an oven at $40^{\circ} \mathrm{C}$ for 48 hours, uncapped and the measurement performed. This was repeated two more times.

For the $25^{\circ} \mathrm{C}$ measurement, two of the three results showed no measured shear strength, while the last measurement had a maximum shear strength of $43 \mathrm{~Pa}$ and is shown in Figure 3 . The sample was treated the same as that in the $40^{\circ} \mathrm{C}$ measurement, but allowed to settle in the shield cells ambient temperature (around $25^{\circ} \mathrm{C}$ ). The last measurement is not typical of a material having shear strength using the vane geometry technique, hence questionable. To further dispute any measurable shear strength, Figure 4 shows the little residual sludge remaining on the vane after a shear strength measurement. The amount of material left on the vane is not typical for a sludge that has a yield stress of $43 \mathrm{~Pa}\left(430 \mathrm{dynes} / \mathrm{cm}^{2}\right)$.

Table 9: Shear Strength Results

\begin{tabular}{|c|c|c|}
\hline Temperature & Shear Strength $(\mathrm{Pa})$ & File \\
\hline $40^{\circ} \mathrm{C}$ & 0 & CCSMPVN1 \\
\hline $40^{\circ} \mathrm{C}$ & 0 & CCSMPVN2 \\
\hline $40^{\circ} \mathrm{C}$ & 0 & CCSMPVN3 \\
\hline $25^{\circ} \mathrm{C}$ & 0 & CCSMPVN4 \\
\hline $25^{\circ} \mathrm{C}$ & 0 & $* *$ \\
\hline $25^{\circ} \mathrm{C}$ & 43 & CCSMPVN6 \\
\hline
\end{tabular}

**Data file was lost due to computer failure after the completion of the run. Review of the data during the run indicated no shear stress was measured and is recorded as such in the $\log ^{3}$.

Figure 3: Shear Strength versus Time

\footnotetext{
${ }^{3}$ Fellinger, T.L., Notebook -“Rheology Tasks - Part 2", WSRC-NB-2000-00056 


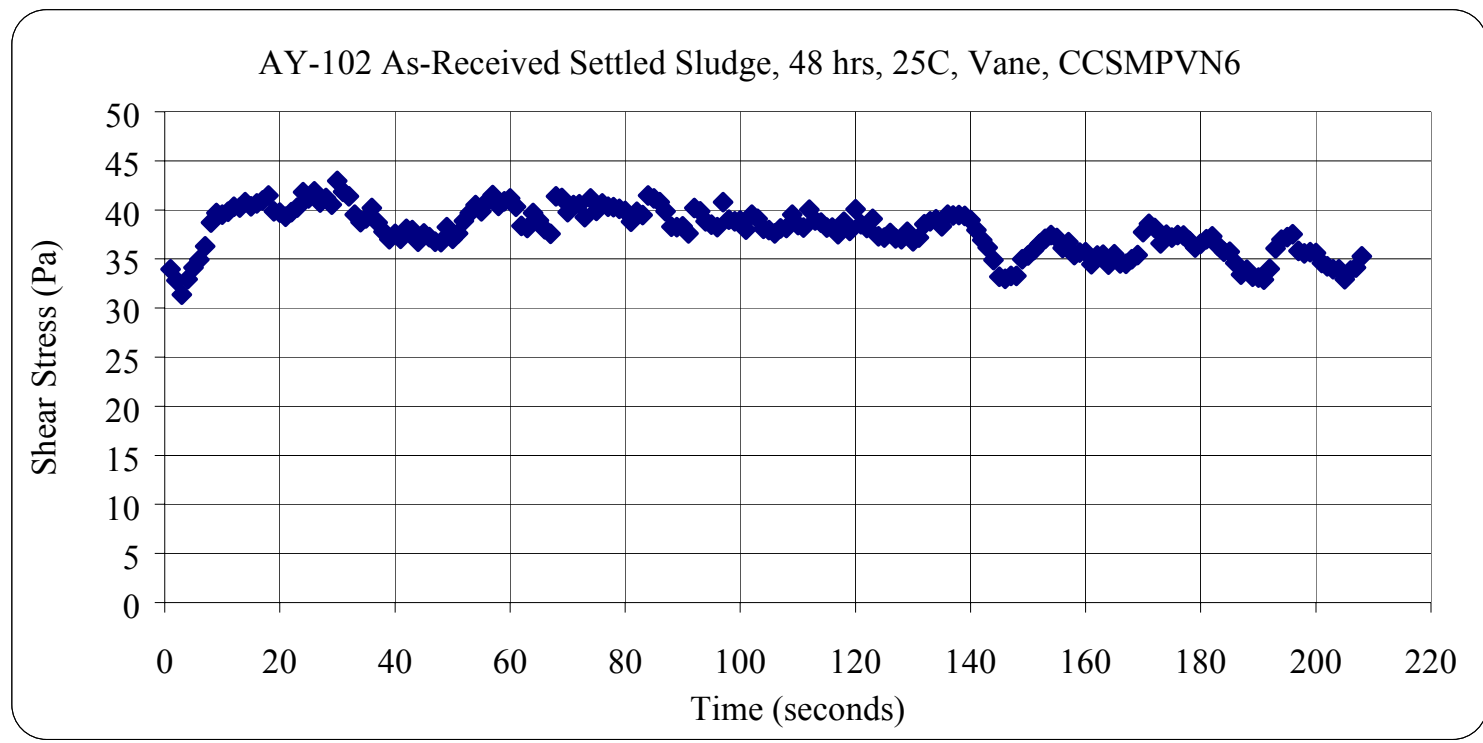

Figure 4: Vane with Residual Material after Completion of Vane Measurement

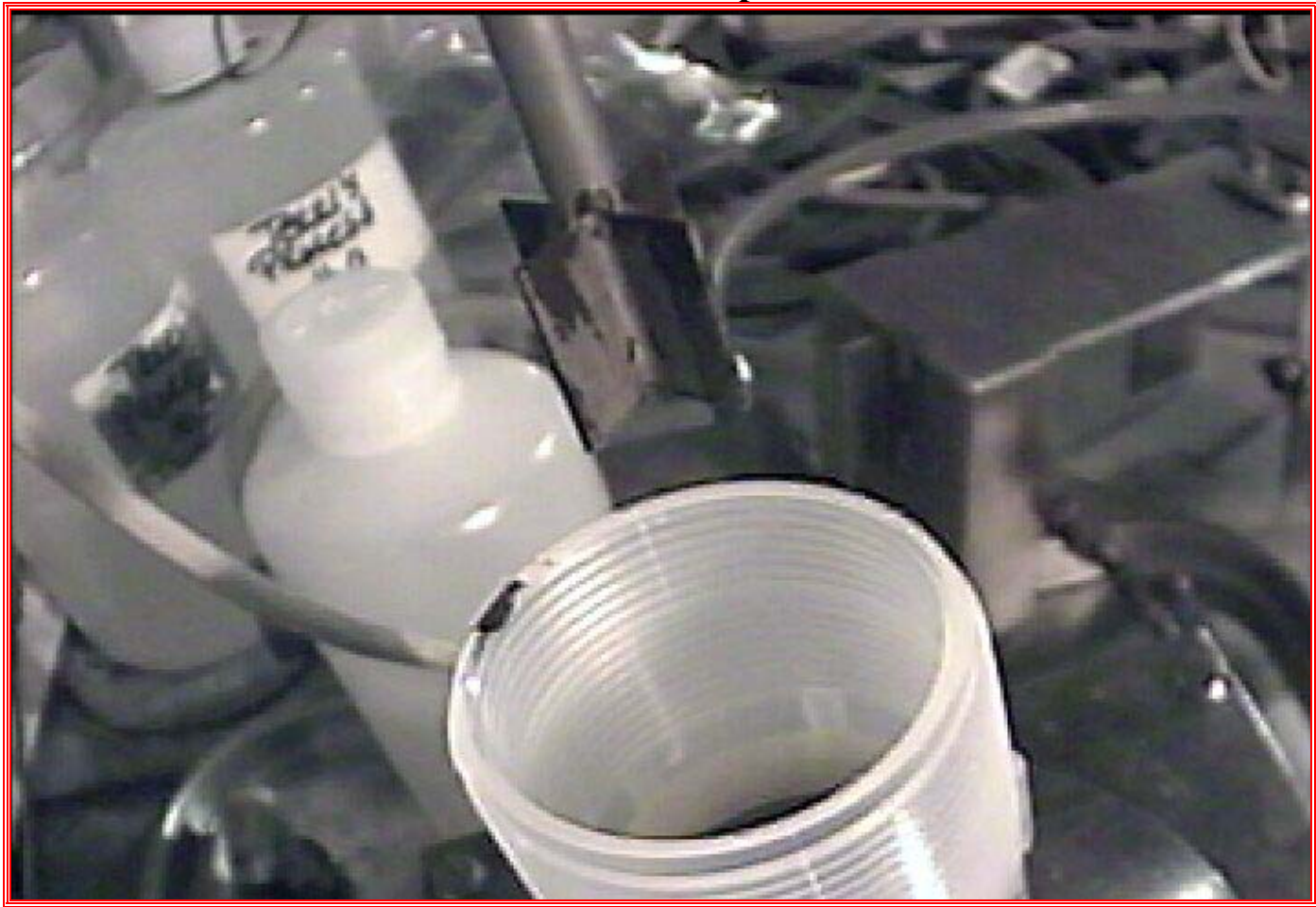




\section{CONCLUSIONS:}

The AY-102 “as-received” sludge:

- Visual inspection showed no signs of yield stress. Sludge was very fluid, did not stick to the sides of the sample bottle, and was easily suspended.

- Sludge flow curves measured at the same temperature were in good agreement with each other.

- All sludge flow curves were impacted by Taylor vortices.

- Analysis of the resulting flow curves show that the sludge is Newtonian in behavior with the viscosities reported in Table 7 and Table 8 . Inspecting the data to determine when the apparent viscosity started to increase and overlaying a Taylor vortices curve onto the flow curves supports this assessment. The combination of these assessments indicates that the sludge is Newtonian.

The AY-102 "settled" sludge:

- Shear strength measurements using a vane indicated that the settled sludge did not contain any measurable yield stress.

- All the shear strength measurements, except for one yielded no yield stress. One measurement at $25^{\circ} \mathrm{C}$ had a maximum stress of $43 \mathrm{~Pa}$, but the curve was not consistent of how a material with yield stress behaves.

- A photo (Figure 4) of the settled material after a vane measurement was not consistent with behavior for a material having yield stress. 


\section{APPENDIX C - \\ PARTICLE SIZE DETERMINATIONS OF AY-102/C-106 DRIED SLUDGE}

Ideally, a laser scattering technique would have been used to provide a true particle size measurement and distribution. Because of the high dose of 0.2-0.3 g of solid particles required for laser scattering techniques, the Contained Scanning Electron Microscope (CSEM) was used to measure the typical particle size. A disadvantage of this technique is that it is perform on a dry sample that can have the individual particles aggregate. However, the microscopist can discern aggregates from A large single particle and can measure the average particle size with good accuracy.

The microscopist mounted a small amount of dried sludge and selected a field that contained several average-sized particles. Micrograph \#1 contains two particles shown at 20X magnification, labeled as "Particle 1" and "Particle 2," that we chose to study. Micrographs \#2 and \#3 show increasing magnification of 250X and 1000X, respectively of Particle 1. Micrographs \#4 and \#5 show increasing magnification of 200X and 1000X magnification, respectively. The microscopist estimated that most of the particles were in the range of 1-10 micrometers.

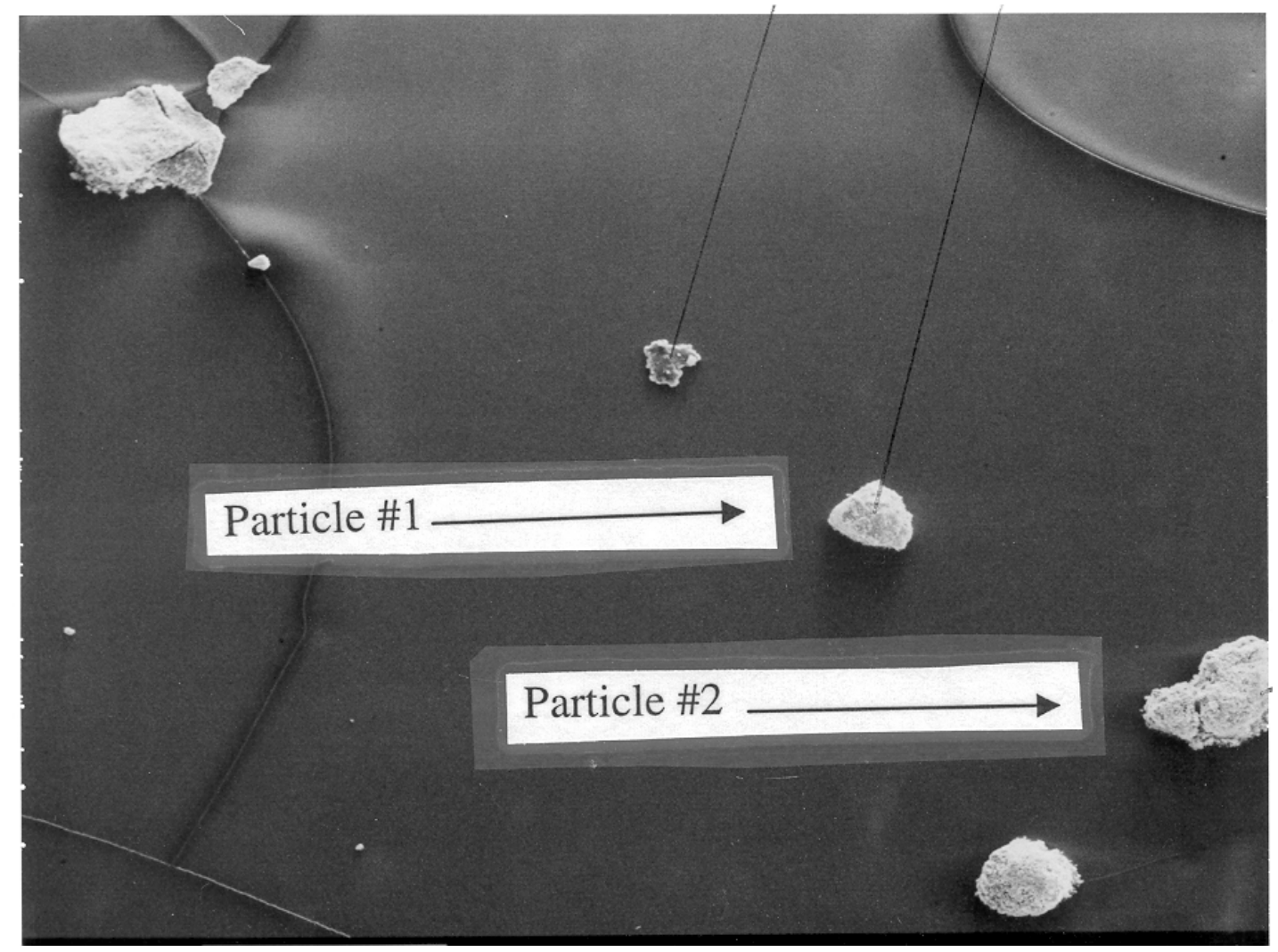

Micrograph \#1 


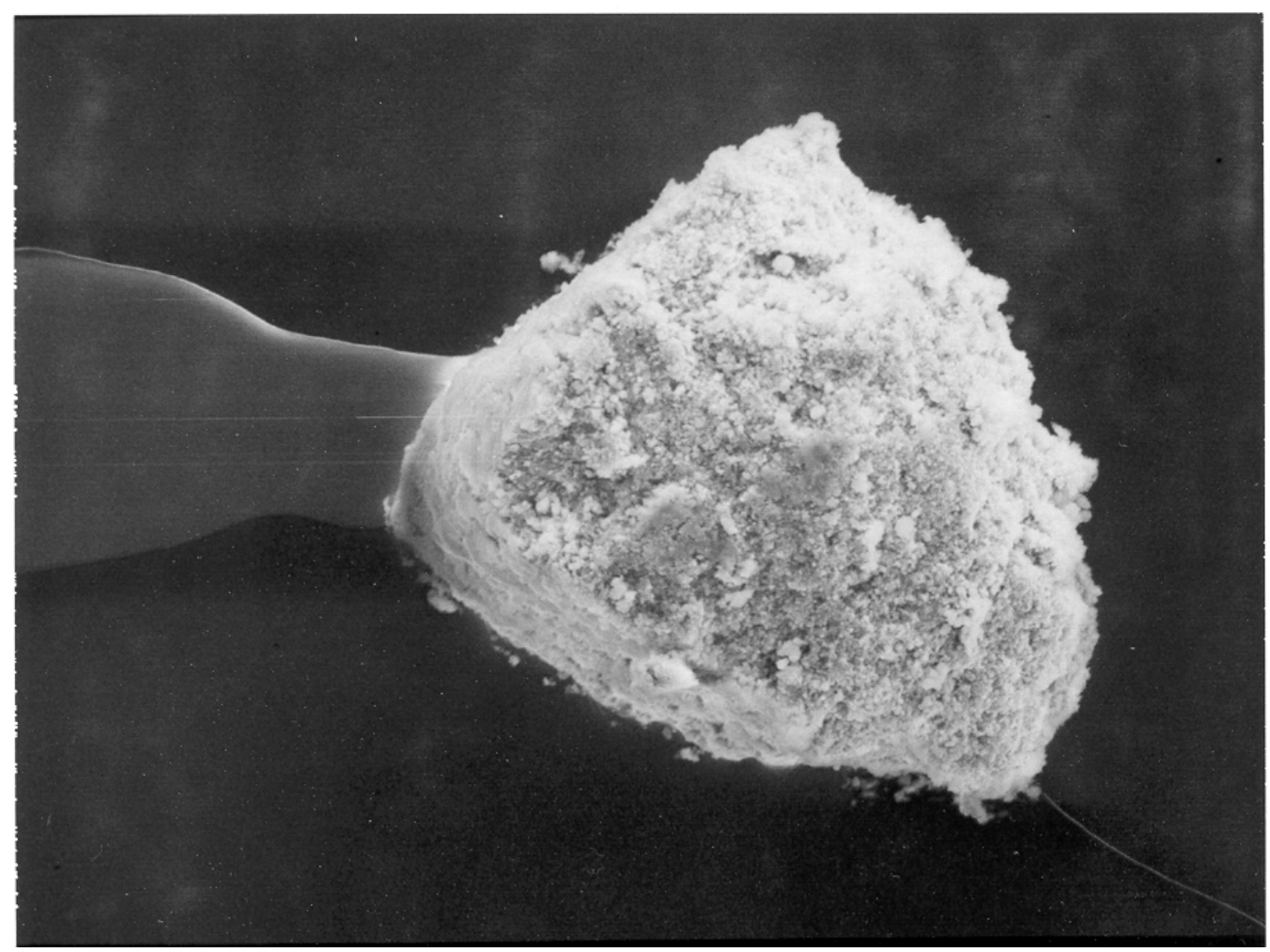

Micrograph \#2 - Particle 1 at 250X

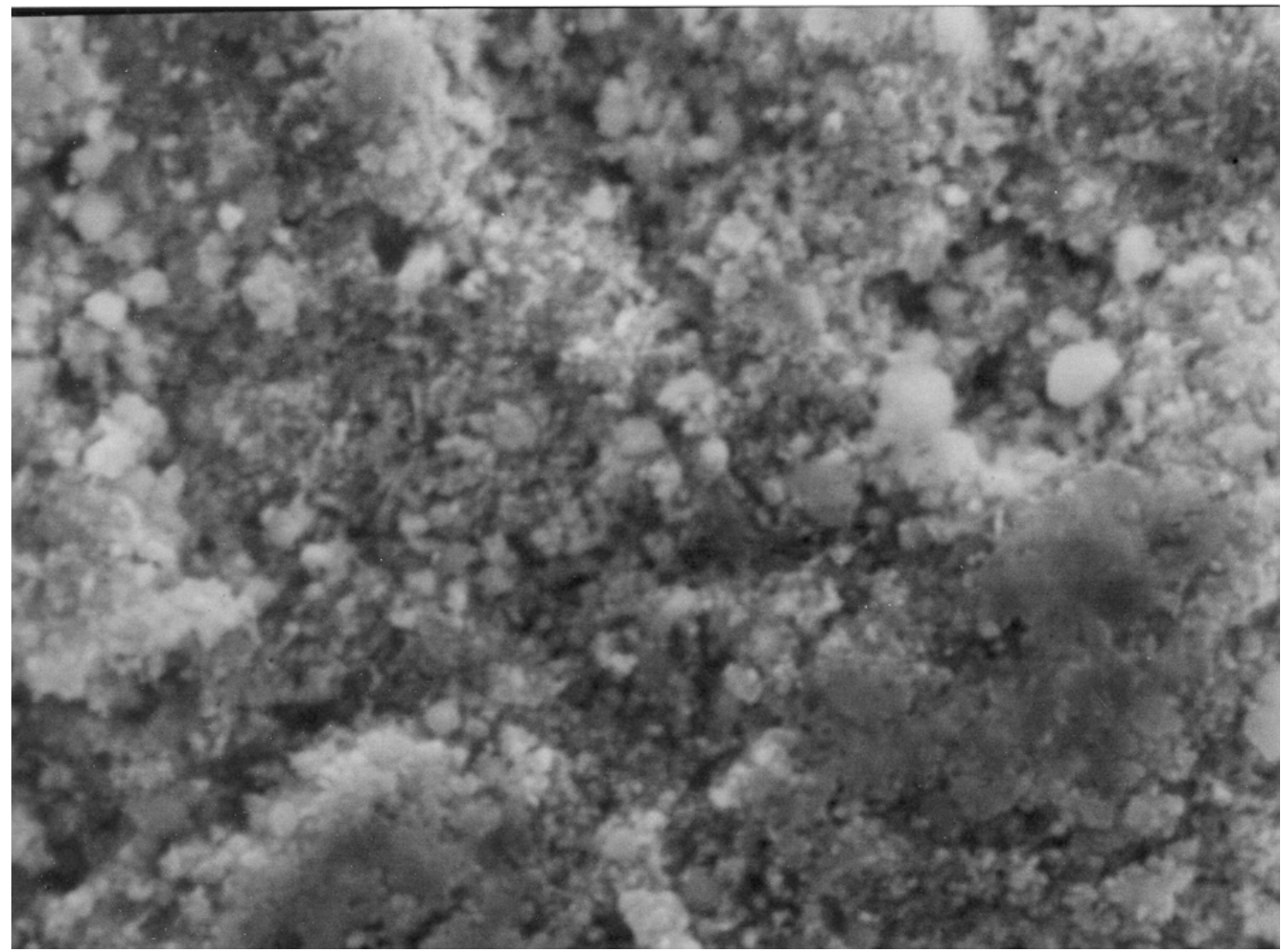

Micrograph \#3 - Particle 1 at 1000X 


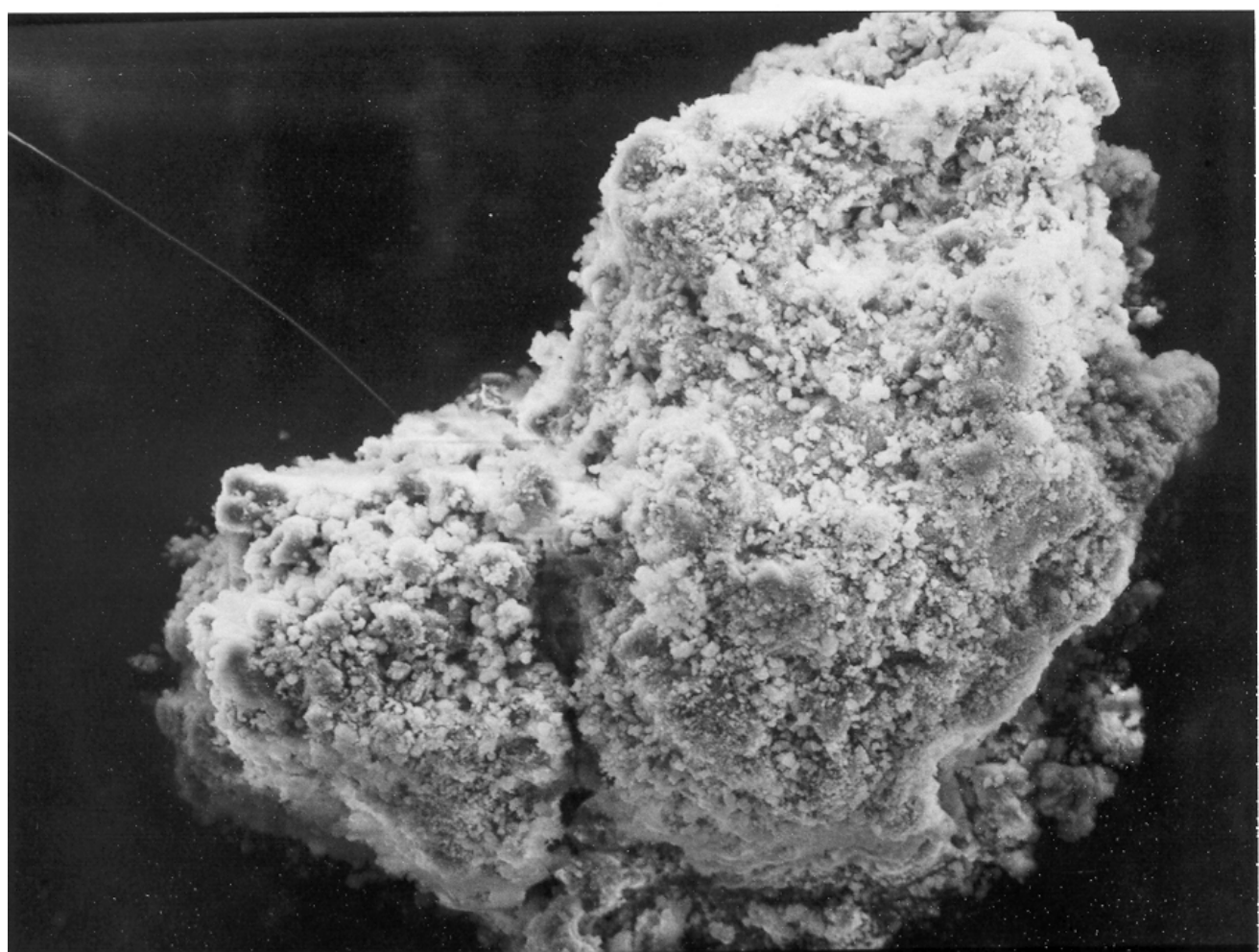

Micrograph \#3 - Particle 2 at 200X

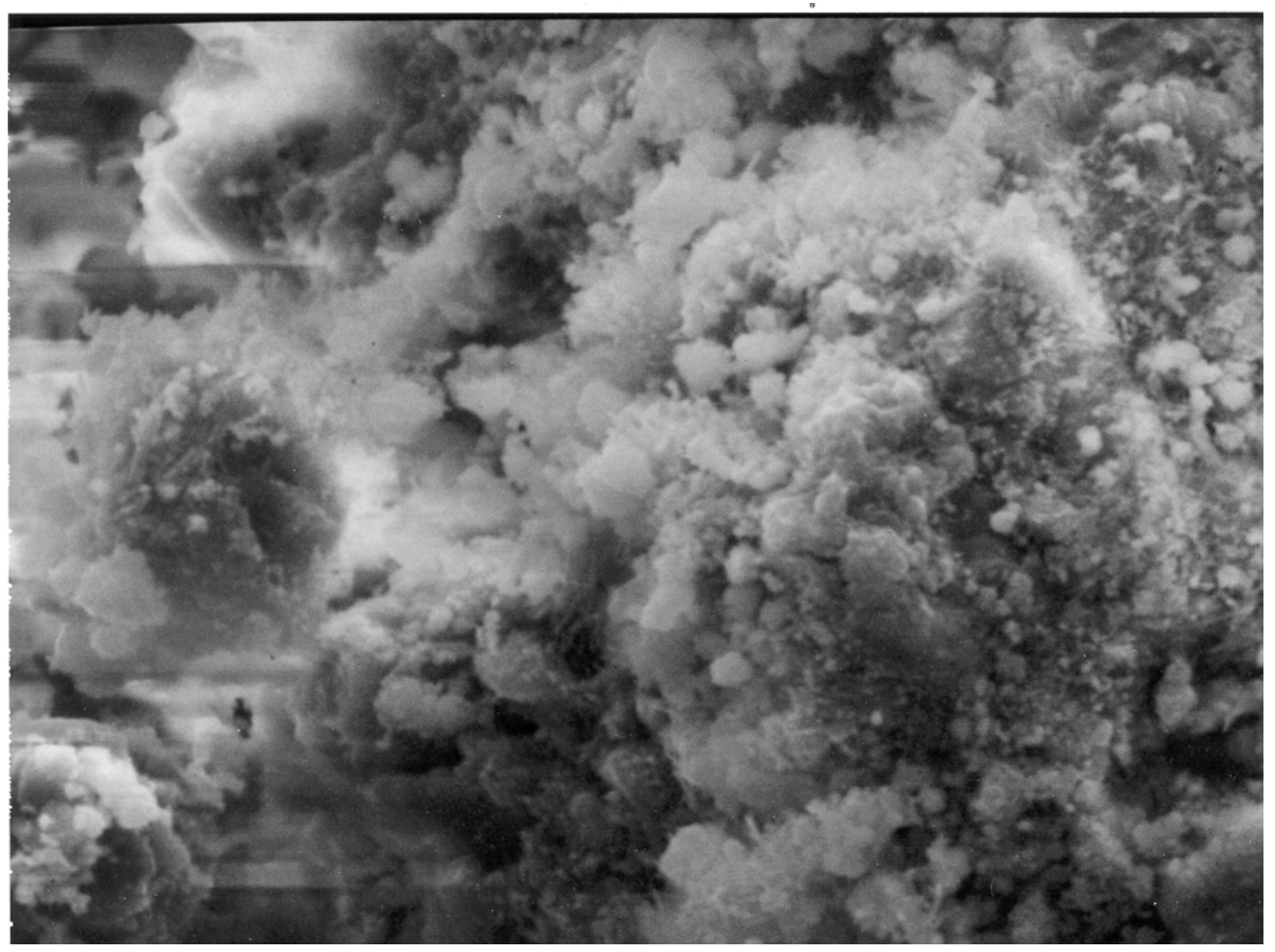

Micrograph \#5 - Particle 2 at 1000X 
This page intentionally left blank. 


\section{APPENDIX D - \\ CALORIMETRY MEASUREMENTS OF HEAT CAPACITY OF DRY AY-102/C-106 SOLID FRACTION}

Calorimetry measurements were made in the SRTC Shielded Cell Facility on the AY-102/ C-106 solid fraction that was dried prior to analysis. The procedure used for the measurements was ASTM E 1269-01 "Standard Test Method for Determining Specific Heat Capacity by Differential Scanning Calorimetry."

Figures D-1 through D-4 are plots of heat capacity in the units of $\mathrm{Cal} / \mathrm{g}{ }^{\circ} \mathrm{C}$ versus the temperature in ${ }^{\circ} \mathrm{C}$ that the heat capacity was measured. Figure D- 1 is a plot of heat capacity of water at various temperatures. Figures D-2, D-3, and D-4 are heat capacity plots of three subsamples of the dry sludge solids. A more expanded scale for the $\mathrm{Y}$-axis (heat capacity) for Figures D-2 and D-3, than for Figure D-4 explains the initial difference in appearance of the graphs. The scatter in the data was minimal, indicative of a homogeneous sub-sample of dried sludge. The average heat capacity was $0.686 \mathrm{Cal} / \mathrm{g}{ }^{\circ} \mathrm{C}$ which was converted to $\mathrm{J} / \mathrm{g}{ }^{\circ} \mathrm{C}$ by the conversion factor $1 \mathrm{Cal} .=4.187$ Joule to obtain the value of $2.872 \mathrm{~J} / \mathrm{g}{ }^{\circ} \mathrm{C}$ reported in Table $5-1$.

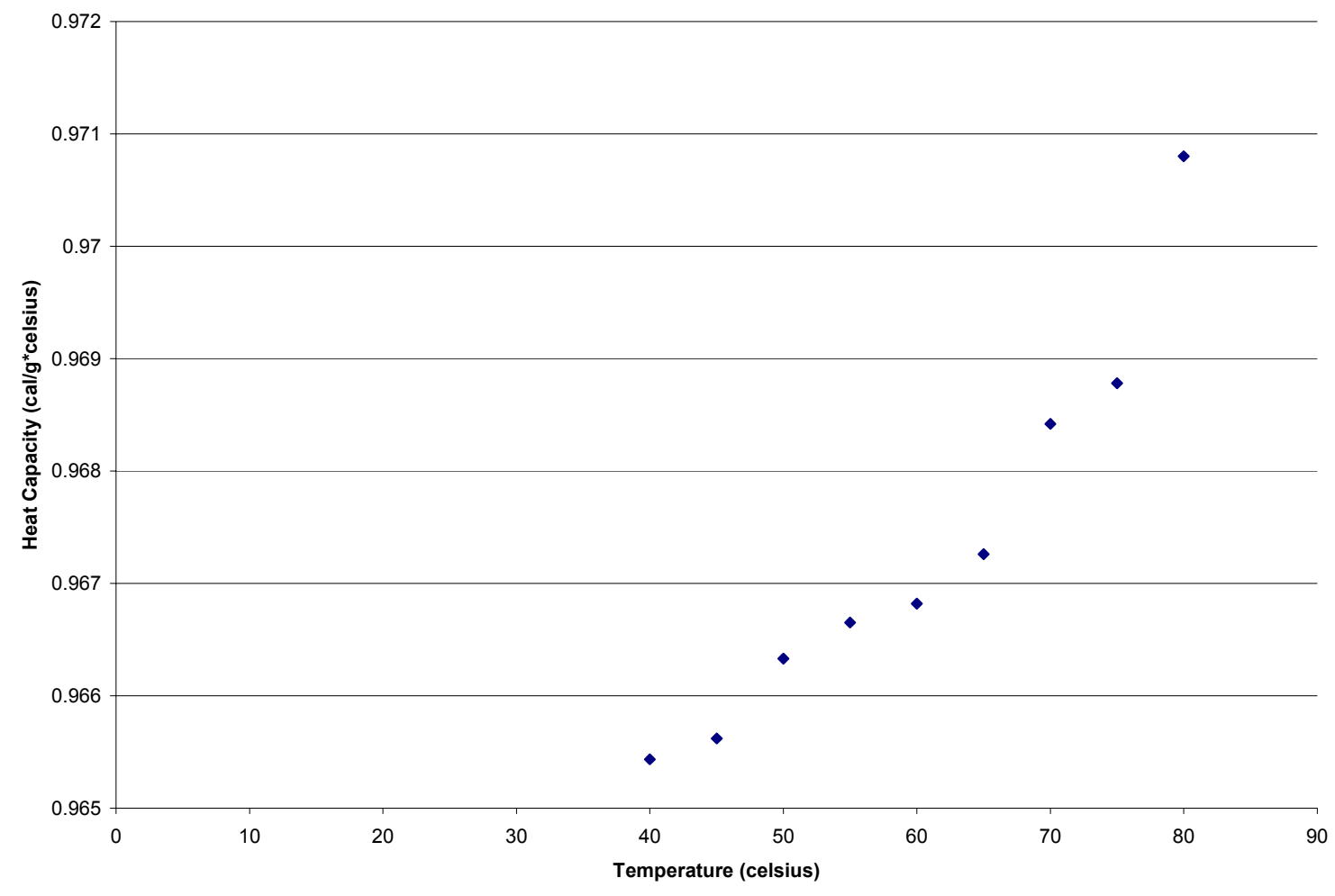

Figure D- 1. Heat Capacity in $\mathrm{Cal} / \mathrm{g}{ }^{\circ} \mathrm{C}$ vs. Temperature for Water Reference 


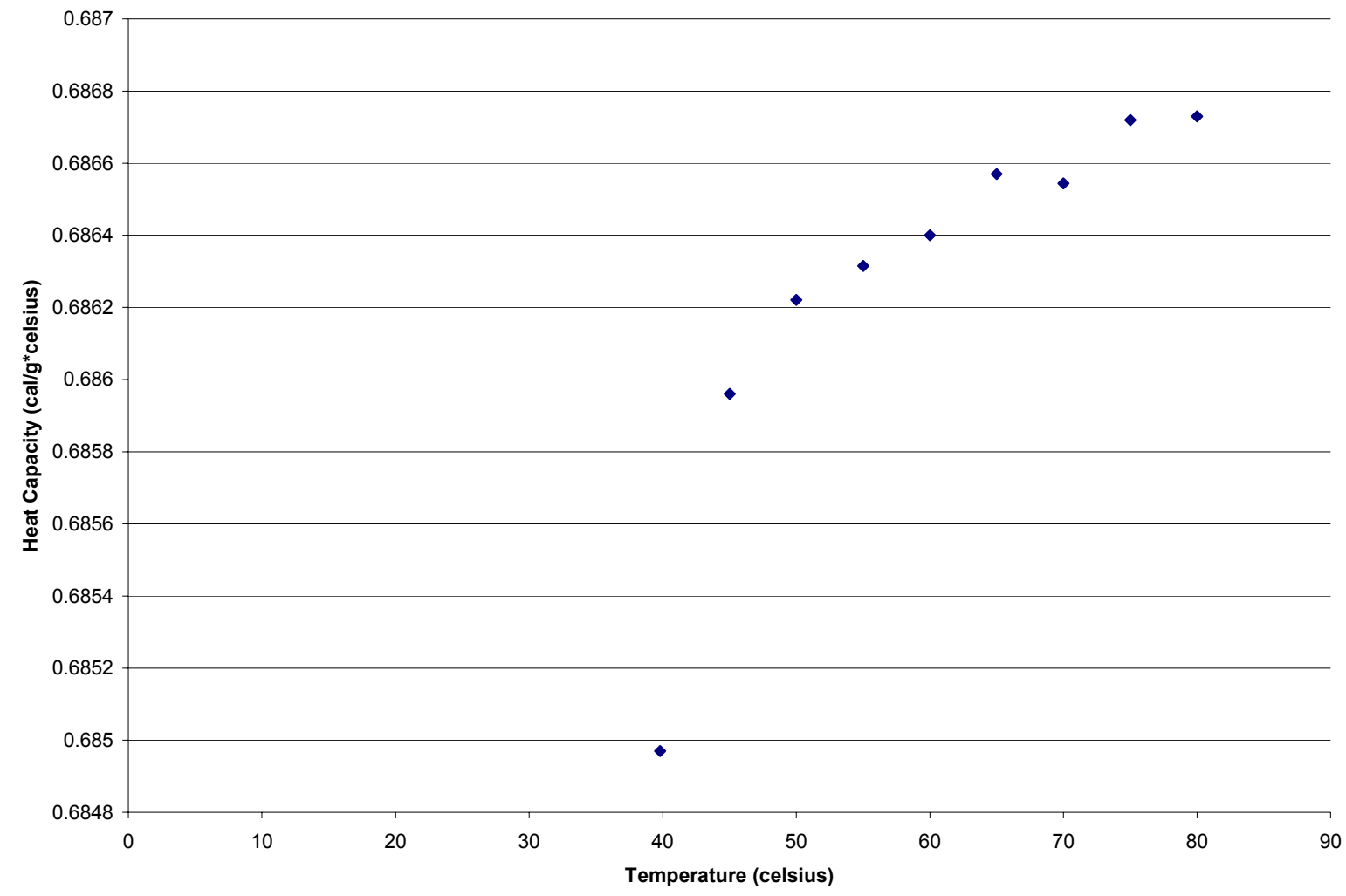

Figure D- 2. Trial 1 - Heat Capacity in $\mathrm{Cal} / \mathrm{g}{ }^{\circ} \mathrm{C}$ vs. Temperature for Dried AY-102/C-106 Solids 


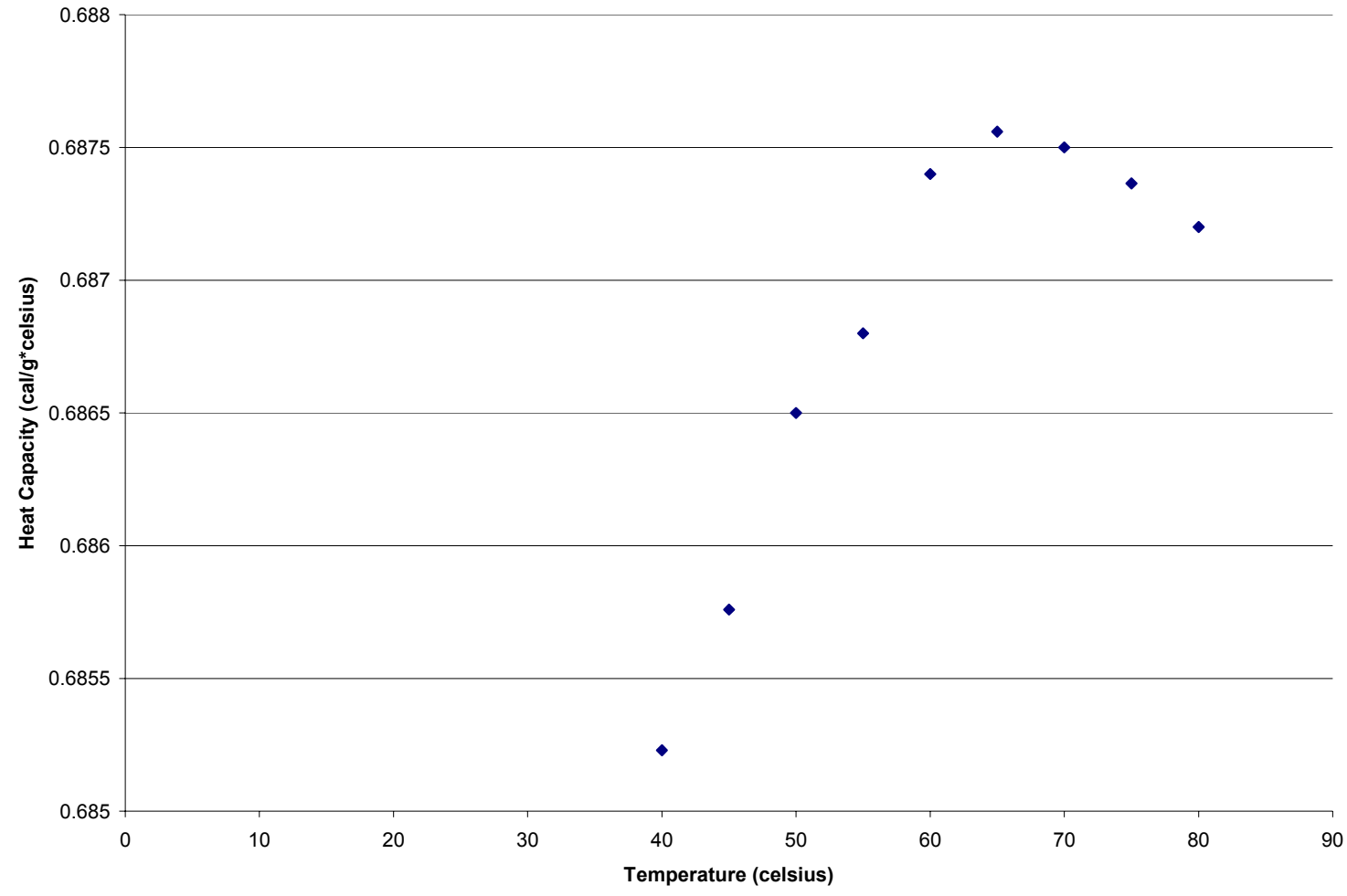

Figure D- 3. Trial 2 - Heat Capacity in $\mathrm{Cal} / \mathrm{g}{ }^{\circ} \mathrm{C}$ vs. Temperature for Dried AY-102/C-106 Solids 


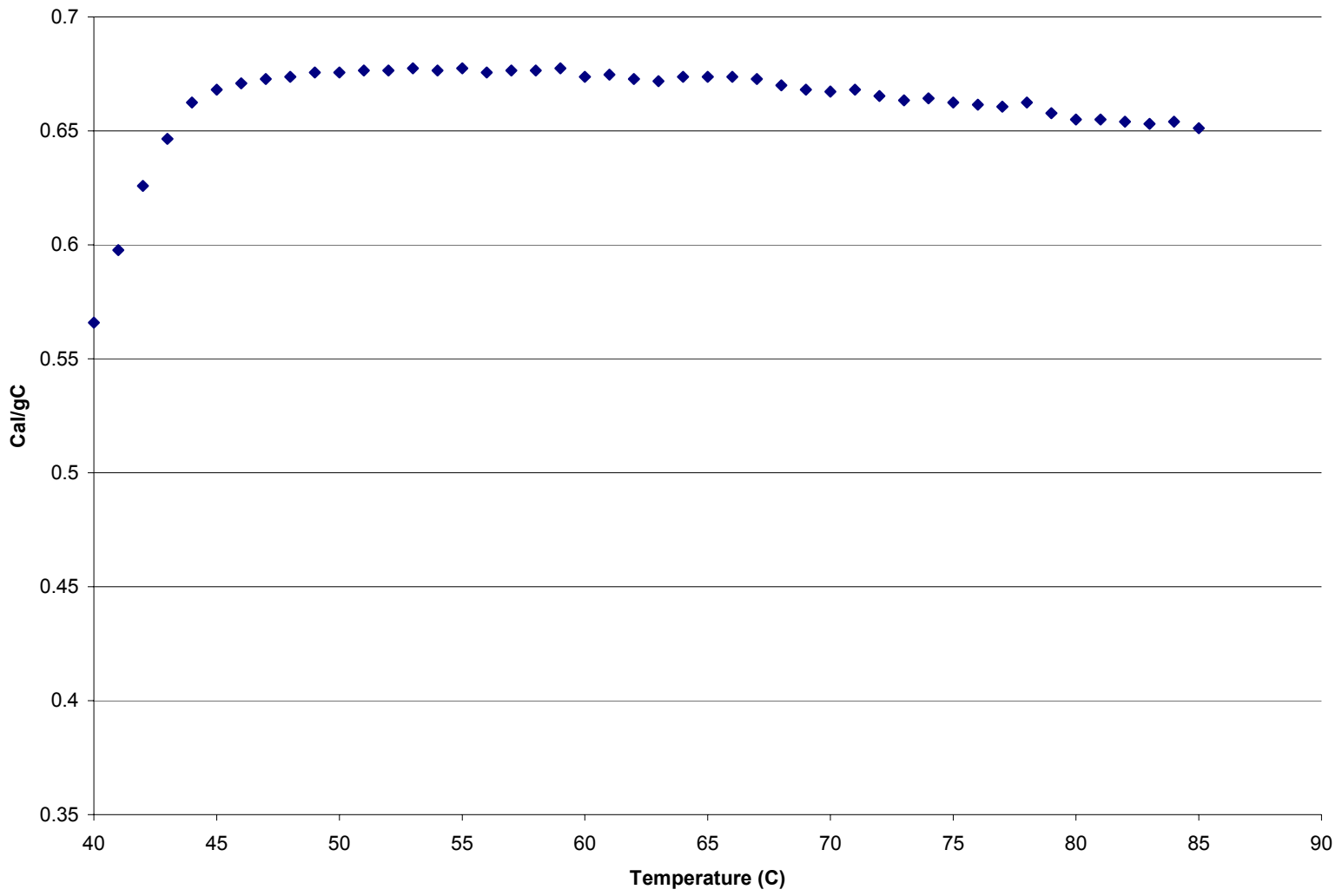

Figure D- 4. Trial 3 - Heat Capacity in $\mathrm{Cal} / \mathrm{g}^{\circ} \mathrm{C}$ vs. Temperature for Dried AY-102/C-106 Solids 